Uili norden

Nordiska ministerrådet

\title{
Lokal medvirkning for å nå 2010-målet om å stanse tap av biologisk mangfold
}

- et bidrag fra 14 nordiske kommuner

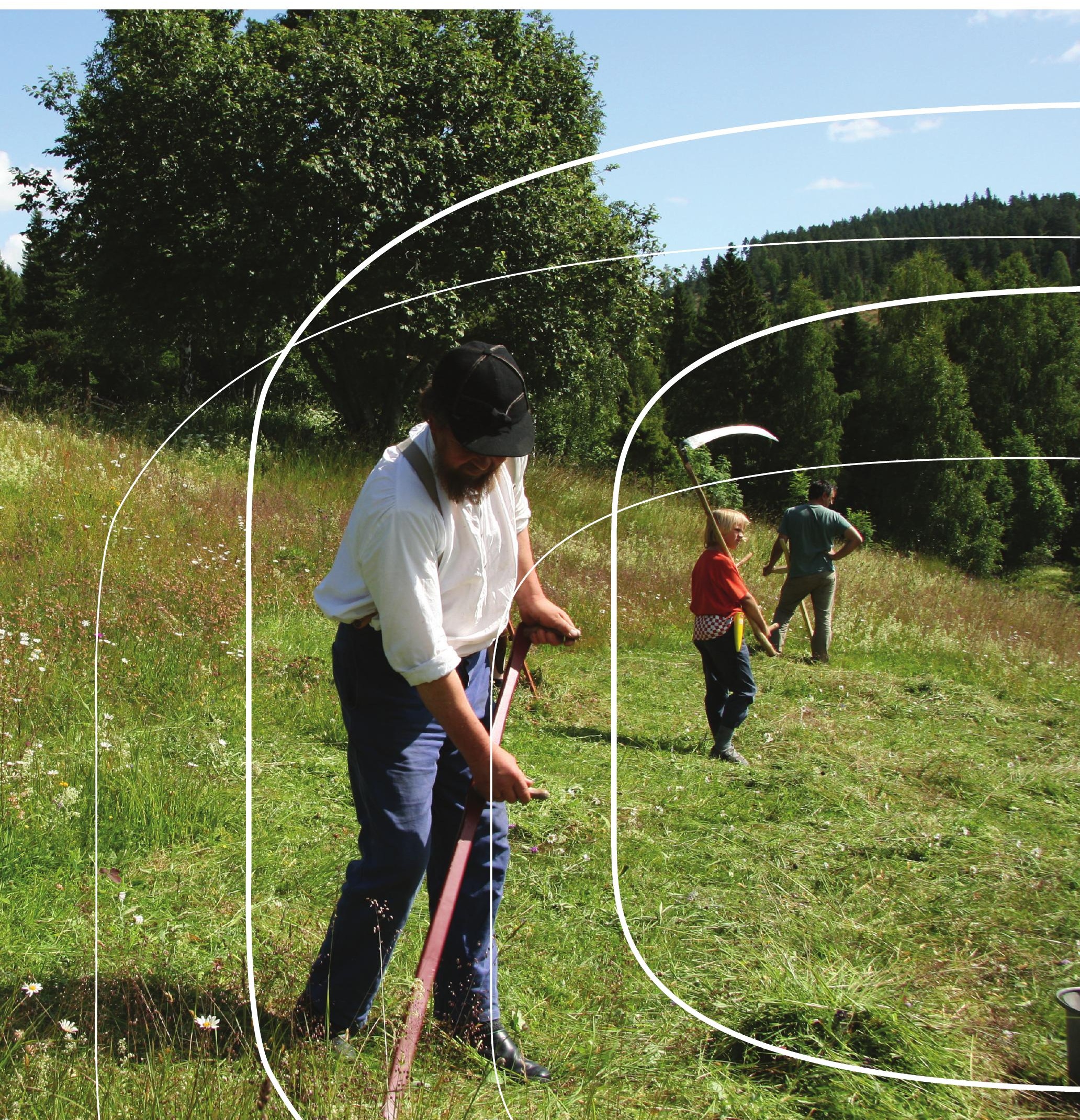


4 nordon 



\section{Lokal medvirkning for å nå 2010-målet om å stanse tap av biologisk mangfold}

- et bidrag fra 14 nordiske kommuner 
Lokal medvirkning for å nå 2010-målet om å stanse tap av biologisk mangfold

- et bidrag fra 14 nordiske kommuner

TemaNord 2010:602

(C) Nordisk ministerråd, København 2010

ISBN 978-92-893-2188-4

Trykk: Rosendahls Schultz Grafisk a/s

Omslagsfoto: Sissel Rübberdt

Opplag: 330

Trykt på miljøvennlig papir som oppfyller kravene i den nordiske miljøsvanemerkeordning.

Publikasjonen kan bestilles på www.norden.org/order. Flere publikasjoner på

www.norden.org/publikationer

Denne rapporten er gitt ut med finansiell støtte fra Nordisk ministerråd. Innholdet i rapporten avspeiler imidlertid ikke nødvendigvis Nordisk ministerråds synspunkter, holdninger eller anbefalinger.

Printed in Denmark

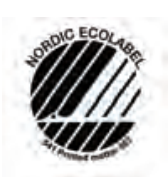

Nordisk ministerråd

Ved Stranden 18

DK-1061 København K

Telefon (+45) 33960200

Nordisk råd

Ved Stranden 18

DK-1061 København K

Fax (+45) 33960202

Telefon (+45) 33960400

Fax (+45) 33111870

www.norden.org

\section{Det nordiske samarbeidet}

Det nordiske samarbeid er en av verdens mest omfattende regionale samarbeidsformer. Samarbeidet omfatter Danmark, Finland, Island, Norge og Sverige, samt de selvstyrende områdene Færøyene, Grønland og Åland.

Det nordiske samarbeid er både politisk, økonomisk og kulturelt forankret, og er en viktig medspiller i det europeiske og internasjonale samarbeid. Det nordiske fellesskap arbeider for et sterkt Norden i et sterkt Europa.

Det nordiske samarbeid ønsker å styrke nordiske og regionale interesser og verdier i en global omverden. Felles verdier landene imellom er med til å styrke Nordens posisjon som en av verdens mest innovative og konkurransekraftige regioner. 


\section{Innhold}

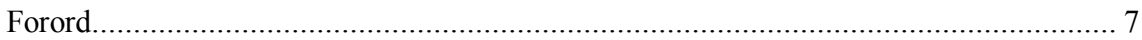

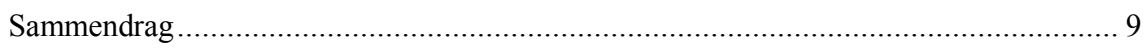

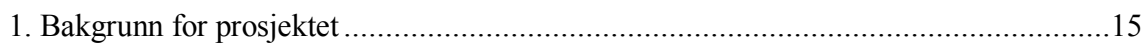

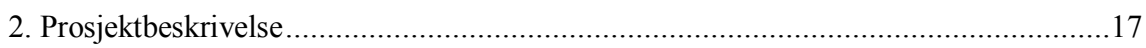

3. Succéfaktorer - noen erfaringer og rekommandasjoner fra kommunene i prosjektet .....19

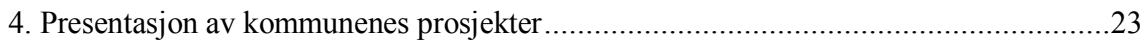

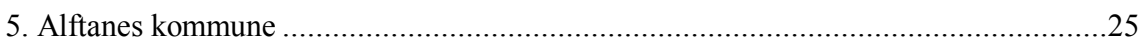

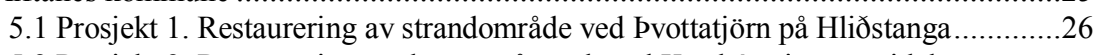

5.2 Prosjekt 2. Restaurering av drenert våtmark ved Kasthúsatjörn, utvidelse av vernområdet $\mathrm{g}$ forbedring av hekkeplasser. ........................................22

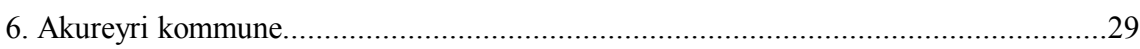

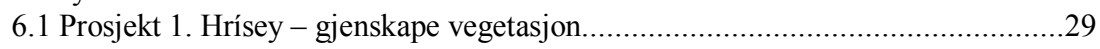

6.2 Prosjekt 2. Glerárdalur - gjenskape vegetasjon ................................................30

6.3 Prosjekt 3. Naustaborgir - restaurering av våtområde for fuglelivet ....................31

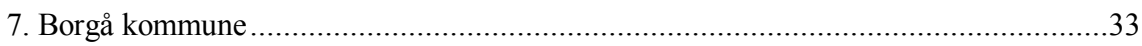

7.1 Projekt 1: Inrättande av nationalstadsparken i Borgå ........................................33

7.2 Projekt 2. Vård av ängslandskapet vid Marens äng............................................35

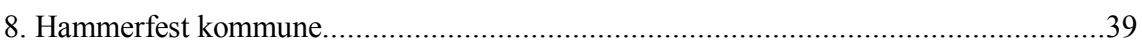

8.1 Prosjekt 1. Utsetting av kunstige rev på havbunnen..........................................39

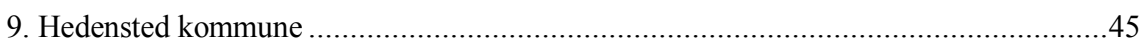

9.1 Prosjekt 1. Restaurering af Skjold Å og etablering af vådområde omkring Skjold $\AA$. .........................................................................45

9.2 Prosjekt 2. Sikring af græsningsdrift/høslæt på de 30 botanisk mest værdifulde eng- og overdrevsarealer i Hedensted Kommune ................52

9.3 Prosjekt 3. Certificering af skove nord for Vejle Fjord ........................................55

9.4 Prosjekt 4. Den Klimatilpassede Kommuneplan for Hedensted Kommune ...........57

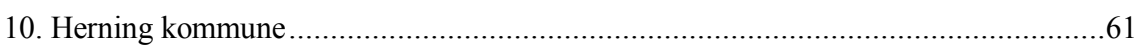

10.1 Projekt 1. Naturpolitik i Herning Kommune...................................................61

10.2 Projekt 2. Laksehandlingsplan i Skjern $\AA$-systemet ........................................65

10.3 Projekt 3. Klimainnsats i Herning kommune ..................................................68

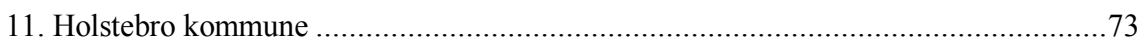

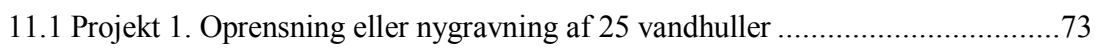

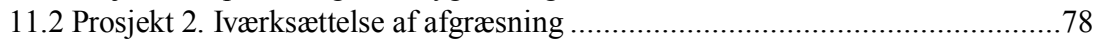

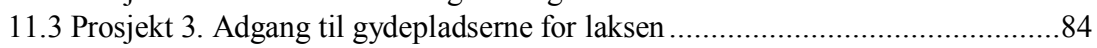

12. Kolding kommune ..................................................................................... 91

12.1 Prosjekt 1. Skærsø, Nørremose og Husted Mose - genopretning af sø og tilhørende moseområder.........................................................................91

12.2 Prosjekt 2. Åkær $\AA$ - genopretning af vandløb og etablering af vådområder........96

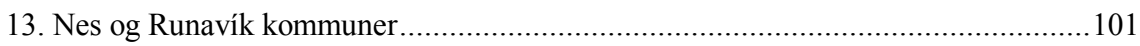

13.1 Projekt 1: Toftavatn - Natur, oplevelser og trivsel.........................................101

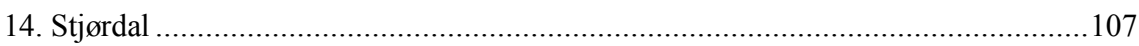

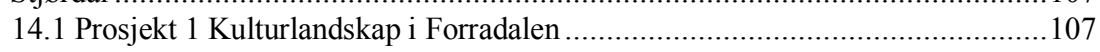

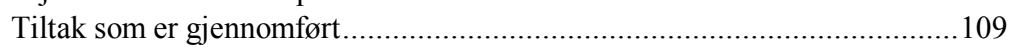

14.2 Prosjekt 2. Regulering av vannmiljø og mulige tiltak i gamle elveløpet Halsøen, Langøra og Stjørdal havn.......................................................112 
15. Trondheim kommune

15.1 Prosjekt 1. Gjenåpnet av Ilabekken - restaurering av biologisk

mangfold i en urban bekk

15.2 Prosjekt 2. Forvaltning av kulturlandskapet på Lian - Solem - skjøtsel og restaurering for å ivareta biologisk mangfold

15.3 Prosjekt 3. Sårbare viltarter i Trondheim bymark - skjøtsel og restaurering for å ivareta biologisk mangfold

16. Vanda kommune............ 131

16.1 Den biologiska mångfalden i Vanda........................................................ 131

16.2 Projekt 1. Kommunal generalplan som verktyg vid bevarandet av naturens

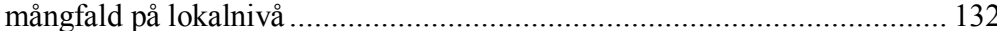

16.3 Projekt 2. Förnyandet av Vanda stads principer för skogsvård.

16.4 Projekt 3. Utveckling av natur- och rekreationsområdet Petikko med beaktande av naturens mångfald

17. Ørebro kommune

141

17.1 Från bakgård till naturreservat ............................................................. 141

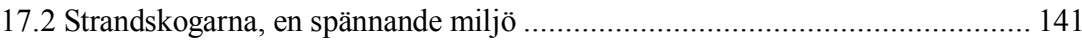

17.3 Vassarna och de grunda vikarna................................................................ 141

17.4 Beteslandskapet och blomsterängarna ...................................................... 142

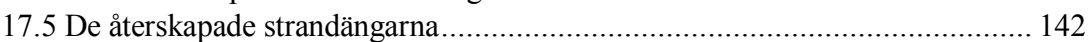

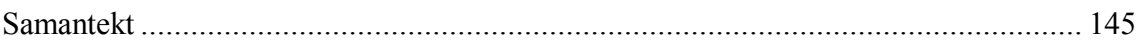

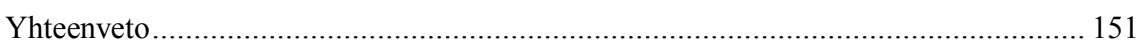

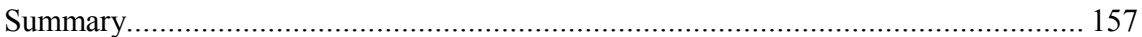




\section{Forord}

Prosjektets mål er å vise viktigheten av en lokal innsats i arbeidet med å bevare det biologiske mangfoldet. Prosjektet har vært finansiert av Nordisk Ministerråd, men prosjektgruppens medlemmer har også lagt inn en betydelig egeninnsats. Kommunene har selv for egne midler gjennomført de prosjektene som beskrives i rapporten.

Ved oppstart av prosjektet ble det opprettet en prosjektgruppe med representanter fra de deltagende nordiske landene.

Prosjektet har vært ledet av Direktoratet for naturforvaltning, Norge, ved leder av prosjektgruppen Terje Klokk. Prosjektet har også knyttet til seg prosjektmedarbeidere i prosjektperioden.

Prosjektgruppens deltagere har vært: Terje Klokk, (leder), Norge, Eva Juul Jensen, Danmark, Stefan Skog, Finland, Sune Sohlberg, Sverige, Bergmann Finnsson, Farøyene, Arni Bragasson (2006-08), Trausti Baldursson (2008-09), Hjalti Gudmunsson (2009-10), Island.

Følgende personer har vært prosjektmedarbeidere i prosjektperioden; Jenny Selnes, Ingvild Kalland, Lars Ekker, Hege Husby Talsnes og Lise Grønning Michalsen.

Vi håper at prosjektene som presenteres kan motivere andre kommuner til å starte opp og gjennomføre prosjekter som ivaretar det biologiske mangfoldet i sin kommune.

Direktoratet for naturforvaltning

Yngve Svarte

avdelingsdirektør
Terje Klokk

leder prosjektgruppen 



\section{Sammendrag}

Dette nordiske prosjektet demonstrerer viktigheten av å ta vare på det biologiske mangfoldet på det lokale plan og kommunenes viktige rolle som arealforvaltere. De 30 lokale prosjektene som beskrives viser at det er mulig å gjennomføre viktige prosjekter som ivaretar biodiversitet.

Prosjektene som beskrives i rapporten er mangoldige, fra rene bevaringsprosjekter til restaurering, kommunale planer og bekjempelse av fremmede arter. Nedenfor følger en kort sammenfatning av de prosjektene som kommune rapporterer.

\section{Akureyri}

En tidligere søppelplass ved inngangen til Glerárdalur friluftsområde har blitt ryddet. Det skal sås frø fra den islandske flora for å gjenskape vegetasjonsdekket. På denne måten vil områdets landskapstrekk falle naturlig inn i resten av området.

På øya Hrisey har de fremmede artene hundekjeks (Anthriscus sylvestris), sandlupin (Lupinus nootakensis) tatt overhånd og utgjør i dag 11$13 \%$ av øya. Området med fremmede arter slås med jevne mellomrom og det såes frø fra islandsk flora for å gjenskape det biologiske mangfoldet.

Naustaborgir er en del av friluftsområdet nord for Akureyri. Tidligere var dette et landbruksområde og ble derfor ryddet og drenert. For å skape bedre betingelser for et naturlig rikt fugleliv har grøftene blitt lukket. Naturlig tilsig av vann samles som før i tiden og har dannet et tjern. Området har også blitt gjort mer tilgjengelig for allmennheten.

\section{Alftanes}

Et tidligere drenert våtmarksområde restaureres og ferdsel reguleres. Informasjon om hvor viktig det er at fuglene ikke forstyrres i hekketiden skal også settes opp. Det ubebygde arealet rundt presidentboligen vil bidra til å styrke funksjonen til dette området. Samtidig vil dette bety en utvidelse av et fredet område.

En tidligere hektisk hekkeplass for arktisk terne, strandsnipe og tjeld var dekket med høyt gress og lupin. Den store kolonien av hekkende fugler forsvant til tross for at kysten utenfor er rik på småfisk. Området er nå restaurert og flere arter og flere fugler bruker området nå. Våren 2009 ble det igjen observert hekkeaktivitet ved bvottatjörn.

Borgå

Kommunen har opprettet en nasjonalbypark i 2010. Nasjonalbyparken ivaretar de særtrekk som bidrar til å fortelle byens historie. En nasjonalbyparkstatus vil også sikre områdene når byen vokser og presset blir større. 
Marens Eng er et av de viktigste områdene innenfor Borgås nyetablerte nasjonalbypark. Denne gamle hagemarken har høy landskapsverdi og biotopverdi og det er satt i gang tiltak for å holde denne i hevd. Området blir ofte besøkt av skoleklasser og fungerer utmerket som lærested om biologisk mangfold. Stedet blir oftere oppsøkt nå enn før fordi folk er mer bevisste på dets betydning for artene og bynaturen.

\section{Hammerfest}

Kommunen setter ut kunstige fiskerev. Dette er et system bestående av plasrør. Så langt viser tiltaket et markant oppsving i biologisk mangfold på stedet. Revene fungerer blant annet som gjemmested for fiskeyngel. Hensikten er å erstatte tareskogen som er blitt nedbeitet av kråkeboller. Denne utsettingen er en unik mulighet til å studere mulige tiltak for å restaurere ødelagte marine habitater.

\section{Hedensted}

Øvre del av Skjold $\AA$ har fått mer varierte fysiske forhold i elveløpet. Gytebanker har blitt laget for å skape bedre ynglebetingelser for sjøørret (Salmon trutta trutta). For å sikre tilbakeholdelse av nitrogen (N) og fosfor (P) i elveløpet ble det etablert et nytt våtområde. Dette har forbedret leveområdene for andefugler og vadefugler. Disse tiltakene, samt konstruksjon av et fugletårn, høyner områdets rekreative verdi og formidler i seg selv verdien av biologisk mangfold.

I Hedensted er det minst 30 botanisk verdifulle små naturområder som inneholder truede, sårbare, sjeldne, fredede eller karakteristiske arter i lysåpne naturtyper. For at det biologiske mangfoldet i denne naturtypen skal vedlikeholdes er det satt i gang skjøtselstiltak med beiting.

I sammarbeid med grunneiere er kommunen i gang med miljøsertifisering av skoger ved Vejle Fjord.

Det utarbeides en klimaplan for kommunen for å få en oversikt over områder som blir mest berørt av klimaendringer.

\section{Herning}

Hernings naturpolitikk ble ferdig utformet i 2008 og året etter ble det igangsatt ulike prosjekt fordelt på 10 innsatsområder. Visjonen er å stoppe tap av biologisk mangfold og å sikre fremtidige generasjoner en variert natur. Dette konkretiseres gjennom å sikre eksisterende naturverdier, skape større sammenhengende naturområder, gjenskape våtområder, sikre leveområdene for kommunens planter og dyr og formidling av naturverdier.

Ved å gjenopprette naturen i nedre del av Skjern Å-systemet har laksen fătt bedre levevilkår. Laks stiller store krav til levesteder og er derfor en god indikatorart. Flere fisk i elveløpet vil trekke til seg både fugler og oter. Så langt er det registrert merkbar framgang for laks og den sjeldne elveøyenstikkeren «grønn køllegullsmed» (Gomphus vulgatissimus). 
Klimaendringene er en stor trussel for biologisk mangfold. Mange arter rekker ikke å tilpasse seg endringene og har ikke mulighet til å forflytte seg raskt nok. Med bakgrunn i dette utarbeides det en klimahandlingsplan med konkrete mål. Tiltakenes konkrete effekt på biologisk mangfold lar seg vanskelig vurdere, men reduksjonen i CO2-utslipp fra Herning kommune som geografisk område lar seg måle.

\section{Holstebro}

Som en følge av endringer i landbruket har Holstebros karakteristiske engområder langsomt blitt invadert av piletrær. Foruten en artsrik flora omfatter engene et rikt insekts- og fugleliv. Derfor satte kommunen sammen med grunneiere i gang beiteprosjekter med sau, hest og andre dyr for å bevare disse lokalitetene.

For å forbedre forholdene til stor vannsalamander (Triturus cristatus), spissnutefrosk (Rana arvalis), løkfrosk (Pelobates fuscus) og strandpadde (Bufo calamita) har Holstebro renset opp en rekke dammer og tjern og nå finnes det 88 tjern og dammer amfibiene kan leve og formere seg i.

Tidligere var dambruk for fiskeproduksjon svært vanlig i Danmark. Fire demninger har nå blitt avviklet og $2.5 \mathrm{~km}$ av det opprinnelige elveløpet har blitt gjenskapt. Dette har bidratt til å forbedre passasjeforholdene for laks, ørret og niøyer (lampretter). Til sammen har laksen nå $23 \mathrm{~km}$ med fri adgang i hovedelveløpet og vannlevende organismer som indikerer god økologisk tilstand har vendt tilbake.

\section{Kolding}

I 1988 fikk lobeliesjøen Skærsjø av en uforklarlig grunn svært grumsete vann. Dette var uheldig for bunnplantene «tvepibet lobelie» (Lobelia dortmanna), «sortgrønn brasenføde» (Isoetes lacustris) og «strandbo» (Littorella uniflora) som trives best i klart og næringsfattig vann. I dag er situasjonen bedre, men fremdeles kritisk. Individer av disse artene er ofte overvokst av et tykt lag alger. Kommunen driver også aktiv skjøtsel i tilgrensende våtmarksområder.

Tilførsel av sand i elvas øverste del gjør at arter ikke trives der selv om den er relativt lite forurenset. De fysiske forholdene til elva Åkær er forbedret. Flere slynger på elva og tilførsel av stein og grus på en $17 \mathrm{~km}$ lang strekning skaper flere levesteder for ørret (Salmon trutta), smerling (Noemacheilus barbatulus), bekkeniøye (Lampreta nieri) og oter (Lutra lutra).

\section{Nes og Runavik}

Nes og Runavik er nabokommuner på Færøyene. En undersjøisk tunnel er planlagt fra hovedstadsområdet til Runavik. Tunnelutgangen er planlagt å komme ut rett ved kommunegrensa til Nes og innlandssjøen Toftavatn. Toftavatn er en viktig lokalitet med hensyn til biologisk mangfold. En kartlegging av biologisk mangfold ble for første gang gjennomført i 2009. Det er laget en natursti for å kanalisere fersel og det er også laget informasjonsmateriell. 


\section{Stjørdal}

De rike beitemarkene og slåttemarkene trues av gjengroing og derfor har bygdelaget «Færbøgda i lag» sørget for at den lokale interessen for kulturlandskapet holdes $i$ hevd. Kartlegging av engvegetasjon har gitt et faglig grunnlag for forvaltning av området. Skjøtsels- og restaureringstiltak er nå etablert for 17 områder. I 2008 ble det for første gang arrangert «slåttedag», et vellykket arrangement som skal videreføres. Prosjektet har synliggjort verdien av kulturlandskapet som ressurs for lokalsamfunnet og inspirert til ny aktivitet lokalt.

Vår og høst fungerer strandområdene ved Halsøen-Langøra som rasteplass for vadefugler og andefugler. Arealbruksinteressene for HalsøenLangøra er for øvrig kryssende og det foreligger planer for utbygging for næringsliv, byutvikling, tilretteleggelse for friluftsliv og utbygging av samferdselsanlegg. Gjennom dette prosjektet er konfliktpunktene og utredningsbehovene tydeliggjort.

\section{Trondheim}

I forbindelse med et større veiprosjekt ble Ilabekken åpnet. Tiltak for å redusere forurensningsutslipp fra kommunale avløp har gitt gode resultater for vannmiljøet. Biotoptiltak for å sikre levedyktige sjøørretbestander har også vist seg å være vellykket. Det har blitt observert gyteaktivitet i bekken, hovedsakelig sjøørret, men også laks. Nasjonalfuglen, fossekallen (Cinclus cinclus), og oter (Lutra lutra) ser også ut til å trives i det nye og forbedrede miljøet. Indikatorer for god økologisk tilstand vil kontinuerlig overvåkes av kommunen.

Tiuren (kjäder) (Tetrao urugallus) i Bjørkåsen i Bymarka blir overvåket årlig. Trondheim er en viltrik kommune, men leveområdene for mange arter trues på grunn av fragmentering av leveområder. Tiuren brukes som indikator for ønsket økologisk tilstand i skogen. Tiurbestanden nærmer seg nå en kritisk grense. All hogst har blitt stoppet siden 2007 og det er gjort et politisk vedtak på at ingen nye stier eller skiløyper skal opprettes i dette området.

I et kulturlandskap (Lian-Solem) er det gjennomført systematisk skjøtsel for å sikre området som historisk kulturlandskap. Rydding av gjengrodde arealer og regelmessig slått skal sikre og restaurere biologisk mangfold. Botanisk overvåkning blir årlig fulgt opp for å sikre at skjøtselen er i tråd med intensjonene. Ved å sammenligne data fra 2001 ser man at det nå finnes flere arter her.

\section{Vanda}

Petikko-området (1700 hektar) inneholder over halvparten av Vandas naturvernområder og områder med biologisk mangfold av stor lokal betydning. Petikko er også et populært friluftsområde både på sommer- og vinterstid. Fra 2006 har en arbeidsgruppe jobbet med å utvikle området på en måte som forener hensynet mellom friluftsliv og biologisk mangfold. I 2009 har gruppen kommet fram til en rekke tiltak som skal bidra til at kommunens innbyggere 
får et godt bilde av naturen og rekreasjonsmuligheter. Tiltakene skal iverksettes i tiden som kommer.

I desember 2007 ble det vedtatt ny kommuneplan i Vanda som tar hensyn til biologisk mangfold. Naturvernområdene økte fra $2 \%$ til $6 \%$ av det totale kommunearealet. Regionale utredninger og systematisk kartlegging av planter, fugler, flaggermus, flygeekorn, tresopp, sommerfugler og andre insekter utgjør et viktig grunnlag for denne planen. Naturvernområdene utgjør kjernen på 1450 ha. I tillegg kommer «Luo-områdene» på 800 hektar som er spesielt viktige for naturens mangfold på lokalt nivå. Dette er små områder som ligger utenfor naturvernområdene og der spesielle skjøtselstiltak må til for å bevare naturens mangfold. Øvrige grøntområder på 5700 hektar inneholder små parker, elvebakker og friluftsområder. Vandas kartlegging av biologisk mangfold har også bidratt til å utvide planene om å opprette nasjonalparken «Sibbo storskog». Til sammen spenner det foreslåtte området seg over tre kommuner hvorav 300 hektar skog ligger i Vanda.

Målet med all skogsvern er å ivareta skogenes mangfold og livskraft. Kartlegging av biologisk mangfold er gjennomført og utgjør et godt utgangspunkt for videre overvåkning og oppfølging av biologisk mangfold i Vanda. I LUO-områdene er det åpnet for skogsvernarbeid som styrker områdenes naturverdi og rekreasjonsverdi.

\section{Ørebro}

Ved å rydde opp en gammel søppelfylling og omgjøre en tidligere oljehavn til dampark har Ørebro kommune fått et våtmarksområde med et rikt fugleliv som nå har status som naturreservat. Her her et område som var nesten helt ødelagt blitt fullstendig renovert og dette er nå et populært utfarsområde. 



\section{Bakgrunn for prosjektet}

Under partsmøtet for konvensjonen for Biodiversitet i Haag i 2002, og på verdenstoppmøtet $\mathrm{i}$ Johannesburg samme år ble det vedtatt et mål om å redusere tapet av biologisk mangfold innen år 2010. Dette ble forsterket på ministerkonferansen i Kiev i 2003, til at målet er å stanse tapet av biologisk mangfold i Europa innen 2010. De nordiske regjeringene har sluttet seg til dette målet.

Alle de nordiske landene har forpliktelser mot 2010 målet, men uten lokalsamfunnenes medvirkning vil det være svært vanskelig å nå dette målet.

Prosjektet passer godt inn i den nordiske bærekraftstrategien. Strategiens punkt 5.2 understreker at de nordiske landene skal være i front når det gjelder å ta vare på biodiversiteten: «.. de nordiske länderna skall vara föregångare när det gäller att bevare den biologiska mångfalden.» 2010 målet er sentralt i den nordiske miljøhandlingsplanen 2005-2008. Prosjektet er en direkte oppfølging av strategien for et «Bæredyktig Norden».

Med denne bakgrunn ble det i 2006 etablert et nordisk prosjekt i regi av Nordisk Ministerråd der 14 nordiske kommuner deltar.

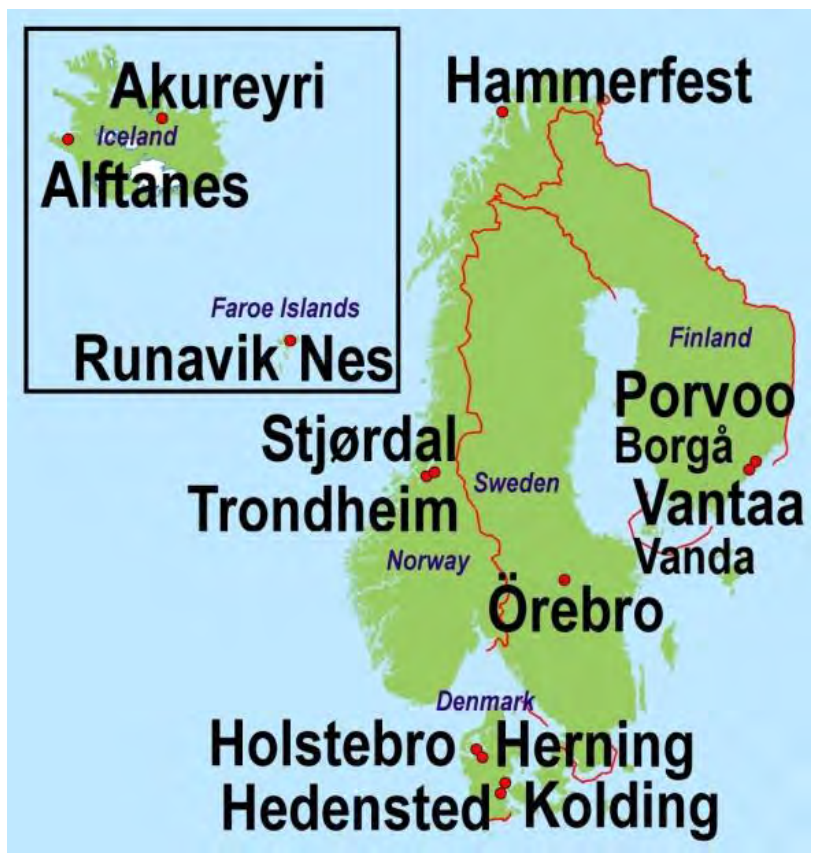

Fig. 1 Kommunene som deltar i prosjektet. 
Nedenfor følger webadresser til alle de deltagende kommunene:

- www.akureyri.is

- www.alftanes.is

- www.porvoo.fi

- www.hammerfest.kommune.no - annen nettportal: www.hammerfest.no

- www.hedensted.dk

- www.herning.dk

- www.holstebro.dk

- www.kolding.dk

- www.nes.fo

- www.runavik.fo

- www.stjordal.kommune.no

- www.trondheim.kommune.no - annen nettportal: www.trondheim.no

- www.vantaa.fi

- www.orebro.se 


\section{Prosjektbeskrivelse}

Kommunene som ble forespurt om å delta var kommuner som hadde satt biodiversitet på agendaen. De ble bedt om å melde inn konkrete prosjekter som de senere skulle rapportere resultater fra. Eneste føringen på prosjektene skulle være at de var i regi av kommunen selv og at de skulle være relevant for det internasjonale 2010 målet om å stanse tap av biologisk mangfold.

Kommunene som ble med i prosjektet forpliktet seg til følgende:

- Melde inn inntil tre prosjekter som var relevante for 2010 målet som de skulle gjennomføres innenfor denne tidsrammen. Dette trengte ikke være kun nye prosjekter, men også prosjekter som var godt i gang. Det måtte rapporteres status på prosjektene og det måtte gjøres en sluttrapportering i slutten av 2009.

- Kommunene skulle sørge for at det ble lagt ut informasjon om prosjektene på sine nettsider, helst også med en kort presentasjon på engelsk.

- Det var sterkt ønskelig at kommunene som ble med signerte Countdown 2010 deklarasjonen, men det var ikke en betingelse for å bli med i nettverket

- Kommunen som ble med måtte påregne og kunne bli forespurt om å delta på arrangementer og å gi presentasjoner om sitt arbeid på ulike konferanser omkring 2010 målet.

Gjennom arealforvaltingen i kommunene møtes flere sektorer som landbruk, skogbruk, fiskeri, miljøforvaltning og arealforvaltning. Ivaretakelse av biodiversitet blir på det kommunale nivået satt $\mathrm{i}$ en helhetlig kontekst.

Prosjektet så tidlig nytten av det nordiske samarbeidet ved erfaringsutveksling og idedugnad på tvers av landegrensene. Dette gav muligheten til å lære av andres erfaringer og samarbeide om løsninger på felles problemer.

I prosjektperioden har det vært arrangert årlige samlinger. Hensikten med samlingenen har først og fremst vært erfaringsutveksling, men også å stimulere og motiverer til videre innsats. Gjennom deltagelse i prosjektet ville de også bidra tilå sette et sterkere fokus på lokalsamfunnenes og da spesielt kommunenes viktige rolle i miljøarbeidet. Dette kan også være med på å gi en positiv identitetsskapning knyttet til kommunen og miljøkvaliteter i kommunen. Følgende samlinger for kommunene har vært avholdt: 
- Oslo, 2006

- Kolding, 2007

- Vanda og Borgå, 2008

- Akureyri og Alftanes, 2009

Bortsett fra den første samlingen i Oslo i 2006 er det kommuner i prosjektet som har vært vertskap for samlingene. Prosjektet har vært presentert på flere internasjonale og nasjonale konferanser der også kommunene har deltatt. 


\section{Succéfaktorer}

- noen erfaringer og rekommandasjoner fra kommunene i prosjektet

Kommunene i prosjektet har sittet sammen og diskutert felles erfaringer og kommet fram til noen felles anbefalinger for hva som er viktig om en skal lykkes med miljøprosjekter på det kommunale nivået. Nedenfor listes opp det kommunene med bakgrunn i sin erfaring mener er de viktigste faktorene for å kunne lykkes.

\section{Lokal forankring}

$\AA$ ha lokale verdifulle biologiske forekomster eller verdifulle kulturmiljø er noe som gir tilhørighet og som både innbyggere, jordeiere, politikere og bedrifter kan være stolte av. Med økt kunnskap følger ønsket om å ta godt vare på disse. I det hele tatt bør man vite hva naturen gir deg og gjør for deg for at du kan forstå hvorfor den skal beskyttes. Derfor er det viktig at forskere har god kontakt med lokalbefolking og politikere. Det er spesielt viktig å skape interesse for og eierskap til framtidig skjøtsel.

Lokalt engasjement i den demokratiske prosessen verdsettes høyt av politikerne. Derfor er det viktig å ha kontakt med nettverk som innbyggerforeninger og lokale miljøorganisasjoner.

En god start for arbeidet $\mathrm{i}$ en kommune er å knytte biologisk mangfold til et aktuelt pågående utviklingsprosjekt. Slike prosesser, som allerede er i gang, har fokus i lokalmiljøet og det gir bedre rom for å skape interesse for biologisk mangfold.

\section{Politisk forankring og engasjement}

Nasjonale initiativer fører ikke nødvendigvis til lokale tiltak, spesielt ikke i små kommuner. Derfor er det viktig å engasjere og involvere både politiske organer og enkeltpolitikere. For eksempel kan det holdes offentlige møter når et naturprosjekt settes i gang, eller politikere kan inviteres til befaringer $\mathrm{i}$ viktige områder.

For å få tilslutning hos lokal politikerne trengs et handlingsprogram for naturmiljø og biologisk mangfold. En oversikt over områder med verdifullt biologisk mangfold og på hvilke måter disse kan være truet er også nødvendig. Biologisk mangfold er ofte koblet til kulturmiljø og friluftsområder og disse bør ses i sammenheng. På denne måten kan bevaring av biologisk mangfold ses som en forutsetning for andre verdier. Det er best om ressurskrav også kobles til handlingsplanen.

Det har stor betydning å få informasjon i god tid før avgjørelser skal tas. Det gir en god forankring hos relevante interessenter og det gir tid til å få fram gode ideer som kan bidra til å oppnå gode helhetsløsninger der alle berørte parter er 
representert. Dette er også grunnlaget for en god arealbruksplan for kommunen med lokale, regionale og nasjonale interesser.

Etter hvert som nye politikere kommer til kan det komme nye vurderinger. Derfor bør de langsiktige perspektivene sikres med bred politisk forankring.

\section{Kompetanse}

Kompetanse er viktig og det gjelder å ta vare på de muligheter som finnes. Spesielt tverrfaglig samarbeid og samarbeid med nabokommuner er nødvendig og gir verdifull kompetanseutvikling som er til stor nytte i det daglige arbeidet. Det øker også innsikten i hvilke spørsmål det går an å søke svar på. Ikke alle kommuner har ansatte som jobber direkte med biologisk mangfold. Dette gjelder særlig de små kommunene. Selv større kommuner kan ha mangel på folk med god kunnskap om biologisk mangfold. I disse tilfellene viser de seg at personlig og lokal interesse er avgjørende for å realisere et prosjekt.

\section{Naturformidling og naturen som loerested}

Tilgangen til et godt naturmiljø for skoler og barnehager har ofte bred politisk støtte, men for å få formidlet verdien av biologisk mangfold er gode kontakter med disse svært viktig. Pågå ende prosjekt er en ressurs som kan utnyttes både mot skoler og barnehager og mot resten av befolkningen. Det at noe skjer og er under utvikling skaper i seg selv interesse, og offentlige arrangement knyttet til disse kan øke kunnskapen om naturens betydning. Ved at områdene blir tilgjengelige og tatt $\mathrm{i}$ bruk kan folk se artene og naturtypene i en større sammengheng.

\section{Samarbeid mellom nasjonale og lokale nivåer}

Et godt samarbeid mellom nasjonale og lokale nivåer er nødvendig i spørsmål som berører natur- og kulturmiljø ettersom det handler om et delt ansvar. Det er en felles oppgave å beskytte det biologiske mangfoldet. Det bør være åpne dører mellom partene i samarbeidet. Og det er ønskelig at myndighetene på sentralt nivå har mulighet til å samarbeide om prosjekter, etc. på lokalt nivå.

\section{Finansieringsmuligheter}

Muligheten for at fă naturprosjekter finansiert er avgjørende. Utviklingsprosjekter for boliger, ferdselsårer og industri kan gi gode muligheter. I slike prosjekter er det som regel betydelige økonomiske ressurser, som gjør det lettere å få finansiert et delprosjekt om biologisk mangfold.

En annen mulighet er å hjelpe andre med å skaffe ressurser til prosjektet. Da kreves et bredt samarbeid mellom internasjonale, nasjonale og lokale NGOer; EU og nasjonale og lokale myndigheter; organisasjoner som Nordiske Ministerråd og industrien for å få fram ressurser. 


\section{Internasjonalt samarbeid}

Dette Nordiske samarbeidet har gitt deltagerne mulighet til å se samspillet mellom Internasjonale mål og lokale prosjekter og løsninger. Mange av prosjektene i de fjorten kommunene ville ha gått sin gang uten dette samarbeidet, men for en del kommuner har det fungert som en katalysator for framgang i prosjektene. Deltagelse i et nordisk nettverk har også styrket den politiske forankringen. Her er et utvalg typiske kommentarer fra kommunene i prosjektet:

- Prosjektet viser at kommunene har et internasjonalt ansvar, men at de må handle lokalt for å oppnå globale resultater.

- Det er verdifullt å delta i det nordiske nettverket.

- Det har høynet bevisstheten blant deltakerne om viktigheten av gode ferdigheter.

- Det er veldig interessant å se nye prosjekter og løsninger i andre land - en utmerket idébank.

- Prosjektet åpner øynene, slik at vi ser nye perspektiver. Det gir oss mulighet til å fungere bedre hjemme.

Dette prosjektets styrke, sett med internasjonale øyne, er at man har klart å koble lokale prosjekter med et internasjonalt mål, og å spre kunnskap og samarbeidet på tvers av Norden. 



\section{Presentasjon av kommunenes prosjekter}

Internasjonalt er det nå stor fokus på det globale 2010 målet, men det har så langt ikke vært særlig fokus på dette målet på regionalt eller kommunalt nivå. En mobilisering på regionalt og lokalt nivå er helt nødvendig om landene skal kunne nå 2010 målet. Dette nordiske prosjektet vil demonstrere nødvendigheten av og «tenke globalt og handle lokalt». De nordiske landene har sterke og godt organiserte lokalsamfunn og med et klart forvaltningsansvar for biologisk mangfold også på det lokale forvaltningsnivået. Dette gir et godt utgangspunkt for å sette i gang effektive og virkningsfulle prosjekter, og vise at lokalsamfunn har en nødvendig rolle for å nå det ambisiøse 2010 målet om å stanse tap av biodiversitet.

Prosjektene som rapporteres var delvis i gang da det nordiske prosjektet startet og noen av prosjektene var ikke ferdig da de skulle rapporteres i slutten av 2009. Kommunene ble likevel bedt om å rapportere resultatene de hadde oppnådd i prosjektperioden. Prosjektene gir et representativt bilde over arbeidet med å bevare biodiversitet på det lokale nivået.

Prosjektene som inngår i det nordiske samarbeidet spenner fra verneprosjekt, restaurering, biotopforbedrende tiltak, bekjempelse av fremmede arter, skjøtselsprosjekt til bærekraftig skogbruk og klimatiltak. En fellesnevner for alle prosjektene er at de har bidratt til å formidle verdien av biologisk mangfold i sine lokalmiljø. Prosjektene som presenteres her er et uttrykk for hvor forskjellig arbeidet med biologisk mangfold kan og må gripes an.

Her følger en kommunevis presentasjon av alle de lokale prosjektene som var med i det nordiske prosjektet. Kommunene presenteres her i alfabetisk rekkefølge. 



\section{Alftanes kommune}

Álftanes er et lite samfunn, med omkring 2500 innbyggere. Kommunen ligger på en halvøy («nes») med nær tilknytting til Reykjavík og tilsluttende byer, hvor minst halvparten av Islands befolkning er bosatt. Nesets historie er nær tilknyttet strandfiskeri med åpne båter, som ble avsluttet mot slutten av 18. hundretallet. Dermed falt antall innbyggere drastisk og igjen sto noen fåtall gårder som satset på melkeproduksjon og sauedrift. I den følgende tidsperioden ble en del våtmark drenert og stranden sikret mot vest, hvor havets bølger gjennom tiden har vasket bort store landarealer.

Mens Reykjavík og omegn vokset raskt etter siste verdenskrig øket også interessen for bosetning på det fredlige og naturskjønne området i nærheten av hovedstaden. Men samtidig var det også interesse for å bruke området til oppbygging av en internasjonal flyplass og derfor var vedtok regjeringen et forbud mot nybygginger på Álftanes. Dette ble opphevet 1973.

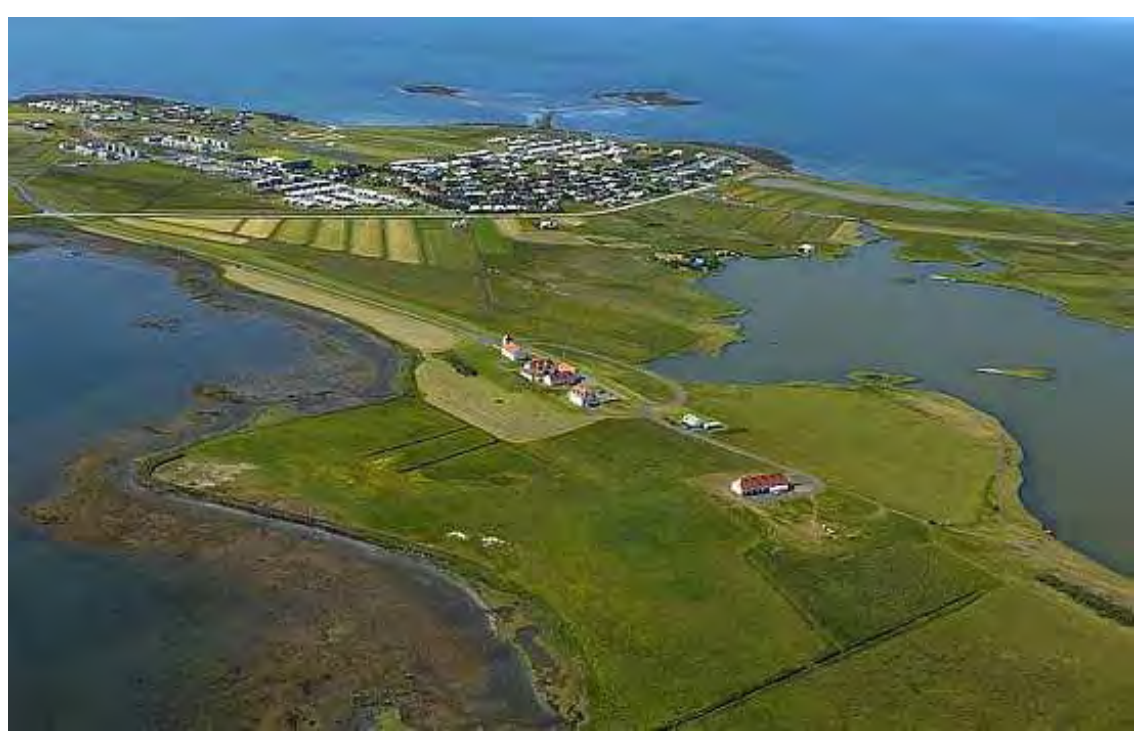

Fig. 2. Flyfoto av Alftanes, viser presidentens resisdens Bessastaðir og byggden vestenfor. Foto: Alftanes kommune.

På tross av at antall innbyggere er fordobblet hvert tiår ifra vedtaket var opphevet er der fremdeles store åpne arealer og et mangfold av fugler som søker føde og hekkeplasser i området. Alpingi, den Islandske nasjonalforsamlingen, vedtok miljøministerens forslag om planer til vern av boplasser for fugler langs strandområder sør for Reykjavík, og dermed imøtekom internasjonale avtaler om vern for trekkfugler. Verneområdet innbefatter Skerjafjörður, en skjermet og grunn fjord der ligger mellom Álftanes og Reykjavík. I april 2008 undertegnet både miljø- og undervisningsministere, samt 
bystyreren på Álftanes, erklæring om å satse på den nevnte verneplan på lokalt hold og oppbygging av informasjonssenter for verneområdet og på Álftanes, samt tilretteleggelse av miljøopplæring og kurstilbud.

Tilbudet om å delta i et nordisk nettverk som tok sikte på lokale tiltak for å bevare biologisk mangfold, i tråd med 2010-målet, passet godt til kommunens målsetninger og befolkningens ønske om vern av gjenstående natur. Ideer om vern av store åpne arealer for fugleliv og våtlandsvekster, samt langstrakt uberørt strand, tilknyttet etablering av bæredyktig drift med miljøopplæring og tjeneste for turister.

To prosjekter ble definert for Álftanes i tråd med 2010-målet og det Nordiske nettverk.

\subsection{Prosjekt 1. Restaurering av strandområde ved pvottatjörn på Hliðstanga}

For omtrent 20 år siden ble utkanten av et fredet område forhøyet og planert for noen eneboliger. Nå er plassen dekt med høyt gress og alpine lupine. Før var der en populær hekkeplass for bl.a. arktisk terne og sandsnipe som begge foretrekker sandholdig jord og glissen strandvegetasjon. Nå er det kun et fătall fugler som hekker i området, til tross for at kysten utenfor er rik på småfisk og er munningen til en poll (grunn fjord). Hensikten er å gjenskape landskapet, dekke overflaten med sand fra havbunn i et forsøk på at terne etablerer seg på nye kolonier i det området.

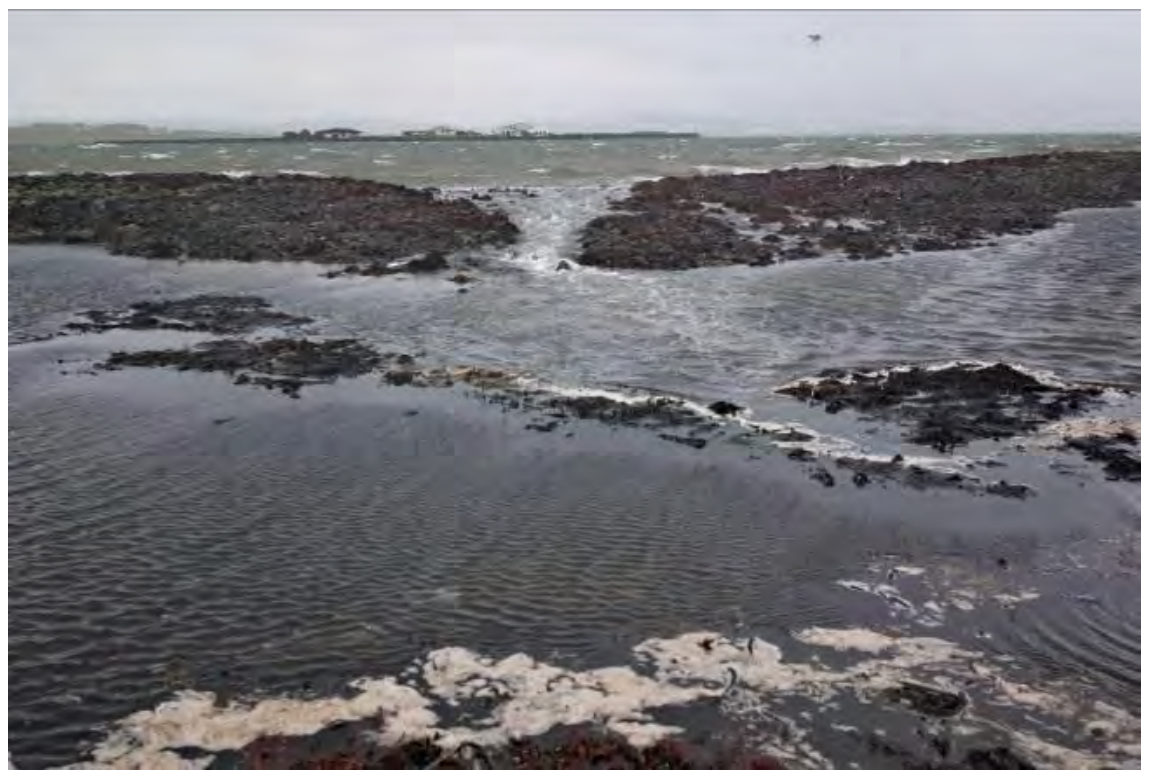

Fig. 3. Havvand strömmer hver vår og høst over i tjernet i friluftsparken, naar det er høyvand.

Foto: Alftanes kommune. 


\section{Tiltak og resultater}

Det planlagte arbeidet med landforming før hekketidens start våren 2008 ble forsinket og man fikk nøye seg med nedbeiting av marken, der skyldes vinterbeite av hester tidligere i året. Det førte til at noen fugl forsøkte hekking.

Høsten 2008 gikk man derimot løs på landforming ved bvottatjörn. Bulldoser ble anvendt til å flytte oppfyllingsmaterialet opp i hellingen mot nord, ovenfor tjernen og jevne det ut for senere oppdyrking av grasmark. Den gjenskapte fordypning østover og i plan med tjernet, ble dekket med havsand og grus. Såing i hellingen op mot veien ovenfor fik vente til begynnelsen av mai 2009. Frø av Islandsk gress Festuca rubra (túnvingull) ble brukt. Allerede i den tiden kunne man merke stor interesse fra fugler i området og arbeid med maskiner ble dermed avsluttet.

I løpet av våren hekket det både en handfull sandlo og en flokk på omkring 50 arktiske terner, i tillegg til en del, men mer spredte hekkende tjeld, rødstilk og enkelbekkasin. Generelt kan man fremheve at det var både flere arter og flere fugler som har benyttet området enn tidligere. Gressfrøene vokste derimot ikke så godt som man hadde forventet, antageligvis på grunn av usedvanlig varig tørketid. Skrenten er derfor fremdeles noe bar. Både hellingen og sandflaten øst for tjernet blir nok sakte men sikkert tildekket med vekster.

\subsection{Prosjekt 2. Restaurering av drenert våtmark ved Kasthúsatjörn, utvidelse av vernområdet og forbedring av hekkeplasser.}

Omkring midten av siste århundre var store arealer med våtmark og strand forandret til dyrka mark. Prosjektet ved Kasthúsatjörn er et langsiktig arbeid for å gjenskape våtmark $\mathrm{i}$ et område der tidligere landeiere har drenert og brukt hovedsaklig til beiting.

Ved å fylle igjen grøfter og delvis heve vannnivået skal omgivelsene tilrettelegges for naturlig spredning av de våtmarksvekster man kan fremdeles finne langs kanaler og tjern. Landforming skal ta sikte på best mulig og tilrettelegge hekkeplasser for stedets fugler. Det dreier seg om regulering av trafikk i området på markerte stier, samt formidling av opplysninger om hvor viktig det er å ikke forstyrre fugl på hekkeplasser. Opplæring og overvåkning er en viktig del av planen. 


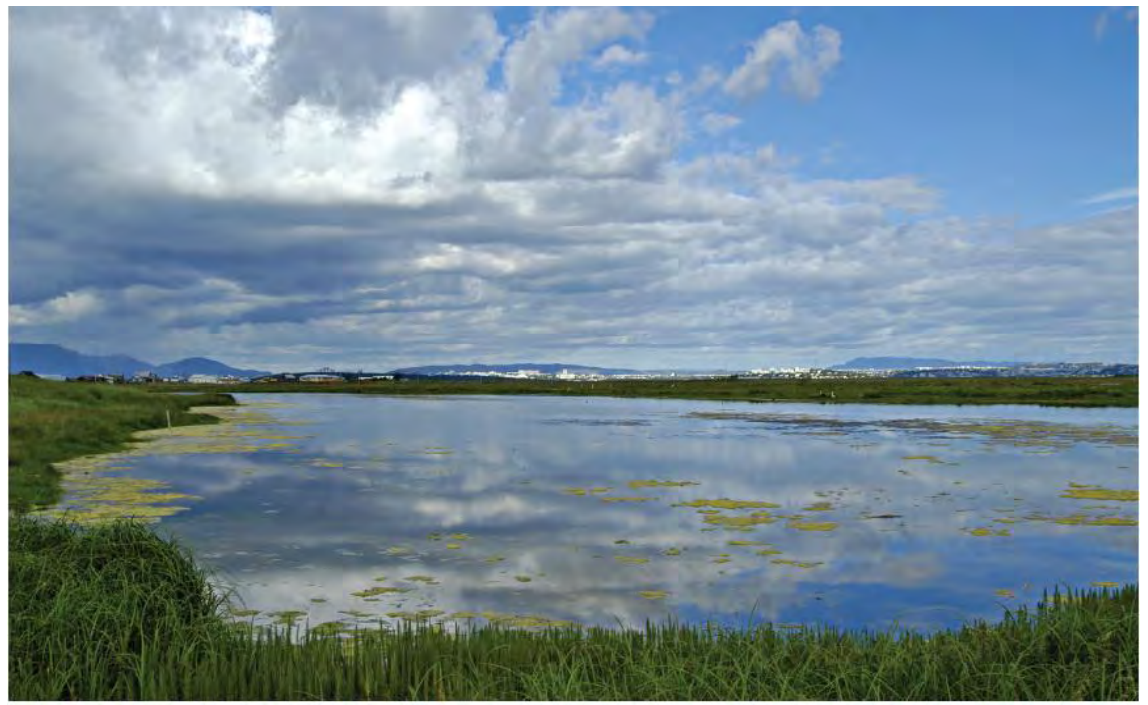

Fig. 4. Kasthúsatjörn er den centrale del av det område der skal igenskapes til våtmark.

Foto: Alftanes kommune.

I en foreliggende rapport er forekomsten av både vekster og fugler i området beskrevet. I anledning av denne plan har en ornitolog laget en redegjørelse for forholdene, slik de er nå, og uttalt seg om hva vi kan oppnå og foreslått hvordan vi kan gå frem for å nå de ovenfor nevnte mål. Forholdene skal registreres før utførelsen av planlagt restaurering av våtmark starter og deretter skal utviklingen overvåkes i samarbeid med naturforskere og kommunens skole.

Prosjektet pågår fortsatt og resultaten som presenteres nå vil derfor bli subjektive, med henblikk på oppstart av restaureringsarbeidet og eventuell landforming og heving av nåværende vannstand.

\section{Resultater så langt}

Restaurering av våtmark er et tidkrevende prosjekt. Bystyret har samtykket $\mathrm{i}$ denne plan for bruk av området, omkring 20 ha. Islands spesialist på våtmarksøkosystemer, Dr. Hlynur Óskarsson, er blitt engasjert som rådgiver og har påtatt seg at formidle oppgaver til studenter i forbindelse med restaureringen. En B.Sc. oppgave for studie av miljø og planlegging ved Landbruksakademiet er påbegynt. En landskapsarkitekt arbeider med foreslag til landforming, stier osv., med sikte på fremtidens utnyttelse av våtmarksarealet og omegn.

Prosjektet kan visstnok ta fat på en del av det tilsiktede areal, men uforutsette nedgangstider i landets og kommunens økonomi har redusert slagkraften for bl.a. denne virksomhet. Forhandlinger med privateiere pågår og målet er fremdeles klart, men det praktiske arbeidet vil bli noe forsinket. De tidligere nevnte erklæringer om større vernområde sør for Reykjavík, undertegnet i april 2008, kan forandre prosjektets status hvis blikket blir fokusert til Álftanes i forbindelse med vern av boplasser for trekkfugler. 


\section{Akureyri kommune}

Akureyri ligger i Eyjafjördur på Nord-Island. Byen er kjent for sitt miljøengasjement og blir derfor kalt «den grønne by». Her bor det 17000 mennesker. Hrísey, en øy lenger nord i Eyjafjördur, er også en del av kommunen.

\subsection{Prosjekt 1. Hrísey - gjenskape vegetasjon}

Utbredelsen av fremmede arter gir negative konsekvenser for fuglelivet. Artene hundekjeks (Anthriscus sylvestris) og sandlupin (Lupinus noatakensis) tar overhånd og dekker i dag 11-13 prosent av øya. Området med fremmede arter skal slås med jevne mellomrom og planen er å så frø fra islandsk flora for å gjenskape det biologiske mangfoldet. Sammenligning av flyfoto og vegetasjonsanalyser før og etter tiltak vil vise framgangen $i$ prosjektet.

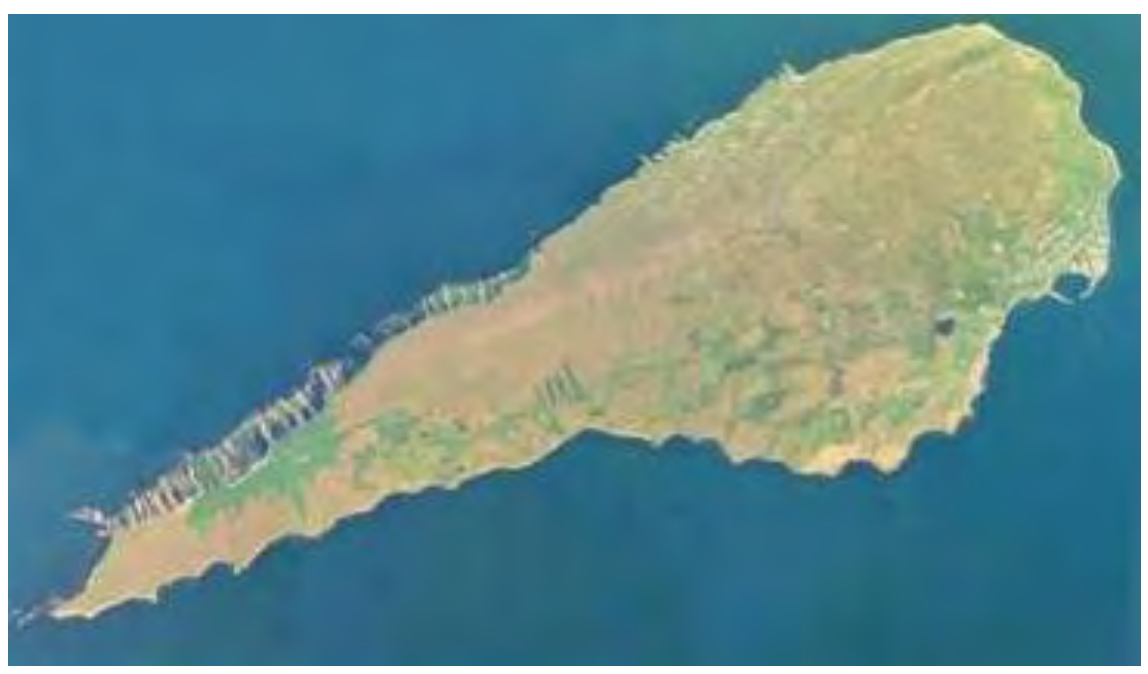

Fig. 5. Invasjon av to fremmede arter (invasive species) Lupin sp. og hundekjeks (Anthriscus sylvestris) på Hrisey (se de grønne områdene til venstre på bildet).

Foto: Akureyri kommune. 


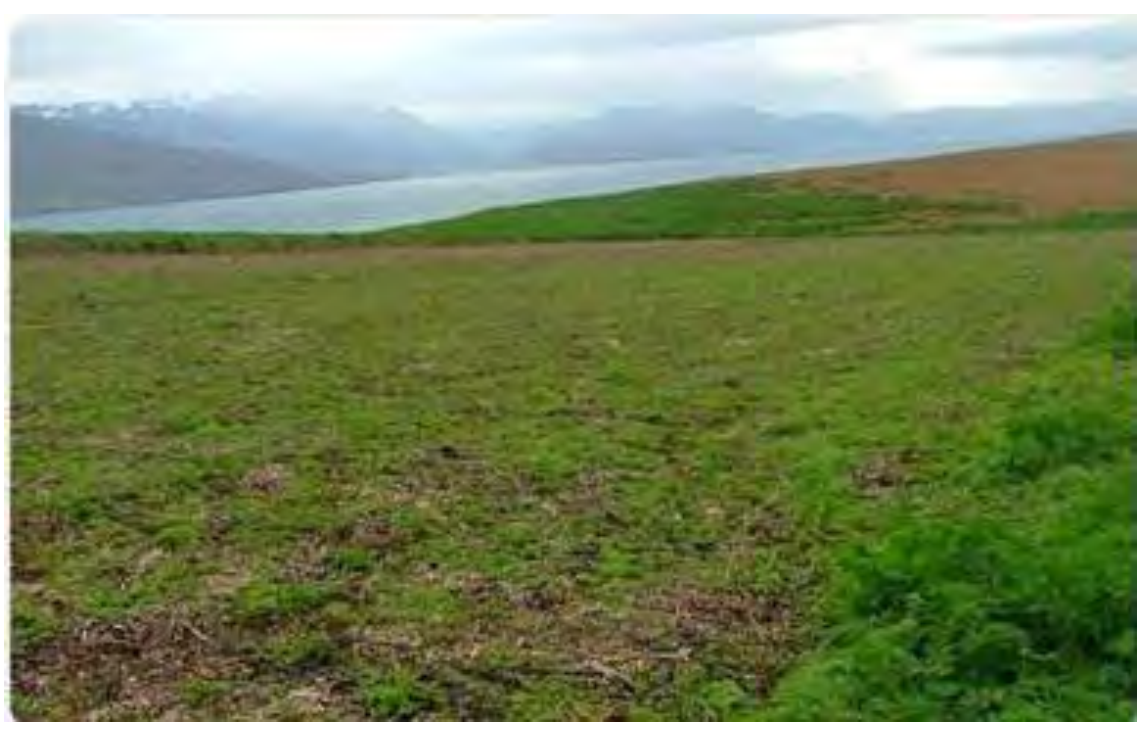

Fig. 6. Bekjempelse av den fremmede arten hundekjeks (Anthriscus sylvestris) ved slått. Foto: Akureyri kommune.

\subsection{Prosjekt 2. Glerárdalur - gjenskape vegetasjon}

En tidligere søppelplass ved inngangen til Glerárdalur friluftslivområde skal restaureres. Åpningen i vegetasjonen utgjør 30 hektar. Nå skal områdets landskapstrekk gjenskapes slik at det faller naturlig inn i resten av området og det skal sås frø fra islandsk flora for å gjenskape vegetasjonsdekket. Resultatet måles ved å sammenligne flyfoto og å gjøre vegetasjonsanalyser før og etter tiltak.

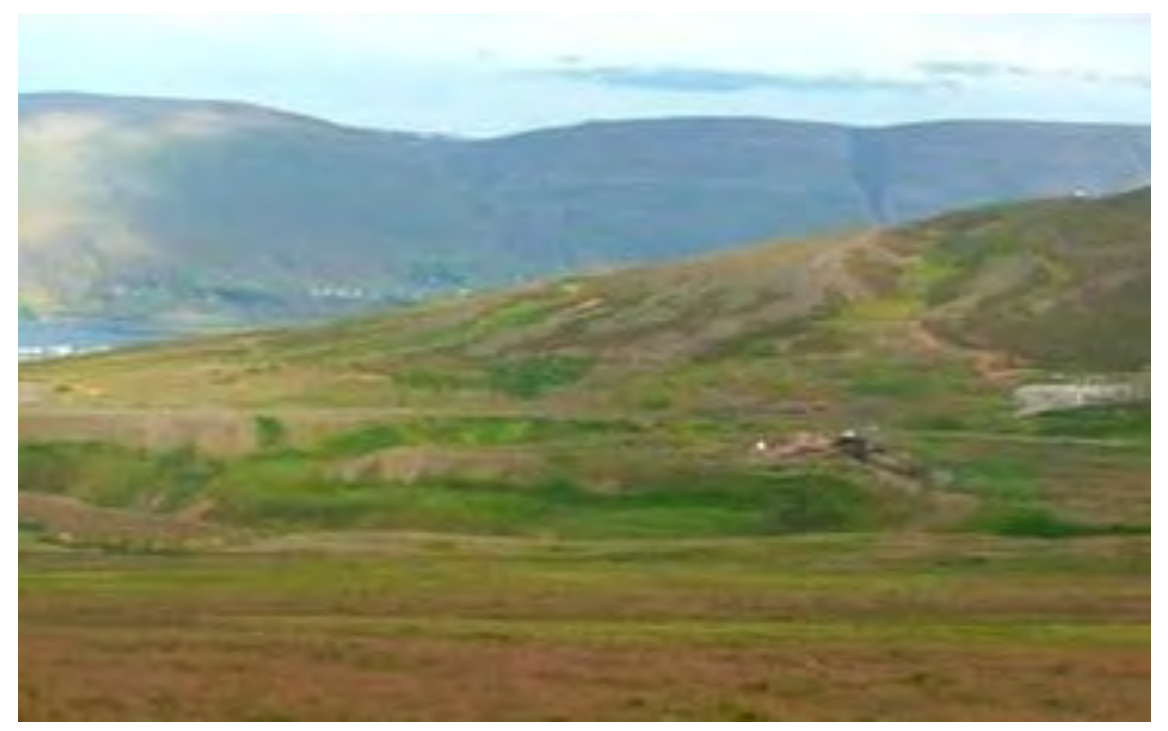

Fig. 7. Reetablering av vegetasjon på tidligere fyllplass.

Foto: Akureyri kommune. 


\subsection{Prosjekt 3. Naustaborgir - restaurering av våtområde for fuglelivet}

Naustaborgir (10 hektar) er en del av friluftsområdet nord for Akureyri. Tidligere var dette et landbruksområde, og det ble derfor ryddet og drenert. Den naturlige floraen endret seg som et resultat av dette. Nå skal det skapes betingelser for naturlig rikt fugleliv og Hundatjörn skal bli større. Grøftene skal lukkes slik at naturlig tilsig av vann samles som før i tiden. Høyspentledninger skal legges i jord og området skal gjøres tilgjengelig for almenheten ved å lage stier og overganger.

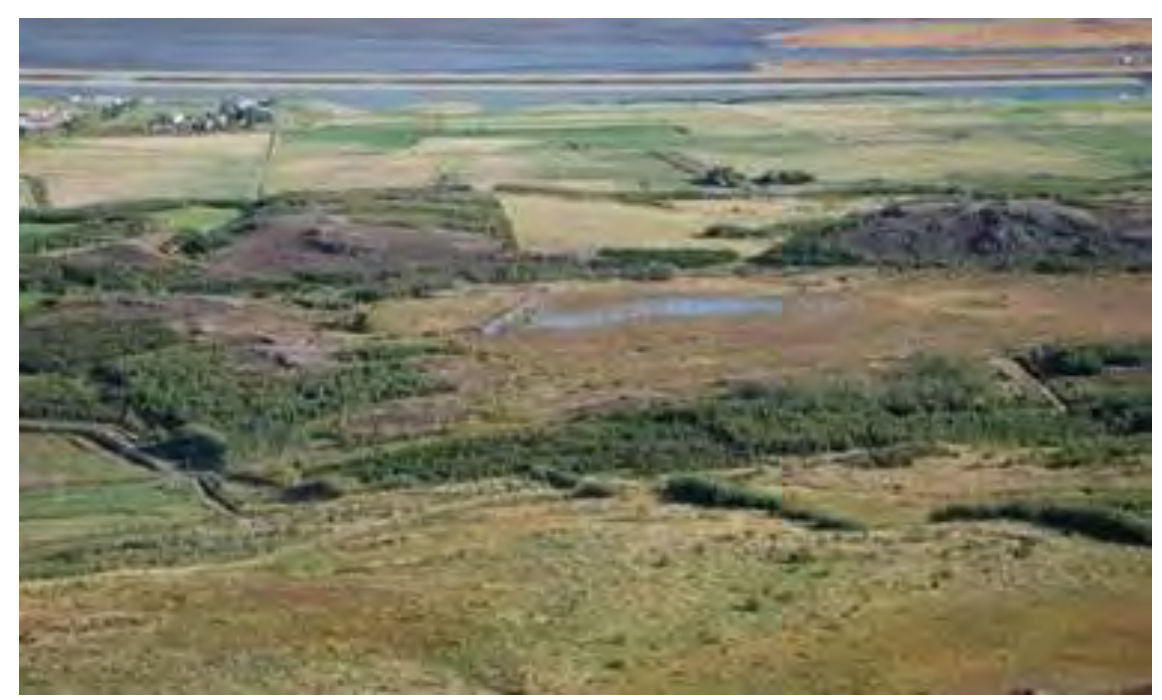

Fig. 8. Restaurering av våtmarksområdet Hundatjörn (midt på bildet).

Foto: Akureyri kommune. 



\section{Borgå kommune}

Borgå stad är belägen i östra Nyland vid Finska vikens kust ca $50 \mathrm{~km}$ öster om Helsingfors. Invånarantalet är ca. 48227 (per 31.12.2008) och staden är 21 i storleksordningen bland landets städer. Borgå stad är centralort för östra Nyland, som har ca 95000 invånare.

Borgå stad grundades ursprungligen år 1346. Stadens område fördelar sig på centrumområdet, de större bostadsområdena i närheten av centrum samt sju bycentra och ett utbrett landsbygds- och skärgårdsområde.

Huvuddragen i landskapsstrukturen är småskaliga. Mellan låga berg- och moränåsar ligger dalar med lerjordar. Typiska element i landskapet i norra delen av Borgå är skogar och öppna odlingsområden i ådalar. Skogar och åar representerar en varierande och rik sydfinländsk kustnära natur. Växtgeografiskt sett ligger Borgå vid den norra gränsen av den hemiborealiska zonen. Södra delen av staden är småskaligt skärgårdslandskap.

\subsection{Projekt 1. Inrättande av nationalstadsparken i Borgå}

Att bereda en nationalstadspark innebär planering av markanvändningen på lång sikt. Området är en $16 \mathrm{~km} 2$ helhet av kulturhistoriskt och biologiskt värdefulla grönområden och naturskyddsområden samt byggd kulturmiljö, som ska bevaras också i den framtida markanvändningsplaneringen.

Markanvändnings- och bygglagen 68 : "För att bevara och vårda kultureller naturlandskapets skönhet, naturens mångfald eller historiska särdrag inom ett område som hör till den urbana miljön eller därtill anslutna värden i stadsbilden, sociala värden, rekreationsvärden eller andra särskilda värden kan en nationalstadspark inrättas. För en nationalstadspark kan avsättas områden som $i$ en plan enligt denna lag har avsatts som park, rekreations- eller skyddsområde, värdefullt landskapsvårdsområde eller för någon annan användning som är lämplig med tanke på syftet med en nationalstadspark. För en park avsätts i första hand områden som ägs av staten, kommunen eller något annat offentligt samfund. Andra områden kan avsättas för parken med ägarens samtycke. Ägarens samtycke behövs dock inte, om det för området inte i beslutet om att inrätta parken eller i skötsel- och nyttjandeplanen utfärdas bestämmelser enligt 70 §."

Den planerade Borgå nationalstadsparken fyller förutsättningarna för inrättandet. De gällande detaljplanerna och delgeneralplanerna är passande till de mål som ställts för en nationalstadspark. Områdets privata markägare har gett sitt medgivande. 


\section{Projektets mål i förhållande till den biologiska mångfalden}

Målet med inrättandet av Borgå nationalstadspark är att trygga bevarandet och saklig vård av naturnära grönområden i stadens centrum och de nationellt värdefulla naturområdena. De allmänna principerna för en nationalstadspark stöder också områdets privata markägares mål i vården av kulturmiljön samt naturvärden, så att kvaliteten på boendemiljön består.

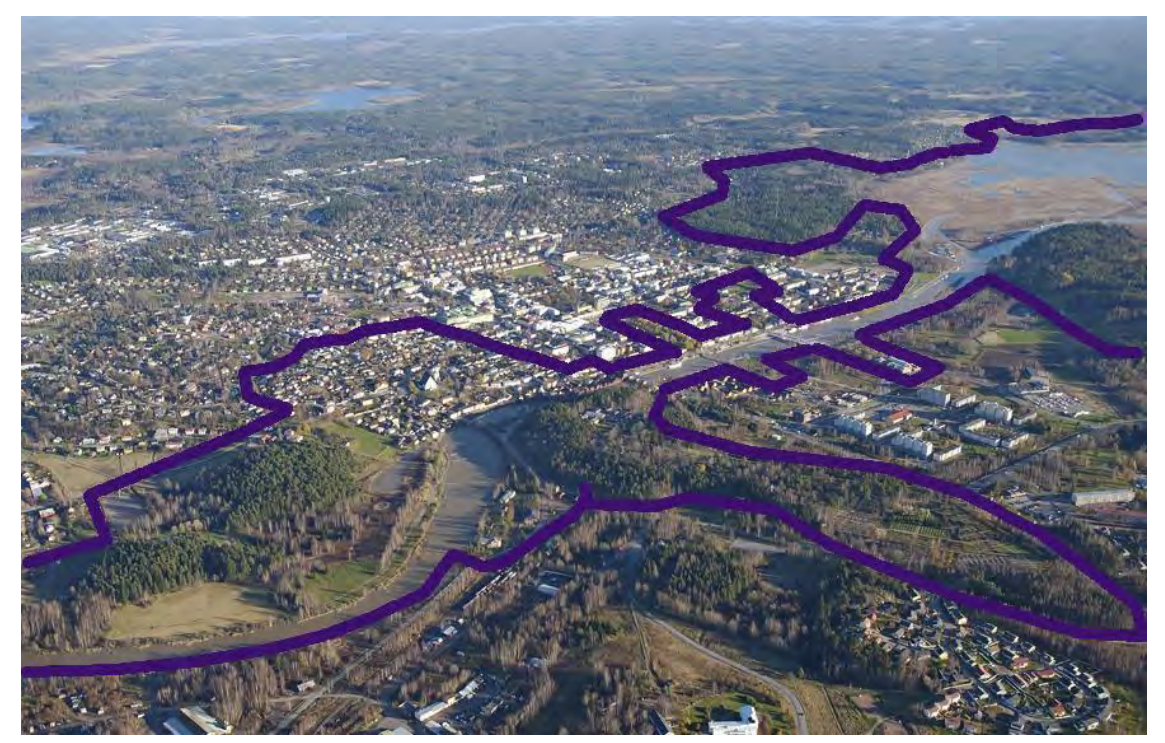

Fig. 9. Avgrensning av Borgå nationalstadspark.

Foto: Borgå kommune.

\section{Genomförda åtgärder}

Beredningen av en nationalstadspark började på basis av ett initiativ. Vid utarbetandet av delgeneralplanen år 2002 fanns tre alternativ till avgränsning och de flesta åsikter var för det största alternativet. I offentlig diskussion behandlades områdenas natur och värden. För beslutsfattare och myndigheter ordnades ett seminarium 26.2.2004 och 17.3.2005. Planläggnings- och byggnadsnämnden behandlade frågan vid sina sammanträden 16.6.2005 och 1.9.2005. Stadsstyrelsen behandlade frågan 10.10 .2005 och gav stadsplaneringsavdelningen i uppdrag att börja bereda ansökan och till den hörande nyttjande- och vårdplan för miljöministeriet. Ärendet är anhängiggjort $i$ kulturprogrammet. För privata markägare har frågan presenterats i brev och i information till boende på området samt i seminarium 10.5.2006. Samtycke har erhållits av 150 privata markägare under 2006-2008.

I juni 2009 har Borgå stads fullmäktige godkänt att staden gör en ansökan till miljöministeriet. Stadsstyrelsen besluter 15.12.2009 om att skicka ansökan till miljöministeriet. Miljöministeriet inrättade Borgå nationalstadsparken 18.5. 2010.

\section{Resultat som har uppnåtts}

Naturens mångfald och kulturarv stöder varandra. Med det här projektet har vi lärt att se olika värden tillsammans i en stor helhet. Av området i Borgå nat- 
ionalstadspark har på olika sätt skyddats ca 812 hektar och vedertagna grönområden finns cirka 360 hektar. Med detaljplaner har skyddats 34 ha av stadens centrumområden, såsom kvarteren i empirestadsdelen, Gamla stan i Borgå och Ågatans strandzon. Haiko gårds område ingår i nationellt värdefulla bebyggda kulturmiljöer liksom också åstranden samt Borgå ådals kulturlandskap. Naturarv och kulturarv har stor betydelse i hållbar stadsplanering.

\section{Uppföljning}

Uppföljningen av nationalstadsparkens förverkligande har inte börjat. Men arbetet med skötsel- och nyttjandeplanen har börjat. Vid skötseln av stora grönområden får speciellt stödandet av naturens mångfald en stor betydelse, vilket tidigare har spelat en mindre roll än estetiska mål och mål som tjänar rekreationen. Nationalstadsparken erbjuder en bra möjlighet att sprida information om biotoper och arter i området och om människans inverkan på dem.

\section{Erfarenheter}

Det systematiska arbetet med privata markägare och lokala naturvårdsföreningar har haft en stor betydelse. Samarbetet mellan stadens kultursektor, naturvård, parkskötsel och stadsplaneringen har varit fruktbart. Lokala medier har varit intresserade och spritt information om naturens mångfald $i$ staden. De politiska beslutsfattarna har till stor del godkänt olika skyddsaspekter och den biologiska mångfalden i den långsiktiga stadsplaneringen.

\subsection{Projekt 2. Vård av ängslandskapet vid Marens äng}

\section{Beskrivning av projektet}

Området är gammal beteshage, där det vuxit upp skog sedan 1970-talet. Ängsbiotoper har ändrats till pionjärskogsbiotoper. Den forna ängen vid Maren ligger mitt i staden mellan fornminnena och den medeltida stadsdelen Gamla stan i Borgå. Den är det viktigaste området för naturens mångfald i stadens centrum inom den föreslagna Borgå nationalstadsparken. Intill den fuktiga ängen finns Marens vattenområde med rik växtlighet och den medeltida borgbackens vallar med artrika torra ängar. 


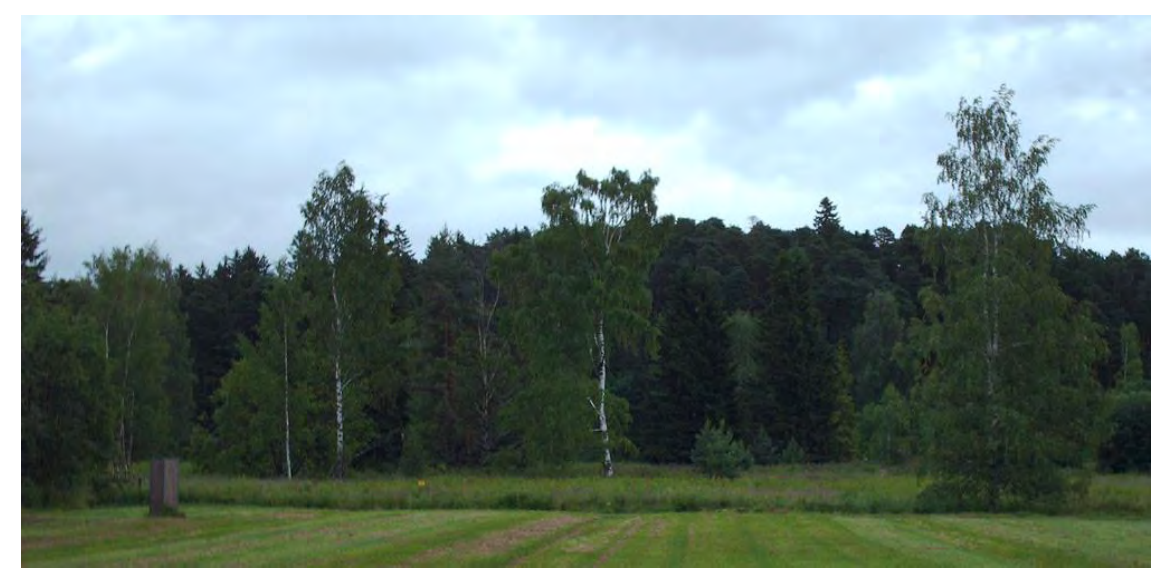

Fig. 10. Englandskap ved Marens Eng.

Foto: Borgå kommune.

\section{Projektets mål i förhållande till den biologiska mångfalden}

Syftet med landskapsvården är att ta bort pionjärskogen och återskapa betesängarna i området. Betande kor är landskapsvårdare som drar med sig en rik fauna. Området ligger mitt i staden och besöks av skolklasser och barnfamiljer och har sålunda ett stort informationsvärde. Till följd av det centrala läget fick den också mycket uppmärksamhet i medierna. Projekten gav goda möjligheter att sprida information av naturens mångfald som beror på kulturverkan.

\section{Genomförda åtgärder}

Den tidigare betesängen öppnades genom avverkning av trädbeståndet $\mathrm{i}$ september 2006 som stadens arbete. En skogsarbetare med häst skötte virkesavverkningen på vintern 2007. Invånarna i närheten avlägsnade hyggesresterna i april 2007. Den lokala $4 \mathrm{H}$-föreningen städade upp området från skräp i maj 2007. En gärdsgård och ett elstängsel runt betesmarken restes i juni 2007. Tre tjurar av höglandsras betade i området tre månader sommaren 2007, 2008 och 2009 utan tilläggsfoder.

\section{Resultat som har uppnåtts}

Landskapsvården har lyckats ytterst bra. Pionjärskogen har tagits bort och området är igen öppen betesmark, där det finns några stora träd som ger skugga åt nötkreaturen. Betesområdet utgör nu en mosaik av fuktiga ängar och högörtsängar. Man har inte inventerat växt- och insektbeståndet efter vården, så man kan inte säga exakt hur arterna har utvecklats. Området besöks ofta av skolklasser och är ett utmärkt objekt för undervisning om naturens mångfald. Området uppskattas mera eftersom man är medveten om dess betydelse för arterna och för stadsnaturen. 


\section{Uppö̈ljning}

I området har gjorts kartläggningar av växtligheten ända sedan slutet av 1800-talet. Sålunda kan man samla in uppgifter om utvecklingen i området under en lång tid. Staden har inte själv möjligheter till uppföljning, utan hoppas att forskare och statens regionala miljöcentral ska visa fortsatt intresse för artutvecklingen.

\section{Erfarenheter}

En skötselplan utarbetades i gott samarbete mellan stadens olika experter och lokala representanter för den lokala naturvårdsföreningen och Borgå museum samt museiverket. Därför var det lätt att få lov att genomföra landskapsvård på ett Natura 2000 -område med olika skyddsaspekter från fornminnesvård till naturskydd och artmångfald. Eftersom området ligger mycket centralt och hör till stadslandskapet har invånarna kunnat följa med hur områdets skötsel skett med gamla, traditionella metoder. Detta har stärkt medvetandet om och förståelsen för växelverkan mellan kultur och natur. Ett besök på Marens äng är en mångsidig natur- och kulturupplevelse. 



\section{Hammerfest kommune}

Hammerfest ligger på 70 grader nord og er verdens nordligste by. Byen fikk bystatus i 1789 , og er sammen med Vardø, Nord-Norges eldste by. Kommunen har 9782 inbyggere og er den nest største kommunen i Finnmark. Hammerfest har lange tradisjoner innen ishavsfangst og fiskeri. Samtidig har kommunen blitt en sentral del av den internasjonale petroleumsindustrien gjennom utbyggingen av landanlegget for Snøhvitfeltet på Melkøya.

\subsection{Prosjekt 1. Utsetting av kunstige rev på havbunnen}

\section{Bakgrunn og mål for prosjektet}

- Sette fokus på problemet med nedbeiting av tareskogen langs kysten av Vest-Finnmark

- Teste ut om et tredimensjonalt substrat (kunstige rev) kan gi/skape økt biologisk mangfold

- Gjenskape/restaurere tareskogen i Sletnesfjorden og i St. Fagervika

- Skape et samarbeid med NGOene og forskningen

- Teste ut om utsetting av kunstige rev kan brukes som et hjelpemiddel/tiltak for å skape økt produksjon av tareskog langs kysten

Utsetting av kunstige rev (Runde Reef) har som mål å tilføre nye og styrke eksisterende undervannshabitater for planter (makroalger) og dyr (virvelløse organismer og fisk), men også å beskytte kystlinjen mot erosjon. Kunstige habitater har vært benyttet for å øke tettheten av skalldyr og fisk, men også for å opprettholde biologisk mangfold og restaurere områder som er blitt forstyrret. Langs norskekysten har det vært omfattende bortfall av tareskog og annen undervannsvegetasjon, noe som har fått konsekvenser for andre organismer som lever eller søker ly i slike områder som danner tredimensjonale habitater. I Nord Norge har kråkebollenes massive nedbeiting renset ca. $2000 \mathrm{~km} 2$ steinbunn for rike tareskoger, og det er blitt stilt spørsmål ved om det finnes metoder for å restaurere disse rike habitatene hvor både tare, virvelløse organismer og fisk har forsvunnet. Hensikten med å sette ut grupper av Runde Reef- enheter var å undersøke om disse kunstige konstruksjonene og habitatene kunne bidra til å gjenopprette undervannsvegetasjon og annet marint liv som har mistet sine habitater på den ørkenlignende bunnen renset av kråkeboller. 


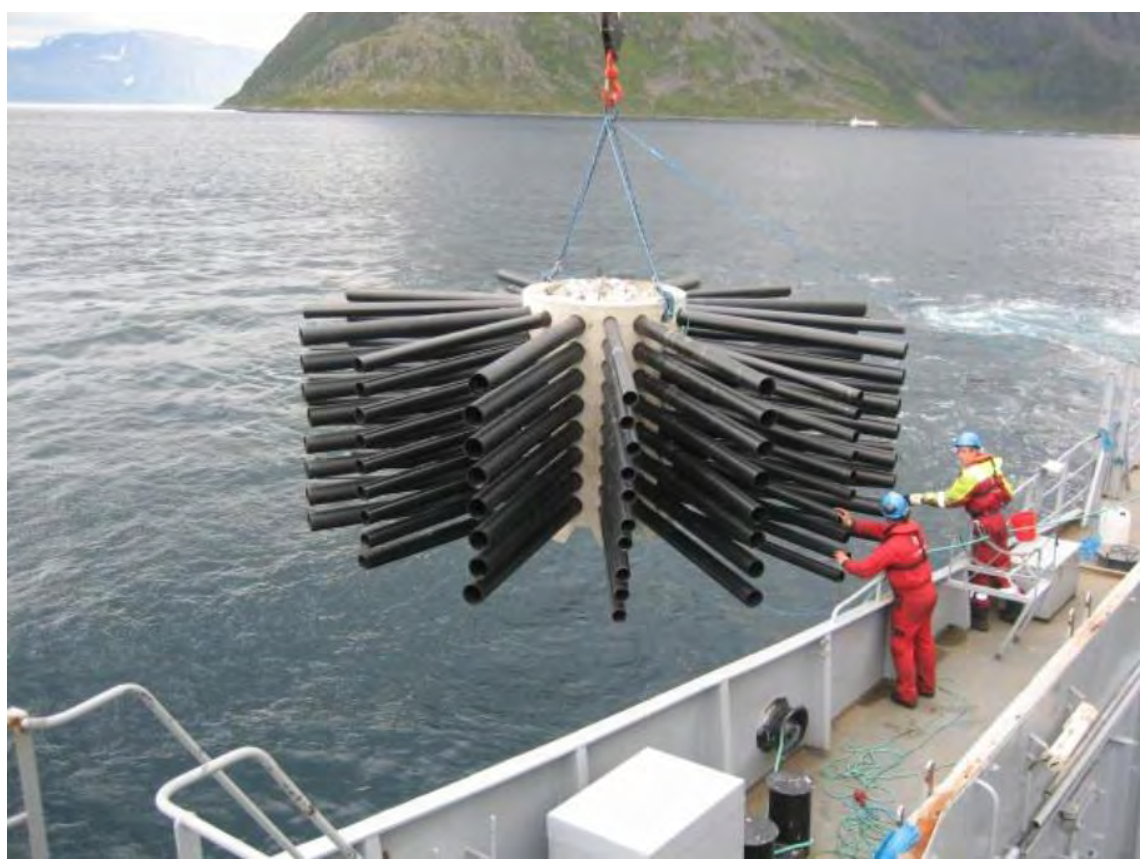

Fig. 11. Utsetting av kunstige rev (Runde Reef) $i$

Sletnesfjorden på Sørøya, juli 2006. Foto: Tom E. Ness.

\section{Tiltak}

Totalt 24 enheter av typen Runde Reef ble plassert på havbunnen på to lokaliteter nært Hammerfest. Begge lokalitetene ligger utenfor Hammerfest by $\mathrm{i}$ delvis skjermede fjorder og bukter som åpner seg mot Sørøysundet med sterke tidevannsstrømmer og moderat bølgeaktivitet. Hensikten var å plassere revene i grupper på 12 enheter i en $3 \times 4$-formasjon med kort avstand mellom enhetene, men utstyret og forholdene rundt utsettingen var ikke egnet til å oppfylle disse intensjonene, og særlig i Fagervika ble enhetene plassert for spredt til og oppnå en «rev-gruppeeffekt». Hver rev- enhet består av en sylindrisk betongkjerne som er 2,35 m høy og 1,6 $\mathrm{m}$ i diameter. Sylinderen er fylt med stein for å øke vekten og stabiliteten, og steinene fungerer og som habitat og skjulested i kjernen av konstruksjonen.

Fra sylinderen stikker 16 vertikale rader av 2,5 m lange plastrør (polyetylen) vannrett ut. Diameteren på rørene varierer mellom $11 \mathrm{og} 18 \mathrm{~cm}$. Til sammen danner sylinderen og plastrørene et utvendig og innvendig overflateareal på $300 \mathrm{~m} 2$. Rørene har en total lengde på $300 \mathrm{~m}$, og den totale vekten er på ca. 8 tonn.

Revene ble satt ut i løpet av de første dagene i juli 2006, og et par enheter ble overvåket av et undervannskamera etter en dag. Revene ble så inspisert av dykkere i september 2006 og to etter tre ganger årlig i 2007, 2008 og 2009.

Registreringen var basert på dykking: video- og fotodokumentasjon, telling av fisk, registrering av planter og dyr som vokser på eller beveget seg rundt revene eller inni gruppen av re-enheter, og likeledes på nærliggende lokaliteter uten rev. 
Statoil ASA, Norsk Hydro har bidratt med finansiering sammen med Hammerfest kommune.

\section{Resultater og diskusjon}

Den grunne bunnen på begge lokalitetene (Sletnesfjorden og St. Fagervika) besto av fjell og stein i de øvre delene og var fullstendig nedbeitet av kråkeboller. Kråkeboller i tettheter på ofte over 20 individer per $\mathrm{m} 2$ har dominert området i flere tiår, og beiter konstant ned alle andre planter og dyr som forsøker å etablere seg i området. Under ca. $5 \mathrm{~m}$ dyp endrer bunnen seg slakt skrånende sand/grus med færre kråkeboller. Ved Sletnes hadde noen makroalger unnsluppet kråkeboller som beitet på sand- og grusbunnen. Allerede en dag etter utsettingen var revene i Fagervika bebodd av et høyt antall (mer en 200 per rev) ungfisk. Disse småfiskene brukte revene som skjulested, sannsynligvis i mangel av andre habitater. Da revene ble inspisert påfølgende oktober, ble det observert spredte fiskestimer (sannsynligvis den samme aldersgruppen av små torskefisk) ved begge revlokalitetene, og revene var begynt å bli begrodd med rørmark, trådformede (Sletnes) og røde (Fagervika) alger. I tillegg til stimene av sei ble det også observert noe torsk, flyndre og mindre dyr som reker, eremittkreps, sjøstjerner, hydroider og snegler på eller langs revene på begge lokaliteter.

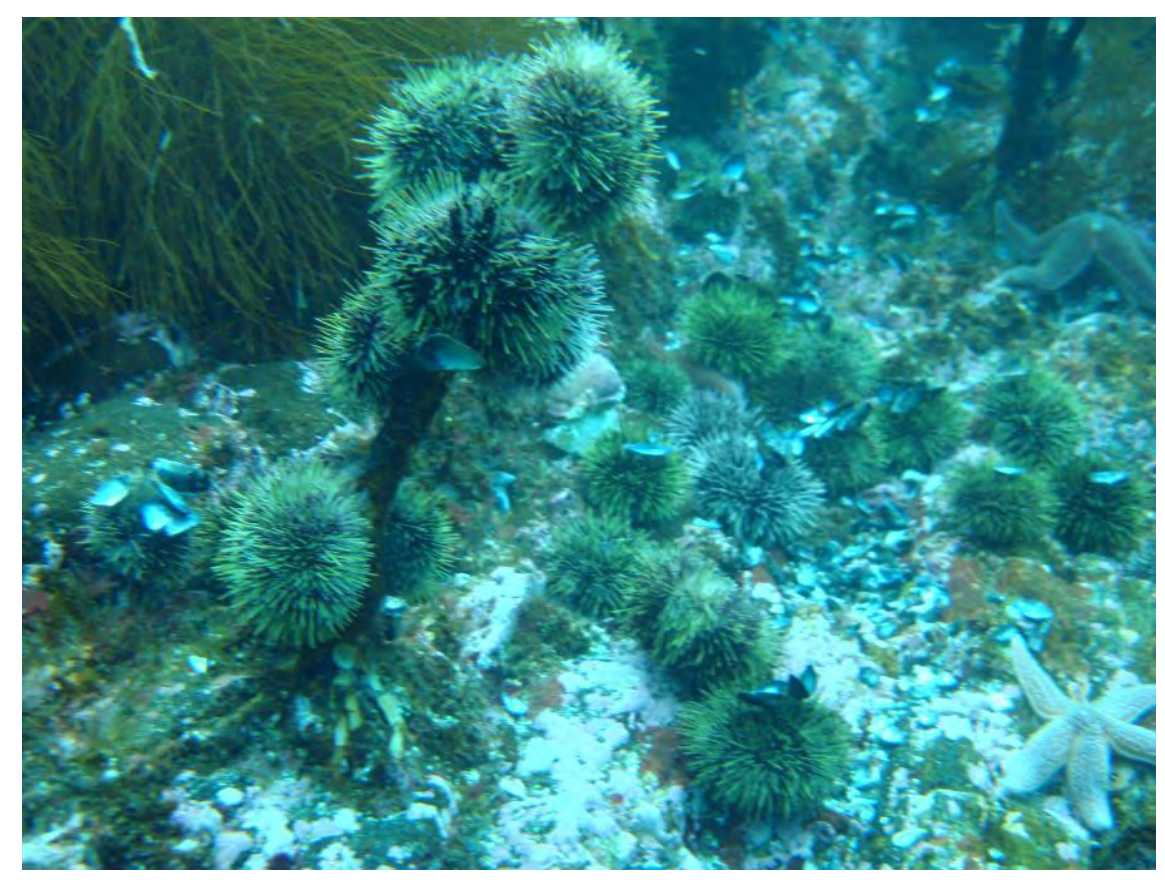

Fig. 12. Grønn kråkebolle har beitet ned om lag $90 \%$ av all tareskog $i$ Vest Finnmark. Foto: Hartvig Christie.

Våren 2007 ble det observert en begynnende vekst av sukkertare, og innen sommeren 2007 hadde sukkertaren etablert seg på og dominerte delvis toppen av revene i Sletnes, sammen med den større trådformede brunalgen Desmarestia. Det ble telt over 30 store sukkertareplanter på hvert av noen av 
de rørene som befant seg på toppen av revet. Revene i Fagervika ble plassert på et dyp som begrenset algevekst, og utviklingen av alger var klart mer moderat enn ved Sletnes, men det fantes likevel en spredt vegetasjon av sukkertare, Desmarestia og rødalge på toppen av rørene. Vegetasjon etablerte seg i løpet av sommeren 2007 og holdt seg gjennom 2008 og 2009. Noen alger etablerte seg også på bunnen rundt rev - enhetene.

Noen kråkeboller fant veien inn i revene og begynte å beite på sukkertaren, men så langt ikke $\mathrm{i}$ et slikt omfang at det er snakk om overbeiting, og revene ved Sletnes er fortsatt helt overgrodd av sukkertare.

I hver sommer- og høstsesong var revene bebodd av ungfisk. Det virket som om ungsei dukker opp omtrent midt på sommeren, og at ungtorsk dukker opp senere. Disse to artene er senere blitt observert i alle sesonger som stimer av sei (liten men ikke ung) som svømmer mer eller mindre tett inntil revene, og et par individer av småtorsk som lever i nærheten av revene. Et antall mindre fisk som uer og tangsprell skjuler seg inni algen eller i kjernen. Også annen fisk som steinbit, rognkjeks/rognkall, breiflabb og flyndre er blitt observert, men i mindre mengder og ikke som permanente beboere. I 2009 ble det observert tre krabbearter på revene og en stadig økende kolonisering av av mindre dyr som reker, trollhummer, andre små krepsdyr, forskjellige sneglearter, sjøstjerner, slangestjerner, sjøpølse, røde og grønne kråkeboller. Disse skjuler seg blant taren/makroalgene, i kjernen eller beveger seg langs revets overflater. Algevegetasjon befinner seg hovedsakelig på toppen og ytterst på rørene, mens den nedre delen av rørene og betongkjernen ikke er begrodd med alger, men snarere rørmark, sjøpunger og hydroider i enkelte sesonger.

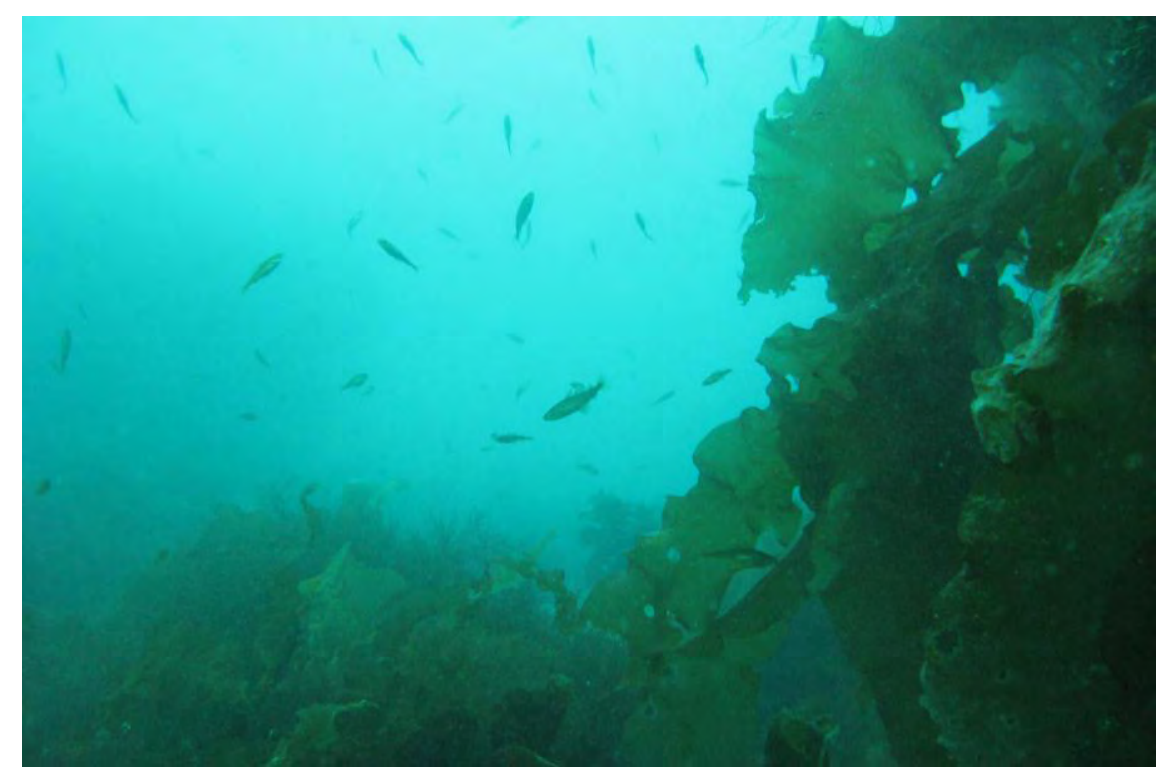

Fig. 13. Sukkertare og yngel av torskefisk på revene i Sletnesfjorden, sommeren 2008. Foto: Hartvig Christie. 
Som konklusjon kan det sies at revene svært raskt ble et skjulested for ungfisk, tare og andre makroalger i et område hvor det er sparsomt med skjulesteder og habitater som følge av at kråkeboller har beitet ned det meste av plante- og dyrelivet. Som følge av dybde og plassering i delvis skjermede fjorder/bukter har utviklingen av tare- og algevegetasjon fulgt et forventet mønster. Det kan imidlertid stilles spørsmål ved om senere etableringer av tare og annen makroalge vil dukke opp på revene ved Sletnes. Enkelte arter sprer seg sent og vil dukke opp senere. Revene har også blitt et skjulested for mange andre mindre dyr og et par fiskearter, og disse forekomstene kan også forventes å øke over tid.

Det mest spesielle ved dette prosjektet er betydningen av revenes utvendige flater som substrat for tare i så langt tre år, og betydningen av de kunstige habitatene med eller uten tarevegetasjon som habitat eller skjulested for ungfisk. Dette og andre observasjoner i området viser at skjulesteder er viktig for ungfisk og rekruttering av fisk, og at revene kan bidra i den sammenheng.

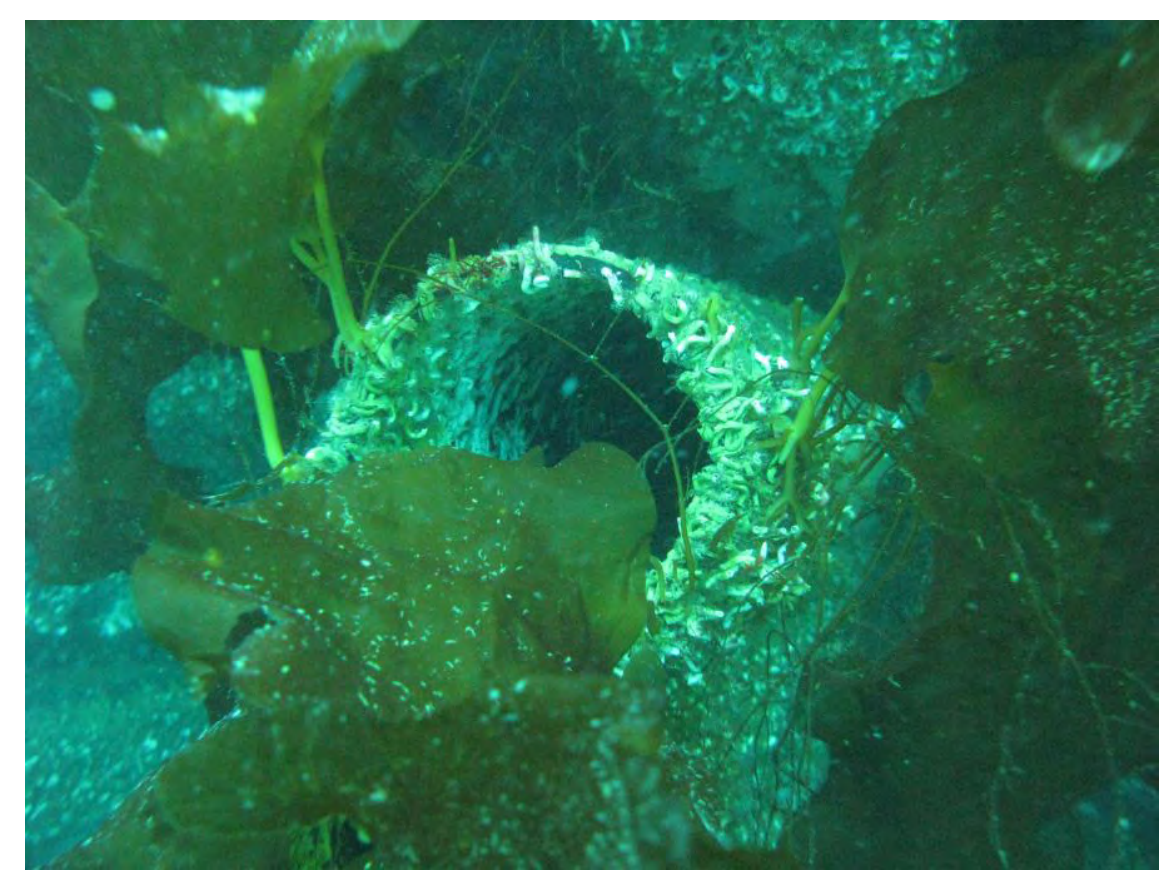

Fig. 14. Sukkertare på revene (PVC rør) i Sletnesfjorden.

Foto: Hartvig Christie.

\section{Laerdom av prosjektet}

Utsetting av kunstige rev i Hammerfest kommune er et høyst uvanlig prosjekt som har vakt stor lokal og nasjonal interesse. Prosjektet har vært lett å markedsføre og å selge inn til mediene. Det er et godt prosjekt $i$ den form at det er nyskapende, og det at det løfter en «glemt problemstilling opp til overflaten». 
Prosjektet utfordrer tradisjonell tenkning innenfor norsk fiskeriforvaltning ved at man «sår i havet», gir noe tilbake, hjelper naturen i gang ved å manipulere den på en «god måte», og ikke bare høster.

Gode samarbeidsprosjekt/partnere, eks. Count Down 2010, er viktig for å få innpulser, tilbakemeldinger, inspirasjon, oppmerksomhet m.m.

Bruk av media, i dette tilfellet lokale, regionale og nasjonale medier, har hatt stor verdi. (Den samfunnsmessige gevinsten må synliggjøres gjennom mediene).

Det er svært viktig og ha en god dialog spesielt med lokale fiskere og fiskarlag, kystbefolkningen og havnemyndigheter.

Lokal politikere må involveres på et tidligst mulig tidspunkt.

Utfordre oljeselskapene til og tenke nytt vedr. avbøtende tiltak, miljøprofilering o.l i de havområdene der de ønsker og utvinne olje og gass.

Den største utfordringen var å skaffe finansiering til produksjon og utsetting av kunstige rev.

\section{Prosjektets videre framdrift}

Med bakgrunn i de gode resultatene fra Sletnes og Fagervika har Hammerfest kommune som mål å videreføre prosjektet. Det jobbes med ulike alternativer løsninger men det er på nåværende tidspunkt ikke tatt stilling til om i hvilken form prosjektet skal videreføres. Den store fremtidsvisjon er at fiskeriforvaltningen, kystkommuner, fiskarlag, turistbedrifter, fiskeoppdrettere og oljeselskaper mfl. får opp øynene og ser hvilke muligheter dette kan gi/ha som et avbøtende tiltak, dvs. ved at man sår i havet, gjenskaper tareskogen osv. Forsøket i Hammerfest har vist at det er fulgt mulig å sette av egne «produksjonsfjorder, bukter» o.l for kunstige rev, med det mål og skape økt produksjon av tareskog og biologisk mangfold. 


\section{Hedensted kommune}

Hedensted Kommune lægger vægt på vækst gennem en bæredygtig udvikling på basis af dialog og nærdemokrati, hvor det overordnede mål er at fremme borgernes livskvalitet. Kommunen er en del af det østjyske storbybånd, præget af god infrastruktur og med landkommunens kvaliteter.

Hedensted Kommune har 46.000 indbyggere. Hedensted er hovedbyen med 11.000 beboere svarende til $25 \%$ af den samlede befolkning. $30 \%$ af indbyggerne bor i små landsbyer og landdistrikter, mens næsten halvdelen bor i mindre bysamfund og landsbyer. Befolkningstallet stiger støt med ca. $1 \%$ årligt.

Hedensted Kommune har et areal på ca. 550 km2. Kommunen er fattig på skov og anden natur - kun $14 \%$ af arealet, men et stort landbrugsareal og et relativt stort dyrehold.

\subsection{Prosjekt 1. Restaurering af Skjold Å og etablering af vådområde omkring Skjold Å.}

Skjold $\AA$ er beliggende på Juelsminde-halvøen og løber gennem noget af den bedste og dyreste landbrugsjord i Danmark. Åen er stærkt kanaliseret og dybtliggende med dårlige fysiske forhold og den afvander til den sårbare sydlige del af Kattegat i de indre danske farvande.

Syd for Bjerre Skov løber åen gennem et lavtliggende område på ca. 100 ha, som er effektivt afvandet på grund af det dybt gravede vandløb og dybtliggende drænrør og drængrøfter. $75 \%$ af arealet er intensivt drevet landbrugsjord, $25 \%$ er vedvarende græsarealer.

Dette område var i Vejle Amts Regionplan 2005 udlagt som lavbundsområde og potentielt vådområde. Der har siden 2001 været forhandlet med jordejerne om etablering af et vådområde på de 100 ha, men på grund af manglende økonomisk grundlag har projekttankerne været sat på stand by. Indtil de finansielle betingelser var til stede for at igangsætte projektet. 


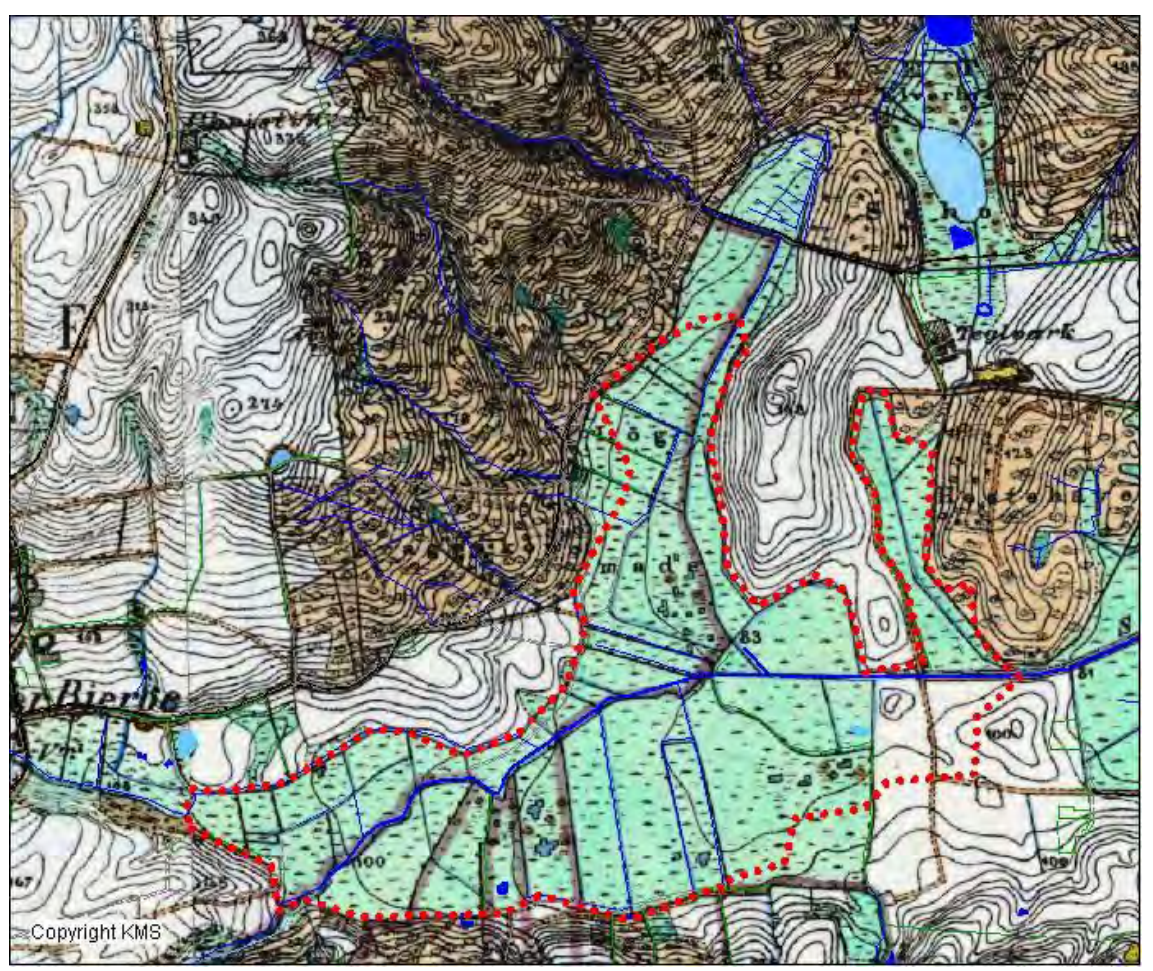

Fig. 15. Projektområde på målebordblad fra 1867.

Foto: Hedensted kommune.

\section{Projektbeskrivelse}

Gennem frivillige aftaler med jordejere og gennem nødvendig jordfordeling genskabes det øvre forløb af Skjold Å med en naturlig hydrologi.

Samtidig ønskes det sikret, at der kan ske tilbageholdelse af $\mathrm{N}$ og P fra landbrugsområderne i oplandet til åens øvre forløb. Det kan ske ved etablering af et nyt vådområde på 85 ha, herunder en sø på 18 ha syd for Bjerre Skov.

Restaureringen af åen skal skabe bedre og mere varierede fysiske forhold i Skjold Å. Det sker ved genslyngning af åen og udlægning af gydebanker i ån for at skabe egnede ynglebetingelser for havørred. Restaureringen skal samtidig skabe bedre livsbetingelser for vandløbsinsekter, som kræver rent vandmiljø.

Etableringen af søen skal ud over at tilbageholde $\mathrm{N}$ og P også forbedre forholdene for andefugle og vadefugle i kommunen. Søen kan samtidig indgå som et mål for kommunens forbedrede rekreative tilbud til befolkningen. 


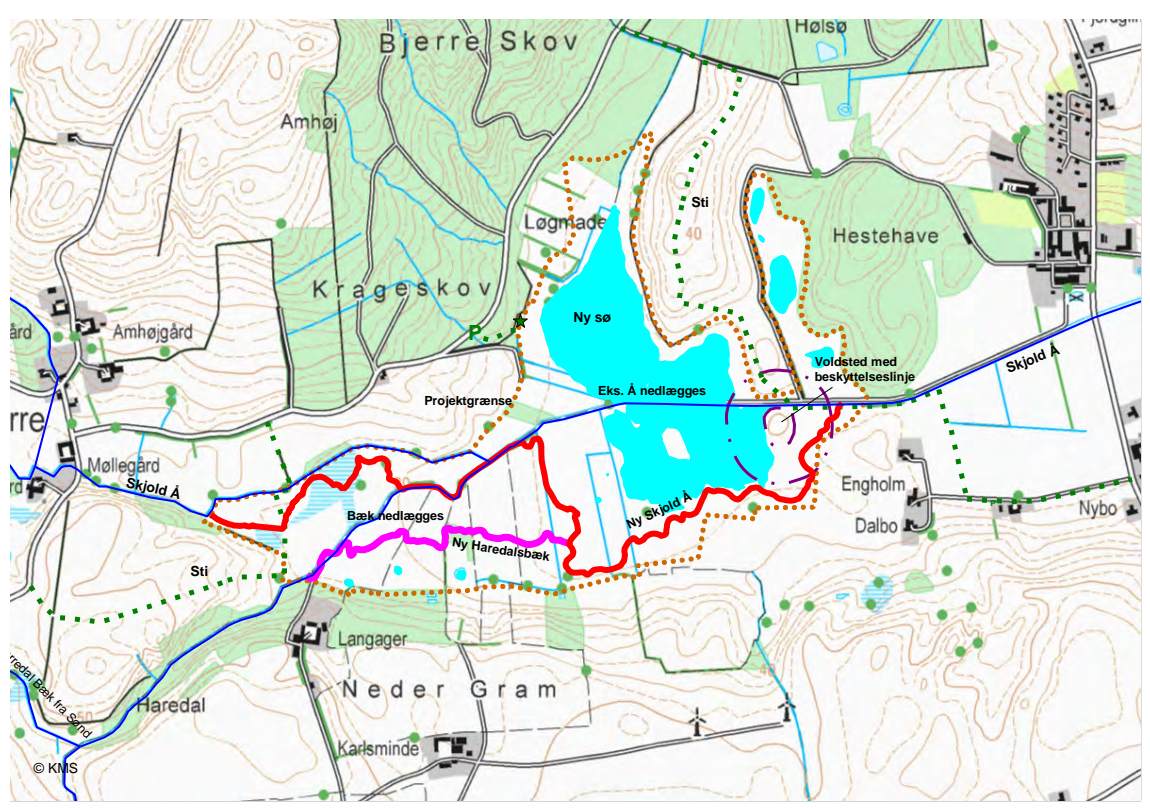

Fig. 16. Projektområde med ny sø (blå) og genslyngede vandløb (rød og magenta), stier (grøn punkteret streg), fugletårn (stjerne mellem Krageskov og søen).

Foto: Hedensted kommune.

\section{Samarbejdspartnere}

- Hedensted Kommune har været projektansvarlig og har blandt meget andet forhandlet erstatninger med involverede jordejere.

- Skov- og Naturstyrelsen har finansieret projektet og har på sidelinien fulgt projektudarbejdelsen og - udførelsen.

- Direktoratet for FødevareErhverv har forhandlet jordfordelingen med jordejerne.

- Landbrugsorganisationer har forhandlet på vegne af jordejerne.

- Grønt råd for Hedensted Kommune (debatforum for kommunalpolitikere og interesseorganisationer) er kommet med ideer til projektet.

- Jordejerne har med deres lokalkendskab bidraget med ideer til udformningen af projektet.

\section{Målsœetning}

Genskabelse af naturlig hydrologi ved at etablere stenstryg i Skjold $\AA$, der medfører hævning af vandstand på ca. 2 meter opstrøms i projektområdet.

Visse dræn lukkes og andre omlægges til åbne vandløb.

Visse grøfter lukkes og andre genslynges. Især de store vandløb Skjold $\AA$ og Haredalsbækken slynges og lægges højt i terrænet, således at de ofte går over deres bredder for afgivelse af næringsstof - især kvælstof.

Ny sø på ca. 18 ha, som opstår i projektområdets lavestliggende dele som følge af vandstandsstigningen, men som ikke gennemstrømmes af næringsholdigt vand, da Skjold Å forlægges uden om søen. 
Omkring søen og Skjold Å etableres på tidligere landbrugsjord ca. 69 ha vedvarende græsarealer med mulighed for vinteroversvømmelse og med mulighed for sommerafgræsning.

Der skabes ny og mere mangfoldig natur, som tilgodeser krav om god fysisk og miljømæssig kvalitet i det genslyngede vandløb og en god vandkvalitet i søen, hvilket tilgodeser en rig og varieret bestand af vand- og vadefugle.

Forbedring af et kulturmiljøområde ved øget beskyttelse og øget fortælleværdi.

Der sikres en større landskabsoplevelse med bedre tilgængelighed ved etablering af egnede stiforbindelser og udsigtspunkter (bl.a. fugletårn).

Begrænsning af høje maksimalafstrømninger nedstrøms i Skjold Å, da projektområdet vil give en forsinkelse i afstrømningen.

Begrænsning af tilledning af $\mathrm{N}$ og $\mathrm{P}$ fra landbrugsarealer til indre havområder med lav tolerance for næringsstoftilførsel.

Tiltag

Fakta om projektet:

- Projektområdet udgør i alt 87 hektar

- Heraf sø på 18 hektar med gennemsnitlig vanddybde på 0,80 meter. Største vanddybde ca. 1,50 meter.

- Søbund uddybet gennemsnitlig med $25 \mathrm{~cm}$ over 16 hektar svarende til $40.000 \mathrm{~m} 3$ jord. Formålet er at sikre målet om god vandkvalitet i søen ved at ophobet fosfor i det øverste jordlag fjernes fra den nye søbund. Endvidere vil den øgede dybde sikre åbent vandspejl en længere periode.

- De $40.000 \mathrm{~m} 3$ jord er alle udplaneret inden for et bælte på ca. 100 meter omkring søen og således at terrænet fortsat har hældning mod søen.

- Gravning af Ny Skjold Å og ny Haredalsbæk omfatter ca. 4,5 kilometer. Graves typisk højt i terrænet, særlig i den vestlige del, således at der sker hyppige oversvømmelser og dermed fjernelse af kvælstof fra vandet.

- Dertil kommer ca. $3 \mathrm{~km}$ mindre vandløb og sivegrøfter (ses ikke på kortet)

- Effekten af kvælstoffjernelsen forventes at blive op til 20 ton pr. år.

- Der etableres 14 nye rørbroer over grøfter.

- $0,7 \mathrm{~km}$ vandløb nedlægges

- $1,5 \mathrm{~km}$ nye drænledninger etableres til sikring af visse arealer uden for projektgrænsen, som fortsat skal være dyrkbare.

- Der lægges gydegrus i de nye vandløb

- Der afmærkes 3,5 km ny vandresti

- Der opstilles et fugletårn (ved grøn stjerne ved skovbrynet)

- Viden om et gammelt voldsted i projektområdet formidles. Vandresti føres omkring voldstedet 
- Til erstatninger udbetales ca. 13 mio. kr.

- Anlægsarbejde incl. fugletårn beløber sig til 2-3 mio. kr.

- Projektet er fuldfinansieret af Skov- og Naturstyrelsen.

Tiltagene er beskrevet i detailprojekt, som er godkendt lovgivningsmæssigt og forhandlet med lodsejerne.

Projektet har været i udbud blandt flere entreprenører. Entreprenøren har tæt kontakt til lodsejerne i anlægsperioden. Bygherren har tilsyn på arbejdet gennem projekteringsfirmaet. Fremdriften følges løbende ved afholdelse af byggemøder.

Gennemførelse i forhold til lodsejerne er sket ved ekspropriation af retten til at udføre projektet og ved udbetaling af erstatning for mistet jordværdi. Der er indgået forlig om erstatningerne.

\section{Resultater}

Entreprenørarbejdet startede den 1. august 2009 og er færdigt. Området blev officielt indviet den 21. juni 2010 og har fået det officielle navn Bjerre Engsø

Hedensted Kommune forestår ikke umiddelbart overvågning af det udførte projekt, ud over at finansiere en ugentlig optælling af områdets fugleliv, foretaget af Dansk Ornitologisk Forening.

Måling af effekt i forhold til kvælstoffjernelse sorterer under staten, som $i$ lignende projekter har bevilget penge til et års overvågning.

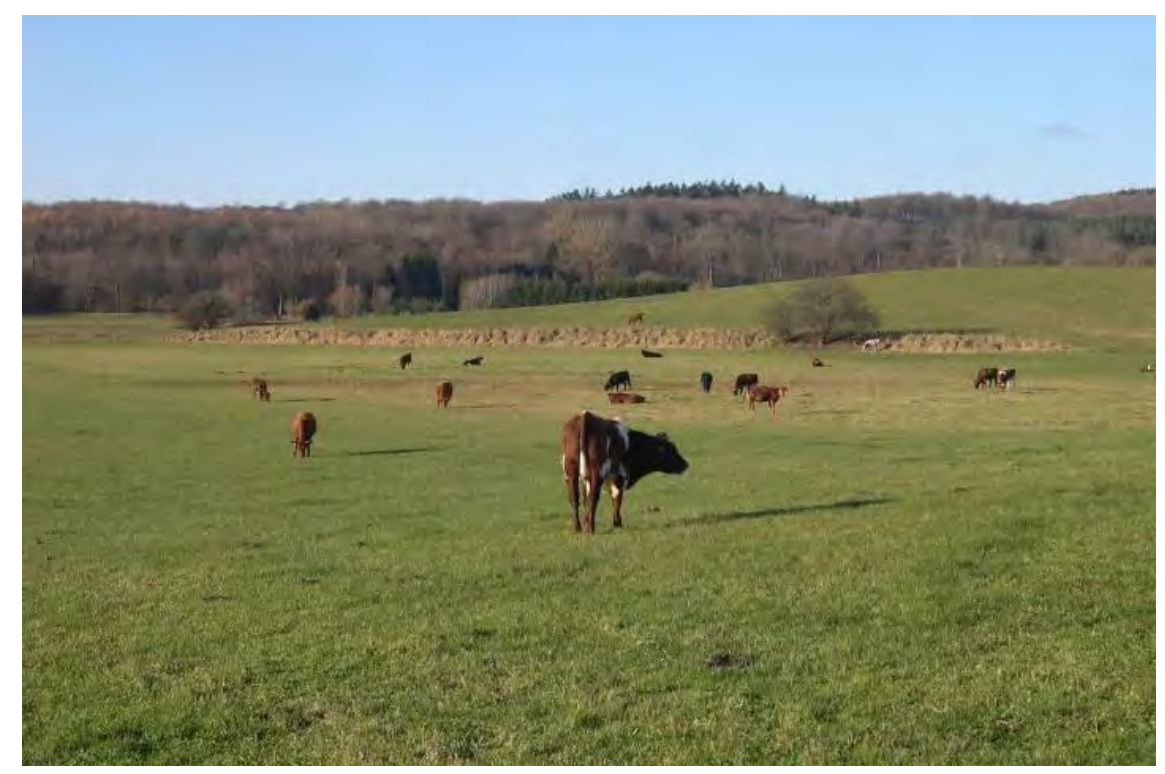

Fig.17. (13-11-2007) Grassende dyr på den kommende søbund. 


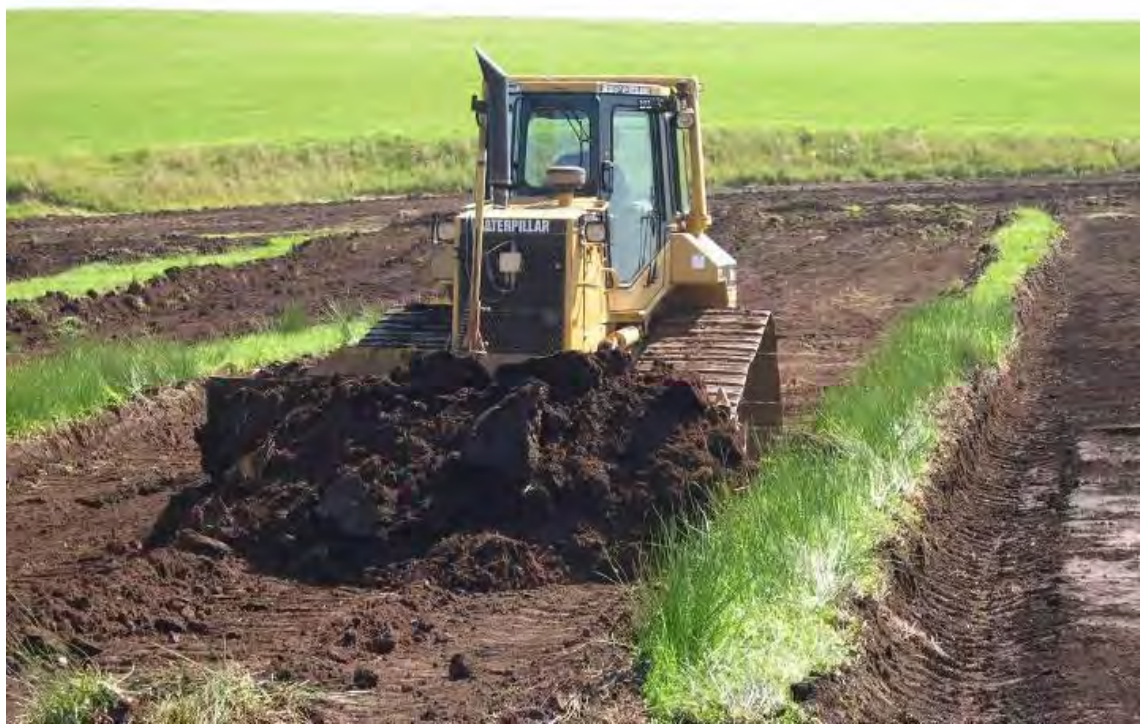

Fig. 18.(06-08-2009) Andre køer rømmer nceringsholdig muld af søbunden.

Foto: Hedensted kommune.

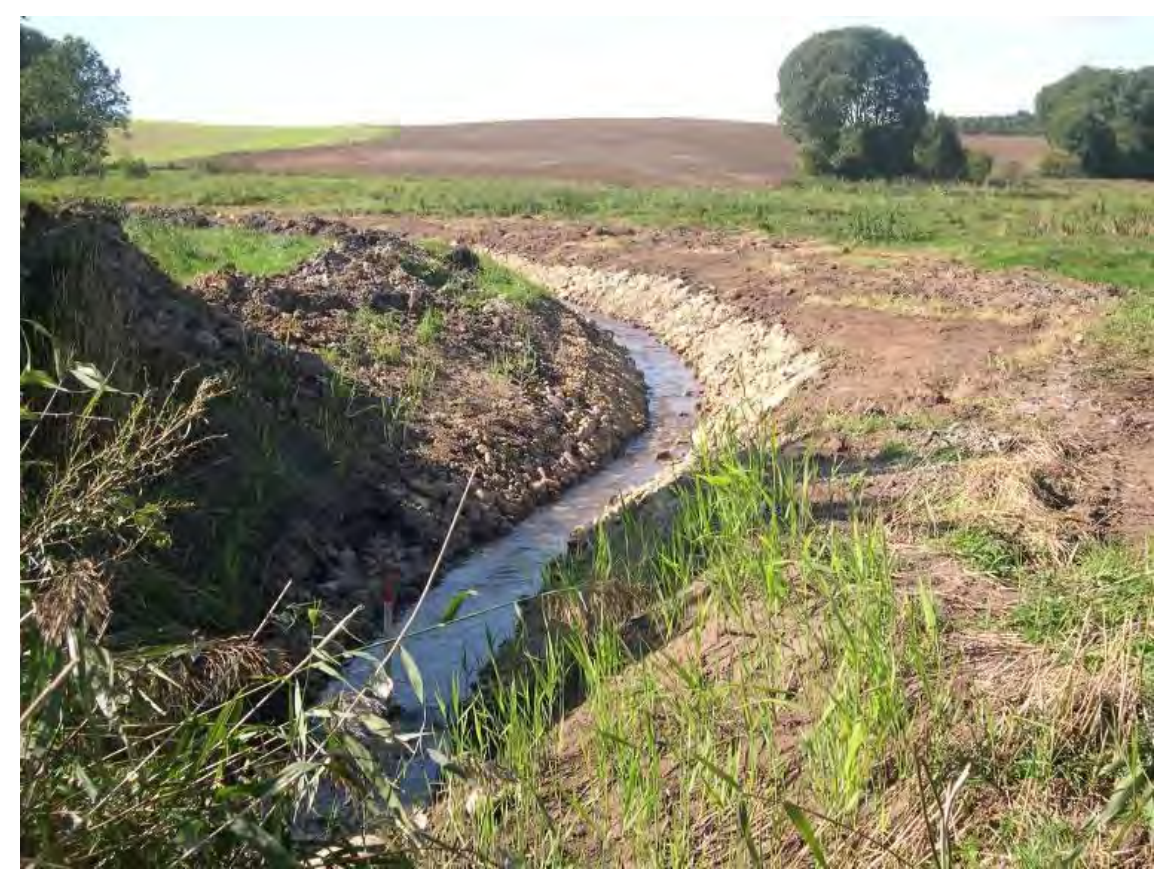

Fig. 19 (16-09-2009) Haredalsbckkens nye forløb.

Foto: Hedensted kommune. 


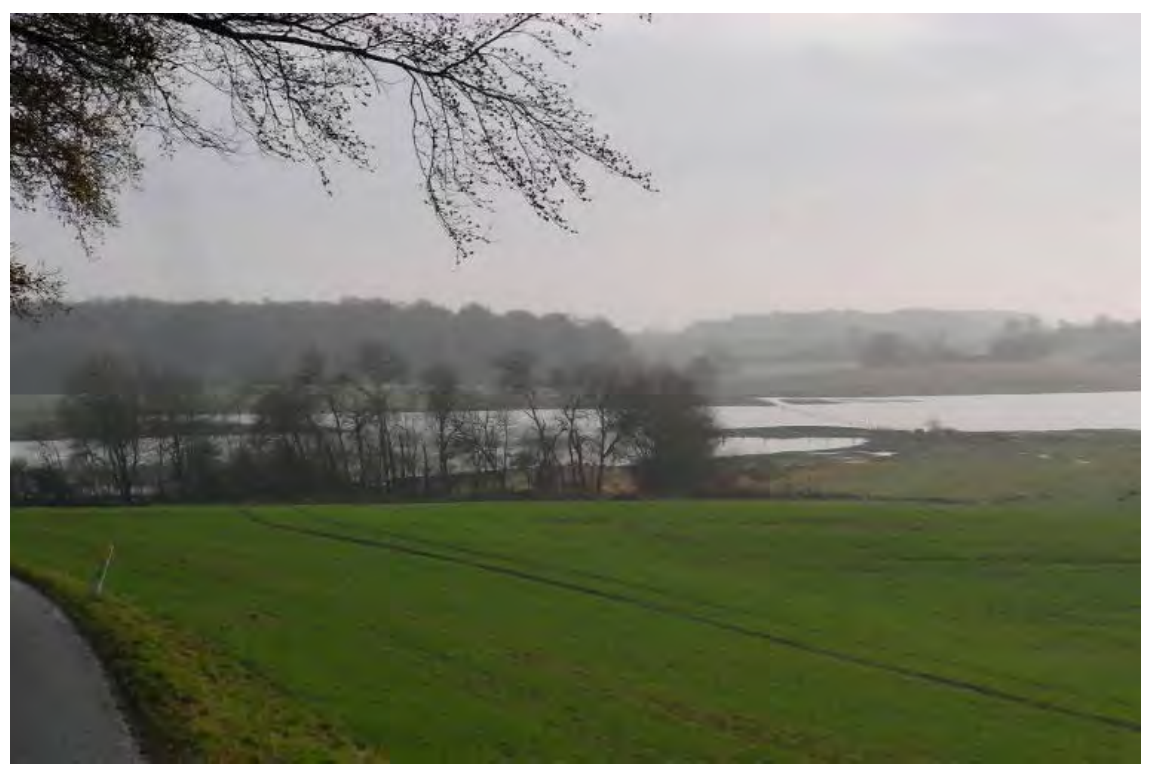

Fig. 20 (16-11-2009) Søen ncesten fyldt.

Foto: Hedensted kommune.

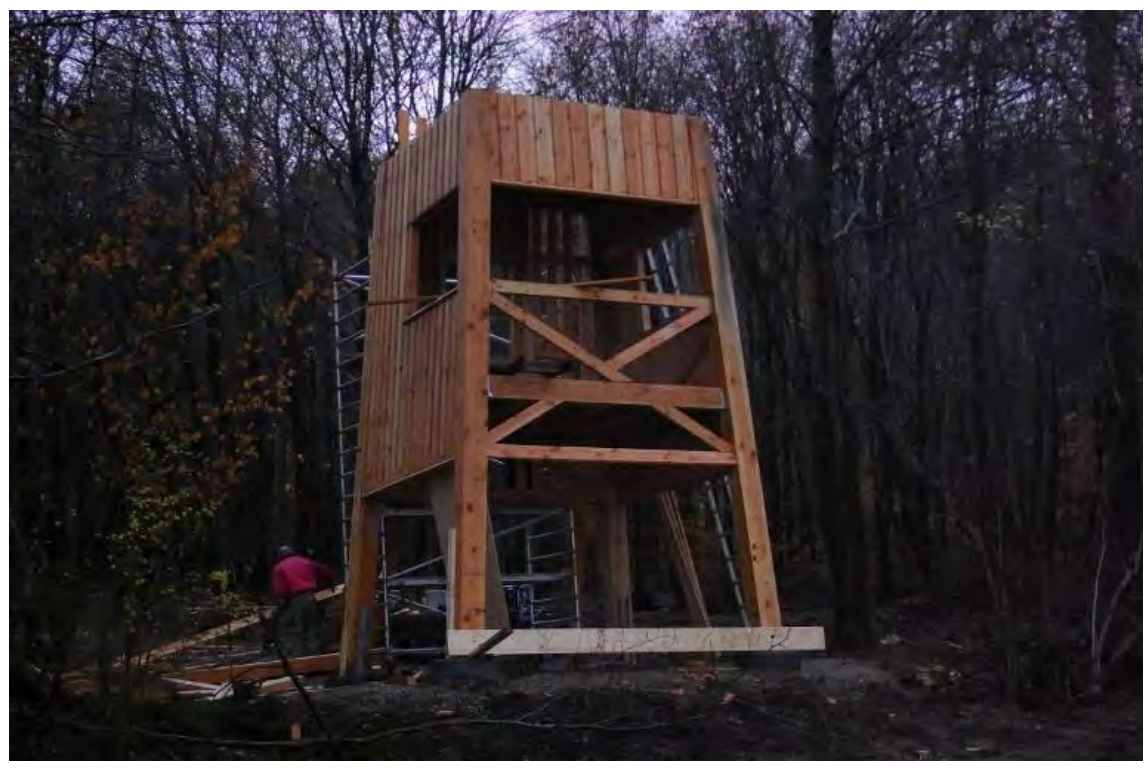

Fig. 21 (16-11-2009) Fugletårnet i skovbrynet vest for søen under konstruktion.

Foto: Hedensted kommune.

Fiskeundersøgelser og udvikling af ny natur vil være andre interessante temaer at tage op.

\section{Videre opfølgning}

For sikring af korrekt projektudførelse foretages 1 års gennemgang efter færdiggørelsen med entreprenøren og evt. fejl og mangler vil blive udbedret.

I øvrigt henvises til «resultater» 


\section{Erfaringer}

Succesfaktorer:

- Politisk vilje til at gennemføre ret radikale ændringer i et område, hvor der virkelig kan etableres et værdifuldt naturområde og opnås løsninger på miljøproblemer med kvælstof, fosfor og okker, samt skabes forbedring af dårligt fungerende vandløb.

- Åben proces i forhold til lodsejerne med flere fællesmøder og individuelle drøftelser.

- En god finansiering meget vigtig i et område med noget af Danmarks dyreste landbrugsjord.

- Tværgående samarbejde i den kommunale tekniske forvaltning for at se muligheder i forhold til flere involverede fagområder, således at projektet giver mest mulig gevinst.

- Anbefaling af - og besigtigelse med Grønt Råd og med borgergrupper.

- Helhedstænkning er et godt udgangspunkt ved planlægning og forberedelse af lignende projekter.

Er ideen god og formuleret i planlægningen skal man ikke være bange for at tage fat. Er der f.eks. finansieringsproblemer må man evt. midlertidig indstille arbejdet til «bedre» tider. Men erfaringen er, at der ofte vil vise sig muligheder for projekter af denne type hen af vejen. Borgerne efterspørger dem f.eks. hele tiden. Miljø- og naturproblemer står bestandig for at skulle løses.

Skjold Å projektet startede i 2001. Dvs. det tog 8 år, men resultatet blev nået.

\subsection{Prosjekt 2. Sikring af græsningsdrift/høslæt på de 30 botanisk mest værdifulde eng- og overdrevsarealer i Hedensted Kommune}

Stadig færre lodsejere har egne dyrehold til pleje eller drift af ejendommens naturområder. En række små, værdifulde naturområder med truede, fredede eller sjældne arter eller naturtyper er særligt udsatte for ikke længere at blive benyttet, så de lysåbne naturtyper ved længere tids manglende pleje/drift går tabt. I Hedensted Kommune har vi kendskab til 30 botanisk værdifulde små naturområder, som indeholder truede, sårbare, sjældne, fredede eller karakteristiske arter.

Projektet går ud på at sikre fremtidig nødvendig afgræsning eller høslæt, så de lysåbne naturtyper og deres biologiske mangfoldighed bevares. Projektet skal samtidig bevidstgøre ejerne om de naturkvaliteter de besidder. 


\section{Målscetning}

- sikre at der i 2008 eller 2009 indgås aftaler med alle lodsejere om fremtidig pleje eller drift på arealerne, så områdernes lysåbne vegetation sikres

- oprette/formidle børs, så kontakt mellem arealejere og dyreholdere lettes

- oprette og støtte lodsejernetværk (i samarbejde med landbrugskonsulenter)

- at jordejerne har interesse $\mathrm{i}$ at arealerne plejes

- at det lykkes at finde egnede og interesserede dyreholdere

- at jordejerne kan få økonomisk tilskud til miljøvenlig jordbrugsdrift fra staten/EU

\section{Tiltag og tidsramme}

Der er i foråret 2008 foretaget en undersøgelse af, hvilke af de 30 kendte, værdifulde naturområder i Hedensted Kommune, hvor der ikke længere foregår den pleje/drift, der er nødvendig for at opretholde en varieret flora, fauna eller funga. Det er undersøgt hvor driften/plejen er tilfredstillende og hvor der skal ske tilretning af driften. Hvor driften ikke længere foregår, er der foretaget vurdering af plejebehov og af, om arealets beliggenhed og størrelse gør det realistisk at få genoptaget afgræsning. Derefter undersøges ejernes mulighed for og ønske om drift af arealerne fremover. På grundlag af samtaler med ejerne, klarlægges behovet for aftaler om fremtidig drift, og om nødvendigt formidles der kontakt til dyreholdere med de mest egnede dyr til pleje af det konkrete areal. Der oprettes og understøttes et netværk mellem lodsejere i samarbejde med konsulenter fra Dansk LandbrugsRådgivning Østjylland (LRØ).

Der har i foråret-sommeren 2009 været dialog med LRØ om udarbejdelse af en kontraktform, som gør det lettere at indgå græsningsaftaler mellem kommunen og lodsejerne. Denne kontakt fortsætter resten af 2009 og videre ind i 2010 .

\section{Opnåede resultater}

Af de 30 undersøgte værdifulde naturområder var der god eller acceptabel drift på 18, der er på 4 af arealerne vurderet mulighed for forbedring af tilstanden gennem udvidelse af eksisterende græsningsareal.

12 værdifulde naturarealer ligger uden nogen form for drift. To af disse vurderes som for små og uhensigtsmæssigt placerede, at hegning og afgræsning ikke er realistisk. De resterende 10 arealer bliver inddraget i projektet.

Der er igangsat afgræsning på to botanisk værdifulde arealer, et engareal på 7,3 ha med engblomme (Trollius europaeus) og majgøgeurt (Dactylorhiza majalis). Arealet er blevet hegnet i 2009 og bliver græsset $\mathrm{i}$ to folde. Hegningen omfatter fire lodsejere. Dele af arealet har været afgræsset kontinuerligt, mens dele af arealet var under tilgroning. Arealet er beliggende i Natura 2000-område. 
Et eng- og overdrevsareal med majgøgeurt på 9,0 ha har ligget ubenyttet i ca. 10 år og er blevet hegnet i 2008 og bliver nu afgræsset i to folde. Arealerne omfatter to lodsejere. Hegningen er kombineret med etablering af offentlig stisystem langs den ene folds vest- og sydside.
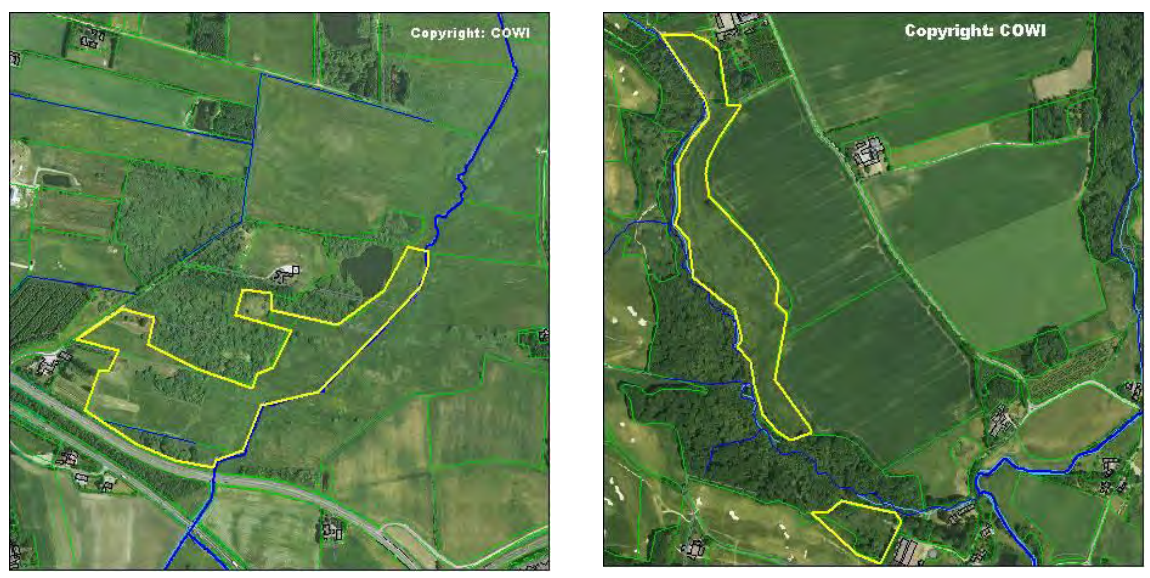

Fig. 22. To arealer hegnet 2008 og med grcesning $i 2009$.

Foto: Hedensted kommune.

Der er færdigforhandlet hegning, rydning og afgræsning på yderligere et areal på 12,5 ha, en lodsejer, også med anlagt stisystem ved og i foldene. Hegnslinier er ryddet. Opsætning af hegn sker i 2009, afgræsning fra 2010. Arealerne indeholder blandt andet majgøgeurt, skovgøgelilje (Plantanthera chlorantha) og hjertegræs (Briza media).

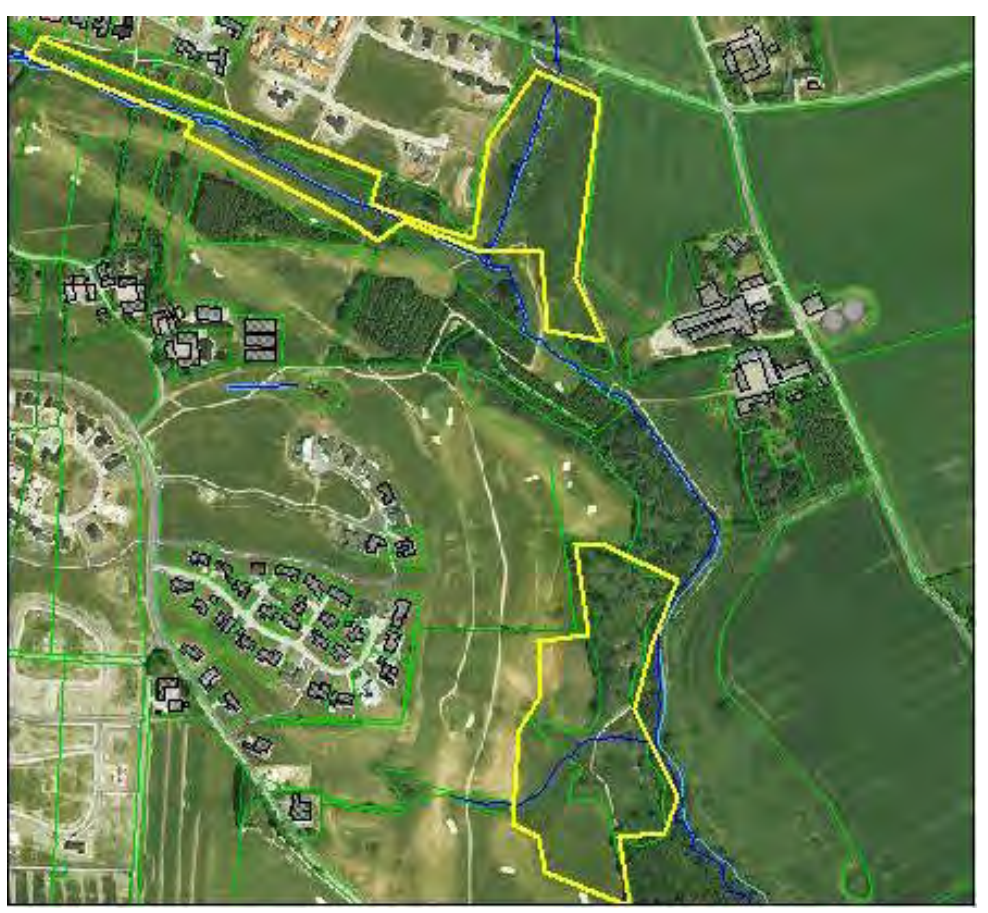

Fig. 23. Byncere arealer der hegnes og afgrcesses fra 2010.

Foto: Hedensted kommune. 
I samarbejde med LRØ vil der i 2010 blive indgået yderligere en række aftaler om hegning og afgræsning med relevante, positive lodsejere. Aftalerne kombineres om muligt med ansøgning om tilskud til miljøvenlig græsningsdrift på arealerne.

\section{Videre opfølgning}

Der forventes en tæt fremtidig dialog med de involverede lodsejere og dyreholdere for at gøre græsningsdriften/-plejen af længerevarende karakter og for at gøre lodsejerne bevidste om værdien af deres arealer og værdien af den aftale driftsform.

\section{Erfaringer og succesfaktorer}

Stor politisk interesse i et nært samarbejde mellem kommune, landbrugsorganisationerne og landmændene

Generelt stor interesse blandt lodsejerne til at få genoptaget en driftsform, som for den enkelte lodsejer ikke længere er rentabel eller praktisk mulig på grund af meget få græssende dyr til rådighed, men som ønskes for fortsat at bruge arealerne og for at fastholde landskabsstrøgene intakt. Konflikter mellem naturpleje og jagtinteresser hindrer genoptagelse af græsning på enkelte arealer.

Mulighed for at anvende græssende dyr fra gårde, som specialiserer sig $\mathrm{i}$ naturpleje via finansiering fra offentlige tilskudsordninger

Projektet har lidt under at det er en meget bureaukratisk proces at få indgået græsningsaftaler eller forpagtningsaftaler, der på den ene side sikrer finansiering af plejeprojektet og på den anden side ikke hindrer lodsejerens råderet over sin ejendom.

\subsection{Prosjekt 3. Certificering af skove nord for Vejle Fjord}

Langt den største biodiversitet i Danmark er knyttet til naturtypen «skov». Projektet retter sig mod at bevare og udvikle den biologiske mangfoldighed $\mathrm{i}$ de mest værdifulde skove i Hedensted Kommune - skovene langs nordsiden af Vejle Fjord. Skovene er udpeget som EF-fuglebeskyttelsområde og som EF-habitatområde.

Der rettedes i efteråret 2007 henvendelse til alle større skovejere med henblik på at få dem til at indgå aftale om FSC-certificering af deres skove.

Gennem certificering af skovene sikres en bæredygtig skovdrift, så den varierede skovnatur bevares og udvikles med mange forskellige skovnaturtyper nicher og substrater. Herved skabes en naturlig skovsuccession på lang sigt til gavn for flora, fauna og funga, som sikrer mod tab af biologisk mangfoldighed. 


\section{Målscetning}

Certificeringen af skovdriften skal medvirke til, at skovene i Natura 2000området ved Vejle Fjord kan leve op til målsætningen og forpligtigelsen om, at de NATURA 2000 udpegede arter og naturtyper kommer i en gunstig bevaringstilstand, og samtidig medvirke til at sikre skovejerne et økonomisk fundament for en bæredygtig skovdrift ved at CFC certificerede skovprodukter kan markedsføres i er højere prisleje end nu.

Det er målet at:

- flest mulige skovejere indgår aftale om certificering af deres skove

Projektet skal medvirke til en bæredygtig skovdrift ved at sikre:

- en naturlig skovsuccession

- en naturlig alderssammensætning af vedplanterne

- en naturlig artssammensætning af vedplanter

- at gamle overstandere efterlades til frøsætning og naturligt forfald

- at fladeafdrift afløses af plukhugst

- at foryngelse sker ved selvsåning

- at der løbende efterlades døde træer, såvel faldne som stående til naturlig omsætning

\section{Tiltag gennemført}

Der er afholdt første møde med de væsentlige skovejere i området med henblik på at orientere skovejerne om kommunens ideer og afstemme forventninger og succeskriterier.

Skovejerne er blevet orienteret om de forventede krav, der vil blive stillet til dem for at deres skove i Natura 2000 området kan opnå en gunstig bevaringstilstand og hvordan dette projekt kan lette skovejernes arbejde med at leve op til disse krav.

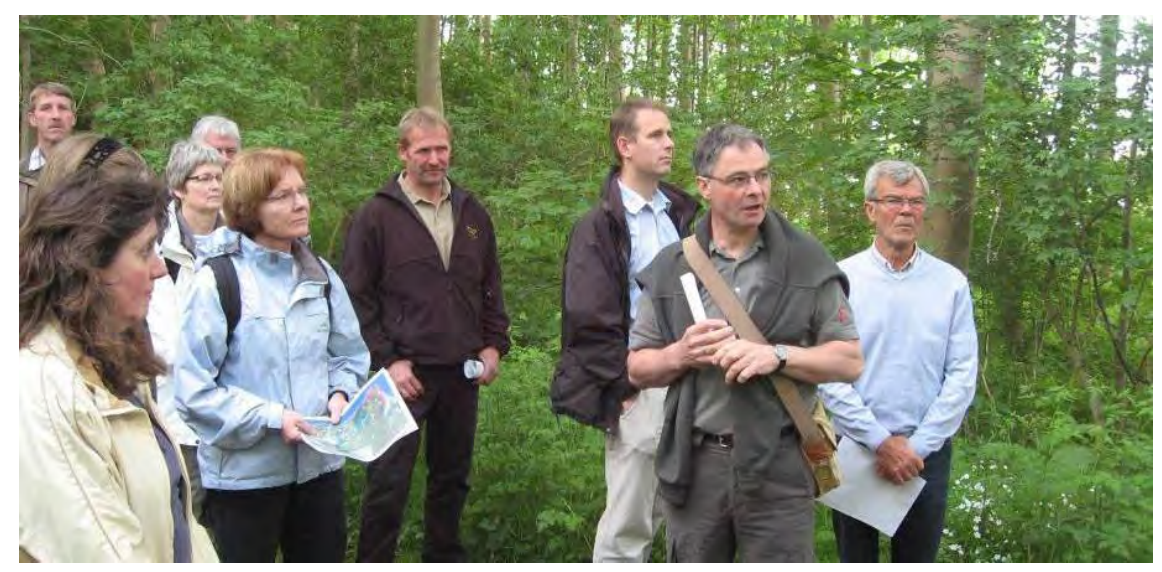

Fig. 24. Skovfoged Asger Thyge Pedersen beretter om naturlig foryngelse af Fraxinus-skov og problemerne med indvandring af Acer pseudoplatanus, som hindrer gunstig bevaringstilstand af Fraxinus-skoven.

Foto: Hedensted kommune. 


\section{Opnåede resultater}

Den danske stats Natura 2000-målsætninger skal danne grundlag for de handleplaner, der skal udarbejdes med henblik på at bringe skovene i en gunstig bevaringstilstand. Disse målsætninger var lovet færdige i oktober 2008, men forventes nu at komme i offentlig høring i december 2010.

Der var ikke umiddelbar stemning hos skovejerne for at certificere skovdriften på nuværende tidspunkt. Derimod var der bred interesse for at fortsætte kontakten, og Hedensted Kommune blev opfordret til at følge dette første møde op med yderligere møder og kontakter.

I 2010 er dialogen derfor fortsat ved at kommunen har deltaget i et møde, arrangeret af områdets væsentligste skovejere, og endnu et møde planlægges til september 2010.

Projektet bør tilrettes, så det ikke udelukkende retter sig mod certificering af skovdrift, men at der findes løsninger der tilpasses den enkelte ejers ønsker og behov.

Ud over en positiv stemning blandt skovejerne ved mødet i 2007 er der ikke opnået resultater i dette projekt ved indgangen til 2010.

\section{Videre opfølgning}

Det er kommunens plan at fortsætte projektet i 2010, når resultaterne fra statens Natura 2000 målsætning kendes.

Skovejerne er løbende holdt orienteret om, at projektets fremdrift afventer Statens udmelding om mål og indsats for NATURA 2000 skovnatur.

\section{Erfaringer}

Skovejerne gav udtryk for at have manglet henvendelse fra det offentlige om, hvordan de tackler de forventede krav til driften af skovene i Natura 2000 området.

Den foreløbige aftale med skovejerne går på, at kommunen varetager de «bløde økologiske» værdier og skovdyrkerforeningen de «hårde økonomiske» værdier i det fremtidige samarbejde.

\subsection{Prosjekt 4. Den Klimatilpassede Kommuneplan for Hedensted Kommune}

Udarbejde en klimatilpasset kommuneplan, som sikrer det nødvendige grundlag og den nødvendige plads, så den naturlige flora og fauna kan udvikle og tilpasse sig de fremtidige klimatiske forhold.

\section{Målscetning i forhold til biologisk mangfoldighed}

- at identificere områder, der forventes at blive mest påvirket af effekterne af klimaforandringerne frem mod år 2100. 
- at reservere arealer, der forventes at blive væsentligt påvirket af øget nedbør, højere vandstand og mere ekstreme vejrsituationer, til udvikling af en mere sammenhængende natur.

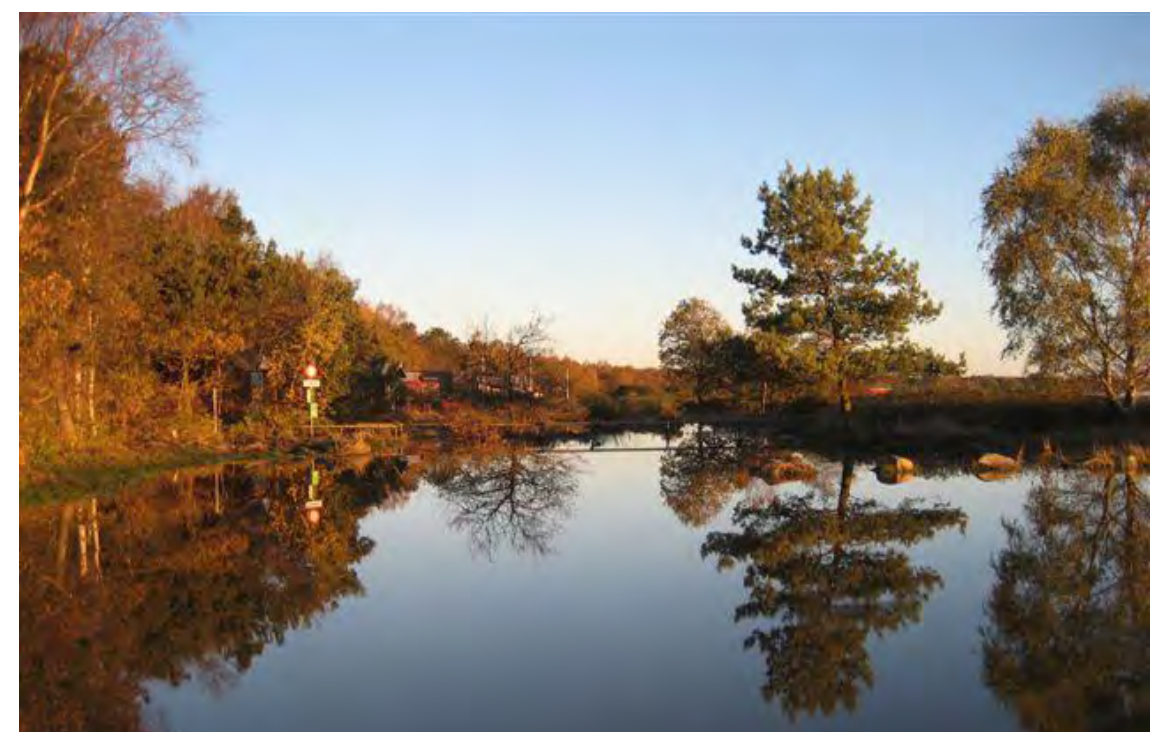

Fig. 25. Oversvømmelser ved kysten skal håndteres ved at afveje behovet for at beskytte eksisterende vardier, og for at udvikle en dynamisk kystnatur. I det åbne land skal naturen som hovedregel kunne udvikle sig dynamisk.

Foto: Hedensted kommune.

Tiltag og tidsramme

Projektet Den Klimatilpassede Kommuneplan er afviklet i årene 2008 og 2009.

Der er opbygget en hydraulisk model til beregning af oversvømmelser fra vandløb og ved havet.

Der er gennemført beregninger af oversvømmelser i år 2100 ved 2 klimascenarier, henholdsvis IPPC's scenarie A2 og et A1 scenarie svarende til den øvre usikkkerhedsgrænse for A2 scenariet.

Der er gennemført kortlægning af områder, der må forventes berørt væsentligt af en højere nedbør og af en højere vandstand i havet.

Der er gennemført en kortlægning af arealer, der risikerer en drændybde $<1 / 2$ og 1 meter

Der er gennemført kortlægning af områder, der må forventes berørt væsentligt af en højere grundvandsstand.

\section{Opnåede resultater}

Den Klimatilpassede Kommuneplan er selvstændigt afrapporteret ved udgangen af 2009.

Der er indarbejdet retningslinjer for arealanvendelse af klimatilpasningsområder i Kommuneplan 2009-21, der forventes vedtaget i december 2009. 
Oversvømmelsestruede arealer reserves i kommuneplanen til natur og vådområder ved ændring af den eksisterende arealanvendelse.

Grunden er lagt til konkret planlægning og konkrete projekter som kan bidrage til en mere dynamisk natur.

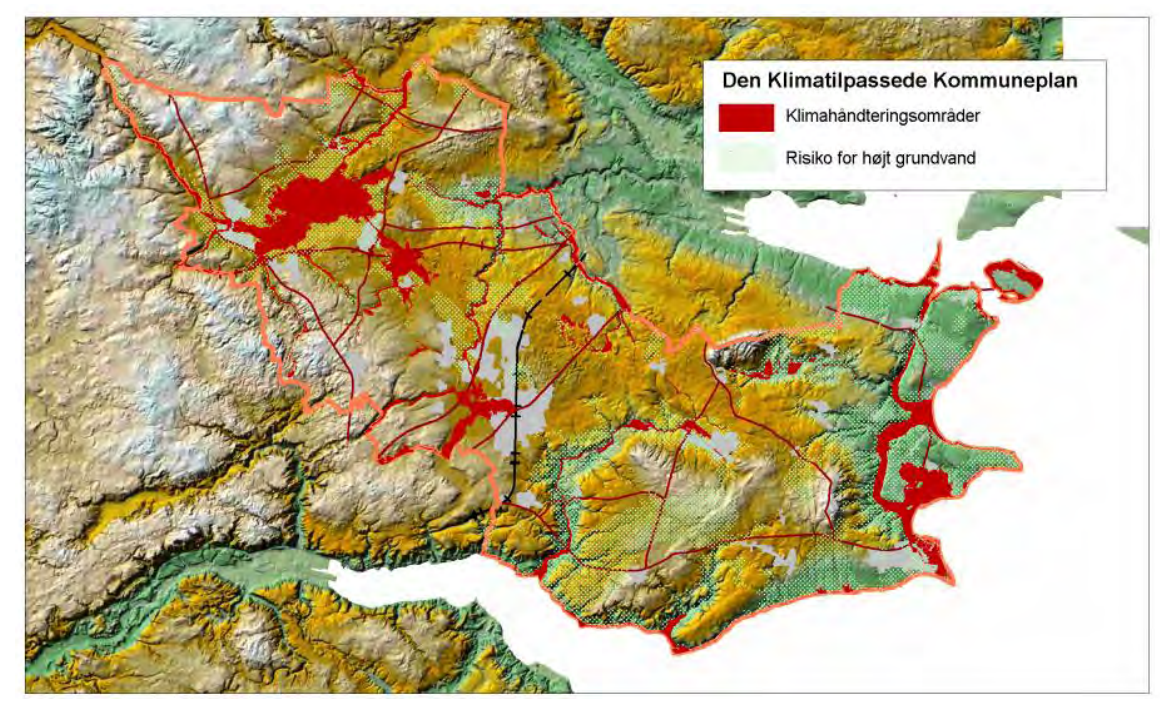

Fig. 26. Naturgenopretning er oplagt i langt størsteparten af områderne der risikerer oversvømmelser i fremtiden

\section{Indikatorer og måleparameter}

Måleparameter for succes er omfanget af arealer, der er truet oversvømmelse, hvor der etableres en varieret natur.

\section{Videre opfølgning}

Naturgenopretning af arealer, der på sigt er truet af oversvømmelser, vil fremover indgå som en integreret del af projekter, der har andre formål. Det gælder f. eks. projekter der har til formål at begrænse udledning af kvælstof (N) til vandmiljøet, og projekter, der har til formål at skabe nye bolig- eller erhvervsområder.

\section{Erfaringer}

Vi har erfaret, at der stedse skal være fokus på udvikling af organisationen, projektledelse og styring. Forløbet har været noget kaotisk. Det har der været 4 hovedårsager til:

Det digitale grundlag for den hydrauliske model var ikke på plads ved projektstart.

Udskiftning af personer i projektgruppen og hos konsulenter koster sammenhæng.

Tidsforbruget til at metodeudvikle og gennemføre den hydrauliske model var underestimeret. Det faglige grundlag har derfor ikke altid været på plads ved de øvrige dele af projektet.

Der har ikke været tilstrækkeligt fokus på det organisatoriske, f. eks at skabe fælles forståelse for projektets mål ved personudskiftninger. 


\section{Laering}

Der er grundlag for at løfte en del af 2010 målet om stop for tab af biologisk mangfoldighed gennem tværfagligt samarbejde f. eks. om byudvikling, vandafledning og vandmiljø.

Grundig og vedvarende diskussioner i det kommunalpolitiske forum, i administrationen og mellem politikere og administration om klimaudfordringen, sammenhængen til andre til andre fag- og opgavefelter er et meget vigtigt grundlag for at afdække det kommunale interessesfelt, og for at skabe bred politisk og administrativ opbakning.

Det er svært at samarbejde med borgerne om abstrakte forhold. Det er meget nemmere at samarbejde om meget konkrete projekter der resulterer $\mathrm{i}$ forandringer indenfor kortere tid.

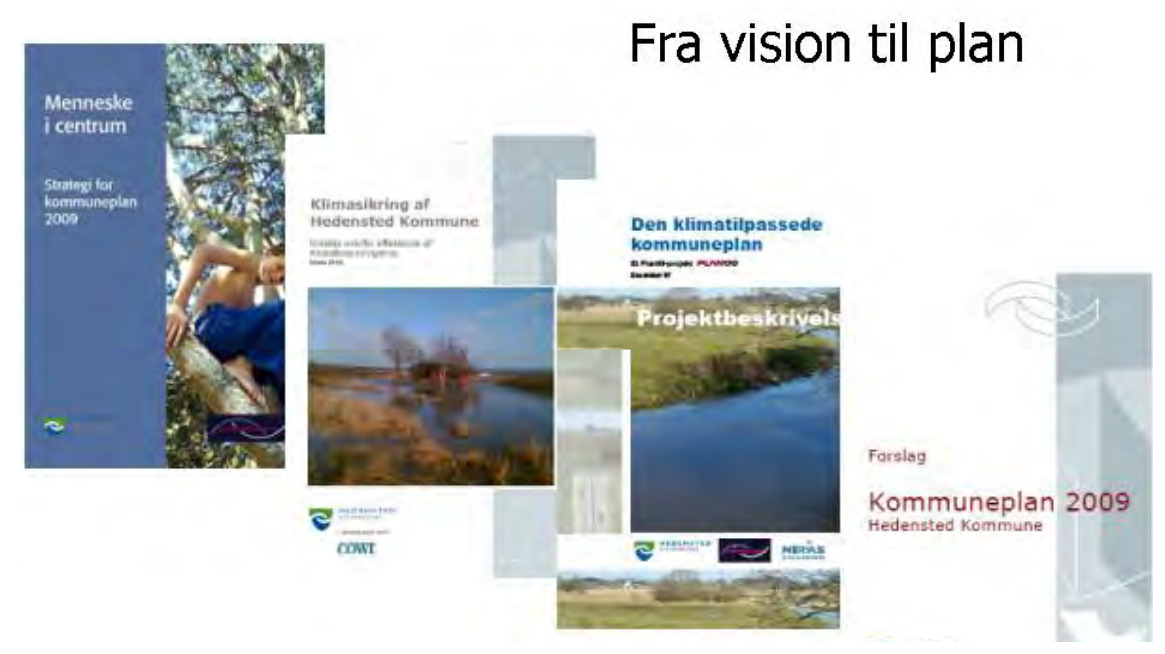

Fig. 27. Visioner kan virkeliggøres med en strategisk tilgang

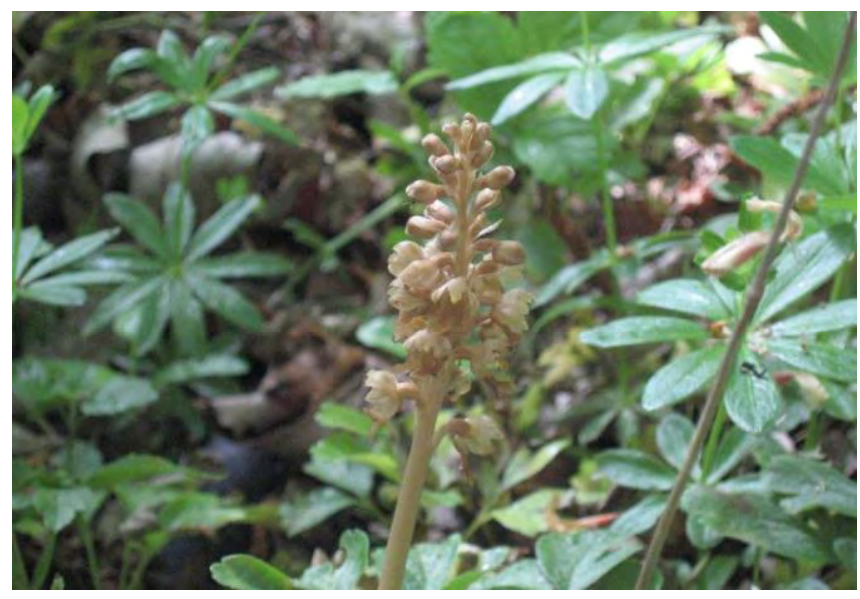

Fig. 28. Rederod (Neottia nidus-avis) i skovbund med Skovmcerke (Galium odoratum) i lysåben løvskov ved Vejle Fjord.

Foto: Hedensted kommune. 


\section{Herning kommune}

Herning Kommune ligger midt i Jylland vest for den jyske højderyg. Den vestjyske natur er præget af menneskets aktiviteter og naturtyper er opstået som følge her af: Lyngheder, enge og græsningskrat. Skove er gennem tiderne fældet og åløb er rettet ud for at skabe landbrugsjord. Brunkulslejer og plantagedrift præger også landskabet. Kommunen har altid haft fokus på miljø og natur. Helt overordnet stiller vi nogle høje miljøkrav til os selv.

Kommunen har et areal på $1323 \mathrm{~km}^{2}$, ca. 84.000 indbyggere, $118 \mathrm{~km}^{2}$ beskyttede arealer, $10 \mathrm{~km}^{2}$ søer, $890 \mathrm{~km}$ vandløb og 10-15.000 arter af dyr og planter.

\subsection{Projekt 1. Naturpolitik i Herning Kommune}

Vi vil stoppe tilbagegangen i den biologiske mangfoldighed og sikre fremtidige generationer en varieret natur. Landskabets og naturens fortællinger anvendes som ramme for oplevelser og fælles værdier for borgernes trivsel og velfærd samt i udviklingen af kommunens naturværdier.

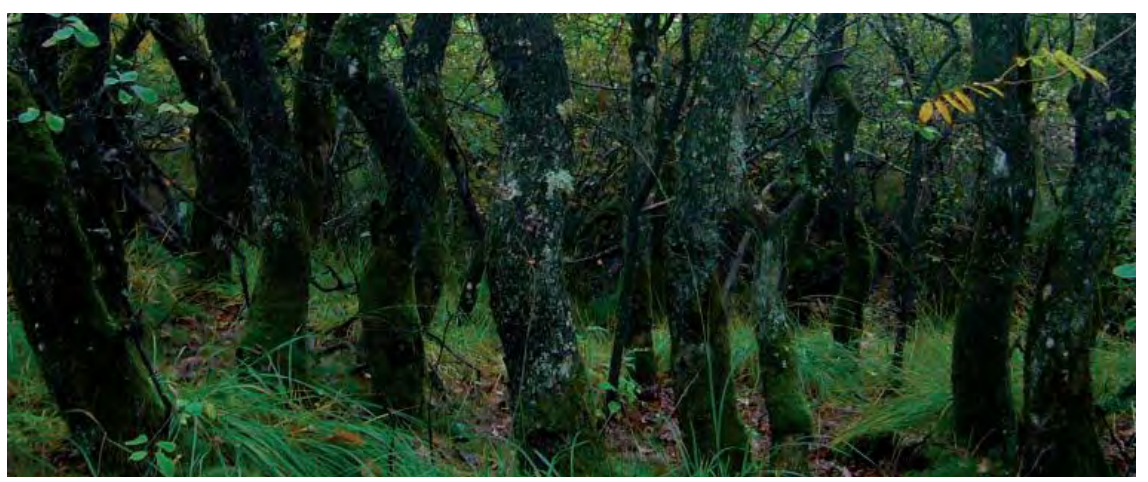

Fig. 29. Egekrat i Løvbakkerne.

Foto:Herning kommune.

\section{Projektbeskrivelse}

Det blev politisk besluttet $\mathrm{i}$ byrådet, at der skulle udarbejdes en sammenhængende naturpolitik for Herning Kommune. Der blev derfor nedsat en projektgruppe til at udarbejde naturpolitikken for Herning Kommune.

Naturpolitikken udarbejdes som følge af nye kommunale opgaver på natur- og miljøområdet i samarbejde med borgere, organisationer og Grønt Råd for Herning Kommune. Naturpolitikken skal konkret være en samlet politik for, hvordan naturen i kommunen fastholdes og udvikles samt for, hvordan nedgangen i biodiversiteten standses. Desuden udarbejdes naturpo- 
litikken for at sætte fokus på, hvordan kommunen selv og sammen med borgere/lodsejere kan medvirke til at bevare og udvikle naturen. Disse forhold betyder at den biologiske mangfoldighed og naturen prioriteres højt i forhold til anden planlægning, og at man i Herning Kommune vil mere end lovens krav siger.

Aktørerne i denne proces er projektgruppen for Naturpolitik, med viden om natur, miljø og borgerinddragelse. Målgruppe og samarbejdspartnere er skoler, daginstitutioner, borger, foreninger, virksomheder samt kommunens andre forvaltninger og fagområder. Ekstraordinært er der nedsat en følgegruppe, Grønt Råd, som skal følge, rådgive og kommentere processen for naturpolitikken og de forskellige arrangementer samt essentielle dokumenter.

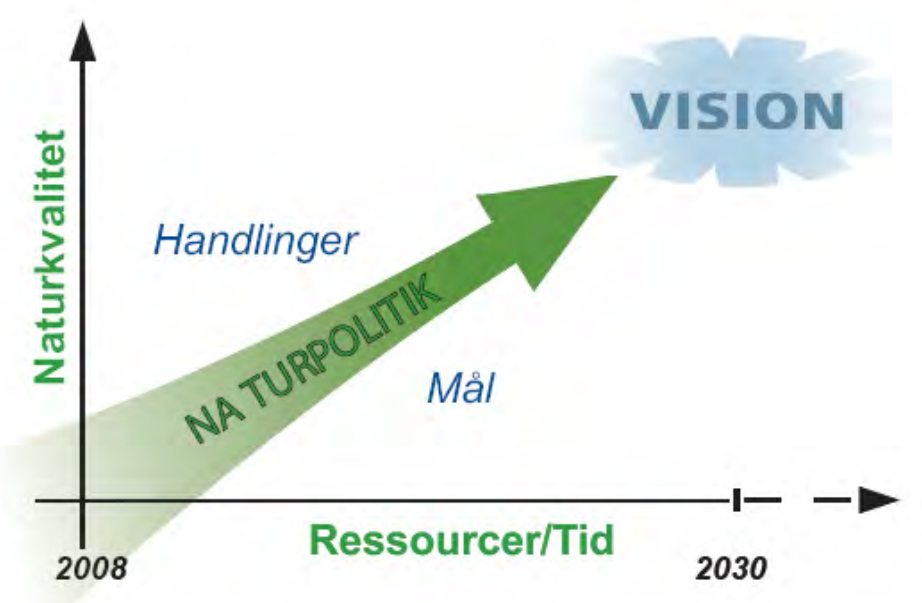

Fig. 30. Fig.uren viser vejen frem mod Byrådets vision om «at sikre fremtidige generationer en varieret natur og landskaber med plads til udvikling og oplevelse».

\section{Målscetning}

- Naturpolitikken skal fastsætte:

- Rammer for en fremtidig og bæredygtig arealanvendelse af det åbne land og bynære naturområder.

- Mere og aktiv inddragelse af politikere og borgere ift benyttelse og beskyttelse af naturen.

- Indarbejdelse af målsætninger og retningslinjer for udvalgte emner i kommuneplanen.

- Mål og visioner for biodiversitet og naturen

\section{Gennemførte tiltag}

Der er i november 2007 gennemført følgende. To dialogmøder med borgere - et i den nordlige del af Herning Kommune, Hodsager og et i den sydlige del af Herning Kommune, Skarrild - samt en tur med Teknik og Miljøudvalget. Fotokonkurrence og statusbeskrivelse af landskabet og naturen i 8 landskabsområder samt ca. 20 fokusområder i Herning kommune er udført. 
Byrådet har ligeledes været inddraget med henblik på at få en debat om det hidtidige arbejde i form af natursyn og naturvision samt en tilkendegivelse af, at det er et ambitiøst fremtidsscenarie for Herning Kommunes Naturpolitik, der skal iværksættes.

Udarbejdelsen af naturpolitikken blev færdige i sommeren 2008. Der er udarbejdet 3 hoveddokumenter.

- En statusrapport, som er en landskabs- og naturanalyse.

- Et handlekatalog, som er en analyse af handle- og udviklingsmuligheder.

- Den endelig naturpolitik med en handleplan og retningslinjer til kommuneplanen.

I forbindelse med naturpolitikken blev der udarbejdet en pixi udgave heraf. Pixi udgaven er blevet udsendt til samtlige (ca. 5000) husstande på landet efterfulgt af pressedækning, som også blev færdig i 2008.

Alle projektgrupper i handlingsplanen for 2009 er gået i gang med deres projekter. Der bliver fulgt op på mål indenfor de 10 indsatsområder på kvartalsmæssige møder i en koordineringsgruppe bestående af projektledere for alle projekterne.

Der er lavet nye vandhuller til padderne stor vandsalamander og løgfrø, udført naturpleje i Haderis ådal, lavet madpakkehus på Præstbjerg og lavet pleje af gravhøje.

\section{Videre opfølgning}

Herning Kommune udarbejder årligt et grønt regnskab. Her er det vores hensigt at få en række indikatorer ind omkring 2010 målene, det kunne være antal og udvikling i landbrugets naturplaner, eller fokus på bestemte arter og naturtyper.

Men også borgerhenvendelser samt kendskab til naturpolitikken er en vigtig indikator for omfanget af borgerinddragelse og dennes effekt.

Endeligt en øgning af naturarealer, som vil bidrage positivt til beskyttelse af arter og en variation $i$ arter. Endvidere er en styrket indsats for bæredygtig udvikling et fælles lokalt ansvar en vigtig overordnet medvirkende faktor til at bevare den biologiske mangfoldighed. 


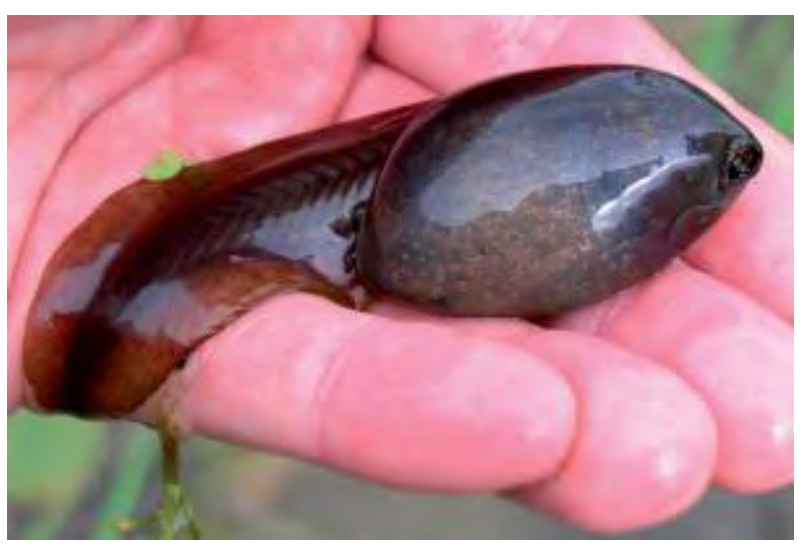

Fig. 31. Haletudse af løgfrø.

Foto: Herning kommune.

Der er i de kommende år afsat 1 mill. kroner per år til at gennemføre politikken.

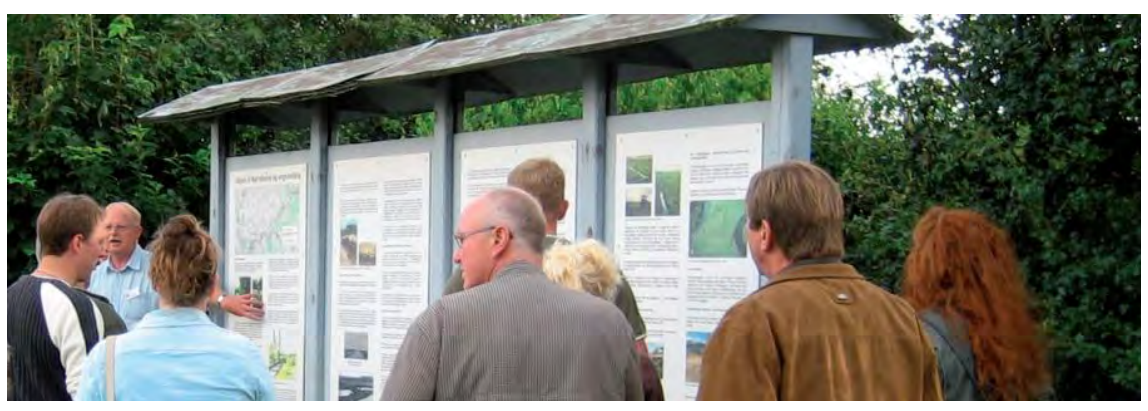

Fig.32 Informasjonstavler studeres.

Foto:Herning kommune.

\section{Erfaringer}

Visionen for naturpolitikken skal konkretiseres gennem en række indsatsområder $\mathrm{g}$ initiativer, $\mathrm{og}$ herunder er:

- Sikring og styrkelse af kommunens eksisterende naturværdier gennem pleje og genopretning

- Sikring af levevilkår og levesteder for hjemhørende planter og dyr

- Genskabelse af naturens våde levesteder

- Skabelse af større sammenhængende naturområder gennem planlægning og forvaltning af spredningskorridorer, samt sikring af sammenhængende natur på tværs af kommunegrænser gennem kommunalt og tværfagligt samarbejde

- Sikring af nærhed til natur og oplevelser for Hernings borgere og besøgende

- Fastholdelse og formidling af vor særegne natur- og landskabsfortælling

- Mere fokus på biologisk mangfoldighed gennem netværkssamarbejde i Dogme 2000, nordisk samarbejde, Nationalpark Skjern Å m.m. 
Det er vigtigt at inddrage borgenes egne ønsker i forbindelse med naturoplevelser og behov samt deres handlemuligheder og handlekompetence $\mathrm{i}$ forhold til beskyttelse og benyttelse af naturen i hverdagen.

Et godt samarbejde med borger, foreninger, grupper og virksomheder giver et fælles politisk og kommunalt engagement og ejerskab til vores naturpolitik

\subsection{Projekt 2. Laksehandlingsplan i Skjern $\AA$-systemet}

Laksen har været i Danmark siden sidste istid og har tilpasset sig de danske vandløb, efterhånden som de formede sig. Genetisk set er Skjern Å laksen unik og kan nemt skelnes fra andre laksestammer i både Danmark og det øvrige Norden.

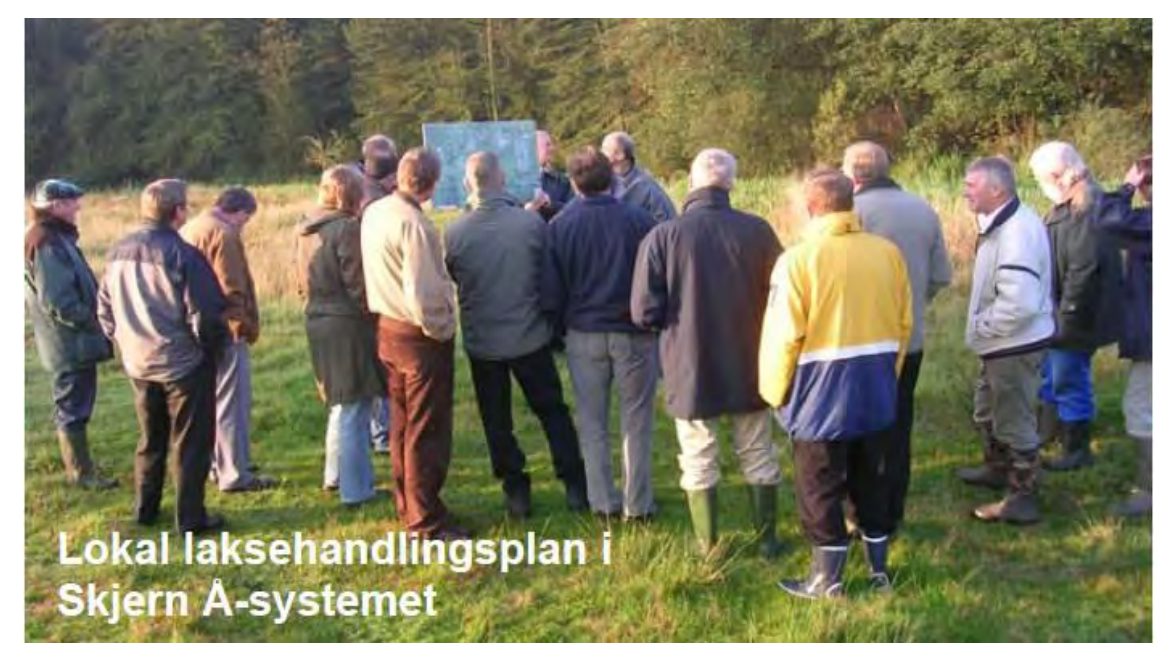

Fig. 33 Lodsejere, politikere og embedsmond mødes i det fri for at diskutere mulige løsninger til at fjerne en fauna spcerring.

Foto:Herning kommune.

\section{Projektbeskrivelse}

Den danske laks skal reddes. Ikke kun fordi vi har forpligtet os internationalt, men fordi den bringer en lang række positive følgevirkninger med sig. Laksen stiller store krav til sine levesteder og er derfor en glimrende miljøindikator. Har laksen det godt, har mange andre dyr og planter det også godt, nogle dog kun indtil de bliver spist.

Med det store naturgenopretningsprojekt i den nedre del af Skjern Å, er der skabt mulighed for at laksen får betydeligt bedre levevilkår i fremtiden. Der er dog stadig problemer længere oppe i Skjern Å. Her betyder opstemninger ved dambrug og vandkraftsværker, at det er svært for både den voksne gydemodne laks, der skal nå de gode gydepladser, og de unge laks, der trækker mod havet.

Den fremtidige dambrugsproduktion forventes i større grad at gøre brug af ny teknologi, der sikrer bedre kontrol og stabilitet i produktionen. Dette 
medfører at dambrugene ikke behøves opstemninger i vandløbet. Der hvor det ikke er muligt at bruge den nye teknologi er det nødvendigt at sikre fiskepassagen på anden vis.

I Herning Kommune er der nogle helt specielle forhold omkring gamle kulturhistoriske minder. Det drejer sig om to engvandingskanaler, der blev anlagt ved Skjern Å i 1870erne. En række opstemninger sikrer kanalernes vandføring, men betyder også at blandt andet laksens vandring forstyrres. Når den mulige løsning er fundet, skal udgifterne fordeles og først her efter kan der igen skabes fri passage.

\section{Målscetning}

Målet er at finde de bedste muligheder for at sikre laksens levesteder i lokalområdet. Dette giver både opbakning og forståelse for de løsninger der vælges.

Den sjældne lampret, vil også få glæde af ændringer i forholdene omkring kanaler og dambrug. Og kommer der flere fisk, får både odder og isfugl det bedre.

\section{Gennemførte tiltag}

Herning og Ikast-Brande Kommuner har i samarbejde fået udarbejdet 2 løsningsforslag til sikring af fiskepassage ved Sandfeld-Hesselvig Kanal. Der er valgt en strygløsning med gydebanker og hvilebassiner, som forventes udført i starten af 2010. Projektet vil koste ca. 4. mill. kr.

Vandløbspleje i tilløb til Skjern Å med blandt andet udlægning af gydegrus og reduktion af tilførsel af sand.

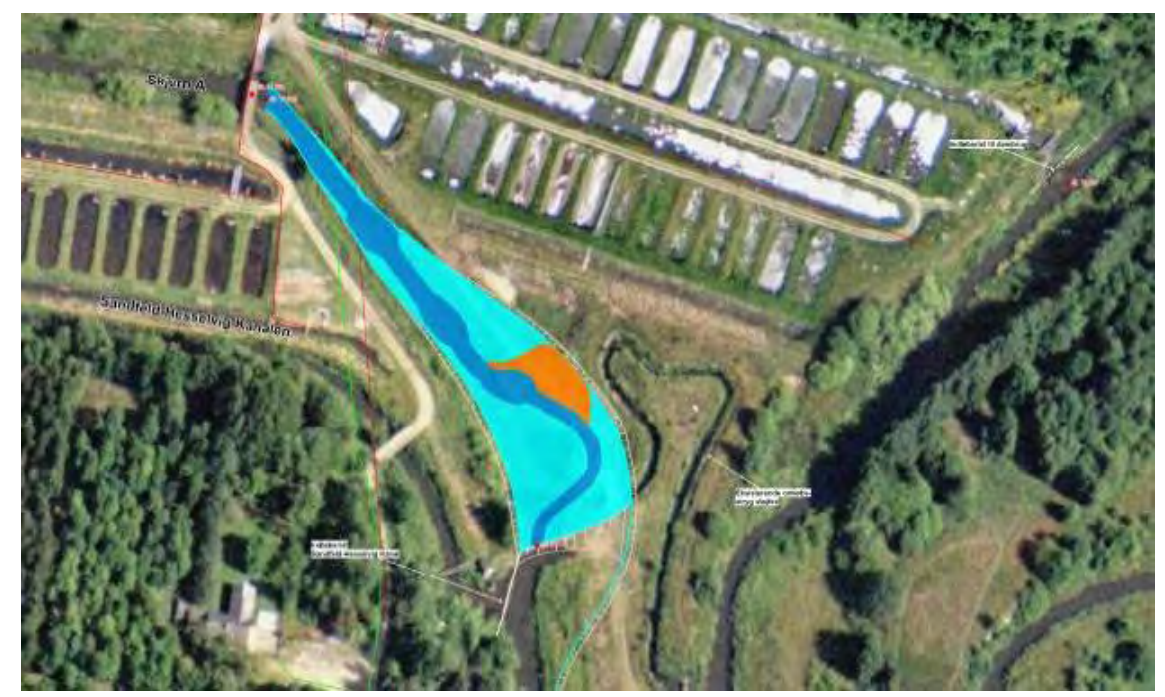

Fig. 34 Nyt stryg ved Sandfeld-Hesselvig Kanal.

Foto: Herning Kommune. 
Opnåede resultater

- Flere laks, lampretter, odder, kølleguldsmede og isfugle vil være resultatet af en fælles indsats.

- En stor spærring ved Kideris dambrug planlægges nedlagt.

- Sommerens faunaundersøgelser viser fremgang for den sjældne guldsmed grøn kølleguldsmed.

- Der er udarbejdet faktaark for isfugl og grøn kølleguldsmed på kommunens hjemmeside.

- Fangstrapporterne for laks viser fortsat fremgang i 2009 nedenfor de nævnte spærringer.

- Etablering af Arnborg Kirkesti langs et tilløb til Skjern $\AA$.

- Lokalt isfugleprojekt i Sønder Felding er under planlægning.

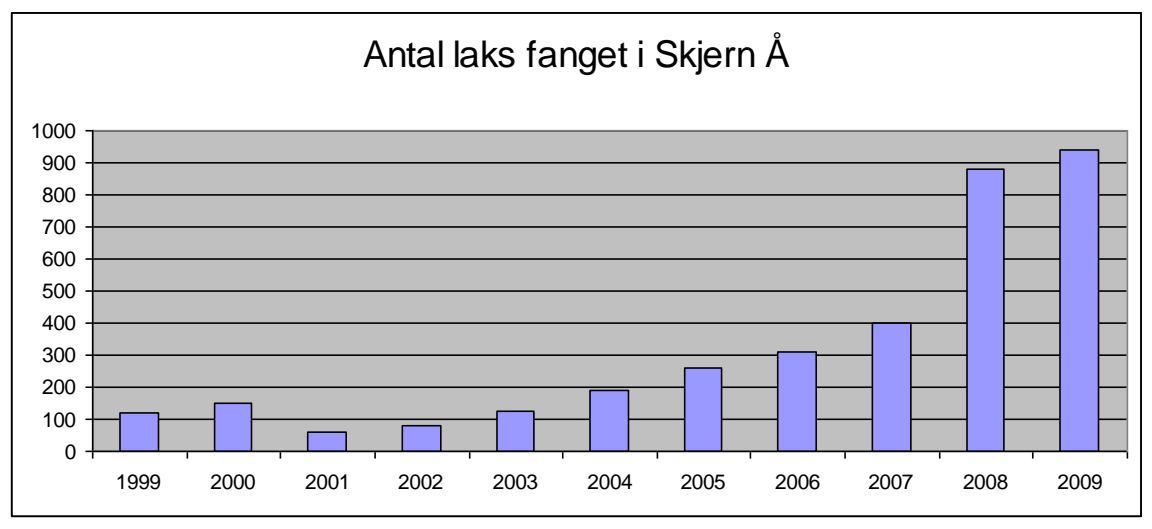

35 Antal laks fanget $i$ Skjern A.

Kilde: Skjern Å sammenslutningen

\section{Videre opfølgning}

Længere ude i fremtiden vil lystfiskeri kunne give turistindtægter til området.

Rekreative udfoldelsesmuligheder for både lokale og turister.

Oplevelsesturisme i forbindelse med den kommende Nationalpark Skjern $\AA$

\section{Erfaringer}

For at forbedre forholdene for laks og de andre dyr og planter i og ved Skjern $\AA$, er det vigtigt, at både politikere, lodsejere og brugere mødes for at forstå hinanden, naturen og laksen. Den stiller også store krav.

Det er vigtigt at sikre at værdifulde søer og mose- og engområder ikke lider skade ved projektet.

[http://www.skjernaa.info/] 


\subsection{Projekt 3. Klimainnsats i Herning kommune}

Klimaændringerne, er en stor trussel i forhold til den biologiske mangfoldighed. Mange arter, især de højt specialiserede kan ikke nå at tilpasse sig ændringerne og har ikke mulighed for at flytte sig hurtigt nok. Med en stigning på over $2^{\circ}$ siger scenariet at mere end $30 \%$ at de jordlevende arter vil uddø.

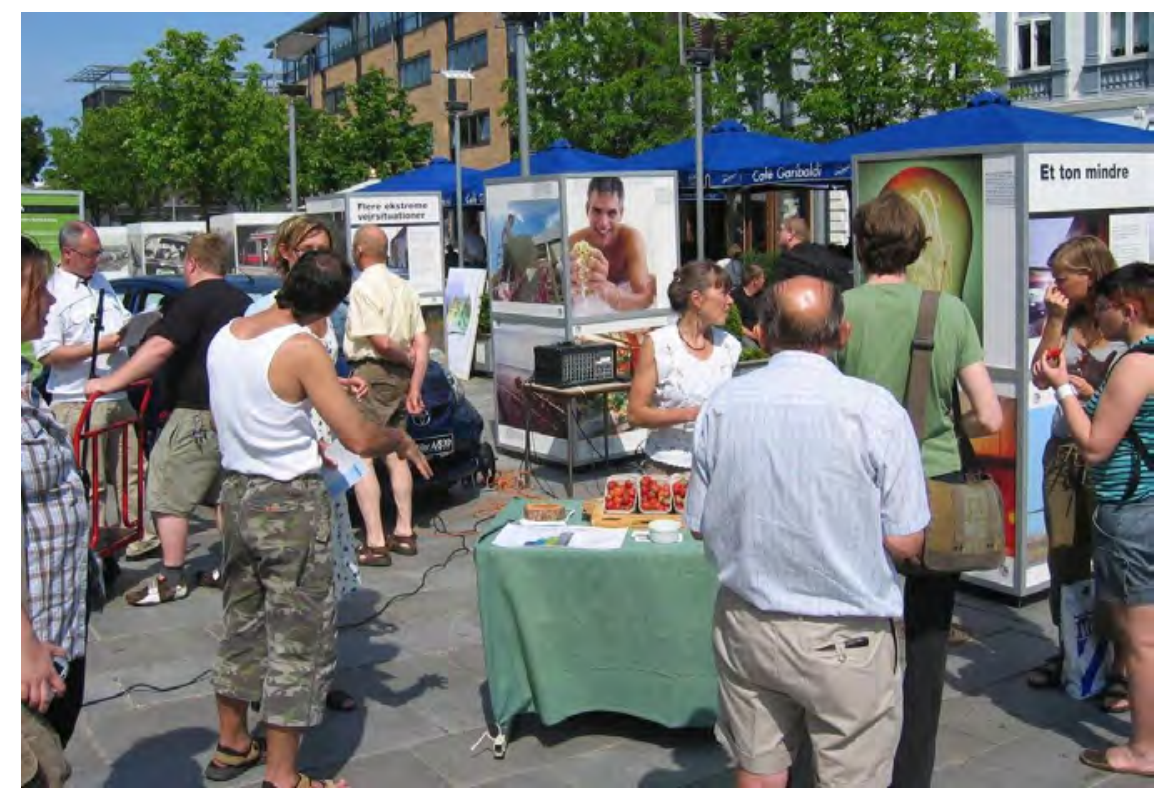

Fig. 36 Klimauge på torvet $i$ Herning By.

I arbejdet for at nå 2010 målene mener vi det er vigtigt ikke kun at fokusere på lokale naturprojekter, men også at forsøge at være med til at ændre på mere overordnede faktorer, der er med til at forårsage tilbagegang i den biologiske mangfoldighed.

Derfor er vi påbegyndt en klimaindsats der både retter sig mod borgerne og mod kommunens eget bidrag til CO2 udledningen. Klimaindsatsen sætter fokus på en række virkemidler. Nogle af disse er:

- Klimahandleplan med konkrete mål og tidsrammer (udarbejdet i 2008, vedtaget 2009, implementering fortsætter)

- Klimalandsby Studsgård (opstart 2008 og fortsætter )

- Borgerretted information og kampagner (2007 og fortsætter )

- Klimanetværk: Samarbejde med lokale aktører om konkrete klimaprojekter (2007 og fortsætter)

- Skovrejsning som klimaindsats (2007- ?) 


\section{Målscetning}

Overordnet målsætninger:

På klimaområdet har vi en række målsætninger. Overordnet mål er at nedbringe udledningen af samtlige drivhusgasser med $35 \%$ inden 2030 samt at nedbringe $\mathrm{CO} 2$-udledningen med $25 \%$ i 2015.

Målsætninger og resultater er desuden nævnt under de enkelte projekter.

\section{Gennemførte tiltag}

Herning Kommune har siden 2007 arbejdet med klimaindsatsen fra flere forskellige vinkler:

Klimahandleplan med konkrete mål og tidsrammer (2009 og frem)

En ambitiøs klimaplan er vedtaget i foråret 2009.

Mål: Klimaplanen omfatter kommunens overordnede klimamål samt mål og handleplan for fire fokusområderne: Varme- og energiforsyning, transport, virksomheder og landbrug.

- Klimaplanen omfatter både kommune som geografisk område og kommunen som virksomhed.

I tilknytning til Klimaplanen er arbejdet med en klimatilpasningsplan påbegyndt.

Natur og biodiversitet er både direkte og indirekte knyttet til klimaplanen. Indirekte fordi den overordnede nedbringelse af drivhusgas er en forudsætning for at mindske klimaændringernes skader på natur og biodiversitet, og direkte gennem hele tiden at tænke naturfokus ind i klimaprojekter. Det være sig landbrugsprojekter, skovrejsning, muligheder for naturfremme igennem klimatilpasning mv.

Der er allerede opnået en række resultater som konsekvens af at Herning Kommune har vedtaget en klimaplan.. Bl.a. kan nævnes:

- Omlægning til $97 \%$ flis og træpiller i kommunens store kraftvarmeværk der forsyner ca. $60 \%$ af kommunen med varme.

- Kampagne for tilslutning til klimavenlig fjernvarme

- Opstart af biogasprojekt - Blue Planet (Herning Kommune har et stort biogas potentiale da det er en landbrugskommune)

- Opstarte af Cyklehandleplan

Der er ansat en klimakoordinator, som udelukkende arbejder med implementering af aktiviteterne i planen. Og der er iværksat aktiviteter inden for alle fire områder. Klimaplanen skal desuden revideres hvert fjerde år.

\section{Klimalandsby Studsgård (2008 og frem)}

Mål: Landsbyen Studsgård med 250 familier vil være klimalandsby. De har sat sig et mål om at skære landsbyens samlede CO2-udledning ned med 25 \% inden 2012. Studsgård er gået i gang med flere projekter: 
Energibesparlser og renovering $i$ boligerne samt - målet er at de der har oliefyr skifter til den klimavenlige fjernvarme og at alle reducer deres energiforbrug - Projektstart januar 09

„Kog for kloden “-klimamad på menueen. - målet er at familierne reducere deres kødforbrug og madspild køber årstidens lokale råvarer mv. Landsbyen arrangere fællesspisning med klimamad hver måned.

Affaldssortering - fokus på metalindsamling - Studsgård har fået en metalcontainer og lavet kampagne for at få familierne til at frasortere metal, der giver en god klimagevinst. Yderligere affaldssortering etableres på torvet i starten af 2010.

Genplant planeten er et skovrejsningsprojekt hvor Studsgård skole i samarbejde med en lokal lodsejer samt kommunen og skovdyrkerforeningen planter skov i lokalområdet. 5 ha. Lægges om til blandet løvskov hvilket giver en CO2- reduktion på ca 67 tons pr år (Svarede til ca. 8 studsgårdfamiliers årlige udledning).

Herning Kommunes Grønne Guide er ressource person og hjælper Studsgård borgerforening med at planlægge og gennemføre projekter. Der er planlagt projekter vedr. løbende måling af landsbyens CO2-udledning og opførsel af en fælles vindmølle

\section{Borgerfokuserede informationer og kampagner (2007 og frem)}

Herning kommune har i 2007-2009 afholdt følgende kampagner: Energibesparelser og konvertering til CO2-venlig varme i 8 landsbyer. Stand med klimainformation ved 10 arrangementer. Klimauge 2008 og 09 med mange klima-arrangementer. Deltaget i 8 klimaevents. Lavet hjemmeside, flyere og foldere med klimaråd og vejledning.

Det er en del af Herning kommunes miljø- og klimamål at der løbende skal iværksættes borgerrettet information og kampagner

\section{Klimanetvark: Samarbejde med lokale aktører om konkrete projekter (2007 og frem)}

Klimanetværk Herning blev etableret i september 2007, hvor Herning Kommune inviterede lokale virksomheder, foreninger m.fl. til at mødes med det formål, at arbejde for en lokal klimaindsats. I dag omfatter netværket 42 medlemmer, lige fra brancheorganisationer, byggeri, energi, landbruget, borgerforeninger, til videns- og uddannelsesinstitutioner m.fl.

I 2008 og 2009 var klimanetværk Herning med til at iværksætte en række initiativer:

- Climate Camp i samarbejde med Herning Kommune

- Temamøde om transport

- Miniseminar med politiker om klimaplanen

- Klimalandsby Studsgaard

- Vi cykler til arbejde

- Klimauge 2008 og 2009 
- Klima som tema til Boligdrømme for Alle

- Hydraulisk solcellepanel

En af Klimanetværkts vigtigste aktivitet i 2008 har været samarbejde med Herning Kommune om udarbejdelse af kommunens klimaplan. Herunder afholdelse af Climate Camp, hvor mere end 100 mennesker med relation til fagområderne: Varme, energi og byggeri, landbrug, transport og virksomheder, deltog for at komme med input til løsningsforslag og dialog om nedbringelse af $\mathrm{CO} 2$ og drivhusgasudledningen inden for de forskellige sektorer. De indkomne forslag blev efterfølgende indarbejdet i kommunens klimaplan.

\section{Skovrejsning som klimaindsats (2007 og frem)}

Mål: Skovrejsning er en indsats hvor klimamål og mål i kommunens naturpolitik falder sammen. Målet om skovrejsning er at kommunen skal være dækket af 19,2 \% skov i 2025. Det nationale mål er at $25 \%$ skal være dækket af skov i 2090. Skovrejsning bliver desuden brugt som en del af kommunens kliamakampagne, information og undervisning i projektet Genplant planeten, i samarbejde med lokale aktører

I 2009 er der gennemført 3 Genplant planeten projekter, hvor skoler er involveret $i$ at plante skov og samtidig få klima- og natuundervisning.

Naturpolitikken sikrer at der løbende sker den planlagte skovrejsning i Herning Kommune

I forhold til borgere og virksomheder er det vigtigt at kende målgruppen, at skabe ejerskab, medansvar og engagement og rammer for at projekterne kan udviklet. En god ressourceperson er ofte mindst lige så vigitg som økonomiske ressourcer.

I forhold til det interne arbejde i kommunen er ledelsesmæssig og tværfaglig opbakning, organisering og ansvarsfordeling, helt nødvendigt. Desuden er det nødvendigt med politisk ejerskab og opbakning.

Deltagelse i Nordisk Netværk for biologisk mangfoldighed har været med til at højne den politiske interesse for arbejdet og givet medarbejderne inspiration, engagement og ny viden.

Læs mere om Herning Kommunes klimaindsats på [www.herning.dk/ klima] 



\section{Holstebro kommune}

Holstebro Kommune har det hele. Det åbne land med de mange landsbyer mellem hav og fjord, og Holstebro by midt i det hele. Befolkningen på landet og i landsbyerne værdsætter, at der er højt til himlen i den smukke natur og sætter pris på de overskuelige lokalsamfund, hvor man kommer hinanden ved.

Ca. 17.000 mennesker bor i landdistrikter og landsbyer i Holstebro Kommune. I byerne Holstebro, Ulfborg og Vinderup er der tilsammen ca. 39.000 indbyggere.

Kommunen der strækker sig fra Vesterhavet mod vest til Limfjorden mod nord dækker ca. 80.000 ha. Meget er dyrkede landbrugsarealer, og de mange ådale, plantager, heder, kyster, fjorde og søer skaber en kommune med en varieret og spændende natur. Her er plads til et mangfoldigt dyre og planteliv, og vi mennesker kan nyde friluftslivets glæder.

\subsection{Projekt 1. Oprensning eller nygravning af 25 vandhuller}

- Vandhuller med en bestand af sjældne padder.

Holstebro Kommune er en typisk dansk kommune, der er præget af intensiv landbrugsdrift. Gennem århundrede har man udvidet landbrugsarealerne, drænet moser og enge, sløjfet vandhuller og mergelgrave, rørlagt eller udrettet vandløb. Resultatet er, at mange af vandfladerne langsomt er forsvundet fra landskabet.

Småsøer og vandhuller bliver langsomt fyldt op med organisk materiale, og udvikler sig til moser. Tilgroning og opfyldning er en naturlig proces, men for padderne, dvs. frøer, tudser og salamandere, er tilgroningen en trussel, da deres ynglesteder hermed forsvinder. Mange af søerne er dannet som dødishuller ved isens tilbagetrækning. Andre er dannet ved gravning efter mergel m.m.

Målet med projektet var at forbedre forholdene for padderne, hvoraf flere fremgår af habitatdirektivets bilag 4; stor vandsalamander Triturus cristatus, spidssnudet frø Rana arvalis og løgfrø Pelobates fuscus). Derfor planlagde Holstebro Kommune inden 2010 at iværksætte oprensning eller nygravning af 25 småsøer/vandhuller - alle med en bestand af de ovennævinte arter, eller med potentiale til at få en fast bestand ved spredning fra nærliggende vandhuller. 
De eksisterende vandhuller, samt nygravede, ligger delvis på arealer der er ejet af Holstebro kommune, og delvist på private ejede arealer. Fælles for alle er, at de ligger inden for områder med en kendt bestand af sjældne padder.

Projektet begyndte i 2007, efter kommunalreformen, hvor Holstebro Kommune overtog en række naturopgaver fra det tidligere Ringkjøbing Amt.

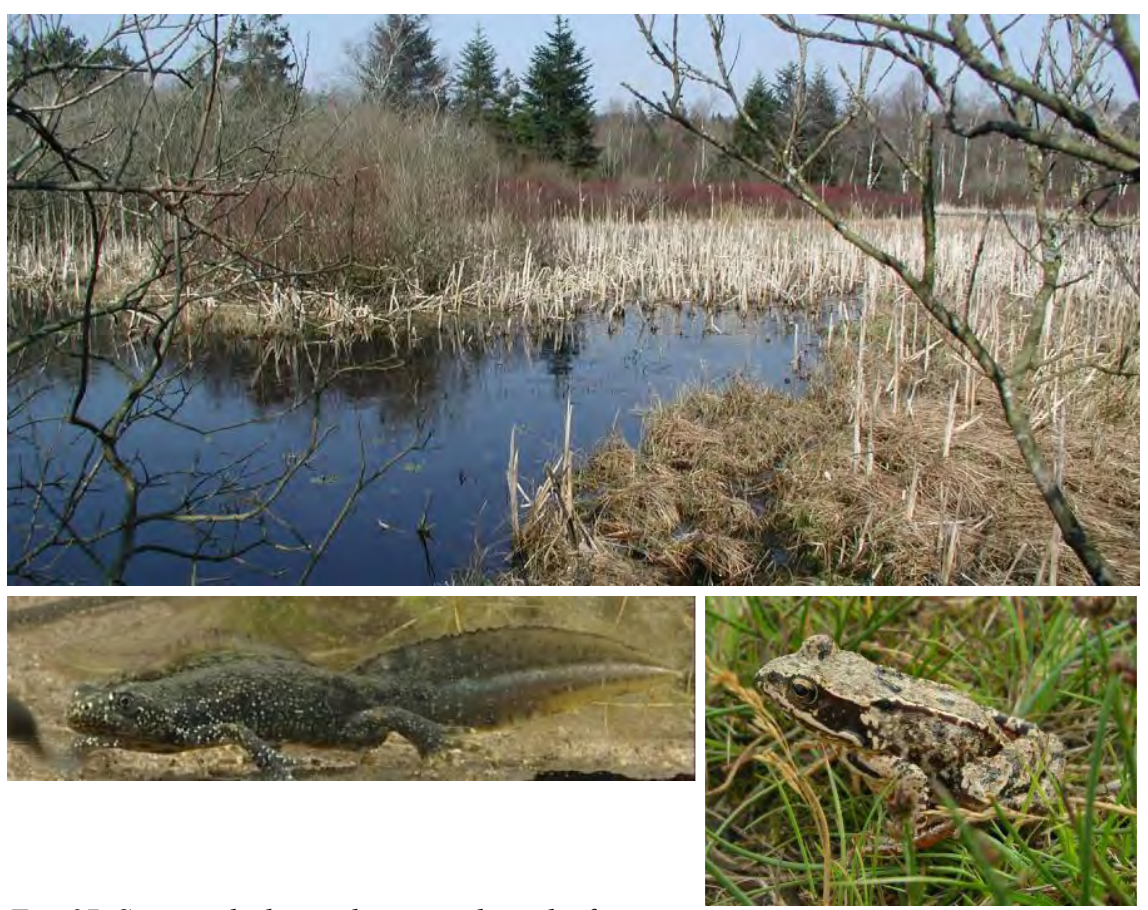

Fig. 37. Stor vandsalamander og spidssnudet frø.

Foto: Holstebro Kommune.

\section{Projektets mål i forhold til biologisk mangfoldighed}

- Ved oprensning af tilgroede vandhuller sikres ynglesteder for sjældne padder.

- Ved nygravning af vandhuller i kerneområderne for sjældne padder sikres mere stabile bestande, da bestande af padder kan sprede sig mellem vandhuller der ligger i samme område.

- Ved nygravning af vandhuller etableres spredningskorridorer mellem kendte bestande af sjældne padder.

- Ved formidling er det kommunens mål at udbrede kendskabet til problematikken om tab af biodiversitet, samt ved konkrete eksempler at vise hvordan man aktivt kan arbejde for stop i tab af biodiversiteten.

\section{Gennemførte tiltag}

- I perioden fra 2007-2009 har Holstebro Kommune gennemført oprensning af i alt 36 eksisterende søer og vandhuller i størrelsen ca. $100 \mathrm{~m}^{2}-1000 \mathrm{~m}^{2}$.

Oprensning er gennemført ved, at en gravemaskine har fjernet dynd og mudder fra bunden af vandhullet. Træer og buske der står tæt på vandkanten fjernes eller tyndes ud, og i visse tilfælde er det nødvendigt at 
fjerne gammelt affald og grene fra vandhullet. Eventuelle tagrør i vandkanten fjernes helt eller delvis, og det opgravede materiale bredes ud, så brinkerne får at fladt anlæg, hvor padder nemt kan komme op og ned. Oprensningen medfører, at vandet bliver mere iltrigt, og der bliver færre alger, andemad og andre flydeplanter. Der tilføres vandhullet mere lys og varme, som er vigtigt for livet $i$ vandhullet.

- I samme periode har Holstebro Kommune etableret 52 nye vandhuller i kerneområderne for sjældne padder, eller imellem kendte bestande, for at skabe spredningskorridorer mellem bestandene.

- Kommunen har i et af kerneområderne lavet aftale med en lokal skole, der som en del af undervisningen skal overvåge en række af de nye vandhuller, for at følge udviklingen af vandhullernes paddebestande. Overvågningen er helt uvidenskabeligt anlagt, men har til formål at skab forståelse for vigtigheden af at vi aktivt gør en indsats for at bevare biodiversiteten i vores natur.

- Projekt 1 har særligt haft fokus på de små vandhuller, og ikke de store søer, da her ofte findes en bestand af rovfisk, som er en direkte trussel for paddebestandene.

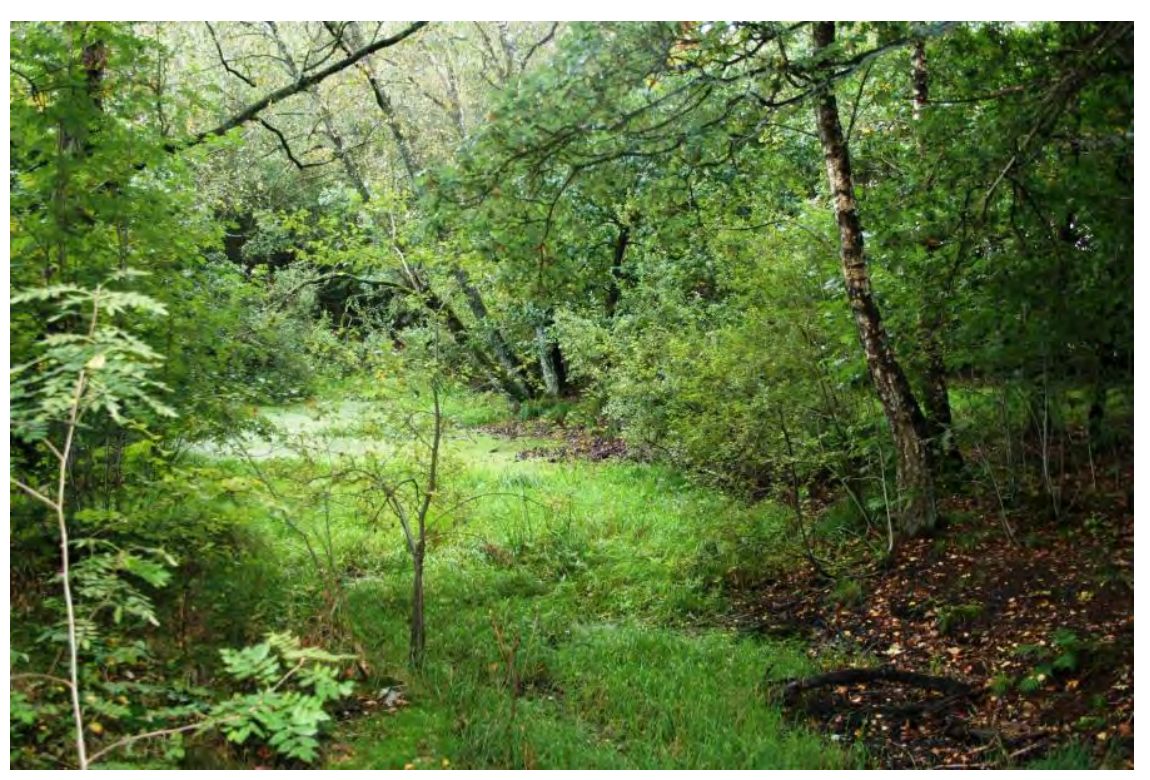



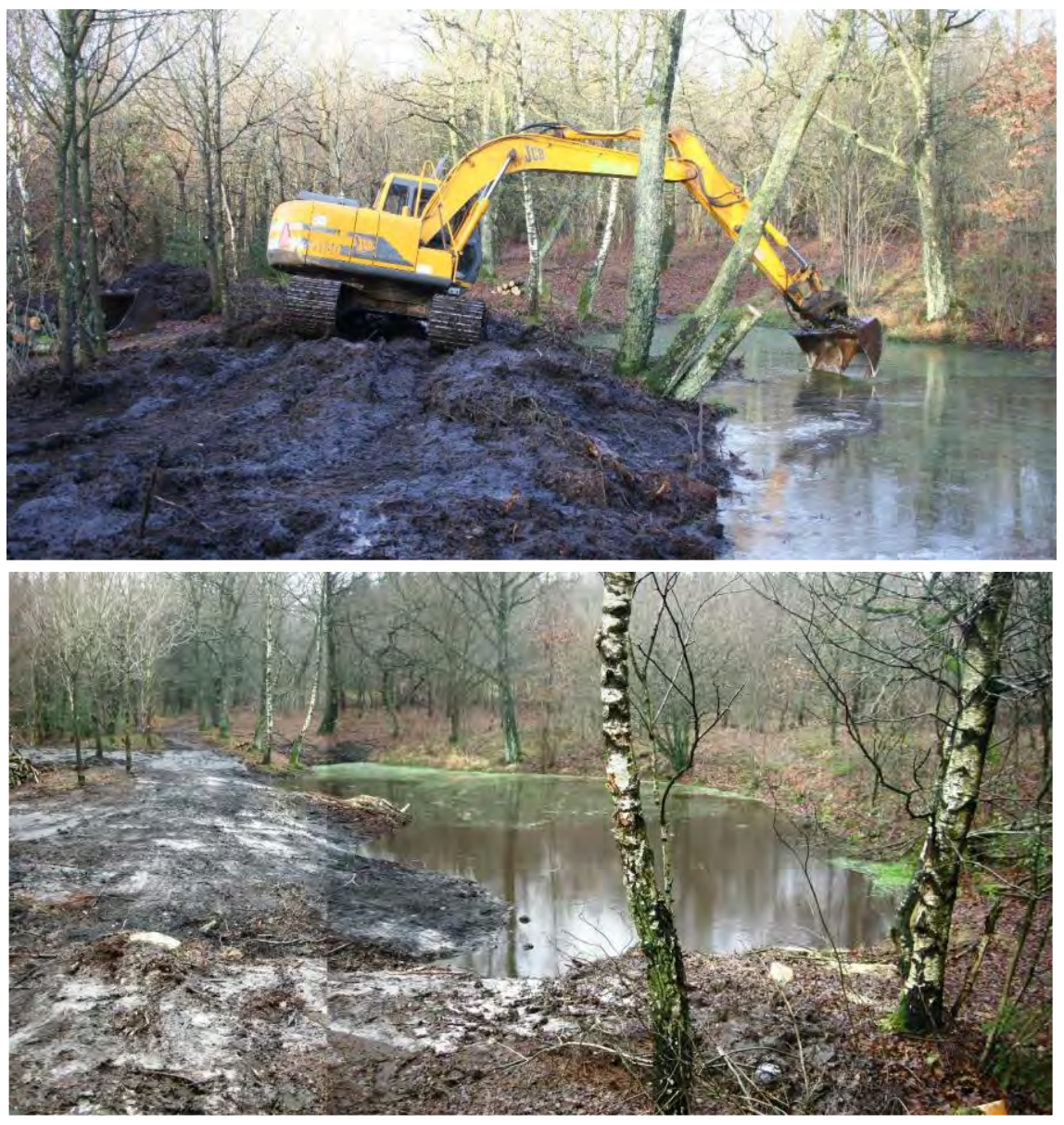

Fig. 38. Vandhul i Skovlund før, under og efter oprensning (december 2007). Foto: Holstebro Kommune.
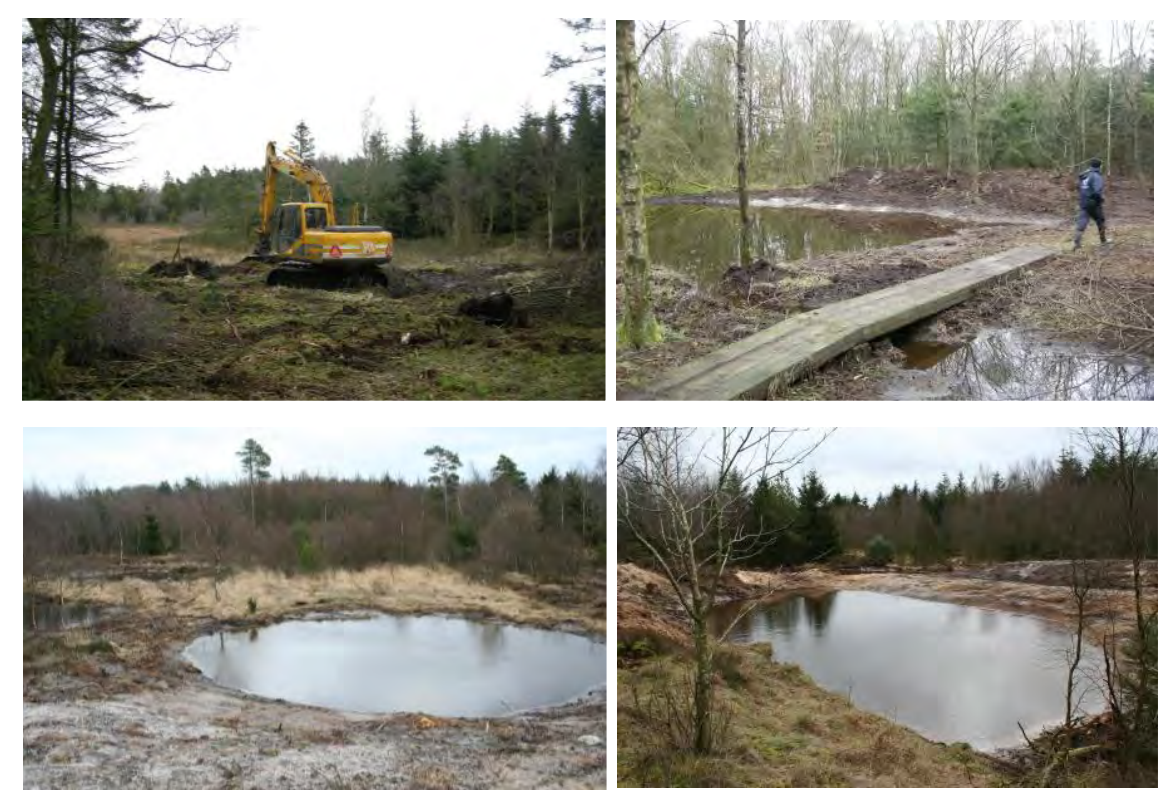

Fig. 39. Nyetablering af vandhuller i Ryde Plantage (2008 - 2009).

Foto: Holstebro Kommune. 


\section{Opnåede resultater}

Målet for projekt 1 var oprensning/nyetablering af 25 vandhuller/småsøer, med en bestand, eller potentiale for en bestand, af sjældne padder. Resultatet blev ikke mindre end 88 .

Projekt 1 forventes at bidrage væsentligt til stop for tab af biodiversitet blandt en dyregruppe (padderne), der ikke tidligere har været særlig stor fokus på i forbindelse med kommunens naturplejeprojekter.

I flere af de kendte paddelokaliteter i Holstebro Kommune er der etableret væsentlig forbedrede vilkår for stor og lille vandsalamander, spidssnudet frø, løgfrø, strandtudse og andre mere almindelige padder. Der er skabt en tæthed af vandhuller i områderne, samt forbedrede spredningskorridorer, der sikrer stabilitet i bestandene, samt bedre spredning til og fra de enkelte bestande.

De gennemførte projekter har lokalt vakt stor interesse, hvilket har resulteret i flere henvendelser fra private lodsejere, der gerne ville indgå i projektet, dels med ønske om oprensning af eksisterende vandhuller, men også private, der gerne ville lægge jord til gravning af nye vandhuller.

I løbet af perioden er der foretaget besigtigelser af projektområderne, og der er mange steder konstateret succesrig klækning. Det er dog ikke alle nye vandhuller, der er taget $\mathrm{i}$ brug endnu, men det er ikke unormalt, at et nygravet vandhul skal stabilisere sig, inden padderne vil klække i dem.
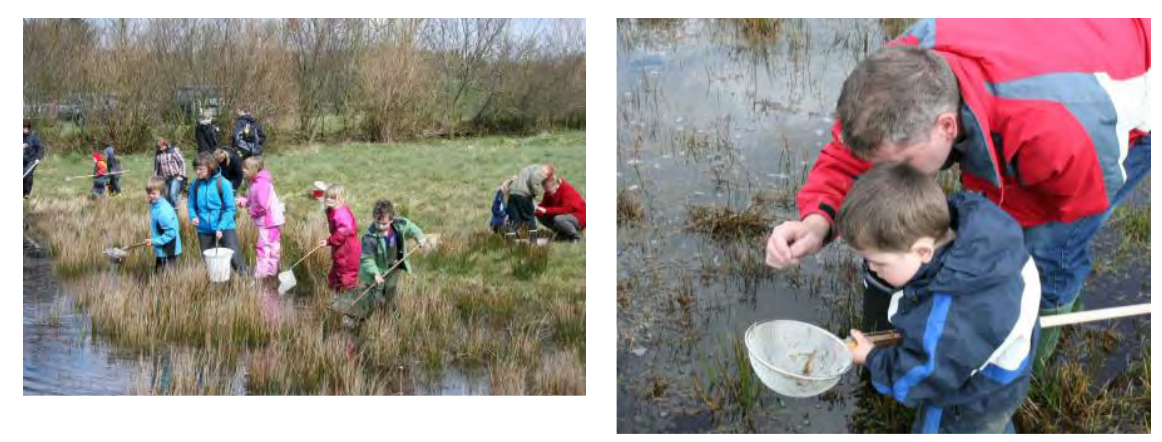

Fig. 40. Naturvejledning ved et af de nye vandhuller.

Foto: Holstebro Kommune.

\section{Videre opfølgning}

Målene for 2010 projektet er for længst opfyldt, og Holstebro Kommune ser på de opnåede resultater med stor tilfredshed. Private lodsejere henvender sig fortsat med ønske om hjælp fra Holstebro kommune til nye vandhulsprojekter, hvilket kommunen fortsat er indstillet på at imødekomme. Det er dog en betingelse for tilskud, at projektet er til gavn for sjældne padder. Etablering af vandhuller der primært er til gavn for jagtinteresser og lignende støttes ikke.

På nuværende tidspunkt har Holstebro Kommune aftale om tilskud til oprensning/etablering af 10 vandhuller, ud over de 88 projekter der allerede er gennemført. Projekterne ventes gennemført i vinteren 2009 - 2010. 
Fra 2010 og frem er det planen, at Holstebro Kommune vil starte et overvågningsprogram som opfølgning på CountDown 2010 projektet. Overvågningen skal afdække effekten af paddeprojektet

Ryde skole vil, som en del af undervisningen i natur og teknik, følge udviklingen i nygravede vandhuller i Ryde Plantage. Formålet er ikke egentlig overvågning, men at gøre børnene interesserede i naturundervisning ved at flytte klasselokalet ud i naturen.

\section{Erfaringer}

For at få succes med gennemførelse af naturplejeprojekter, som projekt 1, er det vigtigt at have kendskab til hvor vi har en bestand af de arter vi ønsker at tilgodese. Med denne viden er det muligt at udføre målrettede projekter, der giver mest natur for pengene.

Inden start på projektet satte Holstebro Kommune sig et ambitiøst mål på oprensning/etablering af 25 småsøer/vandhuller, men endte på foreløbigt 88 . Det har givet os en tro på, at det er vigtigt at komme i gang med konkrete projekter. Alt for ofte ender naturforvaltning med overordnede planer og forkromede projekter der tager lang tid. Selv små projekter kan udvikle sig når de er startet op.

Med Holstebro Kommunes projekter var det et ønske, at der skulle ske noget i naturen til fordel for bevarelse af biodiversiteten. Noget der var synligt, og kan inspirere andre til at sætte projekter i gang. Udarbejdelse af overordnet planlægning kan ikke undværes, men mister sin værdi hvis vi mister arter og natur inden de store planer kommer til udførelse. På baggrund i vores projekter, er vi blevet bestyrket $\mathrm{i}$ troen på, at selv små projekter har stor værdi.

\subsection{Prosjekt 2. Iværksættelse af afgræsning}

Etablering af afgræsning på højt målsatte enge og moser

Holstebro Kommune er kendetegnet ved gennemløb af mange store og små vandløb. I ådalene, langs vandløbene, ligger lave vådområder (enge), der traditionelt har været udnyttet landbrugsmæssigt til afgræsning og/eller høslæt til dyrefoder.

På grund af ændring i landbrugsdriften har disse lavbundsområder ikke længere den samme betydning for landbruget, hvorfor de ikke længere indgår i moderne landbrugsdrift. Disse forladte engområder gror derfor langsomt til i piletræer m.m. Processen er naturlig, men til stor skade for den typiske og meget varierede flora, der er knyttet til de afgræssede engarealer. Blandt de sjældne arter kan nævnes orkideer, engblommer, hjertegræs m.fl. Engene er kendetegnet ved stor diversitet, der ud over flora også omfatter et rigt insekt- og fugleliv. Som de ferske enge er strandenge og overdrev ligeledes udsat for tilgroning. 
Naturområder der er ejet af staten, fredet ved kendelse og/eller ligger inden for et internationalt naturbeskyttelsesområde (natura-2000 område) er der i disse år meget fokus på. Her er naturforvaltningen sikret ved lovgivning, samt kommende vand- og naturplaner. I de øvrige naturområder forholder det sig anderledes. Områderne er nok beskyttet af naturbeskyttelsesloven, men der forhindrer ikke tab af biodiversitet. Hverken lodsejer, stat eller kommune har lovmæssig pligt til at sikre overvågning eller naturpleje $\mathrm{i}$ disse områder. Lokalt kan disse naturområder have meget stor værdi. Selv små bestande af sjældne planter har betydning for overlevelse og spredning. Det er disse lokaliteter Holstebro Kommunes projekt nummer 2 er rettet mod. Lokaliteter der risikerer at forsvinde, fordi mere og mere fokus rettes mod de store naturområder der er omfattet af internationale beskyttelsesbestemmelser.

For at standse tabet af biodiversiteten ved tilgroning var målet for projekt 2, at Holstebro kommune igangsætter afgræsningsprojekter med får, heste eller kreaturer på mindst $50 \%$ af de højt målsatte enge og overdrev, der ikke allerede var afgræsset eller plejet på anden måde. For de resterende $50 \%$ forpligtede kommunen sig til at kontakte lodsejerne for at diskutere muligheden for afgræsning eller høslæt.

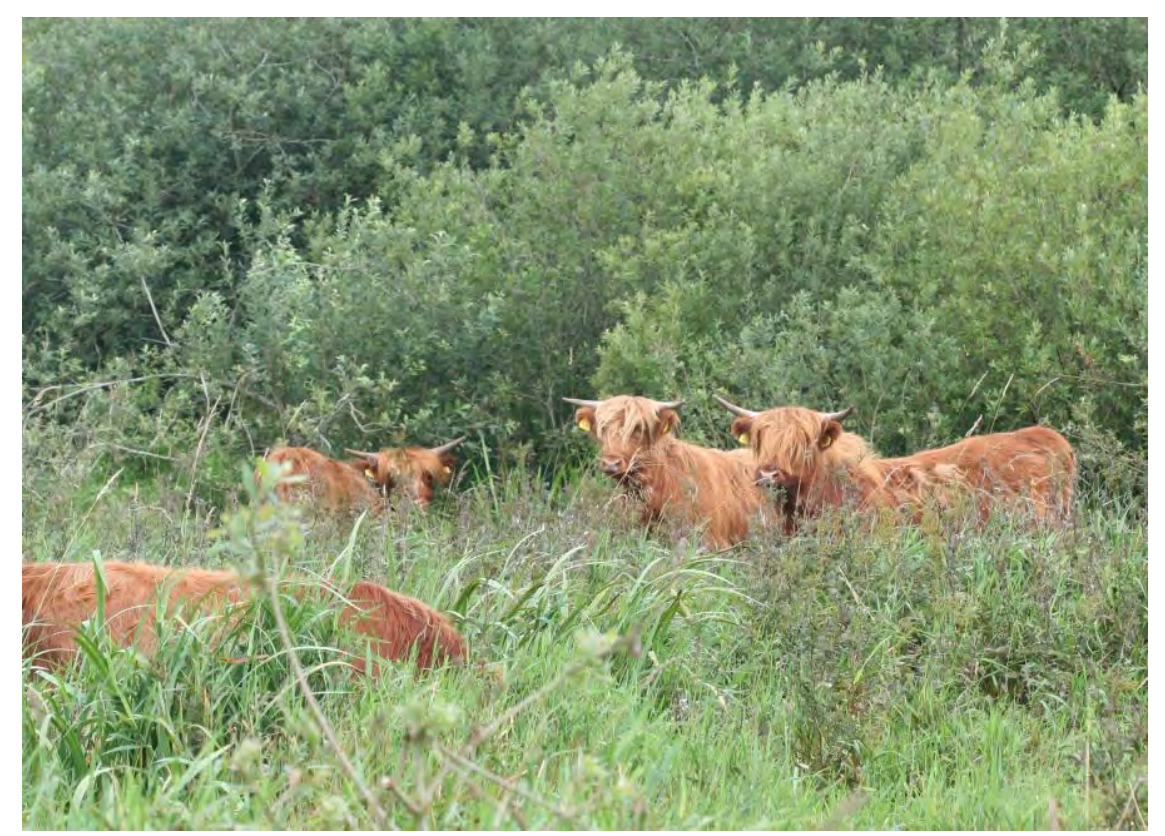

Fig. 41. Kreaturer på arbejde for biodiversiteten.

Foto: Holstebro Kommune.

\section{Projektets mål i forhold til biologisk mangfoldighed}

- 43 af kommunens vigtigste og højt målsatte naturområder overvåges.

- Overvågningen omfatter botanisk diversitet, plejebehov samt eventuelle ulovlige forhold.

- På mindst $50 \%$ af de områder, der vurderes at have behov for pleje, iværksættes den nødvendige naturpleje. Plejen vil i de fleste tilfælde 
være hegning og etablering af afgræsning med får, heste eller kreaturer.

- På de resterende $50 \%$ af arealerne med plejebehov har kommunen haft kontakt med lodsejeren for at drøfte mulighederne for naturpleje.

- Ulovlige forhold bringes i orden
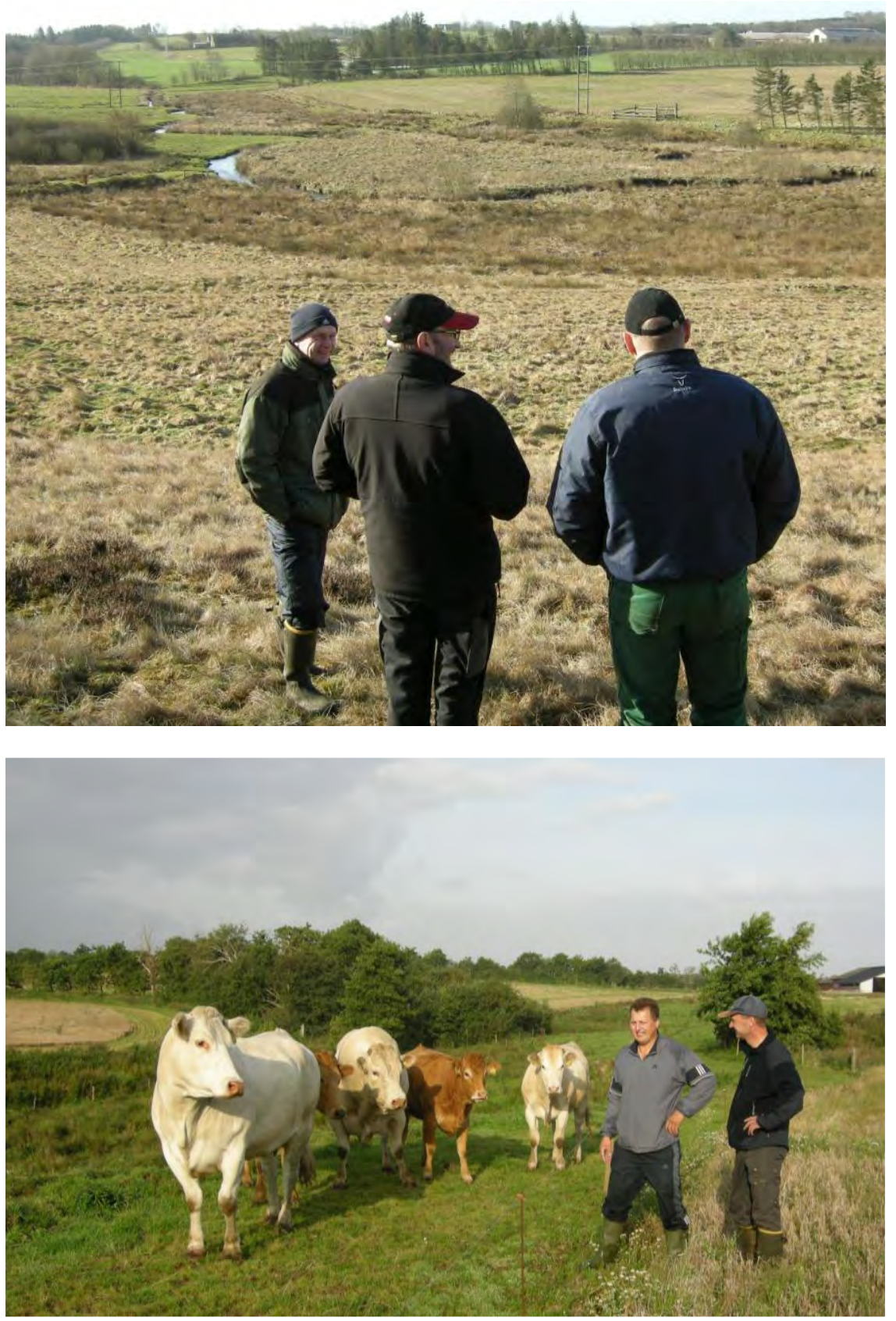

Fig. 42 Kommunens medarbejder indgår aftaler om naturpleje med lodsejere og dyreholdere. Foto: Holstebro Kommune. 


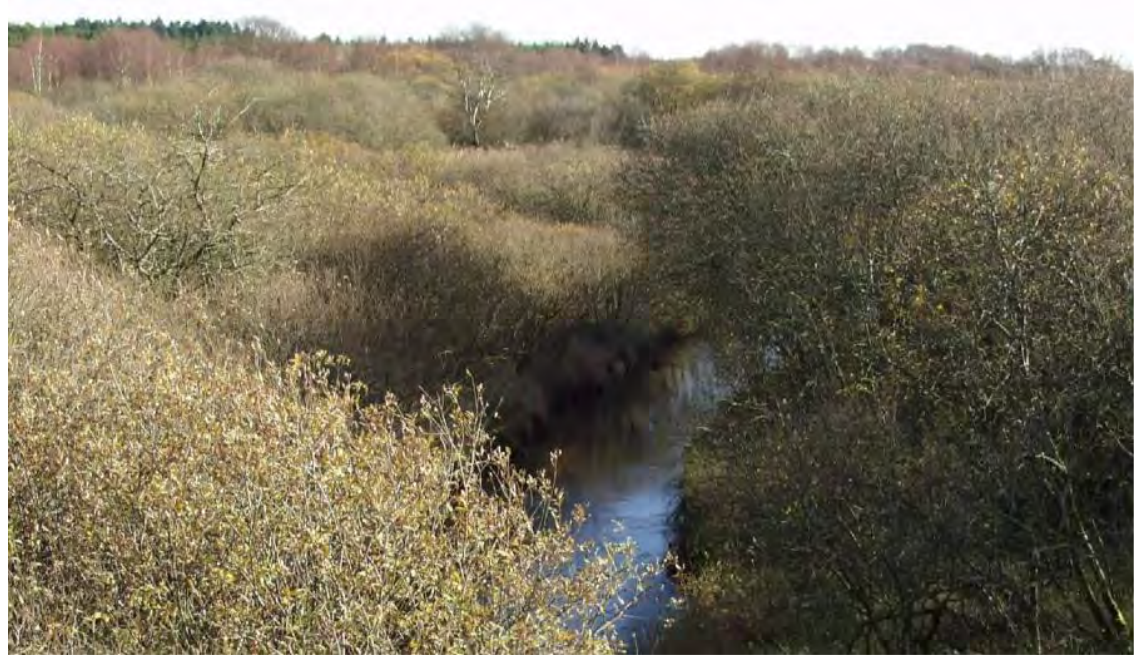

Fig. 43 Pilekrattet har naturligvis vaerdi for småfugle og rådyr, men orkideerne har ikke en chance her (Råsted Lilleå).

Foto: Holstebro Kommune.

\section{Gennemførte tiltag.}

Oprindeligt var 43 lokaliteter udpeget til at indgå i projektet. Lokaliteterne var udvalgt på baggrund af det tidligere Ringkjøbing amts naturplan, hvor alle kommunens naturområder blev målsat som $\mathrm{A}, \mathrm{B}$ eller $\mathrm{C}$ natur, med $\mathrm{A}$ som de mest værdifulde. Undervejs blev 3 lokaliteter opgivet, og 6 nye fundet egnet til at indgå. 49 lokaliteter blev dermed omfattet af projektet.

Ud fra eksisterende viden blev de botanisk mest værdifulde A- og Blokaliteter, der ikke er statsejede eller Natura-2000 område, valgt ud. Alle lokaliteter blev gennemgået grundigt, med systematisk botanisk registrering og vurdering af naturtilstand. Den aktuelle plejetilstand blev noteret, og et akut eller langsigtet plejebehov blev vurderet.

Tab 1. Resultat af gennemgangen som viste status til naturområdene og behov for tiltak

\begin{tabular}{lllll}
\hline \multicolumn{2}{c}{ Gennemgået 49 vigtige, botaniske lokaliteter (3 udgået) } & \\
\hline \multicolumn{2}{c}{$\begin{array}{l}\text { Nuværende indsats OK } \\
23 \text { lokaliteter }\end{array}$} & $\begin{array}{c}\text { Behov for indsats } \\
\mathbf{2 3} \text { lokaliteter }\end{array}$ \\
\hline $\begin{array}{l}\text { Plejes i forvejen i henhold til } \\
\text { græsningsaftaler med }\end{array}$ & $\begin{array}{l}\text { Plejes gennem } \\
\text { kommunen }\end{array}$ & $\begin{array}{l}\text { Ulmindelig drift } \\
\text { forhold }\end{array}$ & $\begin{array}{l}\text { Plejebehov } \\
\text { akut }\end{array}$ & $\begin{array}{l}\text { Langsigtet } \\
\text { plejebehov }\end{array}$ \\
5 lokaliteter & 18 lokaliteter & 2 lokaliteter & 13 lokaliteter & 8 lokaliteter \\
\hline
\end{tabular}

Efter gennemgang af registreringen blev arbejdet planlagt, og lodsejere kontaktet for at diskutere naturområdernes fremtidige drift, og planlægge aktuelle naturplejeprojekter. Indsatsen resulterede i følgende: 
- 30 af lodsejerne er kontaktet i løbet af projektperioden.

- 42,5 ha ny/genoptaget afgræsning blev etableret. I de fleste tilfælde betalte kommunen opstilling af hegn, eller renovering af eksisterende gammelt hegn, samt hjalp med formidling af kontakt til dyreholdere der var villig til at afgræsse arealerne.

- 8 arealer under tilgroning blev slået/ryddet for at forbedre afgræsningsmulighederne, samt stoppe tilgroning

- På 4 lokaliteter er kreaturovergange etableret for at forbedre afgræsningsmulighederne.

- 2 ulovlige forhold er bragt til ophør.

- 6 nye lokaliteter, der opfyldte kriterierne for at indgå i gruppen af de mest værdifulde botaniske lokaliteter, blev opdaget.

- 3 lokaliteter blev opgivet, da tilgroningen var for fremskredet (her kom vi for sent)

- 1 lodsejer ønskede ikke at indgå i en plejeaftale.

Ud over de nævnte lokaliteter gennemfører Holstebro kommune mange andre naturplejeprojekter. Dels indenfor natura-2000 områder, dels indenfor de fredede områder, men også på andre lokaliteter, hvor botanik og biodiversitet ikke alene er målet, men hvor det er naturtypen, det landskabelige eller mere almindelige arter der ønskes bevaret ved naturpleje.
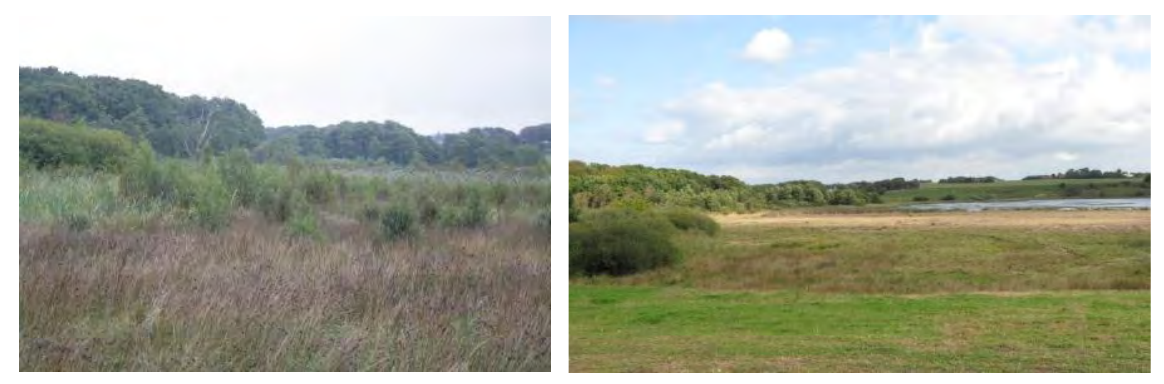

Fig. 44. Holmgård Sø før og efter plejeindsats.

Foto: Holstebro Kommune.

Opnåede resultater

Vigtige botaniske lokaliteter i Holstebro Kommune er nu sikret de bedst mulige forhold for bevarelse af biodiversiteten.

Med den gennemførte registrering har kommunen nu overblik over tilstanden på de vigtigste botaniske lokaliteter, der ellers er i risiko for at blive overset og glemt.

Kontakten til lodsejerne har i mange tilfælde øget lodsejernes interesse for naturen på deres ejendom. Enkelte lodsejere der selv har kreaturer, men overvejede at skære ned på antallet af dyr, har med kommunens opbakning og hjælp til hegning m.m. fået mod på at fortsætte.

Kontakten med lodsejere, og synligheden $\mathrm{i}$ kommunens projekter har fået andre til at kontakte os for nye mulige naturplejeprojekter. 


\section{Videre opfølgning}

Inspireret af dette Countdown 2010 projekt, har Holstebro Kommune startet et nyt projekt, der har til formål at sikre fremtidig overvågning og opfølgning på naturplejen på de (foreløbigt) 46 naturområder. Projektet er integreret med dette projekt, men har primært det formål at sikre arealerne for fremtiden.

Målet er mindst hver fjerde år at gennemgå hver lokalitet. Der udfyldes et registreringsskema, så udviklingen af biodiversiteten kan følges, og opfølgning af naturplejen sikres. Registreringsmetoden sikrer at de indsamlede data kan sammenlignes.

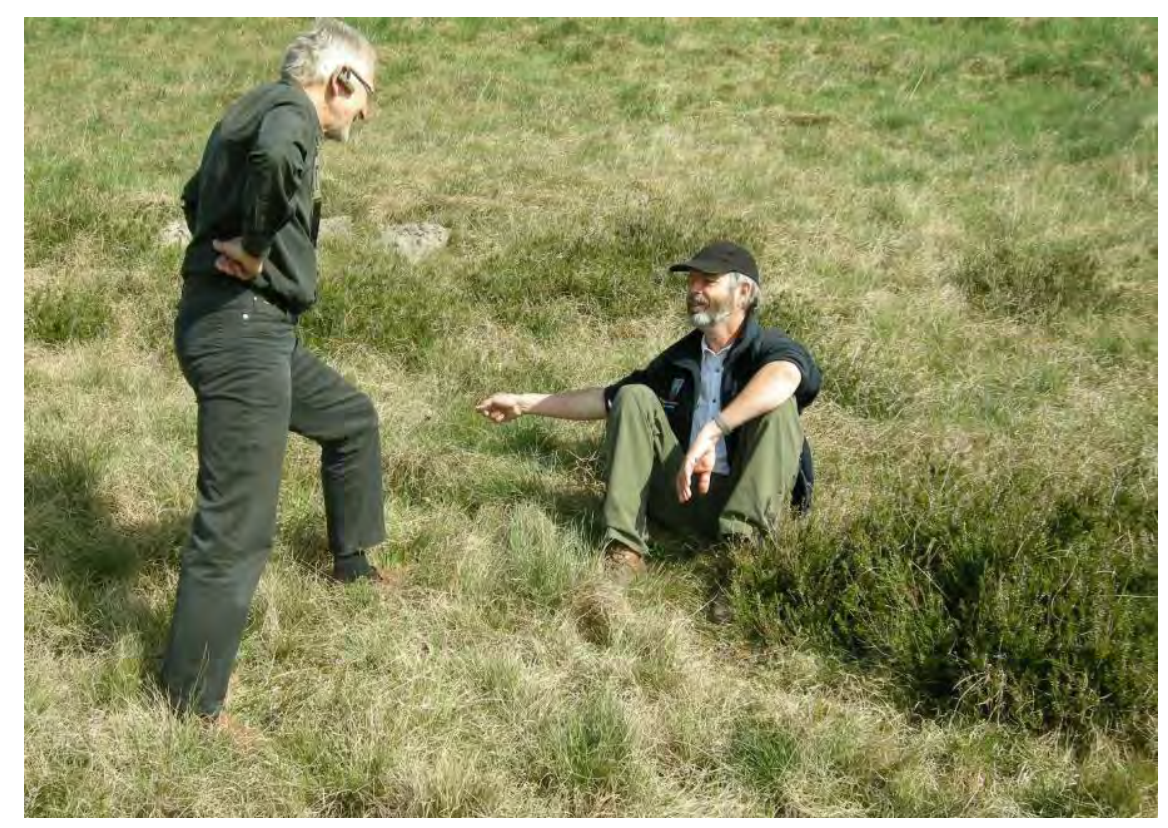

Fig. 45 Positiv lodsejer lytter interesseret til kommunens biolog.

Foto: Holstebro Kommune.

\section{Erfaringer}

Generelt er lodsejerne meget positive over vores henvendelser. Enkelte har særinteresser der gør at de ikke kan overtales til den pleje, vi mener vil være den rigtige, men vi har altid en god snak. Det skal bemærkes, at kommunen ikke har ret til pleje på arealer, men helt er afhængig af velvilje fra lodsejerne.

Der vigtigt, at vi kan tilbyde hjælp til naturplejen når vi mødes med lodsejeren. Det kræver opbakning fra kommunen, i form af frihed til at lave aftaler på stedet, samt økonomisk råderum.

For at få det optimale ud af indsatsen, er det nødvendigt med en god viden om områderne, men det er også vores erfaring, at man ikke skal tøve med at komme i gang med konkrete projekter ude i det virkelige liv. Der er en alt for stor risiko for, at dataindsamling og planlægning tager alt for lang tid. I mellemtiden mister vi biodiversitet. Derfor er erfaringen i Holstebro Kommune at vi skal i gang med projekter ude i det virkelige liv, og lave planlægningen sideløbende. Det er muligt, at mere viden og overordnet 
planlægning viser at vi bør prioritere vores indsats anderledes i fremtiden, men indtil da må vi bruge den viden vi har til at øge biodiversiteten i de områder vi kender.

\subsection{Prosjekt 3. Adgang til gydepladserne for laksen}

Ved 4 spærringer skabes fri adgang til gydepladserne for fisk i vandløbende

\section{Projektbeskrivelse}

Langs mange jyske vandløb er der gennem tiden etableret et opdræt af ørreder i jorddamme (ferskvandsdambrug). Ved etablering af dambrugene har man bygget stemmeværker i vandløbet, for at opdæmme vandet og lede det passivt ind til dammene. Disse spærringer har i de fleste tilfælde forhindret, eller forringet mulighederne for vandløbenes naturlige bestand af fisk, som laks, havørreder, lampretter m.fl., at trække op til de dele af vandløbet hvor de yngler.

Mange dambrug er med tiden opkøbt af myndighederne og nedlagt, og vandløbet efterfølgende genslynget, men der genstår at få forbedret passageforholdene ved en række dambrug.

Ved nedlæggelse af opstemninger og genslyngning af vandløb vil Holstebro kommune bidrage til forbedring af passageforholdene for den naturlige bestand af blandt andet laks, ørreder, lampretter i vandløbene, ved mindst 4 spærringer, så fiskene igen får fri adgang til gydepladserne.

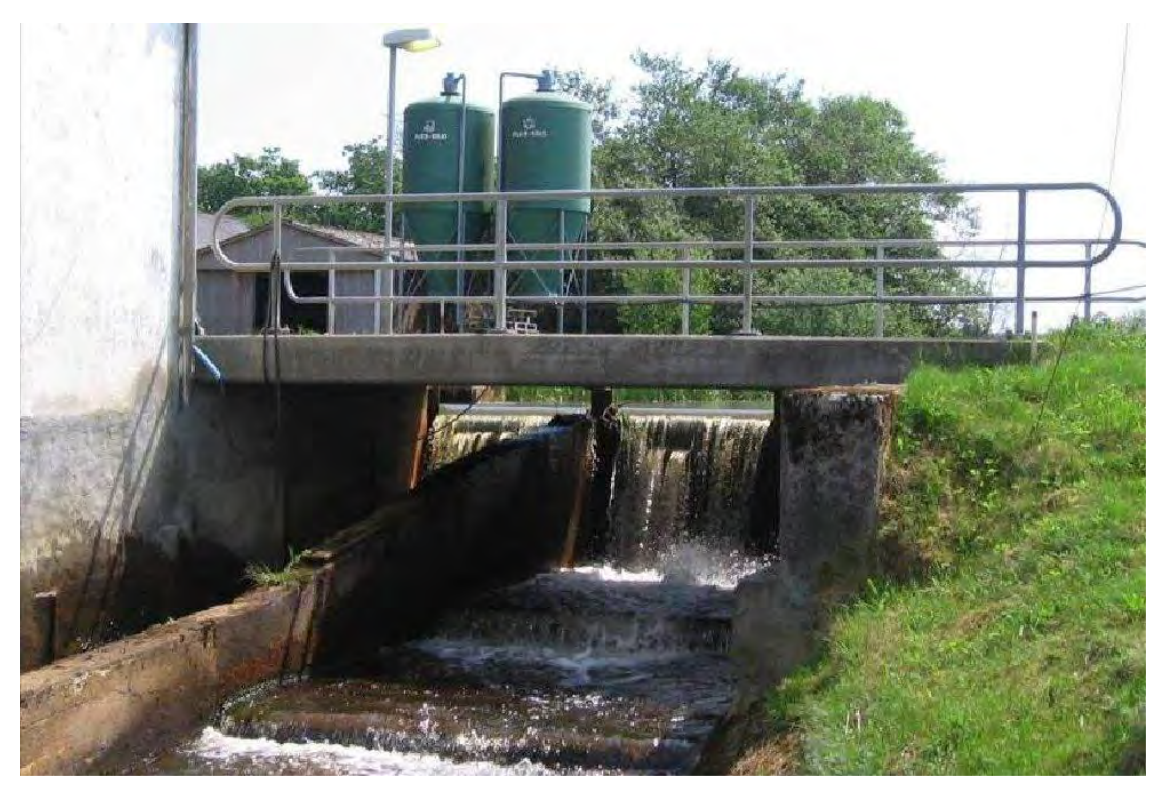

Fig. 46 Her kommer laks, havørreder og lampretter ikke forbi (Nymølle Dambrug 2006).

Foto: Holstebro Kommune. 


\section{Projektets mål i forhold til biologisk mangfoldighed}

Miljøministeriet udsendte i 2004 en national forvaltningsplan for den danske laks. Storå-laksen er i planen udpeget som en af landets 4 vigtigste laksebestande. Skov- og Naturstyrelsen har i samarbejde med Ringkjøbing Amt i første omgang valgt, at prioritere forbedringer for laksen i Råsted Lilleå, der har udløb til Storå ved Vemb.

Holstebro Kommune har på den baggrund udarbejdet egentlige projekter, der er blevet gennemført i 2007 og 2008. Dambrugsejerne indgår i projekterne ved at ombygge dambrugene til moderne modeldambrug med lille vandforbrug og god vandrensning.

Stemmeværker er blevet fjernet og over 2,3 km vandløb har fået sine slyngninger tilbage. Projekterne giver fri vandremulighed for fisk og vandløbets smådyr, ligesom der skabes ideelle gydemuligheder for bl.a. laks i de genslyngede strækninger hvor åen får god vandhastighed. De nye åslyngninger udligner et fald på over 5 meter i vandløbet.

Holstebro kommune forventer, at dambrugenes igangværende ombygning til en produktion baseret på grundvand eller indpumning af åvand vil give hurtige resultater i form af en hastigt voksende bestand af laks, havørred og stalling, men også have positive effekter for de sjældne flod- og havlampret, der er særligt beskyttet af EF-habitatdirektivet i Nissum Fjord.

\section{Gennemførte tiltag}

Nymølle dambrug - Det gamle dambrug er nedlagt, spærringen fjernet, og der er etableret et nyt såkladt „Model-dambrug“ der baserer sin produktion på grundvand. Opstrøms bro ved Gl. Råstedvej er $700 \mathrm{~m}$ genslynget å etableret november 2007 og april 2008, og nedstrøms bro ved Gl. Råstedvej er $260 \mathrm{~m}$ nyt åløb etableret øst for det nye dambrug.

Christiansminde dambrug - Det gamle dambrug er nedlagt, spærringen fjernet, og der er etableret et nyt „Model-dambrug“, der baserer sin produktion på grundvand. På en strækning over ca. $530 \mathrm{~m}$ er faldforholdene genoprettet, og fiskenes frie vandring genskabt.

Råsted Gl. Mølle dambrug - Det gamle dambrug er nedlagt og spærringen fjernet. På en strækning over ca. $600 \mathrm{~m}$ er åen genslynget, og fiskenes frie vandring genskabt.

Vester Hvoldal/Hvolby dambrug - Spærringen ved Vester Hvoldal/Hvolby dambrug er fjernet, og der etableres nyt omløbsstryg over en strækning på ca. $100 \mathrm{~m}$. Fiskenes frie vandring er genetableret.

Etablering af gydebanker - For at forbedre fiskenes mulighed for succesfuld gydning er der etableret gydebanker i alle de nyetablerede stræk af Råsted Lilleå. Over $1.000 \mathrm{~m}^{3}$ gydegrus er fordelt ved de 4 projekter. 


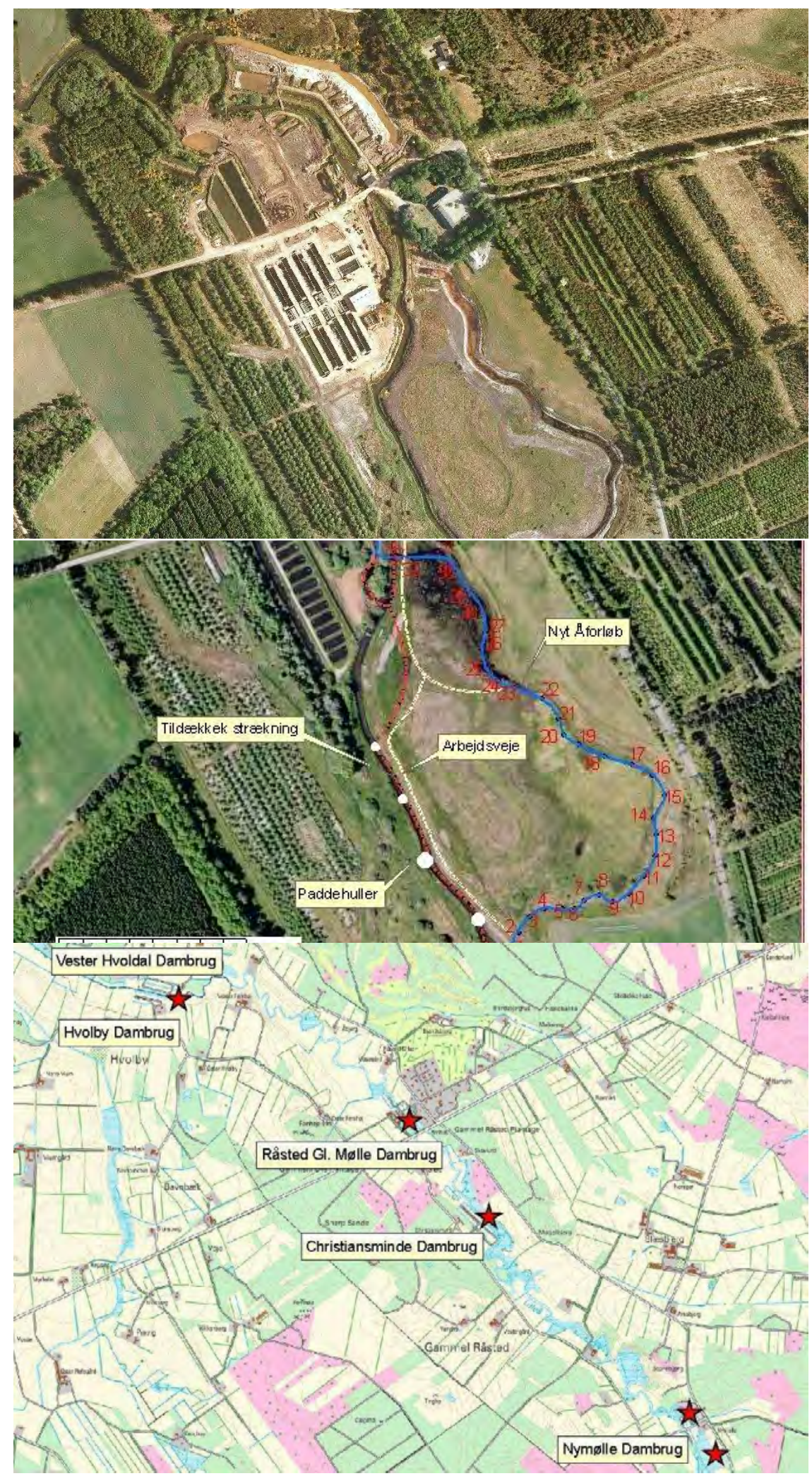

Fig. 47 Nymølle Dambrug, fra plan til udførelse. Projektet ved dambruget er fortsat under udførelse på fotoet. Det faerdige projekt blev indviet juni 2008.

Foto: Holstebro Kommune. 
Opnåede resultater

- Ca. 2,3 km vandløb har fået sine slyngninger tilbage.

- Laks og havørreder på gydevandring i Storåsystemet har fået fri adgang til ca. $23 \mathrm{~km}$ å i Storåens største tilløb.

- Nye gydebanker etableret hvor der før lå dambrug.

- Rentvandsfaunaen er vendt tilbage til åen på hele strækningen fra Nymølle Dambrug til det nederste dambrug, målsætningen er nu opfyldt i Råsted Lilleå.

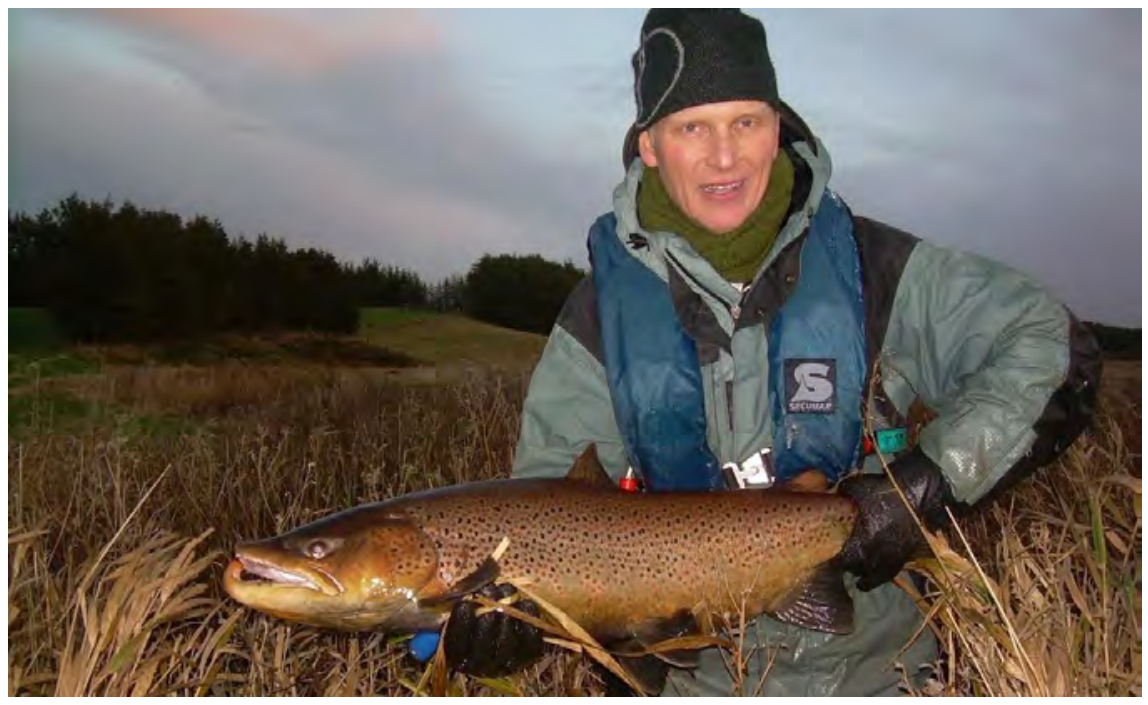

Fig. 48. Laks og havørred på gydevandring (elfiskeri 2008).

Foto: Holstebro Kommune.

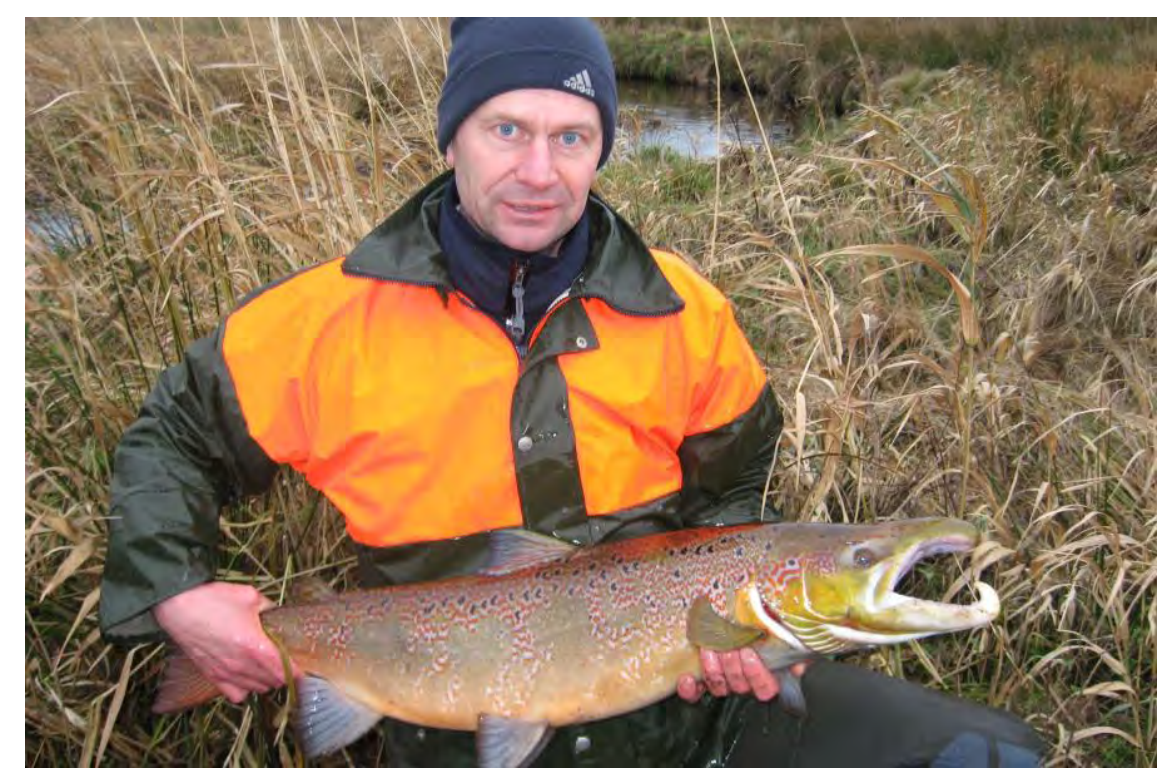

Fig. 49. Storå med tilløb (herunder Råsted Lilleå der er det største tilløb) har en fast bestand af laks og havørreder. Indtil videre er bestandene afhongig af udsctninger. Derfor skal fiskenes mulighed for fri vandring til gydepladser forbedres, så bestandene fremover kan klare sig selv.

Foto: Holstebro Kommune. 
Videre opfølgning

Der er fortsat forhindringer for fri passage i Storåsystemet. Fiskenes frie vandring kan stadig forbedres, og gydepladser etableres.

Holstebro kommune har lavet aftale om nedlæggelse af endnu et dambrug, det gælder Grydeå Dambrug i Gryde Å. Projektet er vedtaget, aftaler overordnet på plads. Projektet udføres i 2010, med tilskud fra Fødevareministeriet.

Den største forhindring for Fiskenes frie vandring i storåsystemet er Vandkraftsøen ved Holstebro by. Holstebro Kommune har planer for en løsning af problemet, og har sendt en ansøgning til Staten om hjælp til projektet, der vil være det største naturforvaltningsprojekt kommunen har deltaget i. Projektet er afhængigt af ekstern finansiering. Der er endnu ikke kommet svar fra staten, så muligheden for gennemførelse på kort sigt er endnu uvis.

\section{Erfaringer}

Der er endnu ikke foretaget systematisk registrering af effekten af projekterne for fisk og lampretter i Råsted Lilleå, men observationer ved åen har allerede vist fisk på leg i de øvre dele af Råsted Lilleå. Som nævnt er der allerede observeret store fremskridt $\mathrm{i}$ insektfaunaen, der er en god indikator for at vandløbet er kommet i økologisk balance.

I december 2009 har Holstebro Kommune planlagt registrering af laks og havørred på leg ved elfiskeri, men erfaringer fra tidligere projekter viser, at der typisk vil gå $3-5$ år inden åen er taget helt $i$ brug af fiskene.

For projekter i denne størrelse er det vigtigt at inddrage det politiske system, og få opbakning fra lokalpolitikerne.

Projekterne har koste ca. 5,5 mio. dkr., hvilket er dyrt for en dansk kommune. Derfor er opbakning og samarbejde med Staten en forudsætning for gennemførelse af projekter i denne størrelse. 

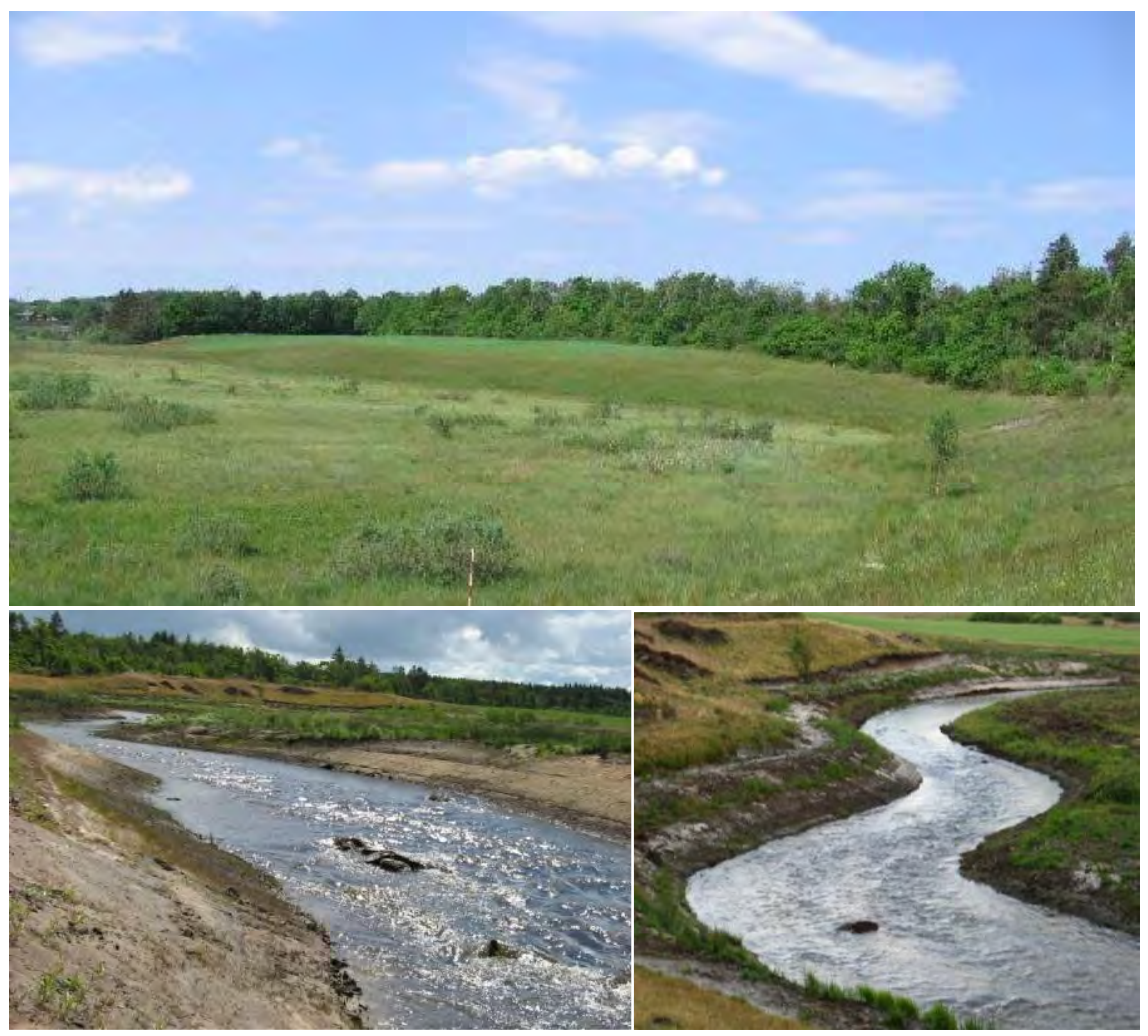

Fig. 50. Ovenfor Nymølle Dambrug før og efter.

Foto: Holstebro Kommune.
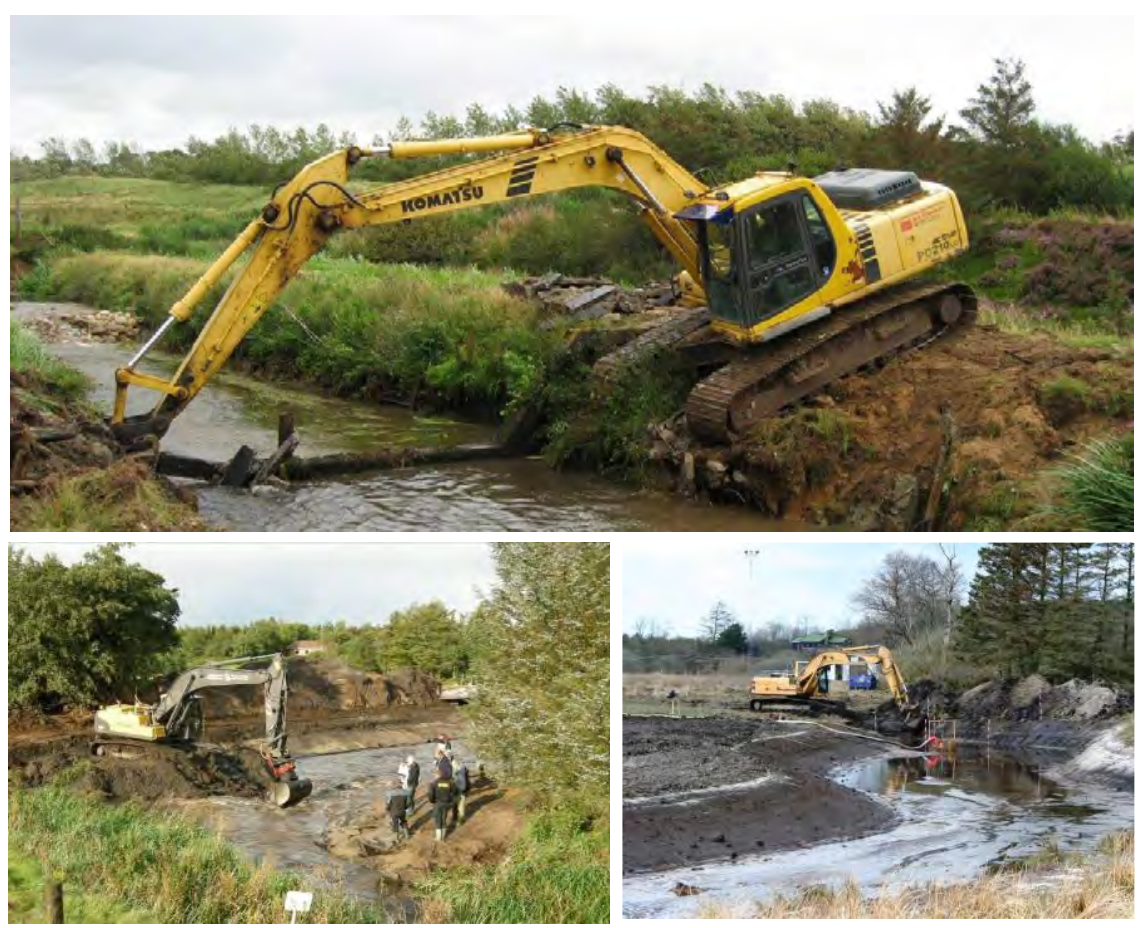

Fig. 51. Nye åløb tages $i$ brug. Foto:

Holstebro Kommune. 



\section{Kolding kommune}

Kolding, en av Danmarks største byer, har svært variert natur. I øst er det morene med leirjord og landskapet er formet av elvedaler og Lillebæltskysten. Lenger nord er jordbunden mer sandet. Mot vest ligger flate hedesletter.

\subsection{Prosjekt 1. Skærsø, Nørremose og Husted Mose - genopretning af sø og tilhørende moseområder}

Skærsø er en såkaldt Lobeliesø, opkaldt efter den i Danmark sjældne og krævende under-vandsplante tvepibet lobelie Lobelia dortmana, som kun trives i næringsfattige, klarvandede søer. Skærsøs tilstand er i dag kritisk, men på trods heraf findes stadig både den rødlistede sortgrøn brasenføde Isoëtaceae lacustris og de gullistede tvepibet lobelie og strandbo Plantaginaceae uniflora. Men planterne er overvokset af et ofte tykt lag af fastsiddende alger, på grund af søens dårlige tilstand. I nogle naturlige vandhuller i bredzonen på nordsiden af Skærsø er der i 2004 fundet bilag IV-arten lys skivevandkalv Graphoderus bilineatus.

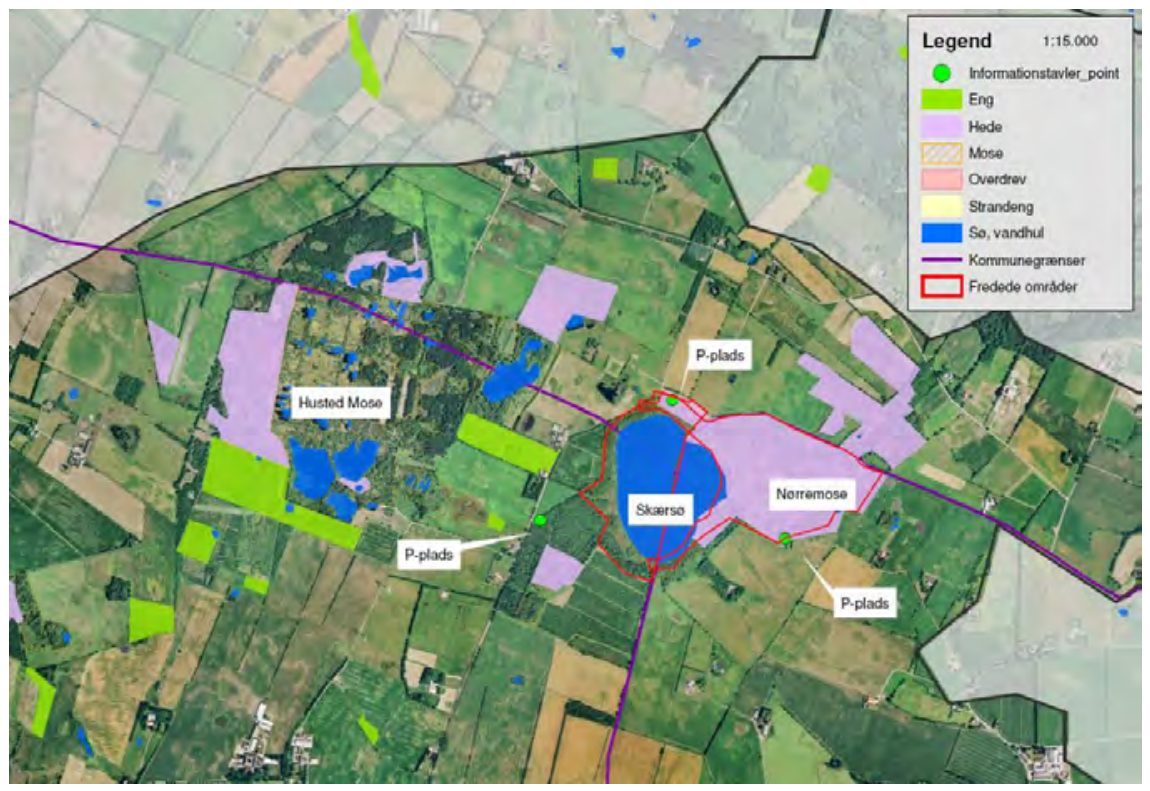

Fig. 52 Projektområde med Skcersø og de 2 tilstødende moseområder Nørremose og Husted Mose.

Foto: Kolding kommune.

Øst for søen ligger Nørremosen, som angiveligt er en tidligere højmose. Tørven blev stort set gravet væk under og lige efter 2. verdenskrig, hvilket 
har betydet, at den vestlige halvdel af mosen i dag fremstår som græshede/hedemose. Her vokser bl.a. alm. Månerude Botrychium lunaria, blærerod Utricularia og liden ulvefod Lycopodiella inundata foruden den meget sjældne svamp kromgul vokshat Hygrocybe vitellina, som kun er fundet få steder i Danmark. I mosens østlige del er der en særdeles bevaringsværdig hængesæk med tilhørende flora bl.a. hvid næbfrø Rhynchospora alba, rundbladet og liden soldug Droseraceae. I Nørremosen og sandsynligvis Husted Mose yngler trane (fredet og på fuglebeskyttelsesdirektivets artikel 1).

Husted Mose er et stort moseområde på omkring 70 ha beliggende umiddelbart vest for Skærsø. Husted Mose består især af mange tørveskærshuller og tørveskrabs-flader. Mange af tørvegravene er delvis vandfyldte eller regulære søer. I de fugtigste dele findes hedemose og forskellige fattigkærssamfund domineret af henholdsvis tørvemosser og blåtop Molinia caerulea med f.eks. kragefod Comarum palustre, liden soldug, rundbladet soldug, klokkelyng Erica tetralix, rosmarinlyng Andromeda polifolia, hvid næbfrø, liden siv Juncus bulbosus, mosepors Myrica gale samt tue- og smalbladet kæruld Eriophorum. De ydre dele af Husted Mose er afvandede og domineret af blåtop med indslag af hedelyng og klokkelyng med opvækst af pil, birk og gran. Mosen er overalt under tilgroning med især birk, men egentligt birkekrat findes endnu kun i mosens perifere dele. Dele af mosen er under tilgroning med bjerg-fyr.

Op til 1987 havde Skærsø en meget fin tilstand med helt klart vand og en veludviklet undervandsvegetation, I 1988 skete der en pludselig forringelse af søens tilstand. Vandet blev uklart og har været sådan siden trods flere forsøg på at forbedre tilstanden.

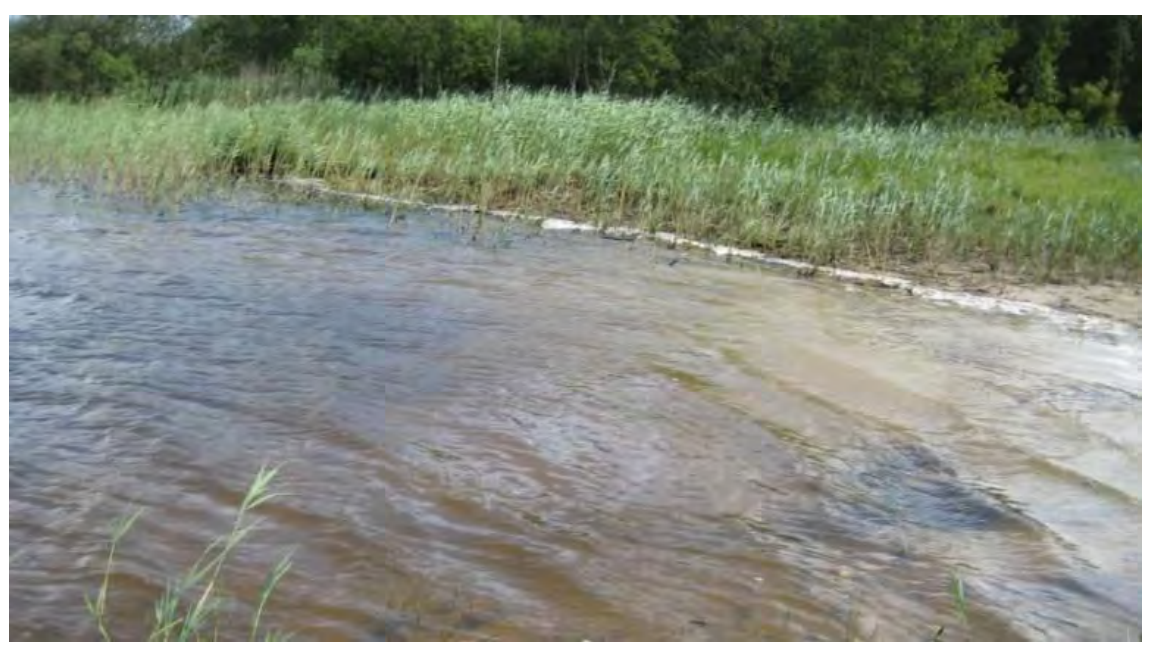

Fig. 53. Undersøgelser har vist, at undervands-vegetationen er blevet trangt tilbage og at rørsumpen visse steder er blevet toettere. Alle de sjoeldnere arter er dog stadig til stede i søen. Foto: Kolding kommune.

Årsagen til søens pludselige forringelse i miljøtilstand har formentlig flere forklaringen, men nye undersøgelser tyder på at omdrejningspunktet for den pludselige tilstandsændring, den vedvarende dårlige vandkvalitet, og ude- 
blevne effekter af adskillige restaureringstiltag, synes primært at være tilførsel af humusstoffer fra kilder i søens umiddelbare nærhed.

\section{Samarbejdspartnere}

For at genoprette søens miljøtilstand er der igangsat et projekt i et samarbejde mellem Skov- og Naturstyrelsen, Vejen Kommune, Vejle Kommune og Kolding Kommune idet søen administrativ ligger i alle 3 kommuner. Skovog Naturstyrelsen er lodsejer ved søen. Alle parter bidrager økonomisk til projektet.

Projektet har desuden et godt samarbejde med forskere fra Ferksvandsbiologisk Laboratorium og GEUS (Danmarks og Grønlands Geologiske Undersøgelser), der i øjeblikket er med i et forskningsprojekt omhandlende lobeliesøer og deres miljøtilstand.

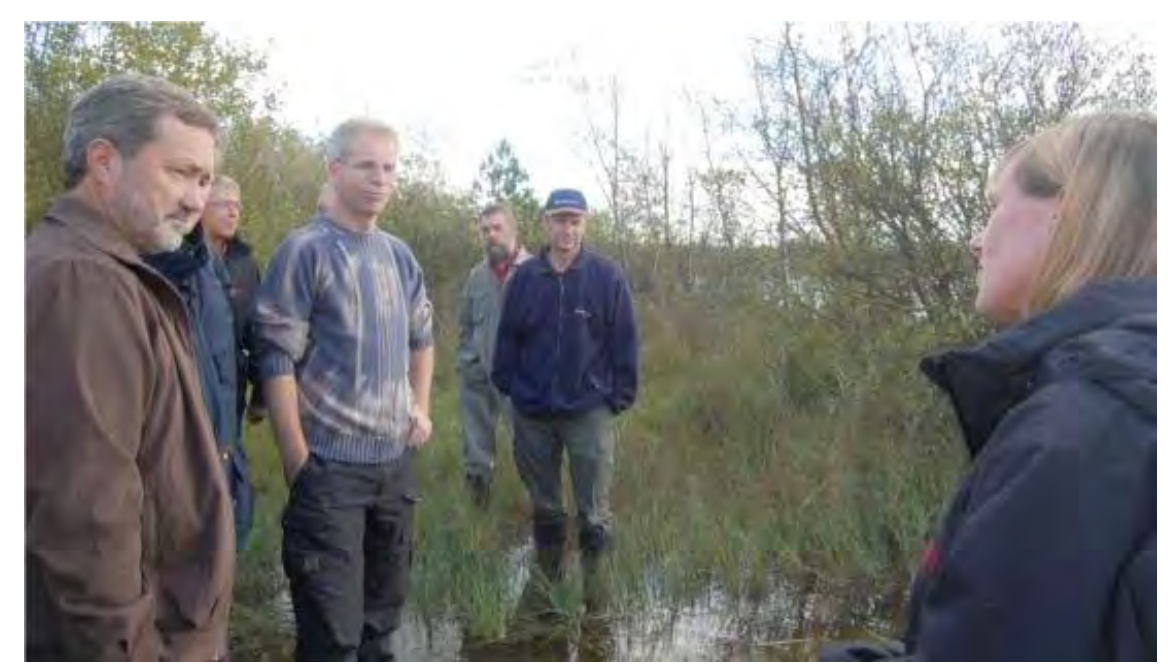

Fig. 54 Ekskursion ved Skcersø ved nordisk 2010-projektmøde sommeren 2007.

Foto: Kolding kommune.

\section{Målscetning}

- Miljøtilstand forbedres inden for en 10-årig periode, så søen bevares som lobeliesø

- Inden for en 10 årig periode skal udbredelsen af grundskudsplanter øges, og nå $80 \%$ af udbredelsen før 1987

- Sammensætningen af fiskearter, zoo-og planteplankton svarer til det normale for en lobeliesø

- Den del af oplandet til Skærsø, som i dag er under tilgroning, er lysåben og næringsfattig natur

- Området mellem Skærsø og Husted Mose er sikret som ny natur eller ekstensivt landbrugsjord

- Styrkelse af oplevelse og formidling af områdets værdier 


\section{Gennemførte tiltag}

Der er udarbejdet en masterplan for søen med plan for fremdrift på kort og lang sigt.

Tiltag på kort sigt (udført eller under udførelse):

- Oprensning af søens afløb for at sikre fastholdelse af søens vintervandstand, så oversvømmelse af de lavtliggende arealer rundt om søen undgås. (tilførsel af humusholdigt vand).

- Afskæring af tilførsel til søen af humusholdigt vand via grøfter og dræn

- Rydning af opvækst i udsigtskiler, badestrand og Nørremosen.

- Udskiftning af hegn og opsætning af forsøgshegn ned til søen ved Nørremosen

- Opretholdelse af græsning i Nørremosen

- Rydning og forbedring af rekreativ sti rundt om søen

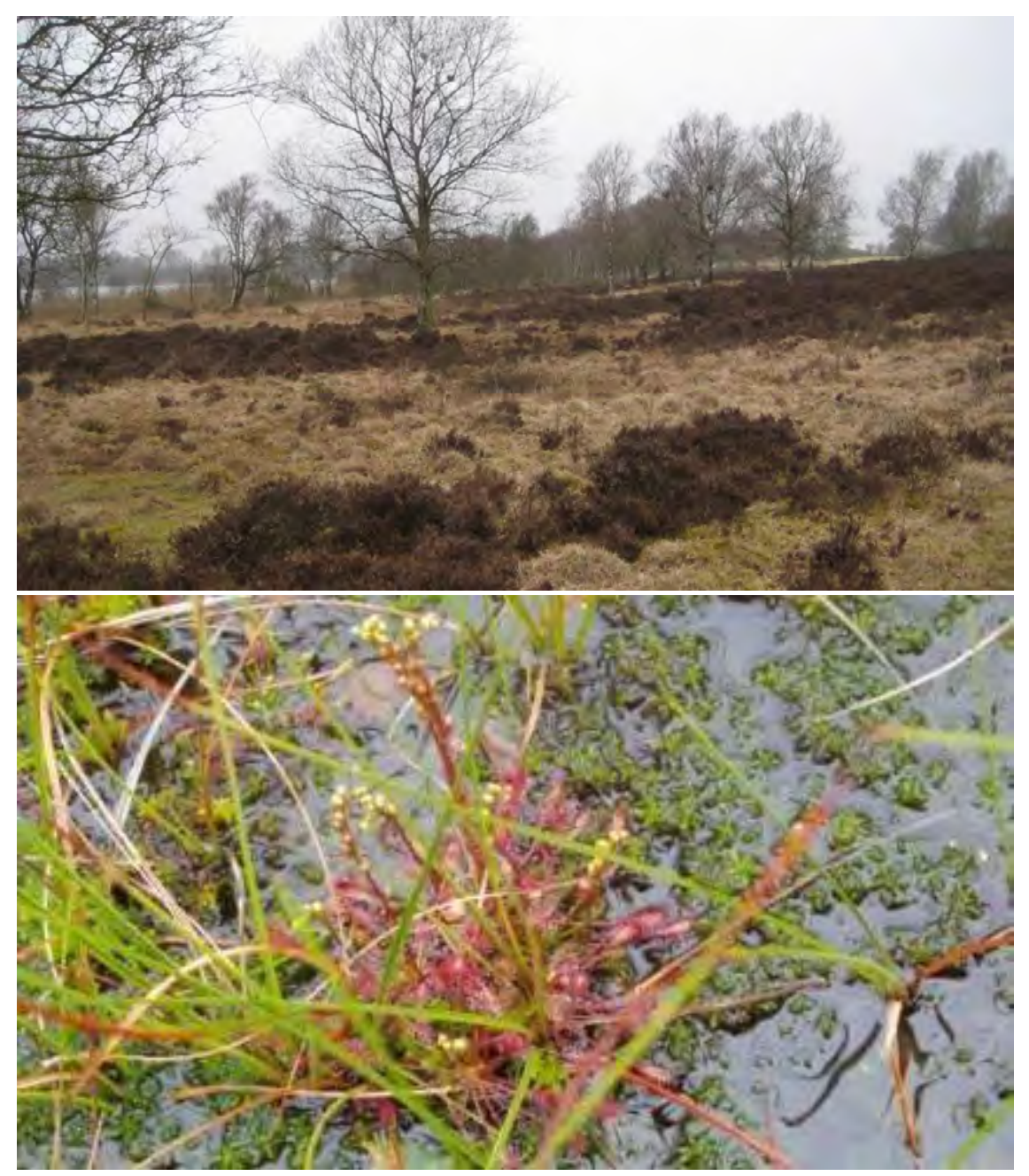

Fig. 55. Nørremosen med Skcersø i baggrunden. I Nøremosen vokser liden soldug. Foto: Kolding kommune. 


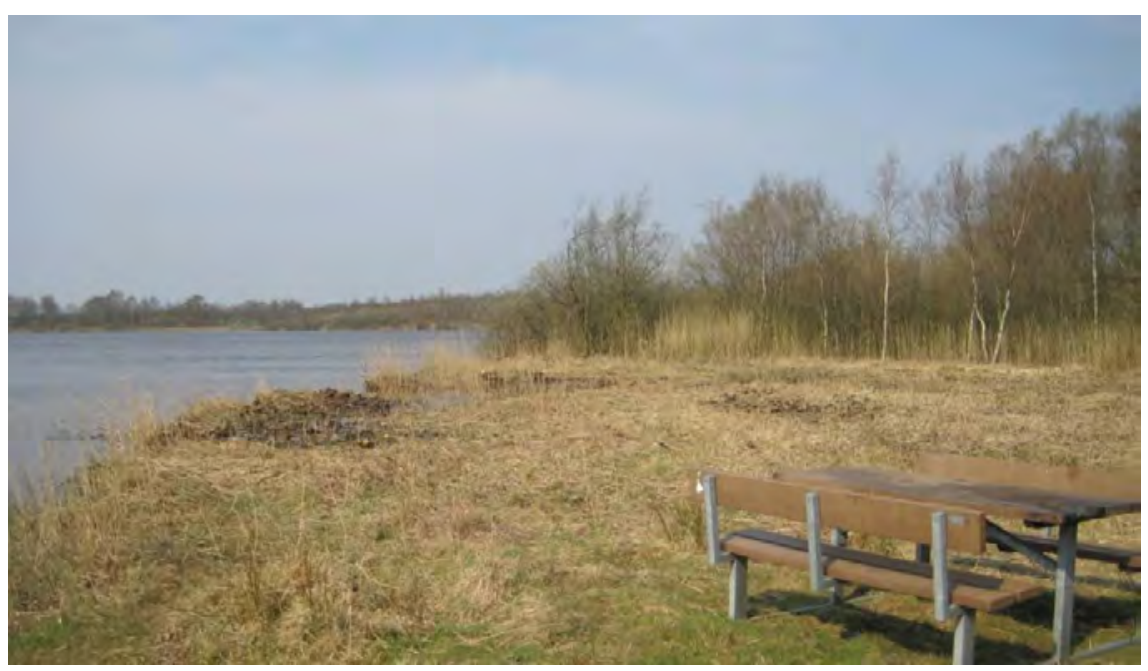

Fig. 56 Udsigtskile ved søens badested.

Foto: Kolding kommune.

\section{Opnåede resultater}

Nørremosen er ryddet for opvækst og nyt kreaturhegn opsat. Hermed er Nørremosen sikret for en tid frem som lysåben natur gennem afgræsning. Der har tidligere været afgræsset med får og senere kreaturer. Lige nu går der heste med stor succes. Der vil udover tilsynet med dyrene være behov for løbende vedligeholdelse af hegnet og med mellemrum efterrydning af det grovere opvækst, som dyrene ikke kan holde nede.

Forsøgsvis er et areal helt ned til søen indhegnet til afgræsning. Målet er at få mere af søens tilstødende arealer ind i en græsningsdrift, for dermed at få en mere lysåben natur til gavn for det tilstedeværende plante og dyreliv. Eventuel negativ effekt på søens tilstand skal dog nøje følges.

Stien rundt om søen er ryddet for opvækst og nogle steder forlagt til mere fast og tørt underlag. Gangbro igennem moseområde er udbedret. Søens badested og flere udsigtskiler fra stien ud mod søen er ryddet. Hermed er skabt bedre forhold for besøgende. Stien vil fortsat skulle holdes fri for opvækst og gangbroer vedligeholdes. Eventuelt skal stien med års mellemrum flyttes for at udnytte positiv slid i forhold til beplantning.

\section{Videre opfølgning}

Vejen Kommune, Vejle Kommune, Skov- og Naturstyrelsen Trekanten og Kolding Kommune overvejer i øjeblikket nødvendige tiltag for genopretning af søen og mulige finansieringskilder.

Vejen Kommune arbejder på projekt i Husted Mose.

\section{Erfaringer}

Potentialerne i et naturområde, der ligger på en administrativ grænse kan nemt blive overset, da myndighederne kan komme til udelukkende at koncentrere sig om egne arealer. Men er samarbejdet først etableret kan det modsat også være en fordel, hvis man forstår at udnytte kompetencerne hos 
hver af de administrative myndigheder. Dog svært at etablere hurtig beslutningsproces.

Tidligere tiders overvågningsresultater har været en vigtig kilde til at analysere Skærsøs miljøproblemer og mulige genopretningstiltag. Uden overvågning vil vi famle i blinde, ligesom at det er vigtigt at effekten af nuværende og kommende tiltag følges og efterfølgende analyseres. Samarbejde mellem forskningsinstitutionerne og de administrative enheder har været meget givtigt.

Finansieringen af naturgenopretningsprojekter er i Danmark i stigende grad afhængig af EU's tilskudskasser. Skærsø er et eksempel på et naturområde som trods høj biologisk værdi falder mellem ,tilskuds-stolene“ da området ikke har status af habitatområde, og ej heller handler om at begrænse udslip af næringsstoffer fra landbrugsareale
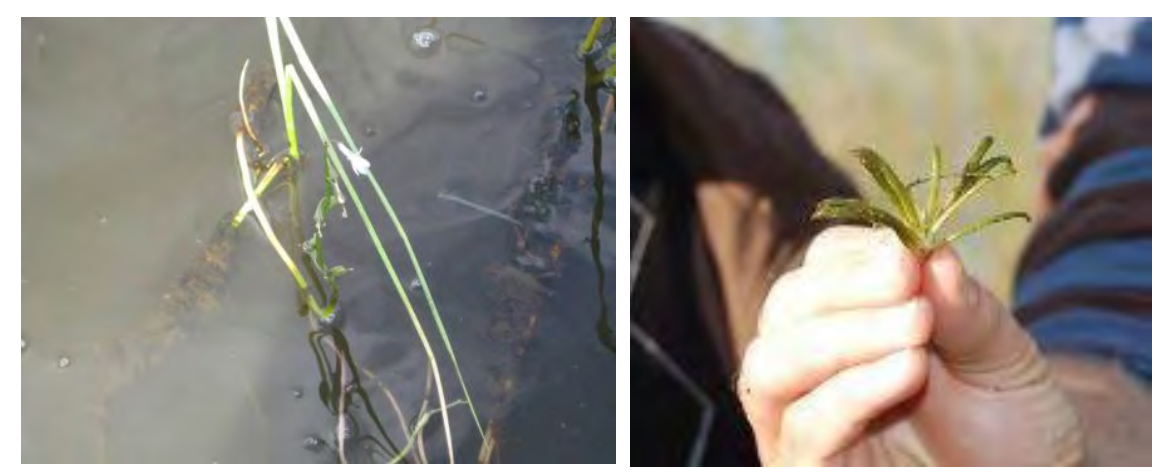

Fig. 57 Tvepibet Lobelie (Lobelia dortmana).

Foto: Kolding kommune.

\subsection{Prosjekt 2. Åkær $\AA$ - genopretning af vandløb og etablering af vådområder}

Åkær Å løber i et meget kuperet terræn og er karakteriseret ved et fint snoet og naturligt forløb med god iltning af vandet. Åen modtager vand fra Skærsø samt fra et stort intensivt dyrket landbrugsområde. Åen er A-målsat og har en lav forurenings-grad, men er især i den øverste ende kraftig belastet af sand fra tilløb og dræn. De væsentligste tilløb er Jordrup Bæk, Hundsholt Bæk og Tanggård Bæk, som mange steder ikke lever op til deres målsætning som B1 vandløb pga. dårlige fysiske forhold. Mange af de omgivende enge, overdrev og moser er vigtige botaniske lokaliteter, idet der træder mange kildevæld ud af bakkerne omkring åen.

I 2007 har Kolding Kommune fået bevilliget ca. 10 mio. kr. fra „,miljømilliarden“ til at etablere genslygninger samt udlægge sten og grus på en 17 $\mathrm{km}$ lang strækning i vandløbssystemet. Formålet er at skabe flere levesteder for smerling og ørred (rødliste arter) samt bæklampret og odder, der begge er opført på Habitatdirektivets bilag IV. 
Videre skal moserne i oplandet til Åkær Å genskabes ved tilstopning og afskæring af dræn samt ved at genskabe det hydrologiske samspil mellem vandløbene og de ånære arealer. Med nye vådområder og moser kan kvælstofbelastningen af Kolding Fjord og NATURA 2000 område, Lillebælt begrænses med 9 tons kvælstof årligt og der kan skabes bedre levevilkår for løvfrøen, der er opført på Habitatdirektivets bilag IV.

Desuden skal der ske en rydning og græsning af de lysåbne natyrtyper i oplandet til vandløbssystemet. Der findes i dag enkelte rigkær (svarende til habitat-naturtype 7230), et kalkoverdrev (svarende til habitatnaturtype 6210), urtebræmmer (svarende til habitatnaturtype 6420) samt aske- og ellesumpe (svarende til habitatnaturtype 91Eo).

\section{Samarbejdspartnere}

Projektet foregår i et samarbejde mellem Skov- og Naturstyrelsen, den lokale landbrugsforening Kolding Herreds Landbrugsforening og Kolding Kommune og i tæt dialog med de berørte lodsejere.

Målscetning - 5 år efter projekttiltagenes gennemførelse tilstrcebes at følgende mål er opfyldt:

- $80 \%$ af Åkær Å med tilløb opfylder fremtidige krav til god økologisk status efter vandrammedirektivet for de fysiske forhold. Forekomst af mindst 2 par ynglende Odder

- Øget forekomst af Bæklampret i Åkær Å og tilløb.

- Øget forekomst af den rødlistede Smerling i Kolding Å systemet.

- Fordobling af bestanden af den genetisk oprindelige ørred (rødlistet) $\mathrm{i}$ Kolding Å systemet.

- Øget forekomst af Løvfrø i Åkær Å oplandet.

- Øget diversitet af dyr og planter, der er karakteristiske vådbundsarter på ånære arealer.

- Øget diversitet af dyr og planter, på eksisterende naturarealer.

\section{Gennemforte tiltag}

Følgende elementer er afsluttet i 2009:

- Etablering af minivådområde ved Åkær $\AA$ (0,08 ha).

- Realisering af vådområdeprojekt (genskabelse af hydrologisk samspil) ved Røjskov på ca. 20 ha.

- Genslyngning af tilløb, udlægning af gydegrus og etablering af fri passage i Jordrup Bæk. Endvidere overrisling med dræn til minivådområde ( 0,1 ha) ved tilløbet til Jordrup Bæk

- Alle lodsejeraftaler vedr. vådområdeprojekter indgået pr. 1. januar 2010

I forbindelse med etablering af vådområder arbejdes der for samtidig at etablere græsning på de våde enge. På udvalgte lokaliteter langs vandløbssystemet ( $\$ 3$ enge/overdrev) vil der ligeledes blive arbejdet for etablering af 
naturpleje i form af græsning. På en enkelt lokalitet på 3,70 ha indgåes 15årig aftale med plejepligt. Hvor muligt etableres 5-årige græsningsaftaler gerne ophængt på Miljøaftaler via DFFE. Naturpleje i form af afgræsning vil kræve en løbende opfølgning fra kommunen i form af opfordring til afgræsning og evt. hjælp til hegning og rydning, samt etablering af kontakt mellem lodsejer og dyreholder.

\section{Opnåede resultater}

Alle tiltag, der er gennemført i 2009 er endnu så nye, at der ikke kan vurderes på de opnåede resultater endnu. Dog kan det nævnes, at der er konstateret gydning af havørreder i det nyetablerede tilløb til Jordrup Bæk, ligesom der er konstateret gydning af havørreder i de nyudlagte gydebanker i Jordrup Bæk. De etablerede minivådområder vil først effektivt begynde at fjerne kvælstof, når der er sket opvækst af vegetation i dem.

\section{Videre opfølgning}

Tiltag i 2010:

- Etablering af i alt 44 ha vådområder

- Forbedring af fysiske forhold (Åkær Å, Jordrup Bæk, Hundsholt Bæk, Tanggård Bæk)

- Etablering af 3 konstruerede vådområder (et ved Åkær Å, to ved Tanggård Bæk). Etableringen vil ske i samarbejde med Orbicon, der vil lave en efterfølgende effektovervågning, for at dokumentere effekten af de konstruerede vådområder.

- Etablering af græsningsfællesskaber og støtte til førstegangspleje og hegning i projektområderne og langs Åkær Å i øvrigt.

Det har ikke været muligt at skaffe finansiering til opfølgende generel overvågning. Kolding Kommune udfører en simpel opfølgning bl.a. via måling af kvælstof på udvalgte steder i vandløbssystemet for at følge op på effekt af kvælstof-omsætning i de udlagte vådområder.

\section{Erfaringer}

Lokal forankring og inddragelse af lodsejerne i udformningen af projekterne har været en forudsætning for succes.

Flere projekter er justeret og ændret som følge af lodsejerønsker. Nye projekter er opstået som følge af forslag fra lodsejere.

Det er nødvendigt at have tilstrækkelig „modningstid“ (tid, hvor lodsejerne har tid til at tænke over projekterne, og hvor man kan få fundet en løsningsmodel, der gør, at en ellers negativ lodsejer vælger at deltage i projektet). 


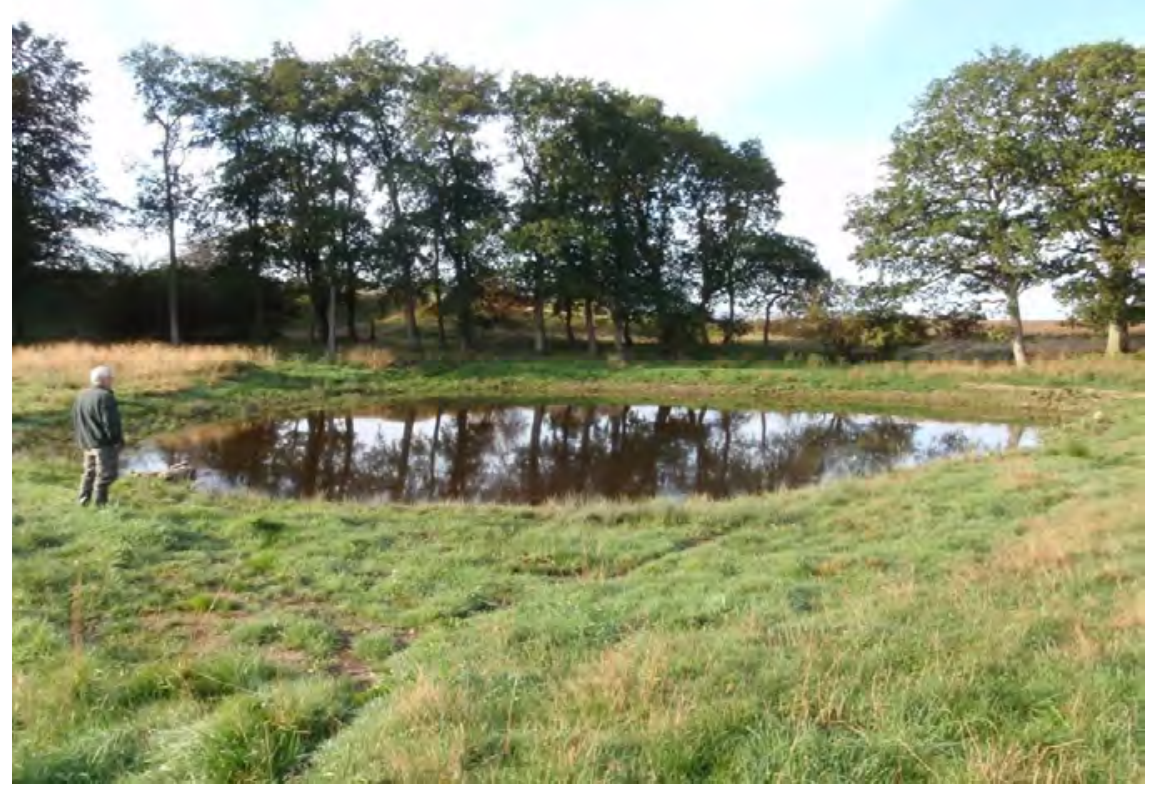

Fig. 58 Mini vådområde ved Åkar A.

Foto: Kolding kommune.

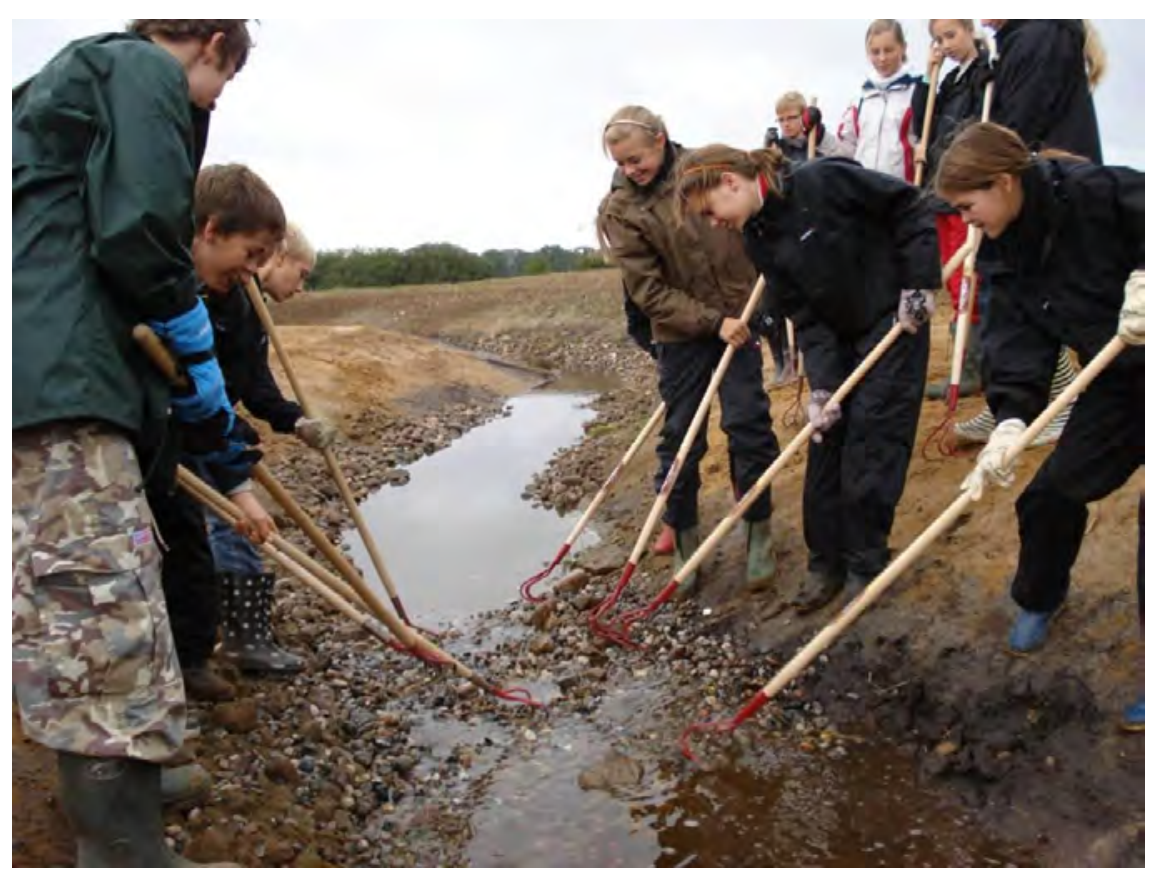

Fig. 59. Vandløbsrestaurering som skoleprojekt. Udlagning af grus og sten i tilløb til Åkar A.

Foto: Kolding kommune. 



\section{Nes og Runavík kommuner}

Nes og Runavik er nabokommuner i Færøyenes vækstcenter. Der er planlagt en undersøisk tunnel fra hovestadsområdet til Runavik. Tunnelutgangen kommer du lige ved kommunegrænsen til Nes og søen Toftavatn som er et viktig område med hensyn til biologisk mangfoldighed.

\subsection{Projekt 1: Toftavatn - Natur, oplevelser og trivsel}

\section{Projektbeskrivelse}

Projektet er et naturbevaringsprojekt i området ved ferskvandsøen Toftavatn på Eysturoy, Færøerne.

Toftavatn ligger i den sydlige del af Eysturoy, den næststørste af Færøernes øer. Søen ligger på kommunegrænsen imellem nabokommunerne, Nes og Runavík, og derved ligger området inde på begge kommuners område.

Området ligger i det største og bedst udviklede lynghede-område på Færøerne, som dækker en stor del af Syd-Eysturoy. Lynghede dækker $26 \mathrm{~km} 2$ eller ca. $2 \%$ af arealet på Færøerne. Tidligere er der været observeret forskellige sjældne fuglearter i området, bl.a. Lom (Gavia stellata). En egentlig kortlægning af området, mht. biologisk mangfoldighed, har dog ikke været gennemført før i forbindelse med dette projekt i 2009.

I forbindelse med planer om udstykning af grunde til bebyggelse i nærheden af søen, ved Høganes, og planer om anlæggelse af en trafikvej i søens nordlige ende, har Nes- og Runavík kommuner sat dette projekt i gang for at bevare Toftavatn-områdets status som en naturperle i området, samt for at give offentligheden adgang til området under kontrollerede forhold.

Projektet er til i samarbejde med Naturdirektoratet, Náttúrugripasavnið, og Lokal Agenda 21 kontoret, Agenda 21 stovan og har været ledet af en styregruppe med medlemmer fra kommunerne og Agenda 21 stovan. 


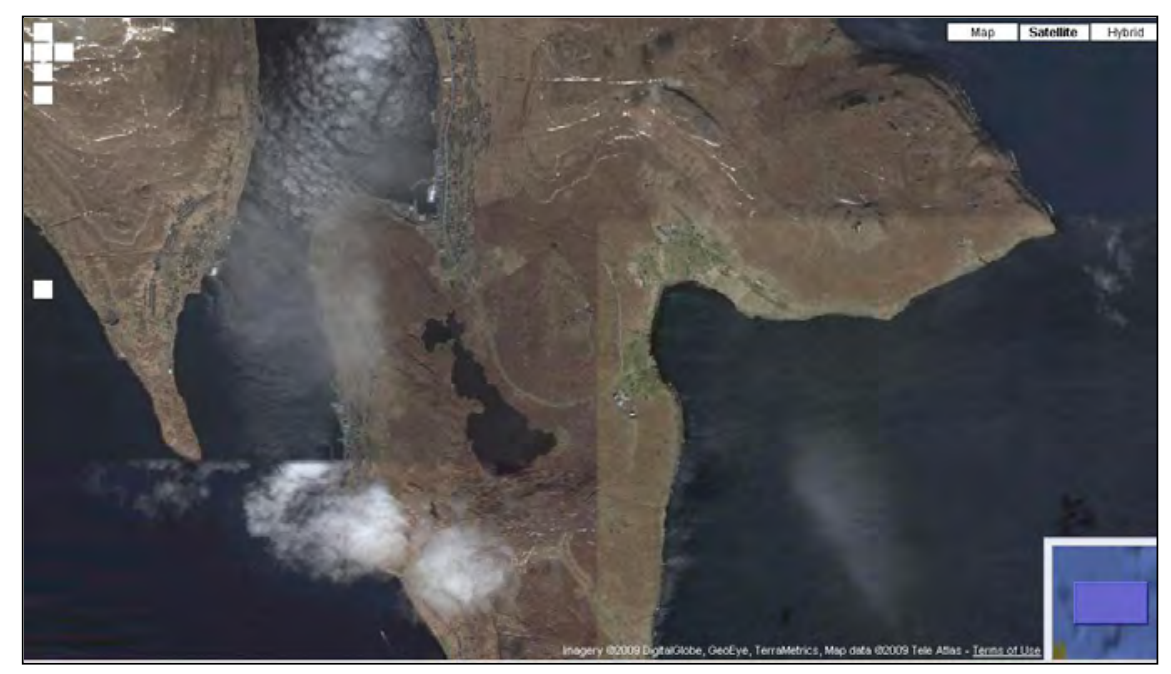

Fig. 60. Satelittfoto af den sydlige del af Eysturoy. Toftavatn ligger i midten af billedet. Projektet har fokus på søens nordlige del (cirkel). Søens sydlige del kommer til at ligge som naturreservat.

Foto: Nesvik og Runavik kommuner.

\section{Projektets mål i forhold til biologisk mangfoldighed}

Projektets formål er:

1. Registrering af mangfoldighed

- At skaffe eksakt viden om området og dermed øge om vidensgrundlaget for bevarelse af områdets naturlige, historiske og biologiske mangfoldighed.

2. Kontrolleret offentlig adgang til området

- At skabe kontrollerede rammer for folks færden i området og et oplevelsessted for besøgende.

3. Formidling af informationer om områdets mangfold

- At skabe oplysning til offentligheden og besøgende om områdets særlige naturlige karakteristika, biologiske mangfoldighed og kulturhistorie.

\section{Tiltag gennemført}

Herunder følger en uddybning for hvert af de konkrete tiltag, som tilsammen udgør projektet. Målet er at alle tiltag er færdige i sensommeren 2010. Kortloegning og skiltning om områdets natur, historie og biologi

I forbindelse med projektet er dyre- og plantelivet og historiske samfundsrelaterede steder i området i gang med at blive kortlagt. Naturdirektoratet står for kortlægningen af den biologiske mangfoldighed i området. Faglig ekspertise på Agenda 21 stovan står for kortlægningen at områdets geografi og geologi, mens den lokalhistoriske forening, Nes fornminnisfelag, står for kortlægningen af de historisk interessante steder.

Målet er at det samlede materiale fra kortlægningen ligger klar i maj 2010. 


\section{Anloeggelse af sti-system}

Et stisystem er delvist anlagt i området. Stisystemet bliver anlagt i samarbejde med natur- og fredningsmyndigheder og i henhold til at lede besøgende udenom særligt følsomme og sjældne dyr og planter, samtidig som den besøgende får oplevelsen af at gå i dette særlige naturområde.

Første del af stisystemet, fra Runavík og til området ved søen, var færdigt i 2008. Resten af stisystemet afventer resultatet fra kortlægningen og ventes påbegyndt i foråret 2010. Målet er at stisystemet er færdigt og taget offentligt $\mathrm{i}$ brug i september 2010 .

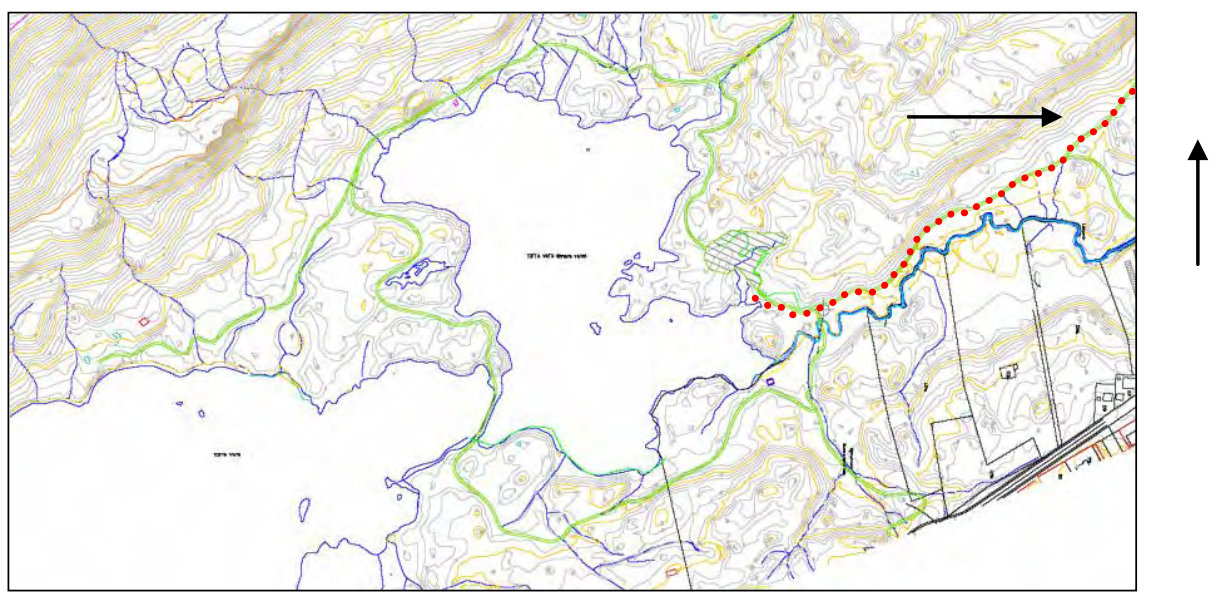

Fig. 61 Topografisk kort over den nordlige del af Toftavatn. Den stiplede røde linje indikerer stien anlagt $i 2008$ og den grønne linje det planlagde stisystem. Den samlede loengde af stisystemet er $2,7 \mathrm{~km}$.

\section{Skiltning og udarbejdelse af info-materiale}

I forbindelse med anlæggelsen af stisystemet vil der blive sørget for relevant skiltning om områdets plante- og dyreliv, samt historie. Skiltningen sker i overensstemmelse med estetiske forbehold, således at skiltene ikke påvirker stedets naturlige skønhed.

Skilte ventes sat op i sommeren 2010 .

Projektet frem til 2010

Nedenfor ses en oversigt over projektets tiltag til sept. 2010, når projektet afsluttes. Ifølge tidsplanen er projektet derfor stadig i gang ved deadline til denne afrapportering, som er 1. des. 2009.

\begin{tabular}{|c|c|c|c|}
\hline Delprojekt & Udføres af & Status & Færdigt \\
\hline \multirow{3}{*}{$\begin{array}{l}\text { Biologisk kortlægning af området } \\
\text { Kortlægning af historisk interessante } \\
\text { steder }\end{array}$} & NGS & I gang & Ultimo 2009 \\
\hline & Nes forminnisfelag og & & \\
\hline & Agenda 21 stovan & I gang & Maj 2010 \\
\hline Anlæggelse af stisystem i området & Kommunerne & I gang & Sept. 2010 \\
\hline Infomateriale og skilte & Kommunerne & I gang & Sept. 2010 \\
\hline Officiel åbning af området & Kommunerne & Ikke startet & Sept. 2010 \\
\hline
\end{tabular}




\section{Opnåede resultater}

Den biologiske kortlægning af området vil give et helhedsbillede over den biologiske mangfoldighed i et færøskt lyngområde. Området er under kortlægningen blevet belyst kvantitativt i henhold til udbredelse af fuglearter, insekter og planter. Dette er ny viden, som ikke før har eksisteret i færøsk kontekst.

Under kortlægningen er der blevet påvist sjældne planter, bl.a. Spæd arve (Anagallis tenella) og Lund - Fredløs (Lysimachia nemorum).

I samarbejde med den lokalhistoriske forening er der påvist flere historiske og arkæologiske spændende steder i området. Her kan nævnes kunstige holme i søen, som blev anlagt i 1800 tallet for at fremme ederfuglenes bevarelse i området, en historisk tiltag for bevarelse af den biologiske mangfoldighed, da ederdun i den tid sås som en vigtig naturressource. Et andet levn af historisk interesse er skyttegrave fra 2. Verdenskrig, som var en del af det britiske forsvar af Sydeysturoy.

Den del af stisystemet, som hidtil er færdigt har givet lokale beboere delvis adgang til området ved søen. Stien bliver jævnligt brugt f.eks. af børnehaver og friluftsfolk.

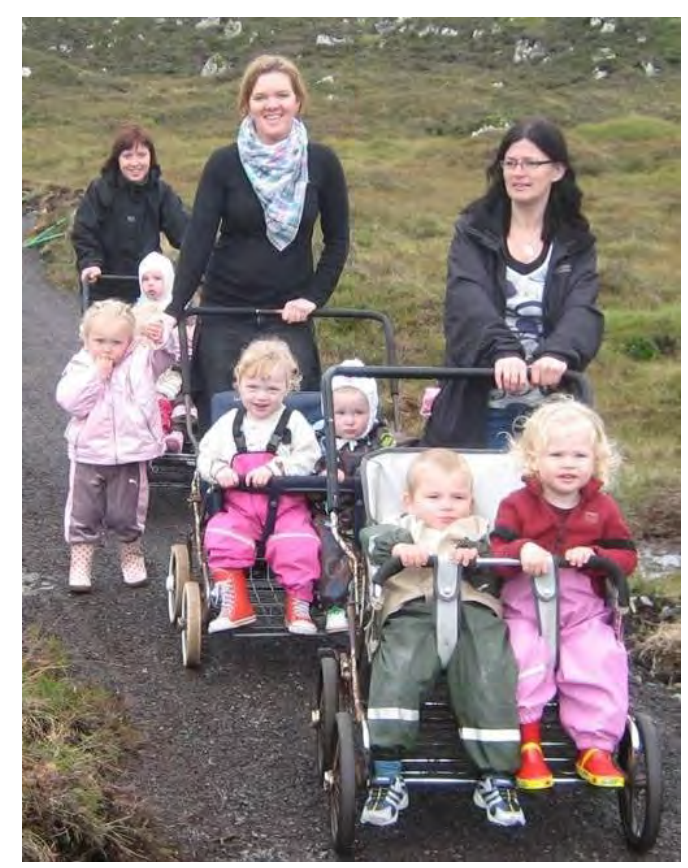

Fig. 62 Stien i området er populcer både blandt yngre og celdre friluftsfolk. Foto: Nesvik og Runavik kommuner.

\section{Videre opfølgning}

Set i fremtidsperspektiv er muligheder for at have naturvejledere tilknyttet området på freelance basis. Der er i denne sammenhæng på tale, at arrangere et samarbejde med kommunerne, touristkontoret i området og Færøsk Onitologforening. 


\section{Erfaringer}

I et lille samfund som Færøerne viser dette projekt, når det er tilendebragt 2010, at det er muligt for små kommuner, Nes 1200 indb. og Runavik 3600 indb., i samarbejde lokale og nationale aktører, at løfte et sådant projekt. Lokal og faglig kunnen har været grundlaget under projeket og kommunerne har stået for finansiering og projektstyring.

Naturen respekterer ikke administrative- og kommunegrænser. Projektet viser i dette henseende, at samarbejde imellem kommuner om naturbevaringsprojekter i områder, som overlapper kommunegrænser er muligt. Vigtigt i dette projekt har været, at involvere beggei kommuner og danne en fælles kommunal styringsgruppe tidligt i forløbet. Styringsgruppen har haft kontakt med myndigheder, relevante aktører og det kommunale bagland under hele projektforløbet. 



\section{Stjørdal}

Stjørdal har store variasjoner i naturforhold. Sjø og marine strandområder langs Trondheimsfjorden, høgfjell (1171 moh) i indre deler av kommunen og Stjørdalselva med sine verna sideelver Sona og Forra gir grunnlag for et rikt biologisk mangfold. Stjørdal er også en småby i vekst og Midt-Norges hovedflyplass er plassert her.

\subsection{Prosjekt 1 Kulturlandskap i Forradalen}

Prosjektbeskrivelse

Forradalen er ei jord- og skogbruksbygd med mange artsrike slåtteenger og beitemarker. På enkelte eiendommer forekommer det fortsatt tradisjonelt slåttebruk med liten eller ingen bruk av kunstgjødsel.

Som de fleste andre steder, er kulturlandskapet i endring og det biologiske mangfoldet trues av gjengroing som følge av at slått og beite har opphørt eller har blitt kraftig redusert.

I tillegg til de biologiske verdiene i Forradalen var det en betydelig interesse i lokalsamfunnet for å bevare verdiene i kulturlandskapet.

Med dette som utgangspunkt ble det i 2004 etablert et prosjekt som tok sikte på å bevare kulturlandskapsverdiene i Forradalen gjennom skjøtsel og restaurering. 


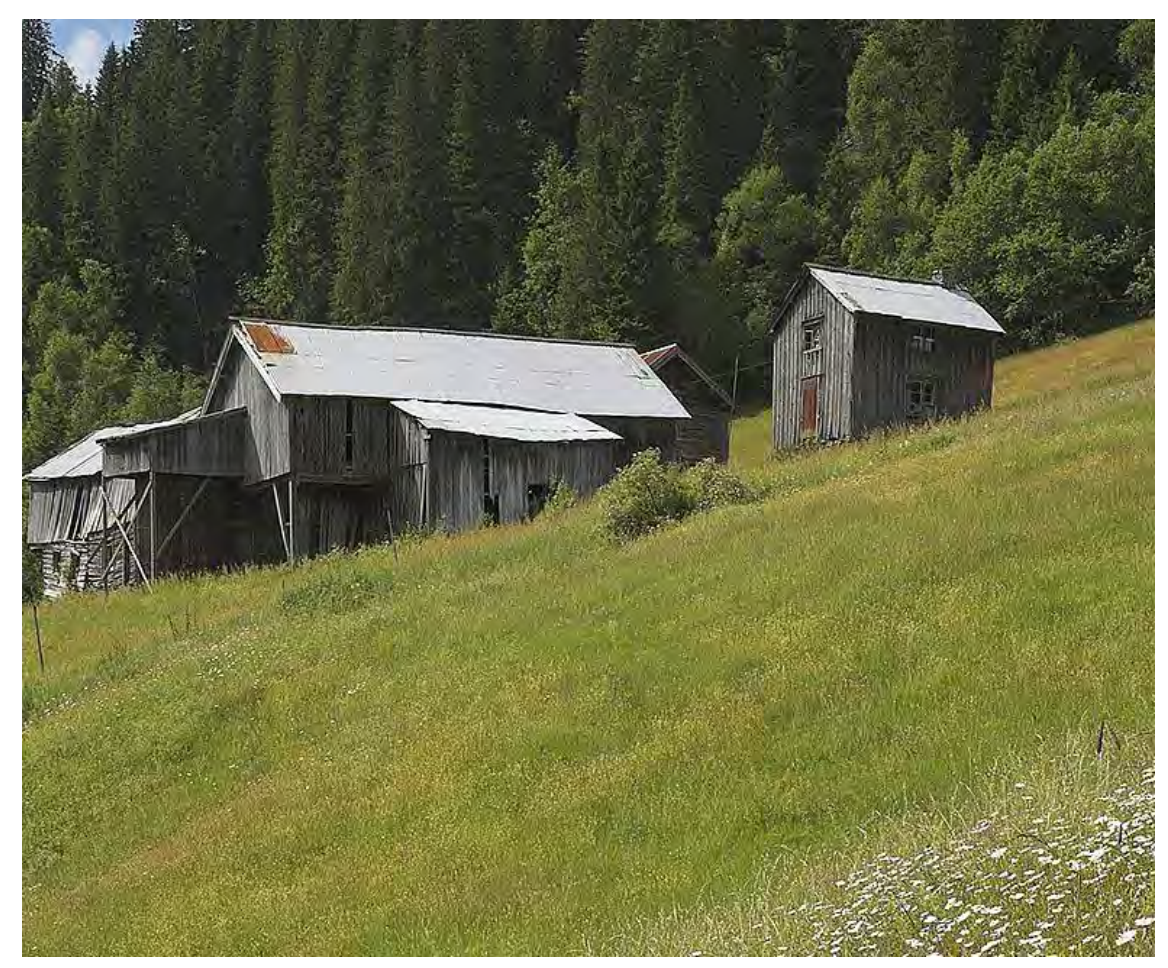

Fig. 63 Forradalen utmerker seg med sine mange rike slåttenger.

Foto: Stjørdal kommune.

Det ble etablert et mobiliseringsprosjekt som tok sikte på å etablere et kunnskapsmessig grunnlag for kulturlandskapsforvaltninga. Det ble gjort ei faglig registrering av flora og vegetasjon, samt kulturminneregistrering på de enkelte gårdsbruk. Det ble dessuten holdt kurs og fagdager som skulle gi øk gi økt kompetanse og motivere til å skjøtselstiltak på det enkelte gårdsbruk. Planteforsk, Kvithammer ble engasjert til å utføre registreringer og gi faglig bistand.

Med utgangspunkt i kartlegging og skjøtselsanbefalinger fra mobiliseringsprosjektet, ble det etablert skjøtsels- og restaureringsprosjekter på de enkelte eiendommer. Disse prosjektene omfatter både gammel beitemark og slåttemark.

Alle de aktuelle arealene ligger på private eiendommer, og ingen av lokalitetene har vern etter lov. Skjøtsel av kulturlandskapet beror derfor på frivillig innsats fra den enkelte gårdbruker.

Prosjektet kjennetegnes av lokalt eierskap. Bygdelaget «Færbøgda i lag» har vært ansvarlig for mobiliseringsprosjektet, og den enkelte gårdbruker har vært ansvarlig for konkrete skjøtsels- og restaureringsprosjekter. Stjørdal kommune har gjennom alle faser spilt en rolle som pådriver og tilrettelegger. Kommunen har også bidratt med å målretta bruk av økonomiske virkemidler.

\section{Prosjektets mål for biologisk mangfold}

Målsettinga for prosjektet har vært å ta vare på det biologisk mangfold i Forradalens slåttenger og beitemarker gjennom skjøtsel og restaurering. 
Målsetting for mobiliseringsprosjektet:

- Økt kunnskap og interesse for kulturlandskapsverdiene (biologisk mangfold og kulturminner)

- Kulturlandskapsverdier som grunnlag for tiltak og aktiviteter, herunder ønske om å etablere flere tiltak som kan støttes økonomisk av tiltaksmidler i landbruket

\section{Målsetting for siste prosjektfase:}

- Etablering av skjøtsels- og restaureringstiltak for slåtteeng og beitemark på de enkelte gårdsbruk.

\section{Tiltak som er gjennomført}

- Kompetansheving er gjennomført gjennom kurs og «markdager» med demonstrasjoner i felt.

- Det er gjort kartlegging av verdifulle lokaliteter for biologisk mangfold i kulturlandskapet (slått- og beitemark). Kartlegging ble utført av Bioforsk, Kvithammar. Det ble gjort kartlegging av 37 områder, fordelt på 13 gårdsbruk. Det er gjort beskrivelse av flora og vegetasjon som inkluderer krysslisteregistreringer for alle lokaliteter. Foruten registreringer ble det gitt anbefalinger om skjøtsel. Det ble gitt tilbud om registrering til alle gårdbrukere.

- Det ble engasjert fotograf til å lage utstilling av bilder fra Forradalens kulturlandskap på butikken i bygdesenteret.

- Mobilisering av oppvekstsenteret (skole og barnehage) som har hatt prosjekt med beiterestaurering og beiting av geiter.

- I hovedsak basert på resultatet fra registreringsarbeidet, er det etablert rydding og skjøtsel på de enkelte eiendommer.

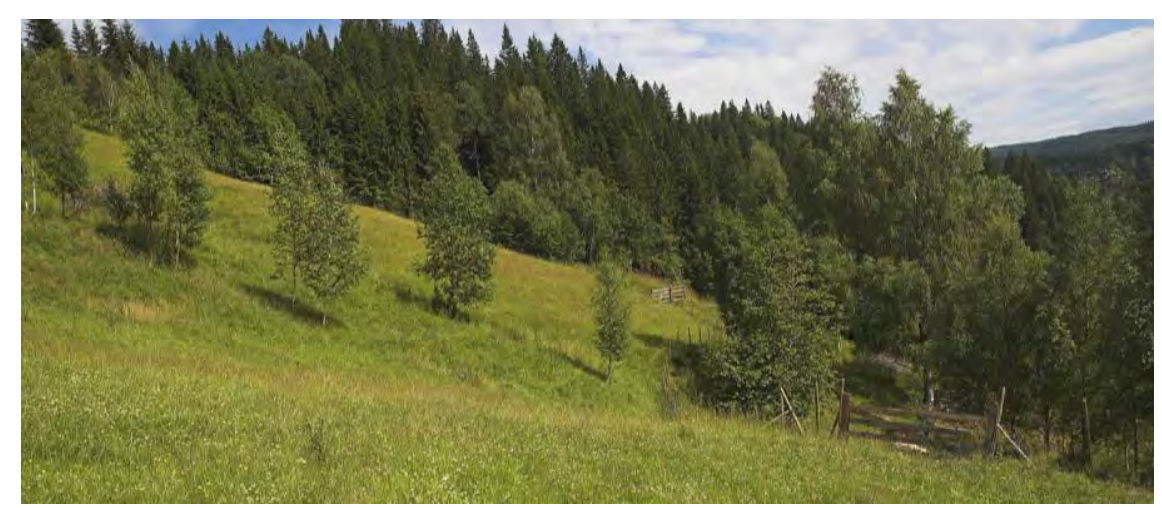

Fig. 64. Gammel beitemark har blitt restaurert ved at kratt har blitt fjerna, og det er satt $i$ gang beite.

Foto: Stjørdal kommune. 


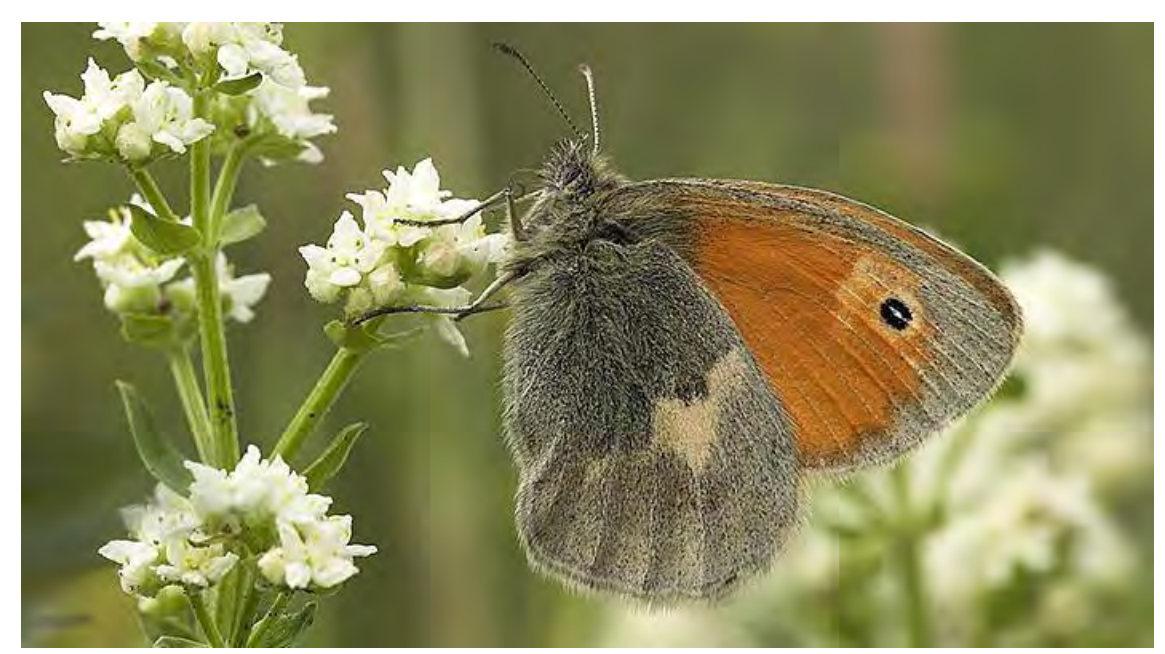

Fig. 65 Engringvinge (Coenonympha pamphilus) er en typisk art i engene.

Foto: Stjørdal kommune.

\section{Resultater som er oppnådd}

- Kartleggig av engvegetasjon har gitt betydelig økning av kunnskapen om biologiske verdier i Forradalens kulturlandskap. Dette har gitt et faglig grunnlag for forvaltning av området og etablering av skjøtselsog restaureringstiltak. Kartlegginga har dokumentert at Forradalen har en høg forekomst av artsrike slåtteenger og beitemarker, og at verdien ikke bare er knytta til de enkelte lokaliteter, men at de reprenterer en helhet der det er mulighet for spredning av arter mellom lokalitetene.

- Med utgangspunkt i kartlegging er det etablert skjøtsel/restaurering på i alt 17 områder. Det gjelder 5 områder med tradisjonelt slåttebruk samt restaurering av beitemark (rydding av krattskog og beite) på lokaliteter som var tilgrodd på til sammen 12 områder.

- Innafor landbruksnæringa er det etablert et faglig miljø som grunnlag for bevaring og videreutvikling av de biologiske kvalitetene i kulturlandskapet. Den skjøtsel som drives for bevaring av biologisk mangfold inngår som del av den ordinære jordbruksdrifta og er derfor ikke en museal aktivitet.

- Slåttedag er en ny aktivitet som legger vekt på formidling av verdiene $\mathrm{i}$ kulturlandskapet - både de biologiske og kulturhistoriske. Slåttedagen inngikk ikke i det opprinnelige prosjektet, men har vokst fram som en følge av dette. Slåttedagen ble arrangert første gang i 2008 og gjentatt i 2009. Slåttedagen har vært et vellykket arrangement som har nådd ut til et stort publikum. Det er beslutta å videreføre slåttedagen som heretter vil bli arrangert annet hvert år.

- Kulturlandskapsprosjektet i Forradal har synliggjort verdien av kulturlandskapet som ressurs for lokalsamfunnet, og gitt inspirasjon til ny aktivitet lokalt. Vi erfarer at prosjektet også har vakt interesse utenfor lokalmiljøet, og at det dermed har et potensial for å inspirere til innsats for bevaring av biologisk mangfold i kulturlandskapet andre steder. 


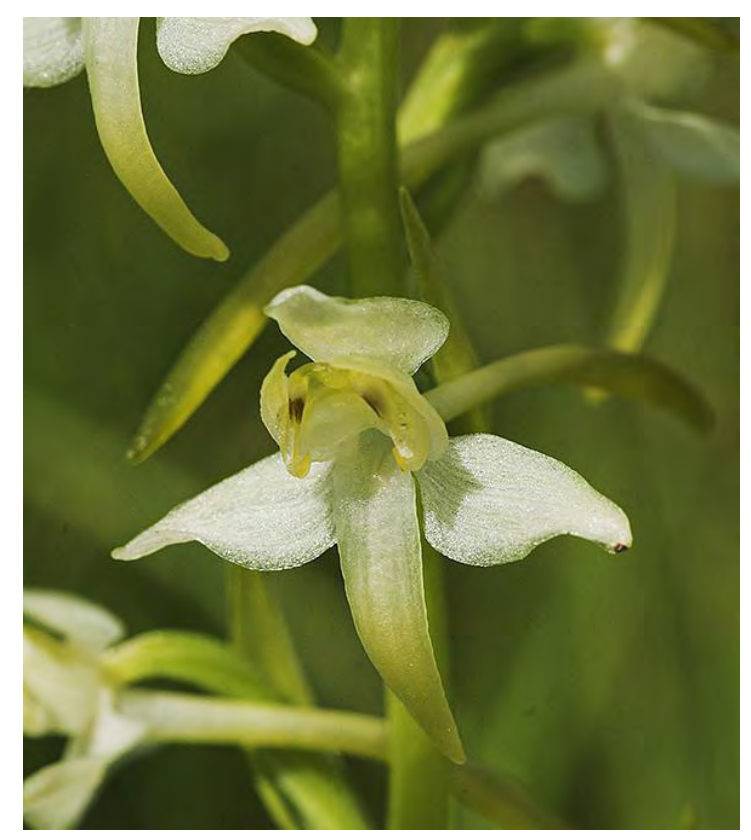

Fig. 66. Grov nattfiol (Platanthera montana) forekommer i flere av slåtteengene i Forradal. Foto: Stjørdal kommune.

\section{Erfaringer}

- Kulturlandskapsprosjektet i Forradalen har i stor grad vært bygd på lokalt eierskap og engasjement. Det har vært en avgjørende suksessfaktor for prosjektet.

- Skjøtselen av kulturlandskapet bygger på frivillighet og et personlig engasjement hos den enkelte gårdbruker. Derfor er det viktig at det finnes økonomiske virkemidler som er forutsigbare og kan stimulere til innsats $i$ et langsiktig perspektiv.

- For å lykkes ser vi at det er viktig med et godt samvirke mellom privat og offentlig engasjementet. God samhandling mellom kommunale myndigheter og gårdbrukere er nødvendig.

- For prosjektet har det vært av stor betydning at det er bygd på et solid faglig grunnlag med bruk av forskningskompetanse (Bioforsk, Kvithammar).

- For å skape et engasjement har det vært viktig å synliggjøre verdien av kulturlandskapet.

\section{Videre arbeid}

Skjøtselen på de enkelte eiendommene er godt etablert og blir ført videre. Slåttedagen vil fortsette som en aktivitet. Ut over dette er det så langt ikke planlagt nye aktiviteter. 


\subsection{Prosjekt 2. Regulering av vannmiljø og mulige tiltak i gamle elveløpet Halsøen, Langøra og Stjørdal havn}

- et plan og utredningsprosjekt der målet er å bevare de biologiske verdiene $i$ et særlig rikt naturområde med mange kryssende arealbruksinteresser og utviklingsplaner.

\section{Prosjektbeskrivelse}

Prosjektområdet ligger i tilknytning til Stjørdal sentrum. Det omfatter Stjørdalselvas gamle elveløp, utløpet av Gråelva og omkringliggende strandområder ut mot Trondheimsfjorden, bl.a. øya Langøra som er landfast gjennom rullebanen på Trondheim lufthavn, Værnes.

Området er sterkt påvirka av menneskelig virksomhet. Ved utbygging av rullebanen på Værnes flyplass i 1959 fikk Stjørdalselva nytt utløp ved at rullebanen ble lagt på fylling som stenger det gamle elveløpet. Ny trasé for Europavei 6, på vestsida av det gamle elveløpet, medfører utfylling i strandsonen. Deler av området i nord, Tangen, er utfylt for å gi plass for næringsvirksomhet. Småbåthavn ligger i utløpet av Gråelva og Stjørdal havn ligger på steinfylling. Langøra har vært brukt til militær øvingsvirksomhet.

Til tross for stor påvirkning av tunge tekniske inngrep, er området et av de viktigste områdene for biologisk mangfold i kommunen og har nasjonal verdi. Området er svært viktig for fugleliv der området har betydning først og fremst som overvintringsområde og rasteområde under rekk vår og høst. Arter som grågås og kortnebbgås, stokkender og vadere opptrer i stort anll. Oteren lever også i området. Langøra har stor betydning for virvelløse dyr, bl a.flere sjeldne biller og stor bestand av rødlistearten stor elvebreddedderkopp (Arctosa cinerea).

Spesielt har strandengene og sand-strendene på Langøra stor botanisk verdi.

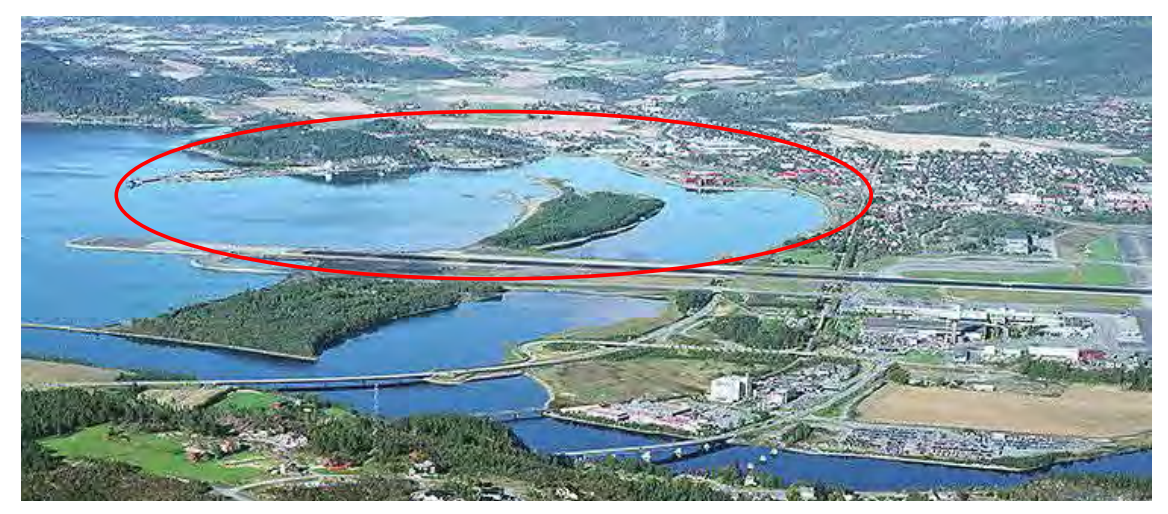

Fig. 67 Prosjektområdet omkring Stjørdalselvas gamle elveløp.

Foto: Stjørdal kommune. 
Det skjer omfattende sedimentering i det gamle elveløpet som på sikt vil redusere vannspeilet. Dette er ei utfordtringa for forvaltning av området både av hensyn til biologisk mangfold og for elva som landskapselement.

Det er knytta store utviklings- og utbyggingsinteresser til området, og det er ei målsetting å knytte området nærmere sammen med byens sentrum.

Alle fysiske utviklingsplaner gir utfordringer i forhold til biologisk mangfold:

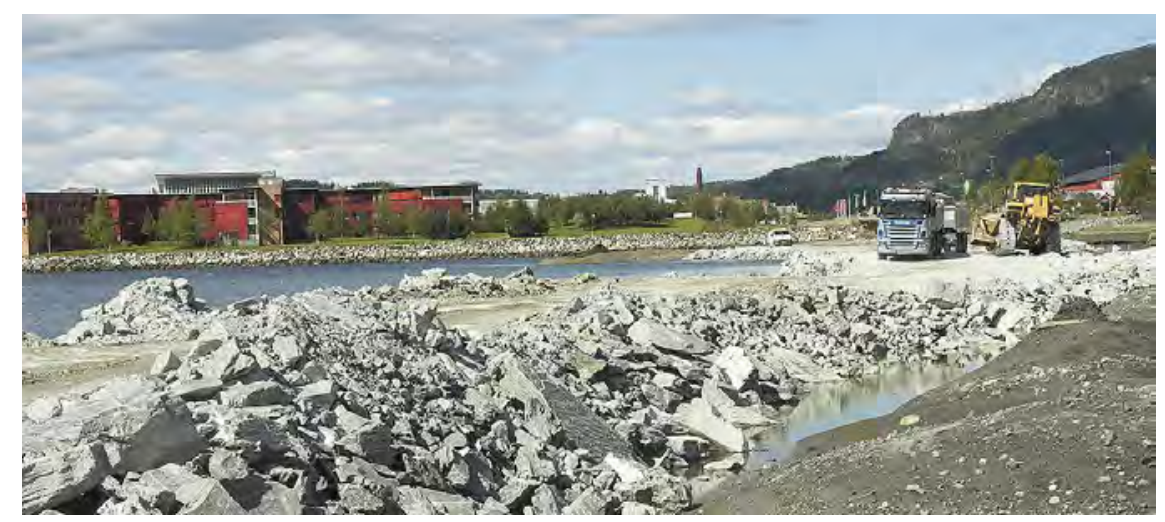

Fig. 68. Utbygging av vei er et av mange inngrep $i$ området.

Foto: Stjørdal kommune.

- Det er behov for utvidelse av småbåthavn som ligger i utløpet av Gråelva.

- En planlagt utvidelse av Stjørdal havn vil medføre betydelig utfylling som vil kunne påvirke strømningsforhold.

- Det er et ønske om å tiltrettelegge Langøra for friluftsliv med bruforbindelse. Økt ferdsel vil være konfliktfylt i forhold til biologisk mangfold, og det er nødvendig å få belyst om denne konflikten kan løses gjennom ferdselsrestriksjoner.

- Det er ønske å restaurere strandsonen og øke tilgjengelighet til sjø på eksisterende steinfylling på næringsområdet Tangen.

- Det er ønske om å vurdere effekten av kanal gjennom Langøra for vannutskifting og sedimentering i det gamle elveløpet.

- Det planer om gangvei fra Tangen til Havna og Storvika samt gangog sykkelvei langs Gråelva.

Store miljøverdier og mange kryssende arealbruksinteresser i området har gjort at det er ønskelig å behandle utfordringene i området i størst mulig bredde.

Dette har vært bakgrunnen for å etablere et prosjekt for å behandle utfordringene samla i utredning og plan.

Første trinn i prosessen var utarbeidelse av planprogram. Planprogrammet beskriver mulige tiltak og fastsetter de utredninger som skal gjøres i forhold til tiltak og interesser i området. Det har vært et mål at utredningene skal tilfredsstille utredningsbehovet for kommuneplan (overord- 


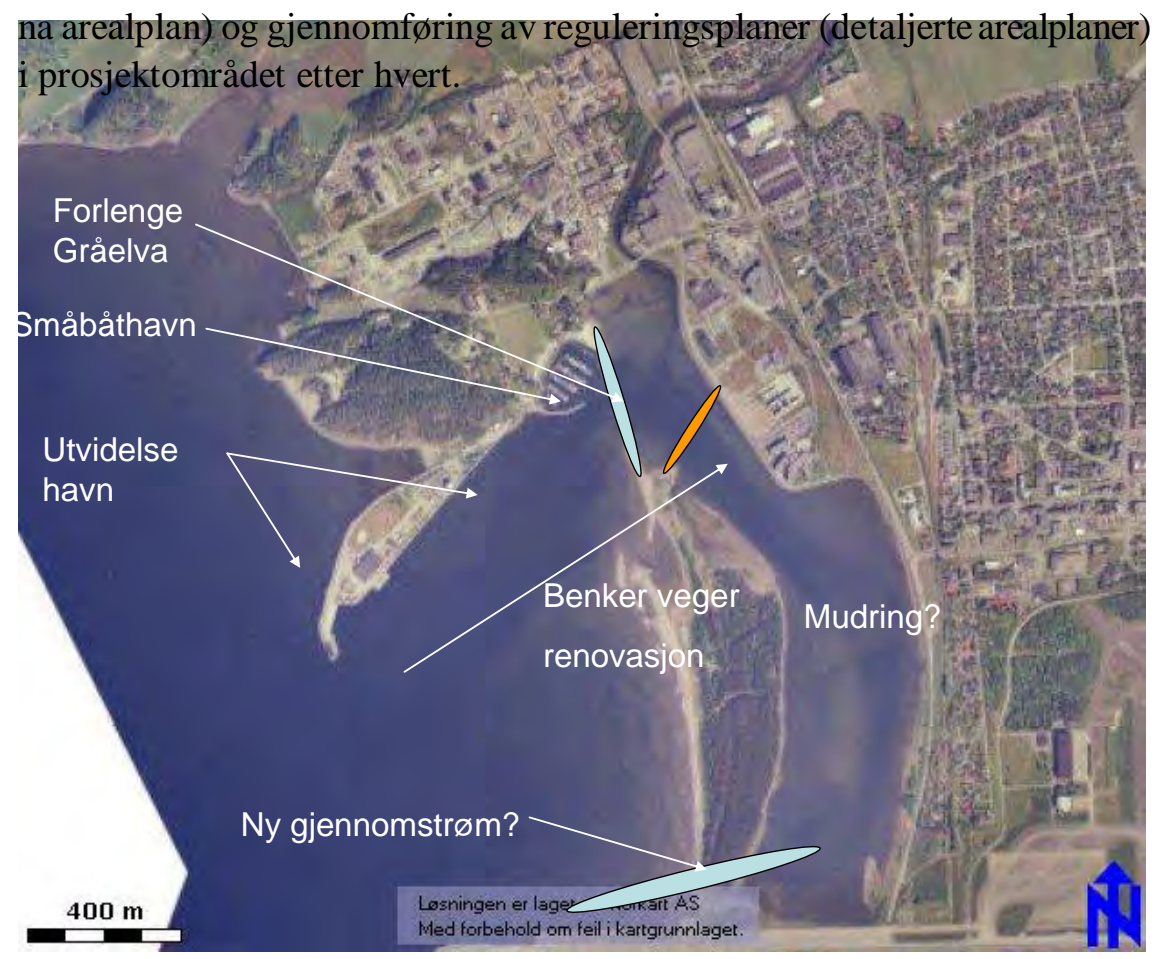

Fig. 69. Mulige tiltak i prosjektområdet.

Foto: Stjørdal kommune.

Stjørdal kommune er ansvarlig for arbeidet, men det har vært forutsatt $\varnothing$ konomisk og praktisk bistand fra tiltakshavere i utredningsområdet. Viktige aktører er bl a. Statens vegvesen, Trondheim havn (eier av havna), Avinor (flyplasseier), Forsvaret som grunneier på Langøra, Stjørdal småbåtforening m. fl.

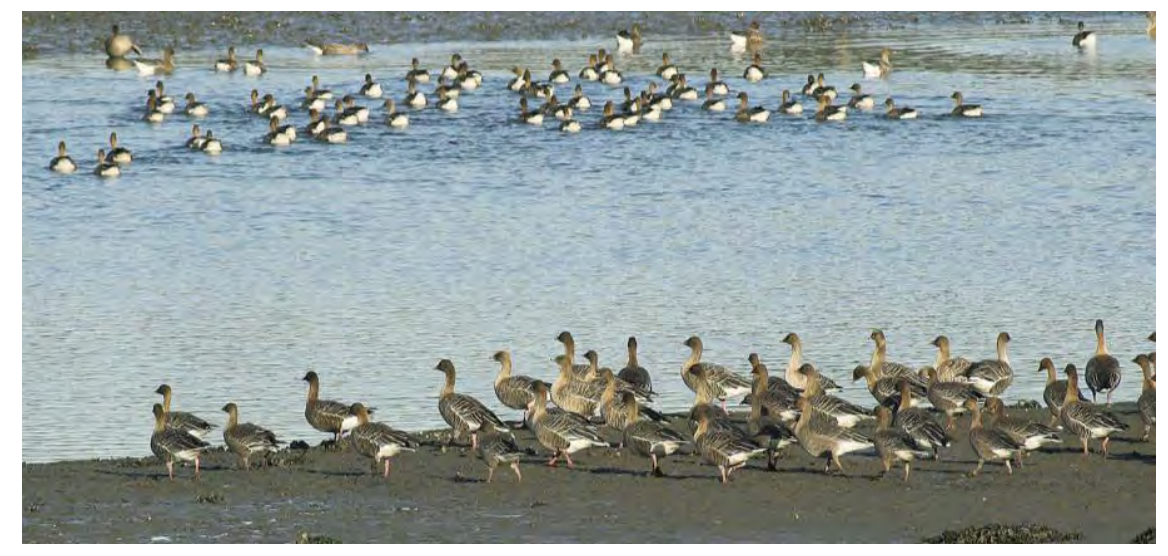

Fig. 70. Områdene omkring Stjфrdalselvas gamle elvelфp er viktige for mange arter, bl.a. kortnebbgås.

Foto: Stjørdal kommune. 


\section{Mål for biologisk mangfold}

Målet for prosjektet er finne muligheter for å bevare biologisk mangfold i et område med mange kryssende arealbruksinteresser gjennom plan og utredning. Fysiske tiltak ligger derfor utafor prosjektets ramme.

En viktig del av målsettinga er derfor å finne de problemstillingene som skal belyses med utgangspunkt i kjente arealbruksinteresser i området (planprogram).

Videre er det et mål å gjennomføre de nødvendige utredninger som grunnlag for planarbeid.

\section{Tiltak som er gjennomført}

- Det er vedtatt planprogram som fastsetter utredningsbehov for videre planarbeid.

- Reguleringsplan for utvidelse av småbåthavn er under arbeid.

- Reguleringsplan for området Tangen er vedtatt.

- Reguleringsplan for utvidelse av rullebanen utover i sjø er vedtatt.

- Reguleringsplan for ny motorveitrasé er vedtatt. Byggeprosjekt er påbegynt 2009.

- Strømningsanalyse for det gamle elveløp er utført.

- Hekkefuglundersøkelse på Langøra og oppdatert status for fuglelivet i prosjektområdet.

- Konsekvenser for fugleliv og marinbiologi ved utvidelse av flyplass er utført.

\section{Resultater som er oppnådd}

Planprogrammet er et resultat av et omfattende arbeid som beskriver tiltak og fastsetter de utredningene som skal gjøres for aktiviteter og interesser som finnes innafor planområdet. Gjennom planprogrammet har en vært i stand til å identifisere mulige konflikter med biologisk mangfold for de utbyggingstiltakene som er beskrevet. En bred høringsprosess har sikra at alle relevante interesser har fått mulighet til å delta.

Arbeidet med reguleringsplan for utvidelse av småbåthavn har gjort det klart at det siste av to planlagte byggetrinn ikke kan gjennomføres på grunn av konflikt med biologisk mangfold. Godkjenning av reguleringsplan for første byggetrinn vil kreve ytterligere utredning som bl a. gjelder konsekvenser for biologisk mangfold.

Det ble vedtatt reguleringsplan for forlengelse av rullebanen ved flyplassen ved utfylling i sjø. Konsekvensvurderinger for fugleliv og marinbiologi, tilsa en liten konflikt med biologisk mangfold ved utfyllinga.

Strømningsanalyse utført av SINTEF, Trondheim viser bl.a at nytt elveutløp i kanal gjennom Langøra i seg sjøl ikke vil gi vesentlig effekt på vannutskifting og sedimentering i det gamle elveleiet. Analysen tilsier at en kanal gjennom Langøra vil kunne ha positiv betydning for vannutskiftning og gi redusert sedimentering bare dersom det nåværende utløpet av Gråelva stenges ved å gjøre Langøra landfast i nord. 
Hekkefuglundersøkelser på Langøra bekrefter oppfatninga av at området har en relativt ordinær tetthet og artsforekomst. Langøras betydning for fuglelivet er ikke primært som hekkeområde.

I prosjektperioden har det framkommet planer og utredninger som har gitt avklaring på noen av de problemstillingene som er reist mht til biologisk mangfold. Vi må likevel erkjenne at vi ikke har nådd så langt som forutsatt innafor prosjektperioden.

\section{Erfaringer}

Arbeidet med å få vedtatt et planprogram som skal beskrive tiltak og utredninger, viste seg å være mer krevende enn forutsatt og har bidratt til å forsinke arbeidet i forhold til opprinnelig framdriftsplan

På grunn av knapphet på ressurser det vært vanskelig å gi prosjektet nødvendig prioritet fra kommunens side, noe som også har bidratt til å gi mindre framdrift enn forutsatt.

Det ligger en betydelig verdi i arbeidet med å få vedtatt et planprogram da dette i seg sjøl framtvinger en bevissthet om å se ulike arealbruksinteresser og mulige konsekvenser for biologisk mangfold i sammenheng. Dette er også av betydning når det, av ulike grunner, blir nødvendig å gjennomføre enkeltiltak før alle utredninger foreligger.

\section{Videre arbeid}

Prosjektet vil bli videreført $\mathrm{i}$ hht intensjonen med de utredninger som er fastsatt $\mathrm{i}$ planprogrammet, men med mindre framdrift enn opprinnelig forutsatt. En del av problemstillingene som er reist vil bli avklart gjennom arbeidet med rullering av kommuneplanen som skal vedtas i 2010.

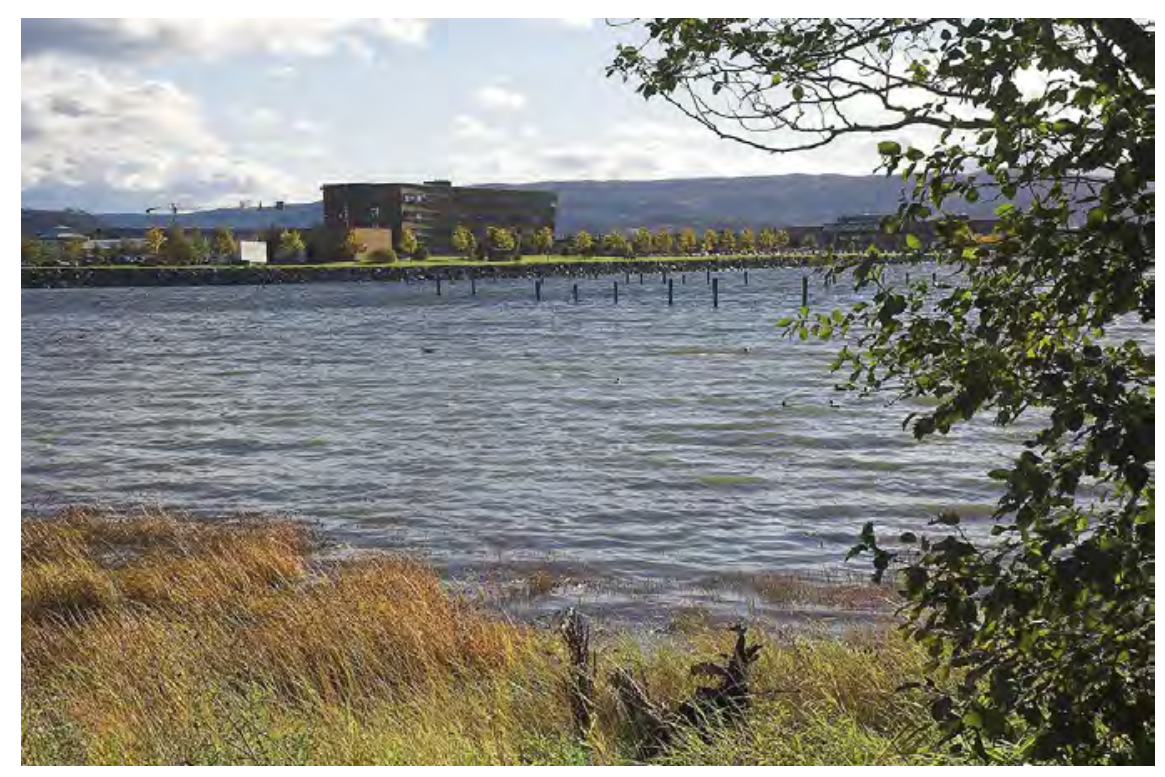

Fig. 71. Stjørdalselvas gamle elvelp - en naturperle ved bysenteret.

Foto: Stjørdal kommune. 


\section{Trondheim kommune}

Trondheim er det nasjonale kompetansesenter innen forskning og forvaltning av biologisk mangfold. Handlingsprogrammet for naturmiljøet i Trondheim ble enstemming vedtatt $i$ bystyret 1 . august 2006. Kommunen signerte Countdown 2010-erklæringa under åpninga av Trondheimskonferansen 29. oktober 2007.

\subsection{Prosjekt 1. Gjenåpning av Ilabekken - restaurering av biologisk mangfold i en urban bekk}

I Trondheim er bynære bekker blant de biologiske systemer som er mest påvirket og truet av menneskelig aktivitet. En av de mest påvirkede bekkene er Ilabekken, som har utløp i Trondheimsfjorden, vest for bykjernen. Ilabekken er del av et vassdragssystem på $10 \mathrm{~km} 2$ som strekker seg innover i Trondheim Bymark. Øvre del av vassdraget utgjør et viktig naturelement og turdrag for byens befolkning.

Den nederste delen av Ilabekken, en strekning på ca. $700 \mathrm{~m}$, har i løpet av de siste ca. hundre år vært lukket og lagt i rør; først nærmest fjorden omkring år 1910 og senere utvidet på 1960-tallet. Vannkvaliteten på denne strekningen har blitt merkbar dårligere de siste 20-30 årene med store tilførsler av urenset kloakk. Bekken har tapt sitt naturlige biologiske mangfold; blant annet har sjøørretbestanden (Salmo trutta L.) vært borte i over 100 år.

I 2005-2008 muliggjorde bygging av et større veiprosjekt, Nordre avlastningsveg for Trondheim sentrum, at bekken kunne gjenåpnes. Trondheim kommune utarbeidet en egen reguleringsplan, som foruten restaurering av bekken også inkluderte rekreasjonsområder, sti system og kunstnerisk utsmykking i området. En sentral målsetting var at bekken skulle gjenvinne sitt naturlige biologiske mangfold.

Anleggsarbeidene startet i 2005 og gjenåpning av bekken ble ferdig i juni 2008.

Miljøtiltaket har vært et samarbeidsprosjekt mellom Trondheim kommune og Statens Vegvesen. Kostnader ca. 10 mill. norske kroner. 


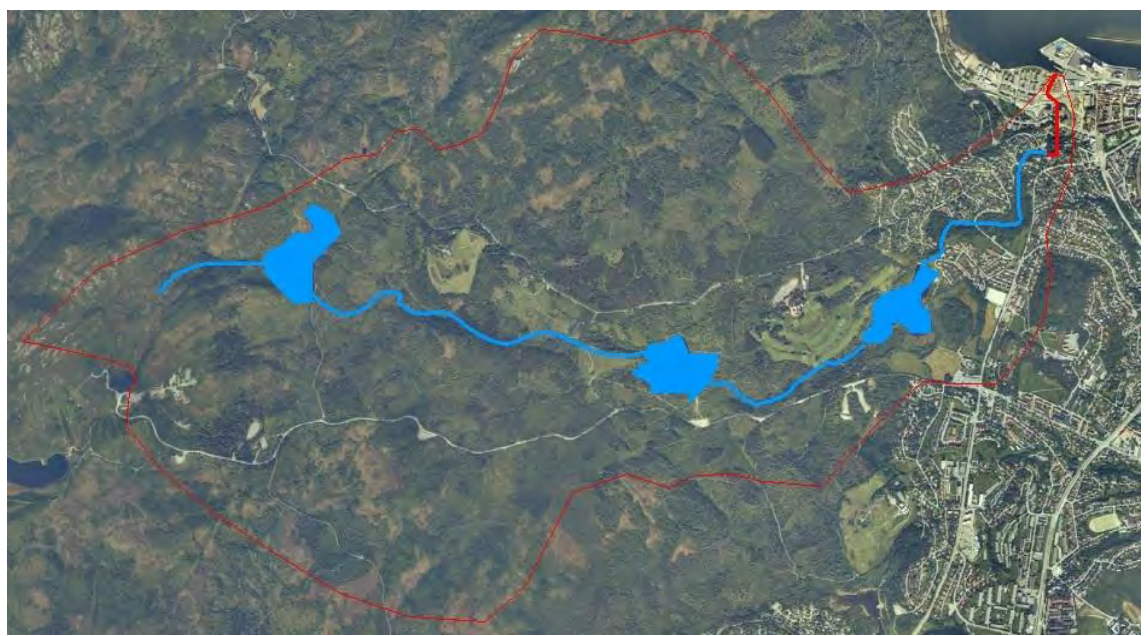

Fig. 72 Ilavassdraget. Nedre lukket del av bekken merket med rødt. Foto: Trondheim kommune.

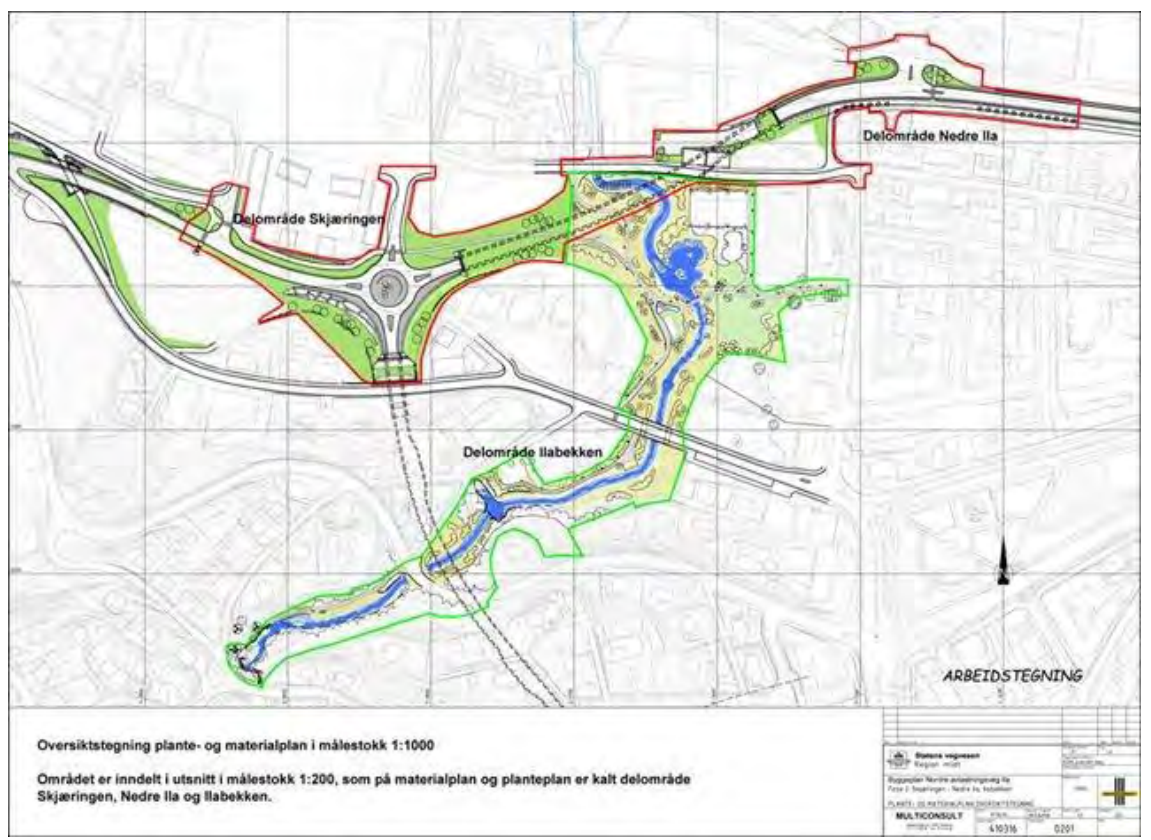

Fig. 73 Skisse for planutforming av Ilabekken: Gjenåpning av Ilabekken - restaurering av biologisk mangfold i en urban bekk.

\section{Prosjektets mål i forhold til biologisk mangfold}

- Oppnå stabil og god vannkvalitet $\mathrm{i}$ bekken tilsvarende naturlig bakgrunnsnivå.

- Oppnå stabil og god økologisk tilstand i og rundt bekken med forekomst av forurensningsfølsomme vannorganismer og vannfugler.

- Gjenskape bekken som sjøørretbekk med en stabil og selvreproduserende bestand. 


\section{Tiltak gjennomført}

Grovutforming av bekken ble gjennomført høsten $2005 \mathrm{og}$ fram til sommeren 2006. Samtidig ble kloakkpåslag sanert, og det nye bekkeløpet fikk sommeren 2006 vanntilførsel fra øvre deler av vassdraget.

Justeringer av bekkeløpet og biotoptilpasninger ble utført i 2007, og bekken fikk sin endelige utforming og vannløp i løpet av vinteren/våren 2008. Tiltaket omfattet ca. $700 \mathrm{~m}$ bekkestrekning.

I bekken er det lagt vekt på å sikre livsvilkår for sjøørret, med egnete gyteog oppvekstområder. Ilabekken har potensiale til å bli sjøørretproduserende opp til et naturlig vandringshinder i en foss, ca. $500 \mathrm{~m}$ opp fra utløp i fjorden. Ved foten av fossen er det anlagt en kulp, som skal sikre overlevelse av større fisk. Kulpen er en del av gammelt jernbaneanlegg.

Det er også lagt vekt på å skape stor variasjon av mikrohabitater i bekken slik at et mangfold av bunnlevende organismer og vannfugler kan finne livsvilkår.

Gjenåpning av bekken ble ferdigstilt i juni 2008. Det har i hele anleggsperioden 2005-2008 vært et tett samarbeid mellom byggherrene Trondheim kommune og Statens vegvesen for å følge opp og tilpasse de ulike faser av tiltakene. Øvrige medvirkende aktører som utførende entreprenør, ulike rådgivere på vann/avløp og landskap samt kunstnere har deltatt både i utarbeidelse av planer for området, byggeoppfølging og utforming av bekkeløpet.

Å sikre tilstrekkelig vannføring i bekken gjennom hele året har vært oppfattet som en utfordring ettersom vann i bekken i hovedsak er avhengig av overløpsvann fra oppdemte vann i øvre del av vassdraget. Lengre tørrværsperioder kan derfor resultere i kritisk lavt vann nivå i bekken. Dette problemet ble teknisk løst høsten 2009, og automatisk vannmåler er nå installert slik at tilfredsstillende vannføring i Ilabekken sikres gjennom hele året. 

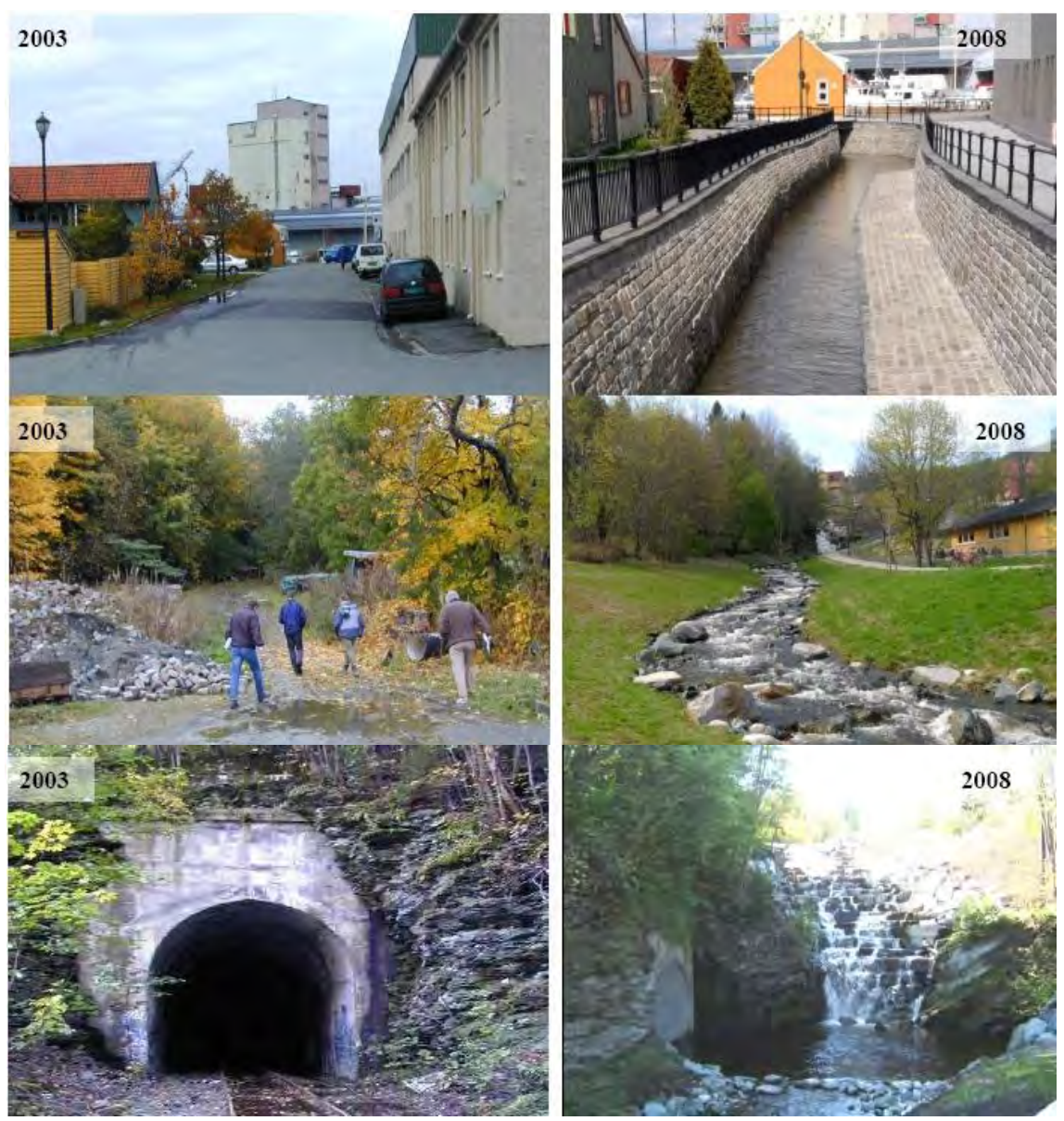

Fig. 74. Nedre, midtre og øvre del av Ilabekken før og etter tiltak.

Foto: Trondheim kommune.

Tiltakene er fulgt opp med følgende indikatorer og måleparametere:

Vannkvalitetsovervåking. Trondheim kommune har god oversikt over vannkvaliteten i den lukkede delen av bekken fra år 2000. Måleparametere er innhold av fosfor og tarmbakterier, som er gode indikatorer på kloakktilførsler. Denne overvåkingen er videreført i den nye åpne bekken.

Bunndyrundersøkelser. Måleprogram ble igangsatt fra 2007 for å vurdere rekolonisering av bunndyr og forekomst av forurensningsfølsomme arter.

Ungfiskundersøkelser. Måleprogram ble igangsatt fra 2007 for å vurdere reetablering av sjøørret og eventuelt avbøtende tiltak for å fremme bestanden.

\section{Resultater}

Vannkvalitetsovervåkingen viser at målet om god og stabil vannkvalitet ble oppnådd umiddelbart etter at kloakkpåslipp ble sanert fra høsten 2006. Innholdet av fosfor og tarmbakterier ligger nå omkring et forventet bakgrunnsnivå for tilsvarende vassdrag i regionen. 
God vannkvalitet fra høsten 2006 og habitat tilpasninger i bekken sommeren 2007 har gitt grunnlaget for at bekken kan gjenvinne sitt naturlige biologiske mangfold.

Bunndyrundersøkelser høsten 2007 bekreftet at rekolonisering av forurensingfølsomme arter var i gang. Det har videre skjedd en merkbar bedring i tilstanden for bunndyrsamfunnet fra 2007 til 2008. Forurensningstolerante arter innen EPT (Ephemeroptera, Plecoptera og Trichoptera) utgjør en stor andel av bunndyrsamfunnet. I 2008 ble 23 taxa EPT påvist, noe som er et høyt antall. Samme tilstand ble også påvist i 2009. Den gjenåpnede bekken karakteriseres nå av et robust og artsrikt bunndyrsamfunn med høy produksjon. Målet om god økologisk tilstand for bunndyrsamfunnet er oppnådd.

Høsten 2007 ble det påvist ungfisk av ørret på den gjenåpnede bekkestrekningen. Tetthetene var lave $(<1$ ind. per $100 \mathrm{~m} 2)$. Ørreten stammet fra rekolonisering fra ovenfor liggende, uberørte deler av bekken, og var ikke et resultat av egenproduksjon.

Fiskeregistreringene i 2008 viste imidlertid at gyting og egenproduksjon av sjøørret nå var i gang. Årsyngel ble påvist på hele strekningen og tettheten var god på typiske yngelhabitater (60 ind. per $100 \mathrm{~m} 2$ ). Middeltetthet avårsyngel på den gjenåpnede strekningen var nær 30 ind. per $100 \mathrm{~m} 2$ (Fig. 5). Gytemoden sjøørret ble fanget i nedre del av bekken i oktober 2008.

Registreringer i mai 2009 viste at det har vært god vinteroverlevelse av ungfisk av sjøørret født våren 2008 ..

Høsten 2009 ble tilsvarende tetthet av årsyngel av sjøørret påvist som i 2008. Et klart høyere innslag av ettåringer (1+) av sjøørret i 2009 viser at hovedandelen av ungfisk nå stammer fra produksjon av anadrom fisk og ikke fra nedvandring av stasjonær fisk fra øvre del av vassdraget. Det er derfor et godt håp om at bekken vil gjenvinne en livskraftig sjøørretbestand i de nærmeste årene.

Vi er også sikre på at laks har gytt i bekken i 2008. Høsten 2009 ble ett individ av årsyngel av laks påvist.

Vannfugler er tilbake i området. Norges nasjonalfugl fosskallen (Cinclus cinlus) er en hyppig gjest i bekken.

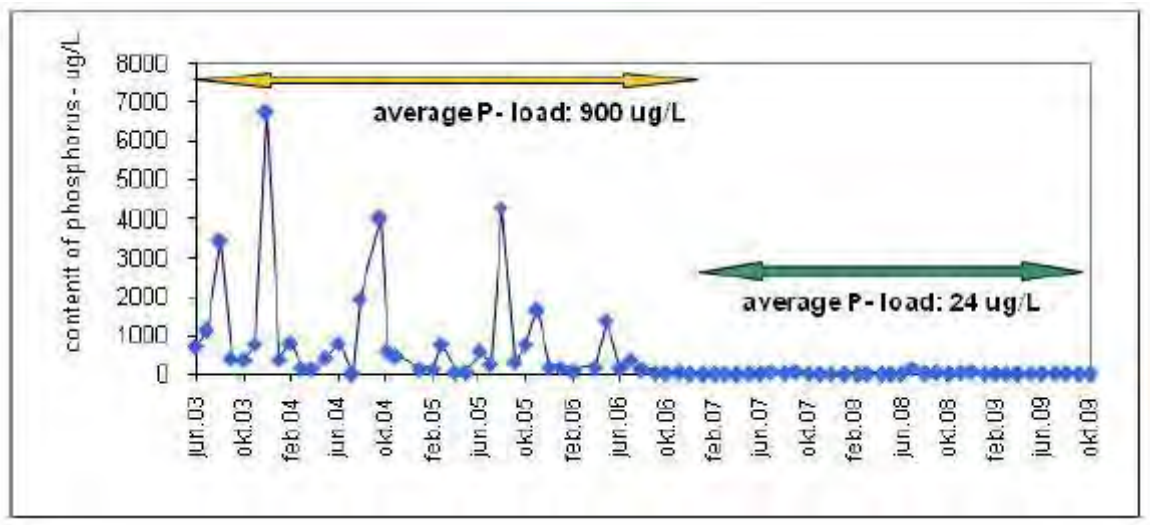

Fig. 75 Målet om god og stabil vannkvalitet er oppnådd. 


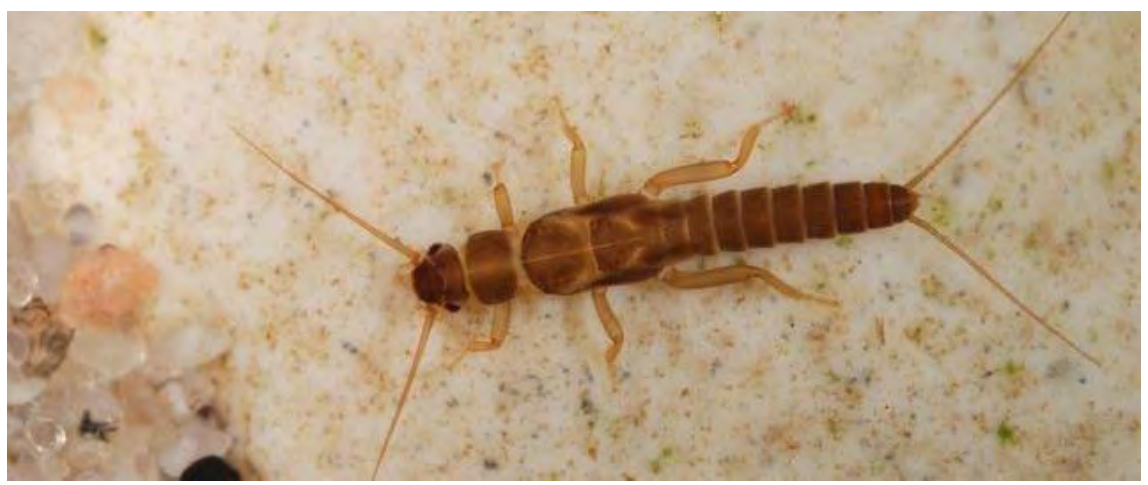

Fig. 76 Målet om et robust og artsrikt bunndyrsamfunn med høy produksjon er oppnådd. Steinfluen Leuctra hippopus er eksempel på en forurensningsfølsom art som er tilbake. Foto: Trondheim kommune.

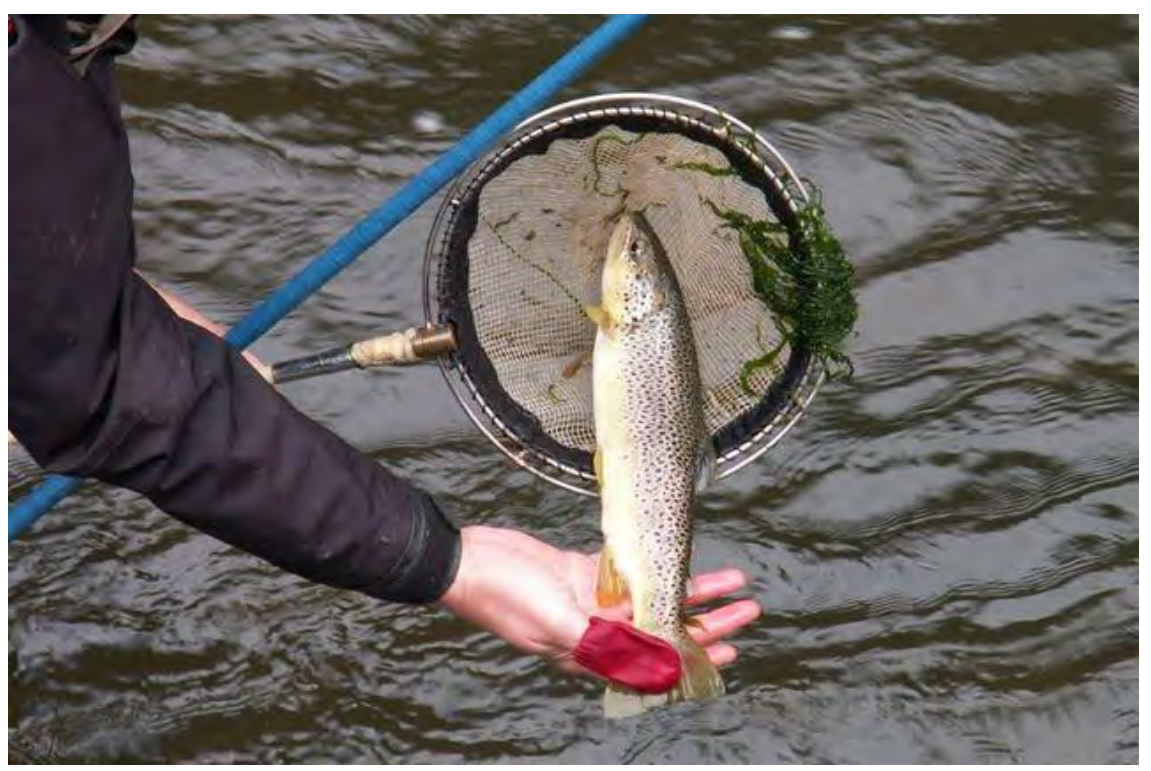

Fig. 77 Sjøørreten er tilbake og egenproduksjonen er i gang.

Foto: Trondheim kommune.

\section{Videre oppfølging}

Årlig overvåking av miljøindikatorene skal gjennomføres dvs. i forhold til vannkvalitet, bunndyr og fisk.

Ulike habitat-tilpasninger vil vurderes etter hvert som vi høster erfaring fra prosjektet.

\section{Erfaringer}

Prosjektet har på kort tid lyktes med å restaurere og gjenvinne det biologiske mangfoldet i den urbane del av Ilabekken.

Målene i forhold til vannkvalitet og økologisk tilstand for vannlevende organismer er oppnådd. Vannfugl er kommet tilbake.

Sjøørrret er kommet tilbake og egenproduksjon er i gang. 
Prosjektet har også lyktes med å skape et attraktivt og populært byrom samtidig som det er tilrettelagt for stisystem som forbinder den urbane del av vassdraget med øvre deler inn i markaområdene. Suksessfaktorer er i første rekke at miljøtiltaket har vært politisk forankret i Trondheim kommune og at kommunen selv er dominerende eier av arealene. En utløsende faktor har vært at kommunens planleggere tidlig i planprosessen med veiprosjektet, så gjenåpning av bekken som et mulig alternativ når gammel bekkekulvert skulle krysses. Det har videre vært politisk vilje til å investere i god vannkvalitet og inngå nært samarbeid med finanskraftig tiltakshaver, Statens vegvesen. Kommunen og Statens vegvesen har i felleskap funnet gode løsninger som sikrer ny og omfattende veisystem rundt Trondheim sentrum, samtidig som området i Iladalen er revitalisert der "gjenskaping av natur" er tillagt stor vekt. Fastsetting av en egen reguleringsplan for området har vært avgjørende. Lokalbefolkningen er hørt og blitt lyttet til. Planleggingsfasen har vært omfattende og flere aktører har medvirket til utforming av bekken og området forøvrig. Ulike tilpasninger under tiltaksperioden har vært nødvendig og aktiv dialog mellom aktørene har medvirket til gode løsninger. Biologisk kompetanse i kommunen har vært viktig for å vurdere ulike biotoptiltak og evaluere/overvåke tilstandsutvikling. Dette har også utløst et konstruktivt samarbeid mot forskningsmiljøer i byen.

\section{Loerdom av prosjekt}

- Åse alternative muligheter i startfasen av større vei- og anleggsprosjekter kan utløse interesse for å inkludere miljøtiltak.

- Politisk forankring i kommunen er avgjørende for å lykkes med et så omfattende miljøprosjekt som Ilabekken.

- Arealer må være tilgjengelige. Det er avgjort en fordel om kommunen eier arealene selv, eller er dominerende eier.

- God planlegging og åpen/konstruktiv dialog mellom kommunen og andre samfunnsektorer, lokal befolkning og brukergrupper sikrer gode løsninger og skaper "eierforhold" til prosjektet.

- Den samfunnsmessige gevinsten av å restaurere/gjennvinne natur må synliggjøres.

- God kompetanse og engasjement i kommunen gir et godt utgangspunkt for å utvikle samarbeidsrelasjoner.

\subsection{Prosjekt 2. Forvaltning av kulturlandskapet på Lian - Solem - skjøtsel og restaurering for å ivareta biologisk mangfold}

Trondheim kommune eier både gammelt og verdifullt kulturlandskap i markaområdene på vestsiden av byen og det har vært dyrking og beite i over 1000 år. Flere viktige arealer med historisk, landskapmessig og biologisk mangfold verdi er nå truet av gjengroing. Lian-Solem området er det største 
(25 ha) og et av de viktigste områdene å ta vare på. Området blir også mye brukt til friluftsliv, både sommer og vinter. På Lian-Solem opphørte ordinær gårdsdrift på slutten av 1930-tallet. Seinere ble området beitet av hest, kyr og sau fram til ca. 1970. Flybilder fra 1947, 1962/1963, 1978 og 1993 viser at gjengroingen har akselerert etter hvert som driften av jordbruksarealene gradvis ble redusert. Begrenset skjøtsel startet fra midten av 1990-tallet. Deler av området ble da beitet av hest i regi av en beboerforening i området, Lian vel. Fra år 2000 har den sørlige delen av området blitt gjerdet inn og brukt som beite for kjøttfe, hest og utegangersau. Høyt botanisk artsmangfold ble registrert i området i 2001; 149 registrerte karplanter, med blant annet flere rødlistede arter og store forekomster av orkideer (bl.a. grov nattfiol Platanthera montana). For å stanse tap av biologisk mangfold var behovet for omfattende og planmessig skjøtsel i området åpenbar. Trondheim kommune startet et skjøtselplanarbeid i området fra 2005. Avtaler ble inngått med beboerforening om bruk av bufe i området. I forbindelse med 2010-målet om å stanse tap av biologisk mangfold, ble det fra 2008 startet et mer målrettet skjøtselsplanarbeid med faglig oppfølging innenfor et areal på 192 daa. Samarbeidspartnere er Trondheim kommune, lokal beboerforening (Lian vel) og universitetet (NTNU).

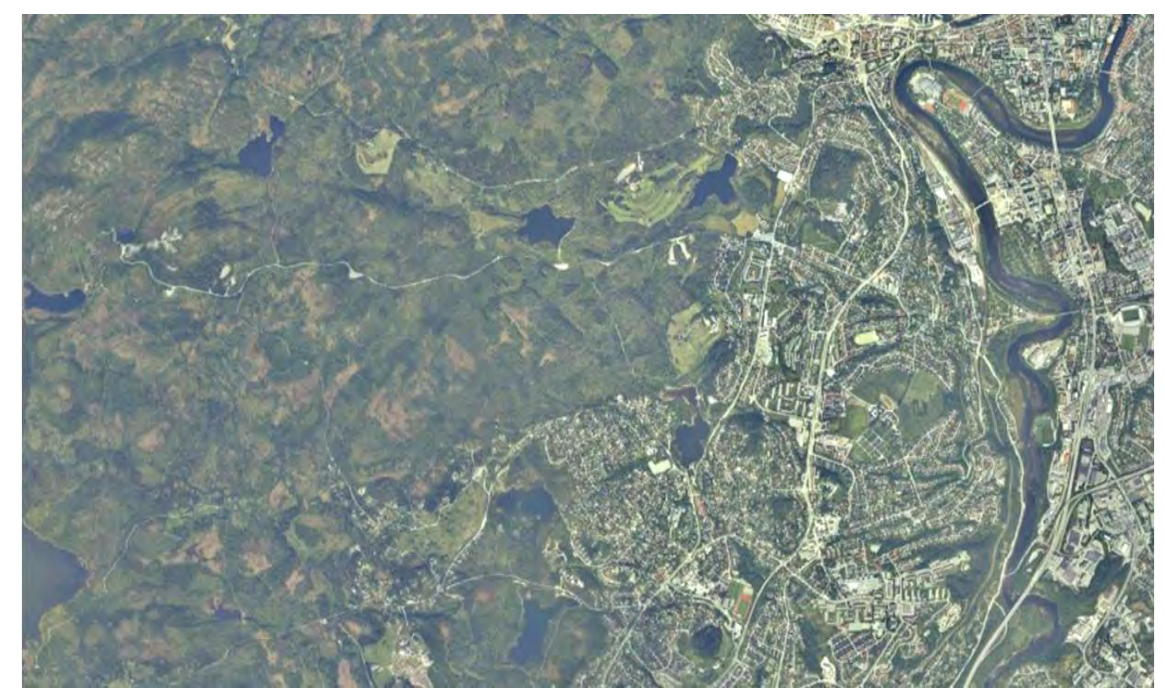

Fig. 78 Byncert og historisk kulturlandskap med høyt biologisk mangfold på Lian-Solem er truet av gjengroing.

Foto: Trondheim kommune.

\subsection{Prosjekt 3. Sårbare viltarter i Trondheim bymark - skjøtsel og restaurering for å ivareta biologisk mangfold}

Trondheim er en viltrik kommune og flere sårbare arter er knyttet til det ca. $85 \mathrm{~km} 2$ store utmarksområdet på vest og sørsida av byen, Trondheim Bymark. Det har blitt drevet tradisjonell hogstavvikling i mange år i området, og viltartenes leveområder er nå truet. Fragmentering og mangel på sam- 
menhengende områder gammel skog på grunn av hogst er den mest kritiske faktor. En annen risikofaktor er forstyrrelser fra et stort ferdselstrykk gjennom tilrettelegging av stier og løyper. I forbindelse med 2010-målet om å stanse tap av biologisk mangfold, ble det fra 2006/2007 startet en målrettet og langsiktig plan for å bevare biologisk mangfold for sentrale deler av Trondheim Bymark. Samarbeidspartnere er Trondheim kommune, universitetet (NTNU), Statsskog og lokale grunneiere.
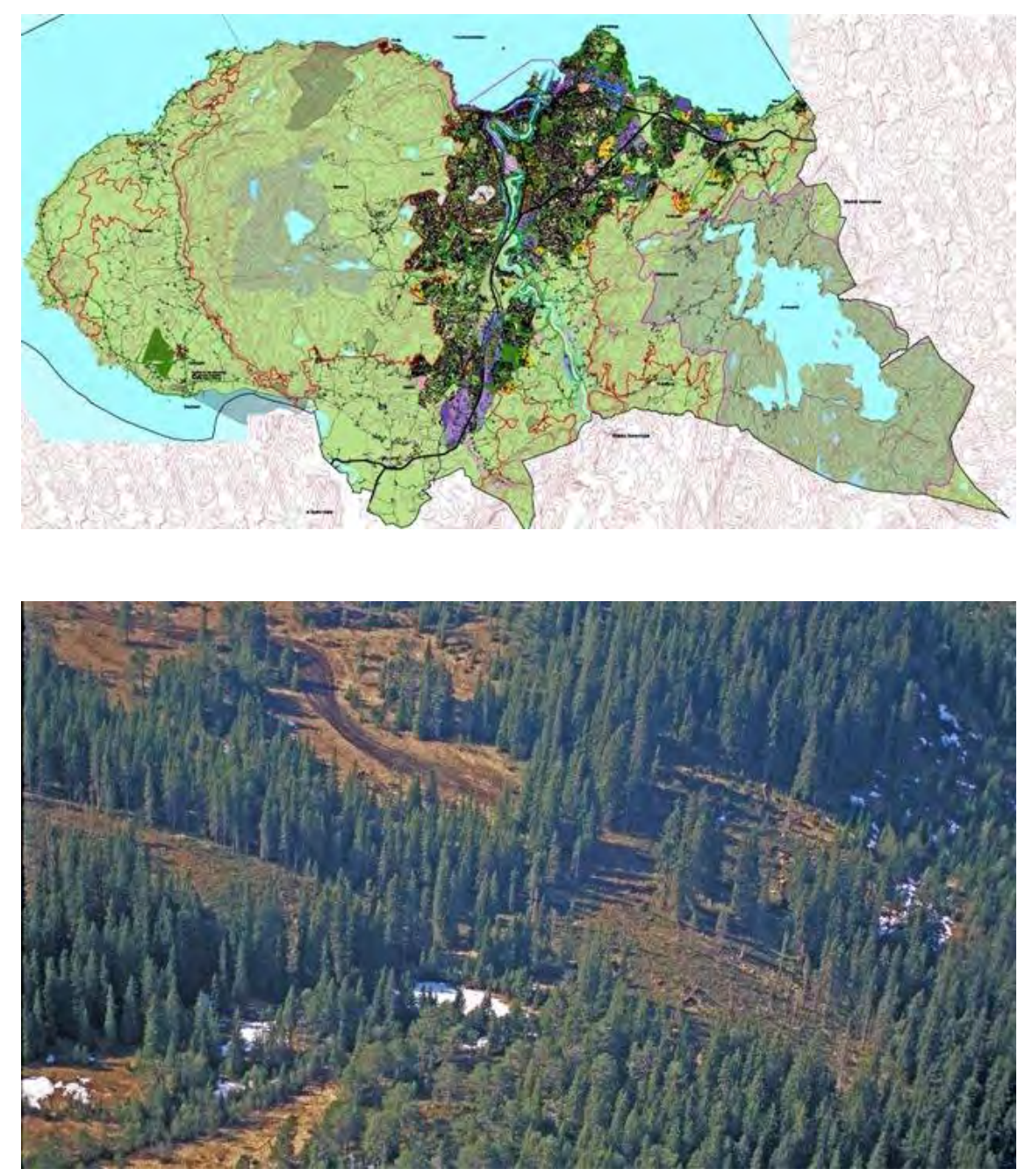

Fig.84 Leveområdene til sårbare viltarter $i$ Trondheim Bymark er truet. Fragmentering av gammelskogen er en kritisk faktor.

Foto: Trondheim kommune.

Innsamling av biologisk data har vært en prioritert oppgave i perioden 20062009. Vi har brukt storfugl (Tetrao urogallus) (Fig.85) som indikator for å angi tilstanden for livsvilkårene til sårbare viltarter. Storfuglen er avhengig av ulike habitater gjennom året, og mange viltarter er knyttet til disse habitatene. I tillegg har vi god kunnskap om storfuglens biologi og trusselfaktorer. Kjerneområdet for storfuglen i Trondheim Bymark er ca. 13 ha, avgrenset til om- 
rådet Bjørkåsen. Dette området antas å være den viktigste rekrutteringskilden til storfuglbestanden for øvrig i Trondheim Bymark. Antall tiur på leiken i Bjørkåsen antas normalt å være mellom 10 og 12. Etter år 2000 har antall fugl blitt redusert (Fig. 86). Det ble gjennomført en sårbarhetsanalyse i Bjørkåsen i 2006, som viste at vi nå nærmer oss en kritisk grense for overlevelse av storfuglbestandene. Hovedårsaken er økende hogstaktivitet i området. Bryter storfuglbestanden sammen kan viktig biologisk mangfold gå tapt i Trondheim Bymark. For å stanse tap av biologisk mangfold kan derfor overvåkingsdata av storfugl gi oss et godt grunnlag for å evaluere bestandsutvikling av storfugl og verifisering av aktuelle skjøtselstiltak på Bjørkåsen og markaområdene for øvrig.

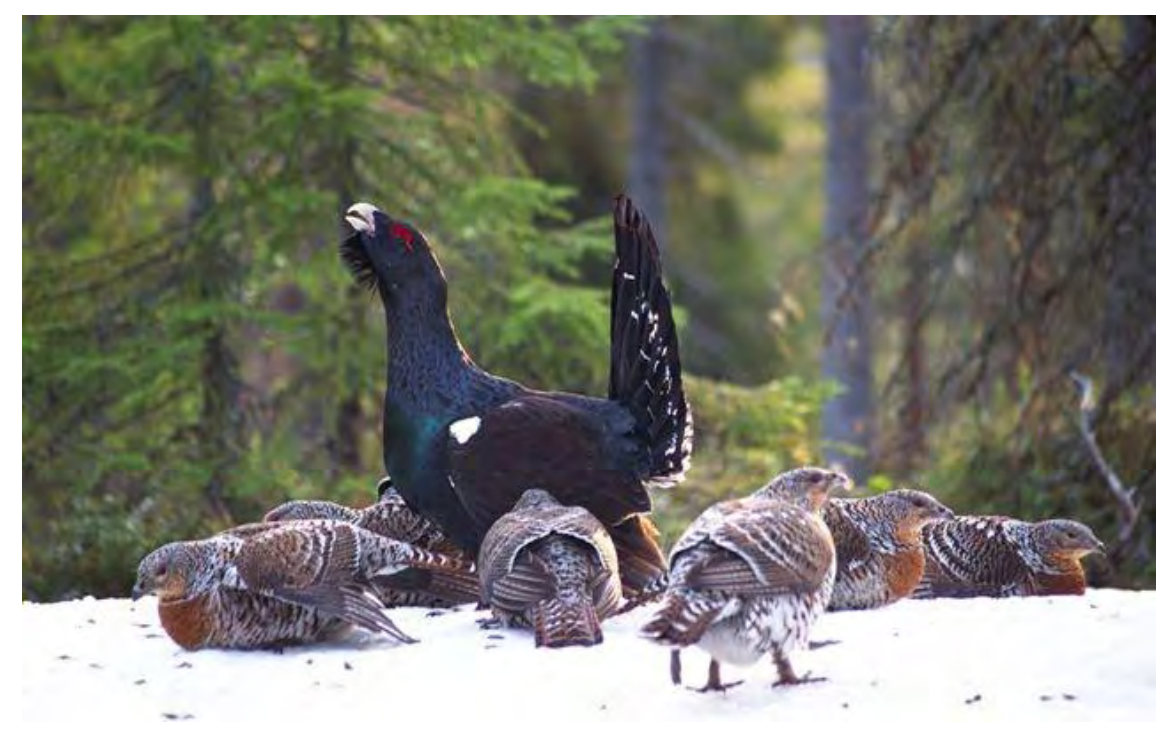

Fig. 85 Storfuglen er en egnet indikator for livsvilkår for sårbare viltarter $i$ skoglandskapet $i$ Trondheim Bymark.

Foto: Trondheim kommune.

\section{Prosjektets mål i forhold til biologisk mangfold}

Oppnå en skogtilstand som ivaretar livsmiljøet for storfugl og andre sårbare viltarter.

Unngå forstyrrelser fra et stort ferdselstrykk ved planmessig tilrettelegging av stier og løyper.

Ivareta folks muligheter til å oppleve kontakt med lokale rike viltbestander.

\section{Tiltak gjennomført}

All hogst i Bjørkåsen området ble i dialog med den statlige grunneier, Statsskog, stanset fra 2007.

Trondheim kommune har i 2009 utarbeidet et forslag til helhetlig forvaltningsplan for skog innenfor kommunen. Endelig plan forventes ferdig i 2010. Forvaltningsplanen tar opp i seg tømmerproduksjon, bevaring av bio- 
logisk mangfold, friluftsliv og rekreasjon som et samlet hele. Planen vil være veiledende for skogeierne slik at bl.a hensynet til leveområdene til sårbare viltarter vektlegges i daglig skogsdrift.

Trondheim kommune har i 2006 politisk vedtatt en handlingsplan for friluftslivet i markaområdene, som forutsetter at sti- og løype traseer ikke blir lagt til sårbare leveområder for viltarter.

Systematisk tellinger av storfugl og faglige vurderinger av bestandsutvikling og trusselbildet er foretatt i 2008 og 2009 gjennom et samarbeid mellom Trondheim kommune og fagekspertise fra universitetet.

\section{Resultater oppnådd}

Storfuglregistreringer 2008 og 2009 indikerer at antall tiurer på leiken synes å ha stabilisert seg på 6-7 tiurer (og et ukjent antall røyer) etter at de siste hogstinngrepene ble gjennomført i 2006/07. Leiken har flyttet seg en god del i løpet av de siste 10-15 årene. Vi er usikker på om dette har direkte sammenheng med hogst eller er et utslag av naturlig dominans forhold mellom tiurer. 


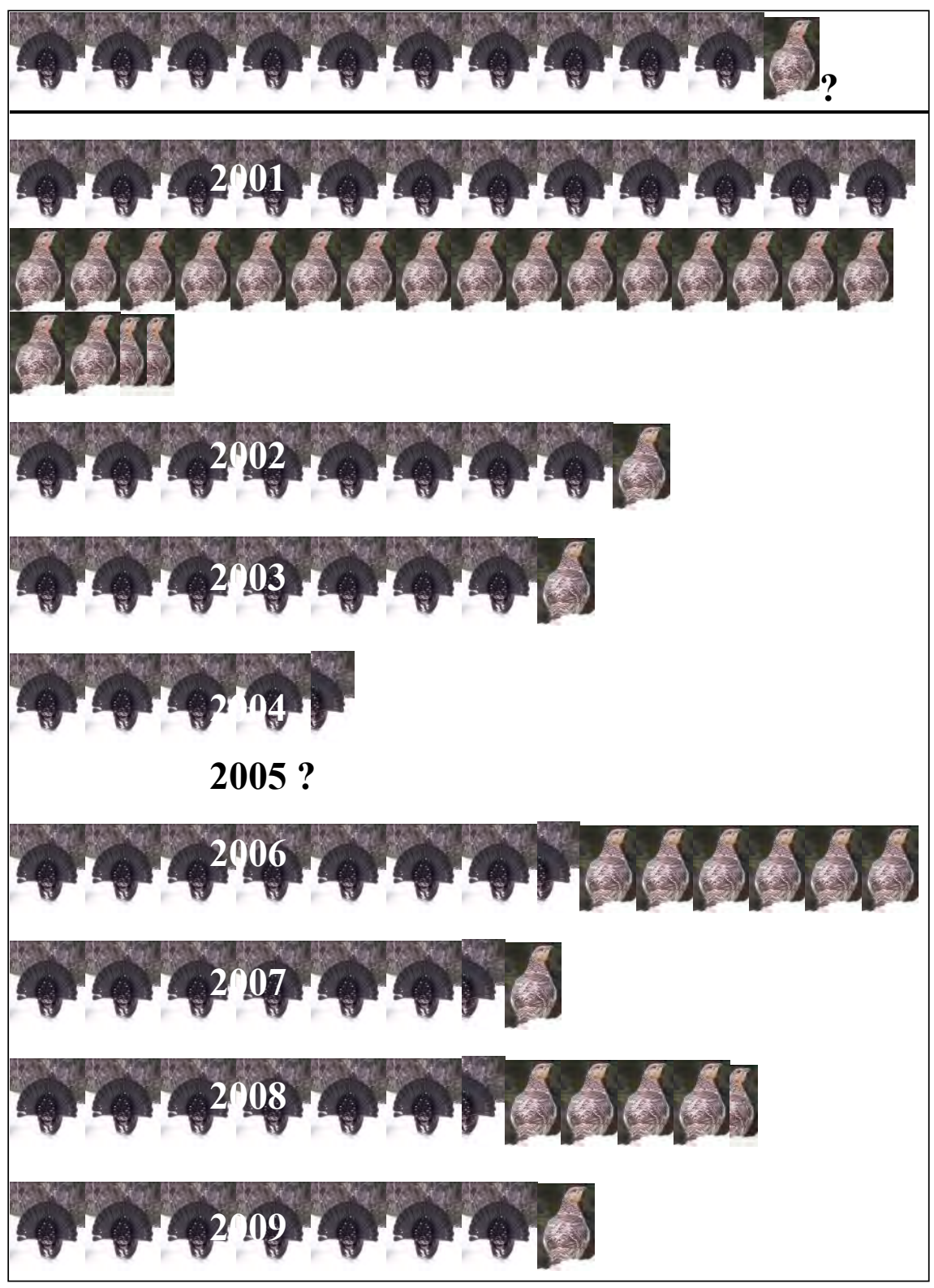

Fig.86 Maksimalt antall tiurer og røyer som er blitt registrert på leiken i Bjørkåsen etter år 2000. Det foreligger ingen kjente data fra 2005.

Utviklingen for Bjørkåsenleiken vurderes særlig på bakgrunn av 2009 registreringene å være rimelig god. Generelt har 2009 representert et bunnår for storfuglbestandene i hele landsdelen. Dette gir grunnlag for forhåpninger om at denne leiken vil kunne fungere som kildeleik for Trondheim Bymark også i framtida. Dette under den forutsetning at nærområdene, inklusive potensiell dagområder for storfuglen, blir forvaltet slik det nå legges opp til. Sårbare viltarter i Trondheim Bymark - skjøtsel og restaurering av biologisk mangfold 
En annen risikofaktor for leiken er forstyrrelse fra folk, men vi fant ikke spor som tydet på at dette har vært et problem under den mest intense spilltiden i 2009. Vanskelig tilgang på denne årstiden, på grunn av lite barmark og mye råtten snø innenfor det aktuelle terrengavsnittet, er nok den vesentligste faktoren som bremser folks utfartstrang på denne årstiden. Det er likevel viktig at det fortsatt er en så liten tilrettelegging av ferdselen i dette området som mulig.

\section{Videre oppfølging}

Det legges opp til å følge årlig utviklingen av storfuglbestanden på Bjørkåsen og andre områder.

Det vil etter hvert legges til rette for tilpasset skjøtsel av skog og tilrettelegging av friluftsliv. Ungskogen som vokser opp skal skjøttes for å skape gode betingelser for storfugl. Dette skal oppnås ved at ungskogen avstandsreguleres slik at det gis muligheter for nyforyngelse, dypere kroner og sjiktning, og tilpasse arealer med nok lys for å fremme blåbærlyng. Innen ungskogbestandene settes det igjen mindre grupper av løvholt som får gå hele sitt naturlige suksesjonsforløp. For å unngå unødig forstyrrelser i kjerneområdene for storfuglen skal det ikke tilrettelegges med stier og løyper.

Det tas sikte på å studere nærmere sammenhengen mellom forkomstene av storfugl og andre fuglearter, samt mulige sammenhenger mellom disse forekomstene og den nye skogforvaltningsplanen.

Det tas sikte på å gi informasjon til private skogeiere for å motivere til å ta hensyn til biologisk mangfold i den daglige drift.

\section{Erfaringer}

Trondheim kommune er en viltrik kommune, men samtidig er trusselbildet blitt betydelig forsterket de siste 10-20 årene som følge av byutvikling. For å ivareta sårbare viltarter har vi sett nødvendigheten av å ha god kunnskap både om artenes leveområder og trusselfaktorer. Erfaringene fra dette prosjektet viser at et godt kunnskapsgrunnlag har vært avgjørende for igangsetting. På grunnlag av flere års registreringer av en egnet indikator (storfugl), satte kommunen i samarbeid med fagekspertise fra universitetet i 2006 i gang en mer omfattende sårbarhetsanalyse. Denne viste at vi nå nærmet oss en kritisk grense for livsvilkår for sårbare viltarter i kjerneområdene i Trondheim Bymark. Konstruktiv dialog med den statlige grunneier i området, Statsskog, førte til en felles forståelse for at høy biologisk verdi var i ferd med å gå tapt. Hogst i regi av Stasskog ble derfor stoppet fra 2007. Kunnskap har også medført at hensynet til biologisk mangfold i sterkere grad er kommet til uttrykk i kommunens forvaltningsplan for skog og i forhold til tilrettelegging for friluftslivet. Lærdomra prosjektet:

- Godt kunnskapsgrunnlag gir et svært godt utgangspunkt for forståelse av å ivareta biologisk mangfold. 
- God kompetanse og engasjement i kommunen er viktig for å utvikle konstruktive samarbeidsrelasjoner.

- Det må legges stor vekt på informasjon for å motivere private skogeiere for å ta hensyn til biologisk mangfold i den daglige drift. Det må skapes «eierforhold" til prosjektet.

- Den samfunnsmessige gevinsten av å ta vare på sårbare viltarter må synliggjøres.

- Viktig med god kontakt med ulike kommunale instanser som representerer forskjellige interesser i området som f.eks friluftsforvaltning og skogbruk. 


\section{Vanda kommune}

Vanda, Helsinkis nabokommune i nord og Finlands fjerde største stad, har lange tradisjoner for naturvern. Det første naturvernområdet ble etablert $\mathrm{i}$ 1946 basert på en vakker eikeskog. I 2007 økte naturvernområdene fra $2 \%$ til $6 \%$ av det totale kommunearealet. Vandas innmeldte prosjekter omhandler "kommuneplanen som verktøy", landskapsprosjektering rundt en jordtipp for rene jordmasser og fornying $\mathrm{i}$ allmenne prinsipper for skogvern.

\begin{tabular}{ll}
\hline Invånare (1.1.2009) & 195397 \\
Total areal, $\mathrm{km}^{2}$ & 240 \\
Vatten areal, $\mathrm{km}^{2}$ & 2 \\
Skog areal, $\mathrm{km}^{2}$ & 90 \\
Ảker areal, $\mathrm{km}^{2}$ & 50 \\
Befolkningskoncentration, invånare $/ \mathrm{km}^{2}$ & 813
\end{tabular}

\subsection{Den biologiska mångfalden i Vanda}

I Vanda är naturen nära och det finns rikligt med grönområden. Den biologiska mångfalden är på många sätt en resurs som stöder stadens tillväxt och utveckling, den inverkar på trivseln inom bostads- och arbetsplatsområdena och invånarnas möjlighet till fritidssysselsättningar. Den biologiska mångfalden spelar också en viktig roll som uppväxtmiljö för barnen och när det gäller att skapa ett livslångt förhållande till naturen.

Vandas stora grönområden med sina skogar och åar representerar en varierande och rik sydfinländsk kustnära natur. Huvuddragen i stadens landskapsstruktur utgörs av berg- och moränåsar och ådalar med lerjordar mellan åsarna. Typiska element i Vandas landskap är skogar och stora odlingsområden som delas itu av Vanda å med biflöden.

I Vanda hittar man exempel på de flesta av södra Finlands mest framträdande naturtyper. Växtgeografiskt sett ligger Vanda vid den norra gränsen av ekens utbredningsområde. Den hemiborealiska zonen, d.v.s ekzonen, täcker Finlands sydligaste kustområden och den södra skärgården, och den sydborealiska zonen d.v.s barskogsregion sträcker sig till Insjöfinland och Bottniska vikens kust. 


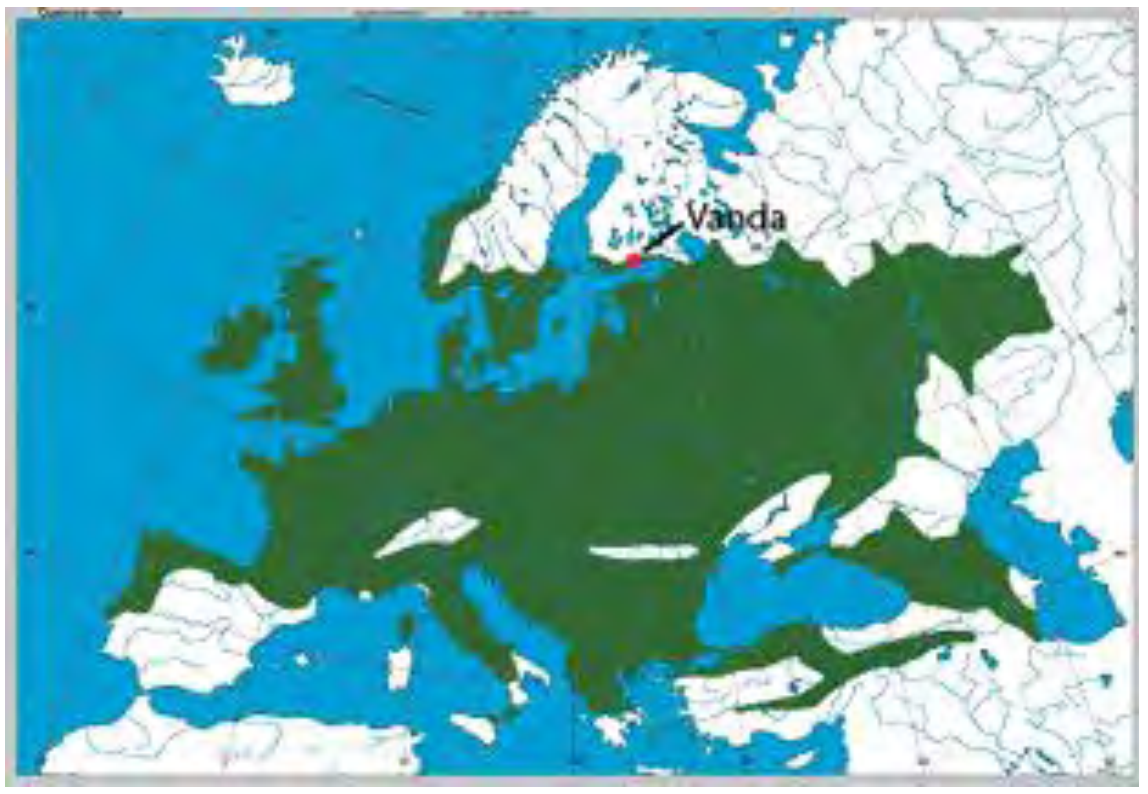

Fig. 87 Den hemiborealiska zonen (Wikipedia).

\subsection{Projekt 1. Kommunal generalplan som verktyg vid bevarandet av naturens mångfald på lokalnivå}

\section{Beskrivning av projektet}

Vanda stad har långa traditioner då det gäller generalplanering och befrämjandet av naturvård. Den första generalplanen godkändes år 1983 och en stor naturinventering gjordes år 1981. I samband med generalplanen 1992 gjordes omfattande och mångsidiga inventeringar av såväl natur- som miljödata. Generalplanen 1992 utgjorde basen för Natura 2000-reserveringar i Vanda.

I den nya generalplanen (2007) har naturinventeringarna ytterligare kompletterats. Projektet presenterar hur Vanda stad har utnyttjat den kommunala planerings- monopolen för befrämjandet av naturvård och biologisk mångfald på lokal nivå.

\section{Projektets mål i förhållande till den biologiska mångfalden}

Generalplanen 1992 och dess naturskyddsreserveringar utgörde basen för arbetet med bevaring av naturens mångfald i förslaget till generalplan 2007. Därtill har en systematisk naturinventering pågått åren 1995 - 2007. Artkarteringar som gjorts är bl.a. växter (1980-1990 och 2000-talet, 2004), fåglar (1990-talet, 2000, 2003, 2004), fladdermöss (2001-2003), flygekorre (2002,2005), trädsvampar (2005), fjärilar och andra insekter (2004, 2005). Andra karteringar är: fredade naturskyddsobjekt i Vanda (2006) och kartläggning av små vattendrag i Vanda (2009) Därtill har bl.a. följande regionala utredningar utnyttjats; Nylands läns värdefulla kulturlandskap (2000), Ekologiska nätverk i Nyland (2001),Värdefulla bergsområden i Nyland (2004) och Vidsträckta sammanhängande skogsområden (2007). 
Förutom reserveringarna för naturskyddsområde i generalplanen, innehåller planen ett nytt element, nämligen en generalplane betäckning kallad "Luo". Det är fråga om vanligtvis små områden, som är värdefulla pga. sin biotop, artförekomster eller andra naturvärden. Dessa områden förekommer ofta i grönstrukturen, vid idrottsparker eller andra allmänna områden, där de binder samman separata naturområden med varandra. Planebetäckningen "Luo" betyder att området skall skötas med beaktandet av naturens mångfald.

Arbetet med naturens mångfald (Luo) baserar sig på bearbetning av tidigare inventeringsdata samt fältstudier av biologen Anna Ojala (2005).

Tryggandet av naturens mångfald i Vanda baserar sig på tre nivåer, dels utgör naturskyddsområden kärnan med sina 1450 ha naturskyddsområden. Därtill kommer "Luo" på ca 800 ha som kompletterar naturskyddsområden i den allt tätare stadsstrukturen. Slutligen har vi de övriga grönområden på 5 700 ha som innehåller såväl små närparker, strand zoner vid åar och bäckar som stora idrottsparker. På Luo-områden strävar man att koordinera olika aktiva markanvändningar med skyddsvärden.

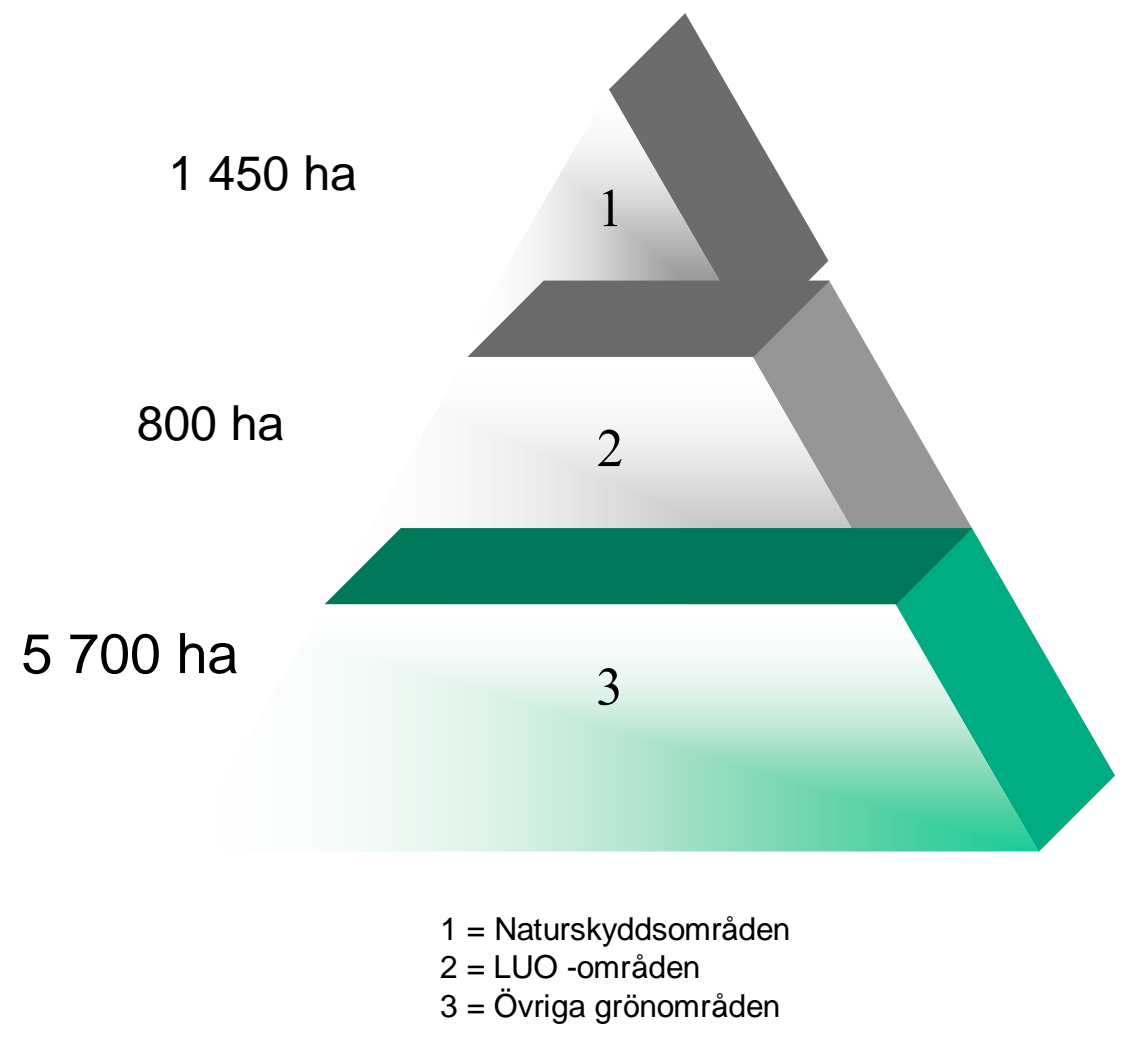

Fig. 88. Basen för Vandas arbete med den biologiska mångfalden är naturskyddsområden och de stora övriga grönområden, som tillsammans med "Luo"-områden bildar ekologiska grönstrukturer. 


\section{Genomförda åtgärder}

Generalplanearbetet påbörjades år 2004 med en för allmänheten öppen debatt om den nya generalplanens mål. Därefter utarbetades utkastet till generalplanen år 2005. Under detta arbetsskede deltog Vanda stads miljökontors experter aktivt i olika arbetsgrupper som behandlade natur- och miljöskyddsfrågor. Utkastet till generalplanen var satt till allmänt påseende och remissrunda i början på året 2006. Feedback var allmänt tagen positiv och kunde utnyttjas vid vidare arbete med själva förslaget till generalplanen som blev färdig våren 2007. Reservering av några miljöbelastande verksamheter ledde till stor aktivitet hos allmänheten, men däremot förorsakade inte naturskyddsreserveringarna eller Luo-områden större debatt.

I december 2007 har Vanda stads fullmäktige godkänt generalplanen och 3.6.2009 trädde generalplanen i kraft.

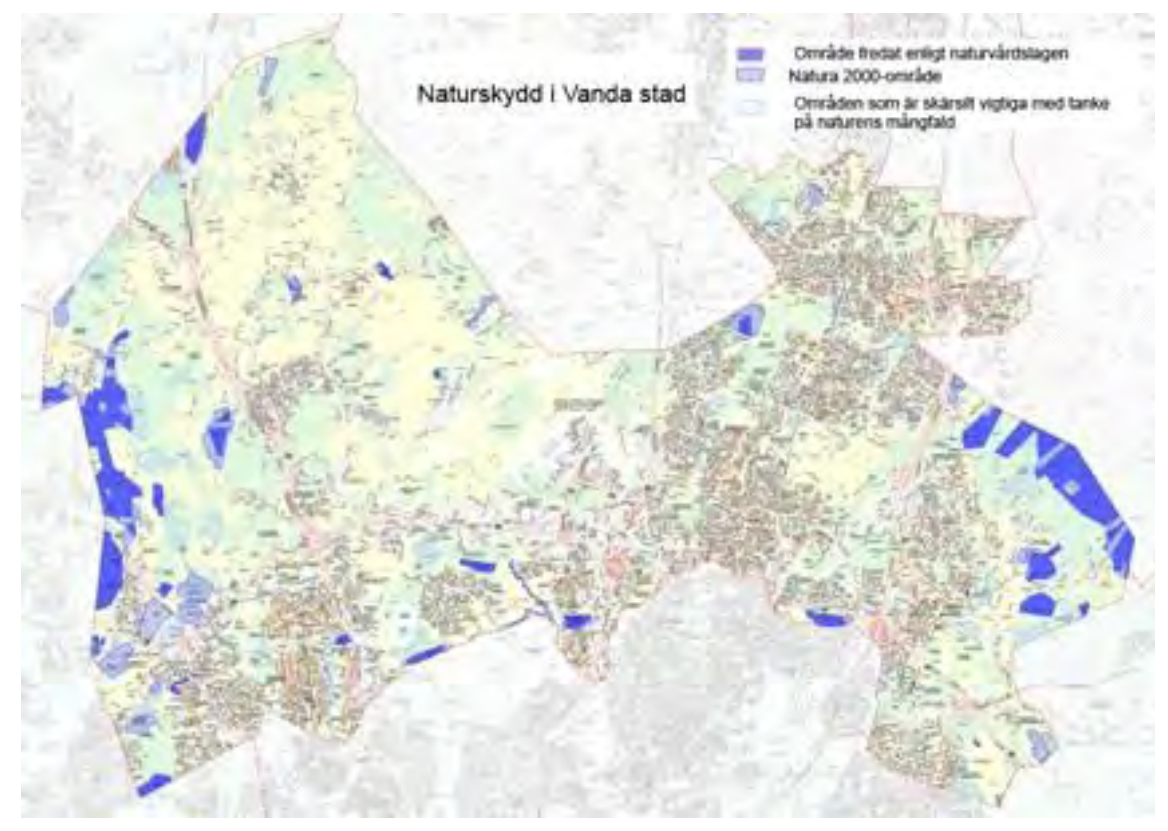

Fig. 89 Naturskydd $i$ Vanda stad.

\section{Resultaten som har uppnåtts}

Fredningen av naturskyddsområden samt vård och skötsel av dessa utgör en viktig del av det lokala arbetet med bevarandet av naturens mångfald. År 1990 var ca 15 ha av Vandas värdefulla natur fredat enligt naturskyddslagen. I slutet av år 2008 var motsvarande areal ca 865 ha. Av de fredade områden är $95 \%$ kommunägda. Målet är att ca $6 \%$ av Vandas totala areal skall fredas som värdefull natur.

I november 2007 har Vanda dessutom via markbyten med finska staten överfört ca 250 ha i generalplanen reserverade naturskyddsområden till Forststryrelsen för bildandet av den planerade nationalparken "Sibbo storskog". Det är fråga om ett totalt ca 1800 ha stort skogsområde, som är beläget på tre skilda kommuners område. Storskogens område i Vanda är ca 300 ha, varav största 
delen byttes med staten. Tack vare Vandas inventeringar, har Sibbo storskogs nationalparksplaner utvidgats.

\section{Uppföljning}

Uppföljningen av generalplanens förverkligande har börjat. Förekomsten av Luo-områden har lett till att åtgärder på dessa områden alltid kräver konsultation med miljökontoret.

Den godkända generalplanen (kommuneplan) innehåller i stort sätt de viktigaste naturskyddsområden i Vanda. Efter en intensiv period av naturinventeringar åren 1981-2005 har ett viktigt skede av naturvårdsarbetet blivit färdig i Vanda.

Det följande skedet är att göra upp skötsel- och användningsplaner för naturskyddsområden samt reservera resurser för förverkligandet av dessa planer under 2010-2014.

\section{Erfarenheter}

Trots att Vanda är Finlands fjärde största stad med ca 195000 invånare och har Finlands största internationella flygstation, har staden lyckats väl i sitt arbete med bevarandet av biologisk mångfald.

Ett systematiskt arbete med naturinventeringar, där även lokala naturvårdsföreningar och biologer har deltagit, har haft en stor betydelse.

Samarbetet med stadens övriga expertis, framförallt stadsplaneringen har varit fruktbart. De politiska beslutsfattarna har till stor del godkänt naturskyddsreservationer och arbetet med den biologiska mångfalden. Samtidigt med generalplaneringen har Vanda köpt en stod del av naturreservationerna, men även privat mark har fredats.

I de nordiska länderna har kommunen en stark ställning då det gäller markanvändning. Vandas modell, där man med markändvändningsplaner byggt upp ett ekologiskt nätverk samt värnat om den biologiska mångfalden är ett fungerande arbetssätt.

\subsection{Projekt 2. Förnyandet av Vanda stads principer för skogsvård}

I Vanda finns det cirka 9000 hektar skog, dvs. omkring en tredjedel av Vandas hela areal. Vanda stad äger och sköter 3700 hektar av dessa skogar. De största enhetliga skogsområdena är belägna i Vandas västra och östra delar samt i norr vid gränsen till grankommunen Tusby. Förhärskande skogstyper är grandominerad skog av blåbärstyp och skog av harsyrablåbärstyp. Karga moar finns huvudsakligen på bergens grönområden samt på åsarna.

Av skogsmarkens areal är andelen lundar och lundartade skogar stor. I synnerhet i utkanten av odlingsområdena i södra Vanda förekommer ställvis stora, lummiga lundområden. Dessa lundar, som ofta växer på lerjord och är 
rätt så plana eller består av svagt sluttande slänter, är lämningar av större lundskogar som röjts för odling.

Målet för skogsskötseln av Vanda stads skogar för åren 2007-2017 har fastställts i Principer för skogsskötsel. Enligt principerna är Vanda stads skogar rekreationsområden med så stor biodiversitet som möjligt. Skogsvårdens fyra allmänna principer är:

1. Naturens mångfald

2. Målet för all skogsvård är skydda skogarnas livskraft och diversitet. Miniminivån för skyddet av mångfalden definieras av skogslagen, naturskyddslagen och kriterierna för Finlands skogs sertifiering. Vid vården av stadens skogar överskrids miniminivån.

3. Miljövänlig teknik

4. Landskapsvård

5. Vid skogsvården beaktas såväl när- som fjärrlandskapet.

6. Trygga skogar

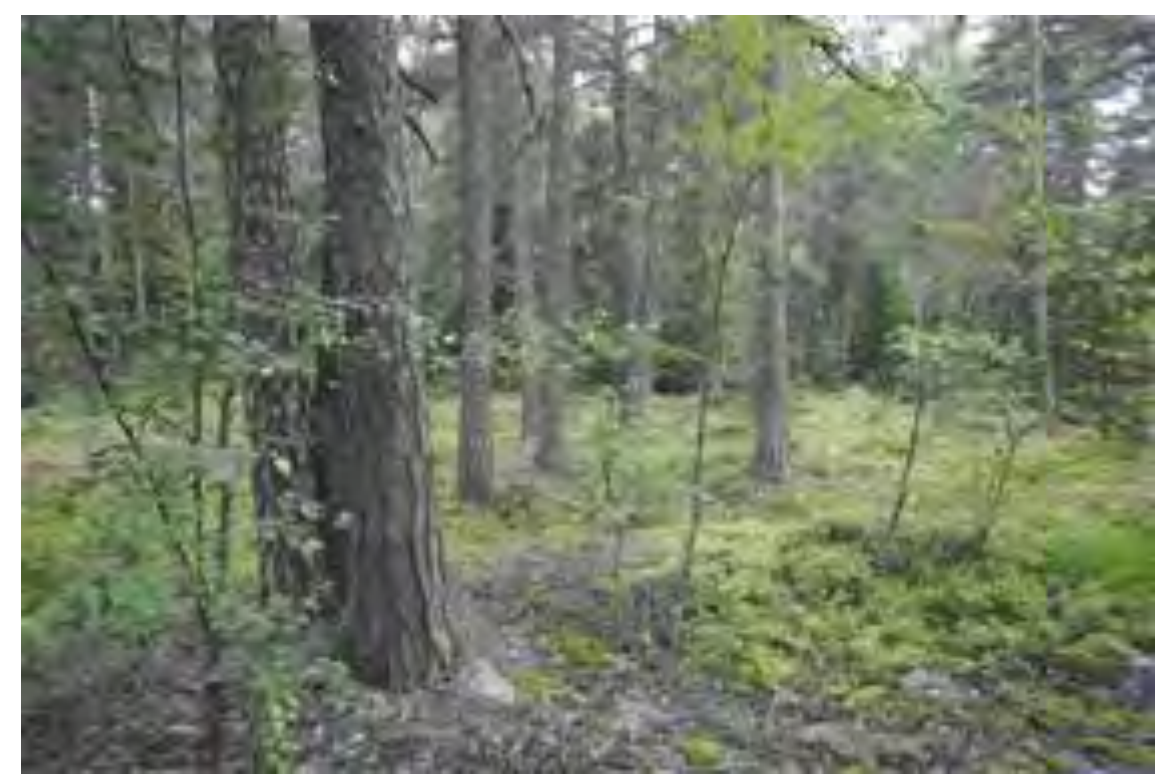

Fig. 90 Skogområde i Petikko. Foto: Vanda kommune.

Projektets mål i förhållande till den biologiska mångfalden

I samband med skötseln av stadens skogar tar man i beaktande att den biologiska mångfalden bevaras och man värnar om skogarnas livskraft. Skötseln av skogarna planeras och utförs som övergripande helheter. Målet med skötseln är att gradvis återställa skogarna så långt det går i naturtillstånd, dock utan att förorsaka problem för rekreationsbruket i skogarna.

I de skogar som Vanda stad äger finns c. 34 ha (20 objekt) med sådana värdefulla livsmiljöer, i enlighet med skogslagen, som är viktiga för den biologiska mångfalden. Närmare hälften av dessa livsmiljöer är i Vanda källor, bäckar eller små träsk. Resten består av olika slags berg och steniga 
ställen. Dessutom innehåller de livsmiljöer som motsvarar skogslagen en brunmosse och ett lundområde.

I Vanda finns det också naturtyper bestående av skog som är fridlysta enligt naturvårdslagen, dessa utgör 27 hektar (10 objekt). Största delen av dessa skogar är bestånd med ädelträd och hassellundar, däribland finns desssutom ett klibbalskärr. Alla Vanda stads skogsområden har ännu inte kartlagts. Därför känner man inte ännu exakt till alla värdefulla livsmiljöer och naturtyper och fler nya områden som är värdefulla för den biologiska mångfalden lär hittas i framtiden.

Enligt skogsvårdsplaner skall den biologiska mångfalden i de skogar som staden äger öka till exempel genom att man bevarar gamla skogar, randområden, bäckar, små våtmarker och övriga platser som bidrar till en ökad mångfald. Dessutom bevaras livsmiljöer för nationellt och regionalt hotade eller regionalt sällsynta arter. Murkna träd är mycket viktiga för skogsnaturens mångfald och man strävar också efter att öka mängden av murket trä. Det vill säga att gamla solitära träd, högstubbar, andra murkna träd, hålträd och markträd samt enstaka vindfällen bevaras som grönområden i de planlagda skogarna.

\section{Genomförda åtgärder}

Vanda stads skogsvårdsplaner för de kommunägda skogsmarkerna förnyades enligt de nya principerna 2006-2009 för följande tioårsperiod 20082017. Fältarbetet började år 2006 och fortsatte sommaren 2007. Under år 2007 färdigställdes sex regionala förslag till skogsvårdsplaner, representerande hela Vanda. En biolog har deltagit i fältarbetet, då man fastsällt område som är värdefulla för naturens mångfald. På dessa områden har inte föreslagits skogsvårdsåtgärder.

Planeringsutkasten presenterades för kommuninvånarna runt om i staden. Under år 2008-2009 behandlades planeringsutkasten i Vanda stads nämnder, även miljönämnden.

\section{Resultaten som har uppnåtts}

Skogsvårdplaner har godkänts av stadsfullmäktige. Åtgärdstillstånd som kommunens miljökontor ger har beviljats för tre av sex regionala skogvårdsplaner. Skogvårdplanerna styr stadens skogsvård även om de inte har godkänts av miljönämnden.

\section{Uppföljning}

Innan Vanda stads enhet för grönområden inleder skogsvårdsåtgärder måste man meddela nästa hyggesperiods åtgärder till miljökontoret. Detta beror på den långa tillståndsperioden.

\section{Erfarenheter}

Principerna för Vanda stads skogsskötsel och skogsvårdsplaner utarbetades i gott samarbete mellan stadens olika experter. Dessutom hade man representan- 
ter för den lokal naturvårdsföreningen med i arbetsgruppen. Intresserade kommunbor hade även möglighet att kommentera principer för skogskötseln.

\subsection{Projekt 3. Utveckling av natur- och rekreationsområdet Petikko med beaktande av naturens mångfald}

Petikko-området är ett i västra Vanda beläget enhetligt, i det närmaste obebyggt skogsdominerat grönområde, som är ca 1700 ha stort. Petikkoområdet är populärt och används såväl sommar- som vintertid av invånarna. För att utveckla området tillsattes en arbetsgrupp år 2006. I gruppen arbetade experter från kommunens olika sektorer. Arbetsgruppens uppgift var att planera området som helhet, koordinera användandet av de kommunägda naturskydds- och rekreationsområden samt främja förverkligandet av planer. På området finns också 10 föreningar, som idkar hobbyverksamheter, såsom hundskolning, pilskytte och flygning medmodellflygplan. Arbetsgruppens förslag till skötselplan blev färdig 31.12.2008.

\section{Projektets mål i förhållande till den biologiska mångfalden}

Petikko område ar en viktig del av det grönbälte som går runt Helsingfors. Över hälften av Vanda stads naturskyddsområden ligger i Petikko samt en stor del av generalplanens Luo-områden. Området är mycket populärt som rekreationsområde. Tanken är att ge kommuninvånare en god bild av naturen och rekreationsmögligheter i Petikko.

\section{Genomförda åtgärder}

Arbetsgruppen träffades regelbundet år 2006-2008 (16 gånger) för samtal och diskussion kring utveckling av Petikko. Gruppen gjorde en studieresa till Skogstyrelsens rekreationsområde Teijo sydvästra Finland. Invånare hade möglighet att bekanta sig med planerna och påverka utvecklingsplanerna vid diskussionstillfällen. Landskapsarkitekt Katariina Rautio var anställd år 2007 för att främja arbetsgruppens uppgift. Hon gjorde en grundläggande utredning av området.

Då det nordiska projektet "Lokal medvirkning for å stanse tap av biologisk mangfold" besökte Finland i september 2008, presenterades Petikkoområdet för projektkommunerna.

I slutrapporten arbetsgruppen föreslog en mängd med åtgärder för att utveckla området;

- komplementtering av friluftleder och stigar, även skidspår och ridrutter,

- ny enhetlig infoskyltning och övrig guidning på området,

- två nya parkeringsplatser byggs, därtill ombyggs huvudparkeringen till "Porten till Petikko",

- förbättring av rast- och konditionsplatser samt övernattningsområden skall göras, 
- uppgörande av skötsel- och användningsplaner med beaktande av naturens mångfald på naturskyddsområden, åker-, skogs- samt myrmarker,

- utveckling av områdets små vattendrag och våtmarker med beaktning av naturens mångfald,

- planer för Långmossens jordtipp (+ 70 m över marken) efter stängningen 2014, varma syd- och västsluttningar reserverade för terrängcykling, naturliga växtbiotoper skapas,

- koordinering av områdets hobby- och företagsverksamhet med naturoch rekreationsintressen,

- effektivering av områdets tillsyn då det gäller nedskräpning och körförbudet med motorfordon,

- förbättrad info via internet om områdets service samt utreda möjlighet att öppna en naturskola,

Rapporten var på remissrundan våren 2009 och behandlades i miljönämnden och i stadsstyrelsen 2009. Rapporten godkändes utan ändringar.

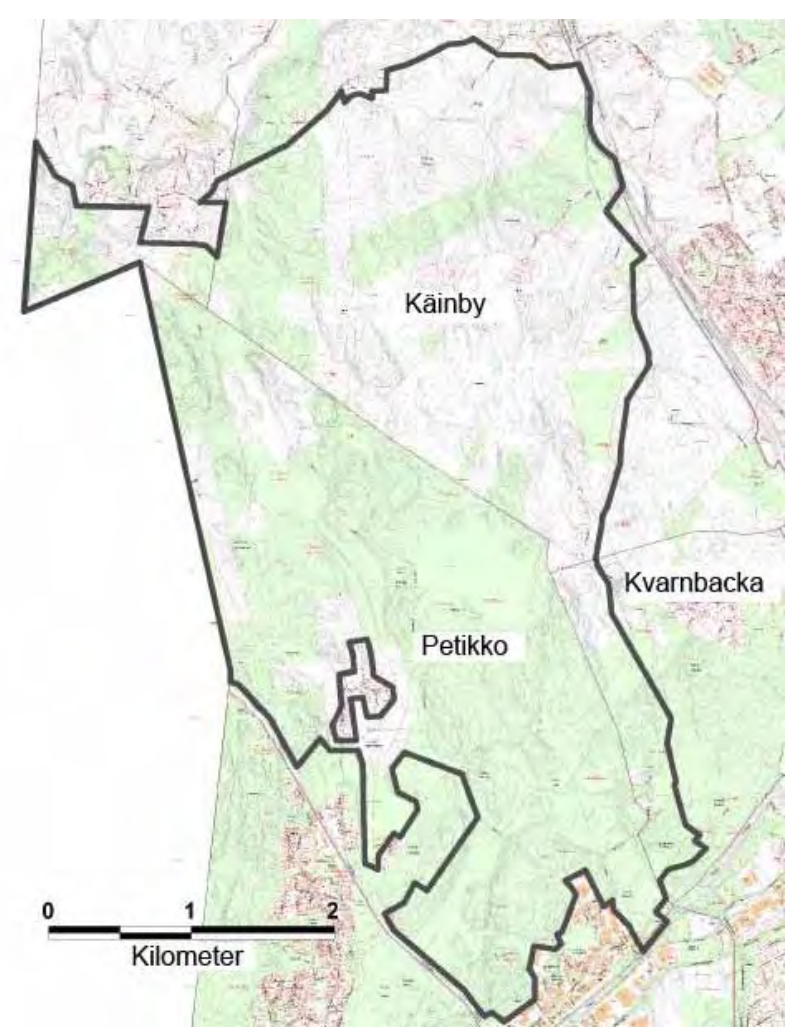

Fig. 91 Planeringsområdet i Petikko, det gröna området ägs av kommunen. På det vita området vid Käinby är en golfbana.

\section{Resultaten som har uppnåtts}

Mottagandet har varit positivt bland invånarna, grannkommunen, av statliga miljömyndigheter och NGO. Budgetreserveringar görs och åtgärderna skall utföras under åren 2010-2014. 
Detaljplaner för huvudparkeringsplatsen "Porten till Petikko" är färdiga. Byggandet börjar år 2010.

Övervakning av otillåten terrängkörning har lett till resultat och körningen i områden har minskat. Samarbetet med polisen och Vanda idrottskansli har varit gott

\section{Uppföljning}

På hösten 2009 tillsattes en ny uppföljningsgrupp som sammankallas två gånger per år. Arbetstid för denna grupp är 2010-2014. Arbetsgruppens viktigaste uppgift är att säkerställa förverkligandet av de godkända planerna så att området utvecklas till ett mångsidigt och fungerande naturrekreationsområde.

\section{Erfarenheter}

Utvecklandet av Petikko stora naturskydds- och rekreationsområde, där det finns många aktörer med olika intressen, är en krävande uppgift. En arbetsgrupp med experter som representerar olika sektorer och som diskuterat med aktörerna på området samt hört lokalbefolkningens åsikter, har lyckats skapa en helhetsbild av de åtgärder som är behövs för områdets utveckling. 


\section{7. Ørebro kommune}

Ørebro, en grønn by med våtland og Svartån. I denne kommunen har en tidligere søppelfylling blitt omgjort til naturreservat og en tidligere oljehavn blitt gjort om til dampark.

\subsection{Från bakgård till naturreservat}

Sjösänkningen i Hjälmaren ägde rum under sent 1800-tal. Avsikten var att torrlägga och odla upp de jättelika våtmarker som då fanns på Närkeslätten. Här i Örebro skapades ett nytt torrlagt markområde mellan sjön och staden. Marken var litet för blöt och svår att odla. Den övergavs och förvandlades sakta men säkert till stadens bakgård. Här låg flera stora soptippar, den största var i bruk ända till sent 1980-tal. Norr om Svartån fanns ett industriområde, en oljehamn och ett stort militärt övningsområde. Området växte också igen med skog, sly och vass. Under åren 1993-2010 har ett jättearbete pågått för att återskapa det forna landskapet. Idag är naturreservatet Oset och Rynningeviken en stadsnära grön oas för oss alla. Och man har nästan glömt att det såg ut så här.

\subsection{Strandskogarna, en spännande miljö}

De allra finaste strandskogarna i Oset och Rynningeviken har sparats. Skogarna får växa fritt. De blir ofta översvämmade under våren och bjuder på en spännande urskogsmiljö full av grodor, insekter, växter av många slag och fåglar förstås. Här trivs fåglar som älskar gamla träd eller trygga snår, till exempel mindre hackspett, stjärtmes, svartvit flugsnappare, bofink, rödhake, järnsparv och sångare av många olika slag - här finns stor chans att höra näktergalen drilla!

\subsection{Vassarna och de grunda vikarna}

Intill den gamla sjökanten har variationsrika områden med vass bevarats. Också detta är ett led i arbetet att behålla de allra rikaste miljöerna och för att skapa fina och trygga livsrum för otaliga fåglar. Här lever många olika arter, till exempel sävsparv, sävsångare, trastsångare, häger, rördrom, vattenrall och brun kärrhök. De bygger sina bon inne i vassarna och buskagen och får på så vis ett gott skydd. 


\subsection{Beteslandskapet och blomsterängarna}

Beteslandskapet vid Venan är byggt ovanpå en stor soptipp. Det är lite svårt att tro när man idag blickar ut över ett böljande hedlandskap med små grönskande öar och stenpartier. Här betar får och nötboskap friskt gräs tack vare sinnrika markkonstruktioner som bildar ett tjockt skyddande skikt mot det gamla sopberget. Från den högsta punkten vid raststugan har du en strålande fin utsikt över hela beteslandskapet och sjön Hjälmaren. Promenera också genom Vattenparken intill Naturens hus och njut av blomsterängar med över 200 olika växtarter.

\subsection{De återskapade strandängarna}

Med hjälp av pumpar och låga vallar som byggts längst stränderna mot Hjälmaren kan vi återskapa forna tiders översvämmade strandängar. Under våren och försommaren bildas här grunda vattenbassänger som är högintressanta som rast- och häckningsområde för mängder av fåglar. Och fåglarna har återvänt, här finns nu gulärlor, svanar, strandpipare, hägrar, tofsvipor, gäss, brushanar, krickor, årtor, rödbenor och många fler. Och det går att komma dem riktigt, riktigt nära tack vare att vallarna också fungerar som cykel- och vandringsslingor.
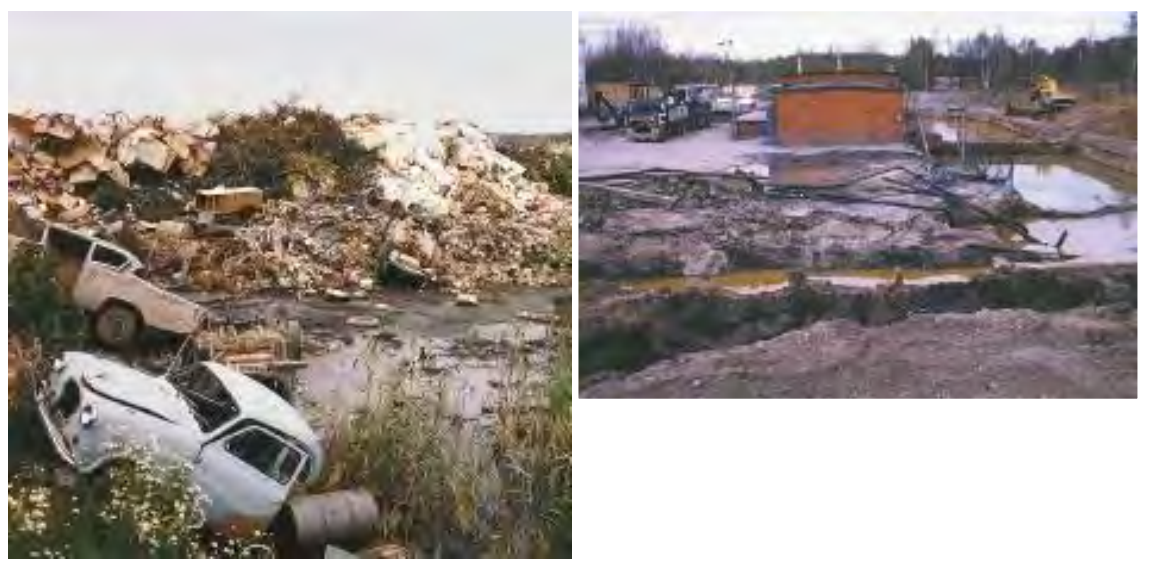

Fig. 92. Slik så området ut på 80-tallet før restaureringsarbeidene startet tidlig på 90-tallet. Foto: Ørebro kommune. 

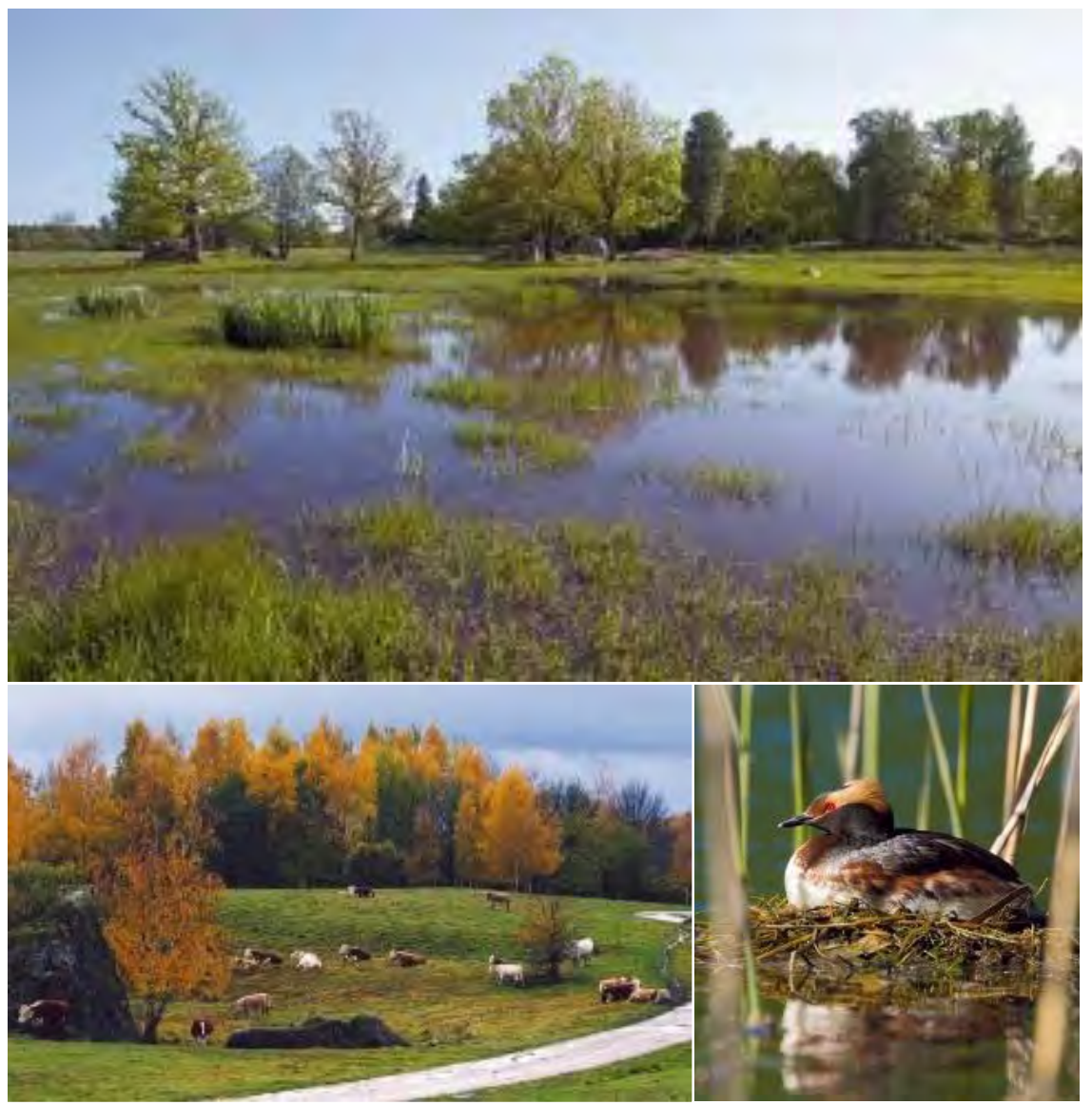

Fig. 93. Etter omfattende restaureingsarbeider i tiden fra 1993 og fram til 2010 er de samme områdene (se Fig. 92) gjenskapt til grønne oaser med et rikt plante og dyreliv.

Foto: Ørebro kommune.

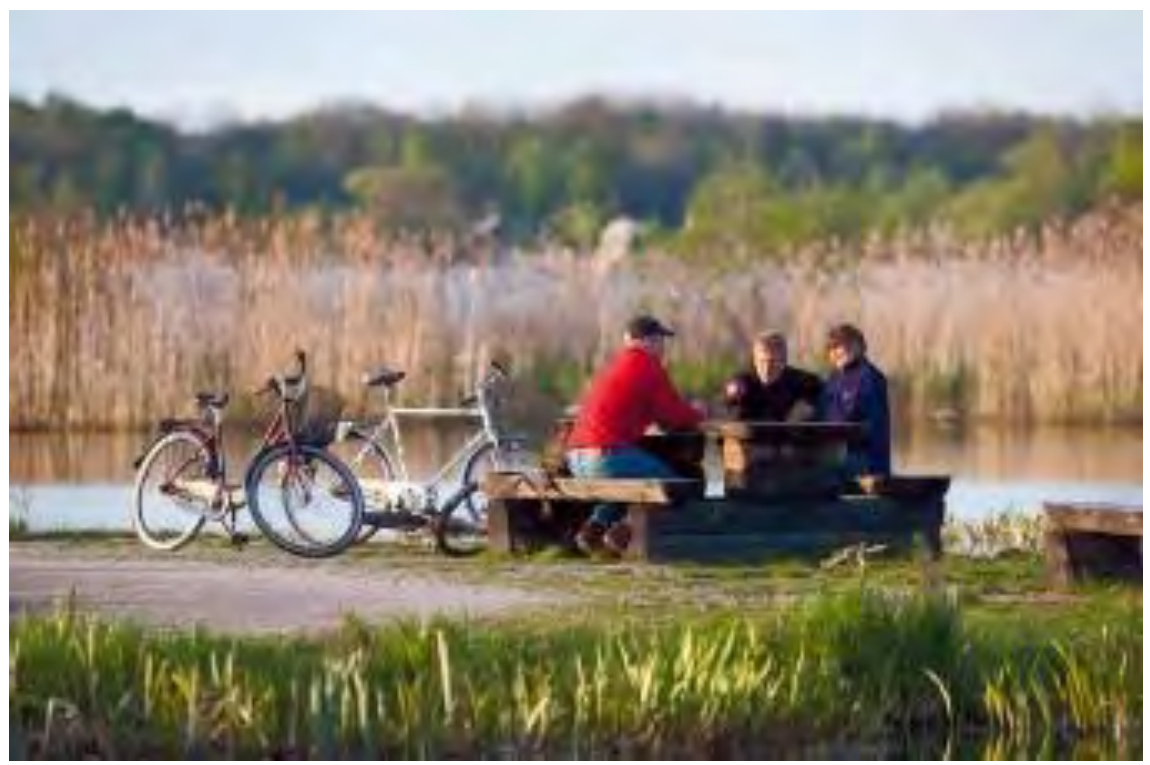

Fig. 94. De restaurerte områdene er i dag et populcert utfartsområde. Foto: Ørebro kommune. 



\section{Samantekt}

Norrænt átaksverkefni til verndunar á fjölbreytni lífríkis undirstrikar mikilvægi pess að staðbundnar lausnir séu próaðar og sveitarfélögin taki ábyrgð í pessum efnum, pví peirra er skipulagsvaldið. Hér er sagt frá 30 afmörkuðum verkefnum sem mörg sýna að með einföldum aðgerðum má finna lausnir sem duga til að viðhalda fjölbreytni tegunda lífvera á viðkomandi svæði.

Átaksverkefnin voru mismunandi og áætlanirnar gengu út á t.d. pað að tryggja varðveislu pess sem fyrir var eða að endurheimta einhver gæði sem hafði verið spillt, m.a. með endurskoðun skipulags eða með pví að hefta útbreiðslu ágengra tegunda. Hér fylgir stutt samantekt um verkefnin sem nánar er lýst í sérstakri skýrslu frá hverju sveitafélagi.

\section{Akureyri}

Skipulagt útivistarsvæði ofan bæjarins, í mynni Glerárdals, par sem sorp var urðað til skamms tíma, var snyrt og jafnað. Áformað er að endurheimta gróður á svæðinu með pví að dreifa og sá íslenskum tegundum sem vaxa á svæðinu. Markmiðið er að endurheimta landslag og gróðurpekju svo svæðið falli vel að óröskuðu umhverfinu.

Tvær framandi tegundir gróðurs, skógarkervill (Anthriscus sylvestris) og alaskalúpína (Lupinus nootakensis) hafa dreifst yfir Hrísey í Eyjafirði og kæft par náttúrulegan gróður. Détt og nánast samhangandi útbreiðsla pessara tveggja tegunda pekur 11-13\% af flatamáli eyjarinnar nú, en reynt hefur verið að slá reglulega reiti á svæðinu og sá síðan íslenskum gróðri í tilraun til að endurheimta fjölbreyttari gróðurbekju á svæðinu.

Naustaborgir eru innan útivistasvæðis norðan Akureyrar. Landið hafði verið ræst fram og jafnað út, til landbúnaðar. Nú hefur verið mokað aftur í skurði til að endurskapa parna búsvæði fyrir votlendisfugla. Grunnvatnsyfirborð hefur hækkað og vatn safnast í tjörn. Aðkoma að svæðinu hefur verið lagfærð og göngustígar skipulagðir.

\section{Álftanes}

Endurheimt votlendis, par sem nú er framræst mýri við Kasthúsatjörn. Törnin er friðuð og mikið notuð af andfugli. Áform eru um að stækka friðlandið, leggja göngustíga um svæðið og setja upp skilti til að benda á mikilvægi pess að sýna tillitsemi yfir varptímann. Nálægðin við opin svæði á ríkisjörðinni Bessastöðum eykur vægi friðlandsins.

Í fólkvangi á Hliðstanga var lengi stórt kríuvarp og mikið af sandlóu og tjaldi. Eftir að hluti svæðisins var hækkað og jafnað út dreifðist hávaxið gras og alaskalúpína yfir flötina og kaffærði varplandið. brátt fyrir hagstæð fæðuskilyrða, mikilla grynninga, hopaði fuglinn. Landslag var endurskapað 
og fjörusandi dreift yfir og vorið 2009 mættu kríur og aðrir fuglar á svæðið við Dvottatjörn og hófu að verpa par á ný.

Borgå

Sveitafélagið skilgreindi hluta bæjarlandsins sem fólkvang, árið 2010.

Bæjarfólkvangurinn varðveitir sérkenni sem veita innsýn í sögu bæjarins. Yfirlýsingin um að bæjarhlutinn skuli vera fólkvangur íbæjarlandinu stuðlar að verndun svæðisins til framtíðar, sem er mikilvægt er bærinn stækkar og prýst er á um aðra nýtingu.

Marens Eng er einn athyglisverðasti reiturinn innan hins nýstofnaða fólkvangs í Borgås. Petta forna beitarland hefur bæði sögulegt gildi og er dæmi um sérstak samfélag gróðurs og dýra. Fornar hefðir um nýtingu svæðisins til beitar er viðhaldið með skipulegum hætti. Svæðið er vinsæll viðkomustaður skólabekkja og pangað eru skipulagðar ferðir til að skoða fjölbreytt lífríkið. Vinsældir svæðisins hafa aukist eftir að pað var skilgreint sem fólkvangur, enda hefur skilningur á mikilvægi pess að varðveita búsvæði fyrir fjölbreyttar tegundir lífvera innan bæjarmarkanna aukist í kjölfar kynningar á svæðinu.

\section{Hammerfest}

Sveitarfélagið hefur látið koma fyrir tilbúnum „fiska”rifjum“, sérhönnuðum bólum á grunnsævi við ströndina. Fiskarifin eru að grunni til greinótt súla gerð úr plaströrum, en á peim vex fljótlega pang. Niðurstöður sýna að áberandi aukningu í tegundafjölbreytni má vænta á peim svæðum par sem petta er reynt. Bólin mynda skjólgóða staði fyrir fiskseiði. Tilgangurinn með bólunum er að pau komi í stað paraskóga og myndi hentugt undirlag fyrir gróður, sem víða hefur verið étinn niður af ígulkerum (skollakoppi). Tilraunin með pessi ból er tækifæri til að rannsaka hugsanlegar mótvægisaðgerðir til endurheimtunnar á illa löskuðum búsvæðum í sjó.

\section{Hedensted}

Í efri hlutar árinnar Skjold hefur verið skapað fjölbreyttari umhverfisskilyrði 1 árfarveginum. Aðstæður til hrygningar hafa verið lagaðar fyrir sjóbirting á riðstöðvum. Votlendissvæði var komið fyrir við ánna til að draga úr sytri nítrats $(\mathrm{N})$ og fosfats (P) í aðrennslisvatni frá landbúnaðarjörðum í nágrenninu. Pessi aðgerð skapaði jafnframt hentugt búsvæði fyrir and- og vaðfugla. Framkvæmdirnar, ásamt byggingu á turni til fuglaskoðunar, hafa aukið gildi svæðisins til útivistar og undirstrikar mikilvægi pess að viðhalda fjölbreytni lífríkisins.

Innan marka Hedensted er minnst 30 mikilvægir reitir par sem vaxa gróðurtegundir sem eru í útrýmingarhættu, viðkvæmar, sjaldgæfar eða sérkennandi fyrir birturíkt umhverfi, í gisnu skóglendi. Svæðið er beitt skipulega til að varðveita slíkt umhverfi og gróðursamfélag á afmörkuðum reitum. 
Í samráði við landeigendur, hefur sveitarfélagið gengist fyrir útgáfu umhverfisskýrteina fyrir skilgreind skóglendi við Vejle Fjord.

Samhliða pessu er unnin veðurfarsáætlun fyrir sveitarfélagið, með samantekt og yfirliti yfir hvar helst má vænta áhrifa veðurfarsbreytinga.

\section{Herning}

Stefna Herning í náttúruvernd og umsýslu var lögð fram árið 2008 og strax næsta ár var hafist handa með framkvæmdir við tíu ólík verkefni, valin í samræmi við áætlunina. Markmiðið er að sjá til pess að viðhalda fjölbreytni í tegundasamsetningu lífvera í sveitarfélaginu og tryggja að komandi kynslóðir geti upplifað og notið fjölbreytni í náttúrunni á stórum samhangandi svæðum, með búsvæðaverndun, endurheimt votlendis og stuðla að skynsamlegri umgengni með kynningum á umhverfinu, dýrum og gróðri.

Framkvæmdir sem tóku mið af að endurskapa aðstæður á neðri hluta Skjern árinnar, eins og pær voru af fyrrum af náttúrunnar hendi, hafa leitt til pess að lax prífst par á ný. Lax gerir miklar og ákveðnar kröfur til umhverfisins, vatnsgæða og botnlags og pví hentar hann sem viðmið á um-hverfisgæði. Vaxandi fiskmergð í ánni mun síðar draga að bæði fugla og otra. Nú pegar hefur verið staðfest að aðstæður hafa batnað, bæði fyrir lax og fyrir hina fágætu árdrekaflugu ,grønn køllegullsmed“.

Veðurfarsbreytingar eru vá sem geta leitt til pess að tegundafjölbreytni lífvera minkar. Margar tegundir eiga erfitt með að aðlaga sig breyttum aðstæðum, flytja sig ekki um set til að forðast breytingar sem gerast á skömmum tíma í náttúrunni og falla pví í valinn. Með hliðsjón af pessari vá hefur verið gerð áætlun um sértækar aðgerðir til að vinna gegn versnandi búskilyrðum. En, pví miður eru breytingarnar og áhrif aðgerða frekar ófyrirsjáanlegar, en aðgerðir til að draga úr $\mathrm{CO} 2$ mengun í sveitarfélaginu Herning eru raunhæft markmið sem getur skilað mælanlegum árangri.

\section{Holstebro}

Í kjölfar nýrra búskaparhátta breyttust hin dæmigerðu engi í Holsterbro er víðitegundir fóru að dreifst um merkurnar. Auk fjölbreytts gróðurs á engjunum preifst par mikið af skordýrum og fuglum. Vegna pessa hóf sveitarfélagið, í samvinnu við landeigendur, að skipuleggja beit sauðkinda, hesta og fleiri grasbýta, til að vernda pessa gerð búsvæða.

Uppistöđulón og tjarnir voru hreinsaðar í Holsterbro í peim tilgangi að gera pær að hentugum svæðum með betri lífskilyrðum fyrir „stor vannsalamander, spissnutefrosk, løkfrosk og strandpadde“. Árangur aðgerðanna er net 88 tjarna og uppistöðulóna sem pessi froskdýr geta nú haldið til í og nýtt sér til fjölgunar.

Fyrrum var algengt í Danmörku að stífla árfarvegi og mynda uppistöðulóntil að rækta fisk. Í nýloknum framkvæmdum voru lögð af fjögur uppistöðulón og endurskapaður árfarvegur á 2,5 km löngum kafla. Мeð pessum aðgerðum batnaði aðgengi fyrir lax, urriða og steinsugur að efri hlutum árinnar. Laxagengd nær nú $23 \mathrm{~km}$ upp í ánna og par með óhindruð umferð að 
meginhluta hennar. Ferskvatnslífverur, sem eru til marks um góðar umhverfisaðstæður, finnast nú aftur í ánni.

\section{Kolding}

Árið 1988 varð, af ópekktum ástæðum afar gruggugt vatnið í tjörninni „Skærsjø“ sem er pekkt fyrir að par vex lobelie-botngróður. Petta kom illa niður á stofnstærð nefndrar gróðurtegundar „tvepibet lobelie“ (Lobelia dortmanna), og sömuleiðis fyrir „,sortgrønn brasenføde“ (Isoetes lacustris) og sniglategundina „strandbo“ (Littorella uniflora), sem allar prífast best 1 í tæru og næringssnauðu ferskvatni. Ástandi hefur skánað aftur, en er bó frekar ótryggt. Einstaklingar af framangreindum gróðurtegundum verða oft paktar af pörungavexti. Sveitarfélagið beitir sér fyrir viðhaldi aðliggjandi votlendissvæða.

Íburður sands í efri hluta árinnar veldur pví að par prífast ekki margar tegundir lífvera, prátt fyrir að par verður vart frekar lítillar mengunar frá landbúnaði. Aðstæður hafa verið betrumbættar í ánni Åkær, m.a. með pví að gera hana bugðótta og bera í hana stein og möl á $17 \mathrm{~km}$ löngum kafla. Pannig hafa verið sköpuð góð skilyrði fyrir urriða, ,smerling“, ársteinsugur og otra.

\section{Nes og Runavik}

Nes og Runavik eru samliggjandi sveitarfélög í Færeyjum. Áætlanir eru umað bora ökufær neðansjávargöng frá höfuðstaðnum, bórshöfn, til Runavik. Gangaopið í Runavik er áformað rétt við sveitarmörkin í Nes í nágrenni við stöðuvatn, Toftavatn. Toftavatn er mikilsvert sakir fjölbreytts lífríkis. Frumrannsókn og skráning á fjölbreytni lífríkisins var framkvæmd árið 2009. Útivistarstígur var lagður til að beina umferð um svæðið í ákveðið horf og par hefur verið komið fyrir viðeigandi upplýsingum.

\section{Stjørdal}

Fjölbreyttum gróðri á beitarsvæðum og í ræktuðum túnum er skákað af runnagróðri. Pví hefur átthagafélagið „Færbøgda i lag“ séð til pess að viðhalda staðbundnum áhuga á pýðingu ræktarlands og hefðum í búskaparháttum. Kortlagning gróðursamfélaga á dæmigerðum engjum hefur skapað faglega kunnáttu sem getur nýst til að stjórna viðhaldi á svæðinu. Umhirða og endurheimt hefur verið staðfest fyrir 17 svæði. Árið 2008 var í fyrsta sinn efnt til „sláttudags“, sem heppnaðist afar vel og verður endurtekið. Tiltakið hefur vakið athygli á verðmæti ræktarlands sem tækifæris sem byggðarlagið getur nýtt sér og spunnið út frá.

Bæði á vorin og haustin er strandsvæðið við Halsøen-Langøra bæði viðkomu- og hvíldarstaður fyrir vaðfugla og andfugla. Mótstríðandi álit eru samt uppi á borðum vegna áhuga á nýtingu og skipulagningu lands í Halsøen-Langøra og pað liggja fyrir tillögur um uppbyggingu á svæðinu fyrir atvinnustarfsemi, stækkun bæjarins, skipulagningu útivistasvæðis og 
lagningu samgöngumannvirkja. Í átaksverkefninu er lagt út frá umræðum um skörun hagsmuna og parfagreiningar skoðaðar ofan í kjölinn.

\section{Trondheim}

Í tilefni af umfangsmiklum vegaframkvæmdum var ákveðið að opna Ilabekken, í Prándheimi. Aðgerðir til að draga úr mengun frá fráveitukerfi bæjarins hafa skilað góðum árangri fyrir vatnsbúskapinn og umhverfið. Framkvæmdir sem miðuðu að pví að bæta aðstæður og búskilyrði fyrir sjóbirting og tryggja pannig viðkomu hans hefur líka skilað góðumárangri. Í ánni hefur orðið vart við hrygningar aðallega hjá sjóbirtingi, en einnig hefur sést til laxa. Pjóðarfuglinn, fossbúi, og otrar virðast líka prífast í endurbættu umhverfi árinnar. Fylgst verður reglulega með framvindu og hugsanlegum breytingum á settum viðmiðunum um umhverfisgæði, í vöktunarverkefni á vegum bæjarins,

Fylgst er með skógarhænsfugli „tiuren (kjäder)“ í Bjørkåsen í Bymarka, í árlegu vöktunarverkefni. Í prándheimi er mikið af villtum dýrum, en hætt er við að stofnar sumra tegunda geti skerst er dregur úr samfellu víðáttumikilla svæða vegna inngripa í náttúrunni. Skógarhænur, tiur, eru notaðar sem viðmið fyrir æskilegt vistkerfi í skógunum. Tiurstofninn nálgast orðið sett viðmið fyrir neðri mörk í fjölda. bví hefur verið stöðvað all viðarhögg frá árinu 2007 og stjórnsýslan hefur ákveðið að hvorki nýir stígar né skíðabrautir verða ruddar á viðkomandi svæði.

Í byggðarlaginu (Lian-Solem), er gömul hefð fyrir landbúnaði og par hefur verið gerð áætlun um hvernig viðhalda megi og tryggja sögulega hefð í búskparháttum og ræktun. Áætlunin gengur út á að hreinsa og ryðja svæði par sem runnagróður hefur verið að dreifast yfir, skipuleggja par reglubundinn slátt og heyskap til að viðhalda peirri tegundafjölbreytni sem prífst við slík skilyrði. Árlega verða gróðursamfélögin vöktuð með rannsóknum, til að tryggja að markmið áætlunarinnar. Мeð samanburði við gögn frá 2001 sést að góður árangur hefur nást og tegundafjöldinn hefur heldur aukist.

\section{Vanda}

Rúmlega helmingur pess lands sem nýtur náttúruverndarákvæða í Vanda, í Finnlandi, tilheyrir svonefndu Petikko-svæði (1700 hektar) en par er ríkt og fjölbreytt lífríki sem er mikils virði heimafyrir. Petikko er vinsælt útivistarsvæði og dregur til sín fjölda manns allan ársins hring. Síðan 2006 hefur hópur fólks unnið að pví að skipuleggja aðgengi og umferð um svæðið með tilliti til nýtingu pess sem útivistarsvæðis og varðveislu hins fjölbreytta lífríkis. Niðurstöður frá vinnuhópnum, með fjölda tillaga um sampættingu náttúruskoðunar og útivistar voru svo lagðar fram 2009. Ákveðið er að vinna samkvæmt tillögunum næstu misserin.

Ný áætlun, sem tekur mið af verndun fjölbreytni lífríkisins, var sampykkt fyrir sveitarfélagið Vanda í desember 2007. Umfang svæða sem njóta friðlýsingar vegna sérstakrar náttúru jókst úr $2 \%$ i $6 \%$ af heildarflatamáli 
sveitarfélagsins. Svæðisbundnar lýsingar og skipulögð vöktun og skráning á plöntum, fuglum, leðurblökum, svifíkornum, trjásveppum, fiðrildum og öðrum skorkvikindum hefur mikið vægi í áætluninni. Náttúruverndarsvæðið er kjarni friðlýstra svæða og nær yfir 1450 ha. Til viðbótar eru samtals 800 ha sem nefnast „LUO-reitirnir“, sem eru sérstaklega mikilvægir reitir sakir staðbundins fjölbreytni í tegundasamsetningu. Hver reitur fyrir sig er afmarkaður og án tengsla við restina af náttúruverndarsvæðinu og pað útheimtir sértækar aðgerðir til að viðhalda peim og vernda, sem sérstök búsvæði. bess utan eru 5700 hektarar skipulagðir sem græn opin svæði, garðar, árbakkar og útivistarsvæði. Skráning fjölbreytilegs lífríkis í Vanda hefur líka stuðlað að auknu umfangi áætlana um stofnun pjóðgarðsins ,Sibbo storskog“. Tillagan um pjóðgarðinn nær til priggja sveitarfélaga og par af eru 300 hektarar skólendis í Vanda.

Markmiðið með verndun skóga er að viðhalda peirri fjölbreytni sem par má finna og tryggja viðkomu lífríkisins. Skráning dreifingar og fjölbreytni lífríkisins hefur pegar átt sér stað og er niðurstöðurnar eru notaðar til viðmiðunar við áframhald vöktunar og umsýslu til að viðhalda fjölbreytni lífríkisins í sveitarfélaginu Vanda. Hvað LOU-reitina varðar er áfram stunduð nýting skóganna á hefðbundinn hátt, sem stuðlar að viðhaldi svæðanna í peirri mynd sem pau voru og nýtingu peirra.

\section{Ørebro}

Með pví að laga til á svæði sem lengi var notað til urðunnar á sorpi, ásamt pví að breyta geymslusvæði fyrir olíu og tilheyrandi hafnarsvæði í garð með uppistöðulóni hefur sveitarfélagið Ørebro eignast votlendi sem dregur að sér fjölbreytt og mikið fuglalíf. Svæðið hefur pví verið gert að náttúruverndarsvæði. Svæðið er gott dæmi um hvernig hægt er að endurskapa landsvæði sem hefur verið gersamlega rústað og gera pað aðlaðandi og vinsælt til útiveru. 


\section{Yhteenveto}

Tässä pohjoismaisessa projektissa osoitetaan kuinka tärkeätä on paikallisella tasolla huolehtia luonnon monimuotoisuudesta sekä kunnan merkittävä rooli maankäytön suunnittelussa. Näistä kolmestakymmennestä paikallisesta projekteistä selviää että on mahdollista tehdä tärkeätä työtä luonnon monimuotoisuuden hyväksi.

Raportin projektit ovat erilaisia aina selkeistä luonnonsuojeluprojekteistä kunnostushankkeisiin, yleiskaavoitukseen sekä vieraslajien torjuntaan. Seuraavassa esitellään lyhyesti kuntien projekteja.

\section{Akureyri}

Entisen kaatopaikan viereen on Glerardalurin ulkoilualueen sisääntuloportti. Kaatopaikka on kunnostettu siten, että käytetään islantilaisen kasvillisuuden siementä kasvillisuuspeitteen palauttamisessa. Tällä tavalla alueen maisemavaurio vähitellen sulautuu ympäröivään alueeseen.

Hrisey-saarella vieraslajit koiranputki (Anthriscus sylvestris) ja hietalupiini (Lupinus nootakensis) ovat ottaneet saaren haltuunsa ja muoodstavat tänään 11-13 \% saaren pintaalasta. Vieraslajien alueet niitetään säännöllisesti ja islantilaisten kasvien siemeniä levitetään monimuotoisuuden lisäämiseksi.

Naustaborgir on Akureyrin pohjoispuolella oleva virkistysalue. Alue oli aikasemmin maatalousmaana, joka oli sekä ojitettu että raivattu. Linnuille on luoto paremmat olosuhteet viheristutuksilla. Veden luonnolliset kulkureitit on palautettu ja lisäksi on rakennettu vesiallas. Alueelle on rakennettu myös polkuja virkistyskäytön parantamiseksi.

\section{Alftanes}

Aikaisemmin kuivatettu kosteikko on kunnostettu ja liikkuminen säädelty. Lisäksi tullaan laittamaan infotauluja kertomaan lintujen pesimisaikaisen rauhoittamisen tärkeydestä. Tämän alueen tärkeys tulee vielä lisäksi korostumaan, koska alue sijaitsee aivan Islannin presidentin linnan ympärillä. Lisäksi alueen rauhoittamisen laajentamiseksi on päätetty.

Aikaisemmin tärkeän lapintiiran, rantasipin ja meriharakan pesimisalueen on valloittanut korkea tiheä ruoho ja lupiinit. Suuret pesimisyhdyskunnat hävisivät vaikka meressä on paljon pikkukalaa. Alue on nyt kunnostettu ja lintulajit ja määrät ovat nousseet.

Porvoo

Kaupunki on valmistellut kansallisen kaupunkipuiston perustamisen vuonna 2010. Kansallisessa kaupunkipuistossa on mukana keskeiset muinaismuisto- 
alueet, historiallisia kaupunkialueita, vakiintuneet vanhat puisto- ja virkistysalueet ja luonnonsuojelualueet.

Maarin niitty on yksi kaupunkipuiston tärkeimmistä alueista. Tällä vanhalla laidunalueella on tärkeä maisemallinen ja kasvitieteellinen merkitys ja toimenpiteitä on tehty jotta alue pysyy avoimena. Alueella käy paljon koululuokkia ja se toimii erinomaisena esimerkkinä miten huolehditaan luonnon monimuotoisuudesta.

\section{Hammerfest}

Kaupunki on tehnyt mereen keinotekoisia karikoita kaloille. Karikot (riutat) on tehty muoviputkista. Toimenpide on selkeästi lisännyt kyseisen rannikon luonnon monimuotoisuutta. Putket toimivat $\mathrm{mm}$. kalanpoikasten suojapaikkoina. Tavoitteena on kompensoida suurten ruskolevien häviämistä, joka johtuu siitä että kovasti lisääntyneet merisiilet syövät kaiken. Nämä keinotekoiset riutat antavat ainutlaatuisen mahdollisuuden tutkia miten voidaan kunnostaa tuhoutuneita meribiologisia ympäristöjä.

\section{Hedensted}

Skjold Å-joen yläosassa on tehty muutoksia joen uomassa. Meritaimenen kutemisen onnistumiseksi on rakennettu särkkiä jokiuomassa. Typen ja fosforin sitomiseksi on myös tehty uusi kosteikkoalue suiston kohdalla. Tämä on myös parantanut sorsalintujen ja kahlaajien elinmahdollisuuksia. Nämä toimenpiteet sekä lintutornin rakentaminen on nostanut alueen merkitystä sekä virkistykseen että sinänsä myös luonnon monimuotoisuuteen.

Hedenstedissä on noin 30 kasvitieteellisesti arvokasta pientä luotoaluetta, joissa esiintyy harvinaisia, taantuvia, rauhoitettuja tai tyypillisiä avoimien biotoppien lajeja. Näiden luontotyyppien monimuotoisuuden edistämiseksi on aloitettu alueiden hoito laiduntamalla.

Kunta on myös yhteistyössä maanomistajien kanssa aloittaneet metsien sertifiointia Vejle Fjordin kohdalla.

Lisäksi kunnassa tehdään parhaillaan ilmastonmuutossuunnitelma, jotta saataisiin selville mitkä alueet eniten tulisi kärsimään ilmastonmuutoksesta.

\section{Herning}

Herningen kunnan luonnonsuojelupolitiikka valmistui 2008 ja seuraavana vuonna aloitettiin 10 erilaista projektia. Ohjelmassa on $\mathrm{mm}$. seuraavia tavoitteita, pysäyttää luonnon monimuotoisuuden häviäminen sekä varmistaa että tuleville sukupolville on edelleen monipuolista luontoa; varmistamalla nykyisiä luontoarvoja, luomalla suurempia yhtenäisiä luontoalueita, uudistamalla entisiä kosteikkoalueita, varmistamalla kunnan alueella olevien kasvien ja eläinten elinympäristöjä sekä välittämällä tietoa luonnonarvoista kuntalaisille.

Lohikaloille on luotu paremmat elinolosuhteet Skjern $\AA$-joen alajuoksun entisöinnillä. Lohi on hyvä indikaattorilaji, koska sillä on kovat elinolosuhdevaatimukset. Kalojen lisääntyminen jokisuistossa houkuttelee paikalle 
sekä lintuja että saukkoa. On todettu että lohi on selkeästi menestynyt samoin kun korentolaji (Gomphus vulgatussimus).

Ilmastonmuutos on suuri huoli luonnon monimuotoisuudelle. Monet lajit eivät kykene muuntautumaan muutosten mukana eikä niillä ole mahdollisuutta siirtyä muualle sopivimpiin paikkoihin. Tämän takia tehdään suunnitelma ilmastonmuutokseen sopeutumisesta, jossa on selkeät tavoitteet. Toimenpiteiden vaikutus luonnon monimuotoisuuteen on vaikea arvioida, mutta Herningen kunnan hiilidioksidipäästöjen vähennys on onnistunut.

\section{Holstebro}

Maatalouden muutosten seurauksena ovat Holstebron tyypilliset niittyalueet hitaasti joutuneet pajupuitteen valtaan. Rikkaan kasvillisuuden lisäksi niityt ovat olleet monipuolisen hyönteis- ja lintulajien esiintymisalue. Alueen palauttamiseksi on kunta yhdessä maanomistajien kanssa siirtäneet lehmiä, hevosia ja muita eläimiä laiduntamaan alueelle.

Vesiliskojen ja eri sammakkolajien kuten viitasammakon (Rana arvalis), kaivajasammakon (Pelobates fuscus) sekä haisukonnan (Bufo calamita) pelastamiseksi Holstebron kunta on kunnostanut peräti 88 vanhaa umpeen kasvavaa lampea ja vesiallasta niiden elin- ja lisääntymisalueeksi.

Tanskassa on aikaisemmin ollut yleistä, että rakennetaan vesialtaita kalantuotantoa varten. Nyt on neljä patoa poistettu ja $2,5 \mathrm{~km}$ entistä jokiuomaa kunnostettu luonnonmukaiseksi. Tämän johdosta lohen, taimenen ja nahkiaisen liikkuminen on helpottunut. Yhteensä lohella on nyt $23 \mathrm{~km}$ vapaata nousua pääuomassa ja hyvää vedenlaatua indikoivia vesieläimiä on myös tullut takaisin jokeen.

\section{Kolding}

Vuonna 1988 muuttui kirkasvetinen "Lobeliajärvi" Saersjö yhtäkkiä sameaksi ja tummaksi. Tämä teki tyypillisten pohjakasvien elinmahdollisuudet mahdottomaksi. Kasvit kuten nuottaruoho (Lobelia dortmanna), lahnaruoho (Isoetes lacustris) ja raani (Littirella uniflora), jotka vaativat kirkasvetisyyttä taantuivat. Tänään tilanne on parempi, mutta edelleen kriittinen. Nämä kasvit ovat usein paksun leväkasvuston peitossa. Kunta hoitaa nykyään aktiivisesti järven valuma-alueen kosteikkoja.

Jos purojen veden laatu on hyvä, voidaan lisätä niiden yläosiin soraa vedessä elävien lajien elinolosuhteiden parantamiseksi. Pienen Åkaer-joen ominaisuuksia parannettiin. Lisäämällä jokeen mutkia ja hiekkaa ja soraa 17 $\mathrm{km}$ matkalla on luotu hyvät olosuhteet meritaimenelle, kivennuoliaiselle ja pikkunahkiaiselle sekä saukolle.

Nes ja Runavik

Nes ja Runavik ovat naapurikuntia Fäärsaarilla. Pääkaupungilta Thorshavnista Runavikkiin on suunniteltu merenalainen maantietunneli. Tunneliaukon ylöstulo on suunniteltu Nesin kunnanrajalle ja aivan Toftavatn-järven viereen. Toftavatn on tärkeä alue luonnon monimuotisuuden kannalta. En- 
simmäinen luontokartoitus tehtiin vuonna 2009. Lisäksi on rakennettu luontopolku herkän luonnon kulutuksen vähentämiseksi sekä alueesta ja sen luonnosta kertovia informaatiotauluja.

\section{Stjördal}

Rikkaat laidun- ja niittyalueet ovat vaarassa kasvaa umpeen ja sen takia kyläyhteisö "Faerbögda i lag" on huolehtinut siitä, että paikallinen kiinnostus kulttuurimaiseman ylläpitämiseksi on hengissä. Niittykasvien kartoitus on antanut hyvän pohjan alueen hoitamiseksi. Nykyään tehdään hoito-ja kunnostus toimenpiteitä peräti 17 alueella. Vuonna 2008 pidettiin ensimmäisen kerran "heinänkorjuupäivä", joka onnistui hyvin ja toiminta tullaan jatkamaan. Tämä työ on osoittanut että kulttuurimaiseman arvot ovat resurssi paikallisyhteisölle joka innostaa aloittamaan myös muuta paikallista toimintaa.

Halsöen-Langöran ranta-aluue on keväisin ja syksyisin kahlaajien ja sorsalintujen levähdysalueena. Tämän alueen maankäytönsuunnittelu on alkanut ja suunnitelmissa on varattu alueita elinkeino-, asumistarkoituksiin sekä virkistys- ja liikennealueeksi. Tämän projektin myötä maankäyttöselvityksen ristiriitaisuudet on voitu nostaa keskusteluun.

\section{Trondheim}

Laajan tieprojektin yhteydessä kunnostettiin Ilabekkenin puro. Toimenpiteet kunnallisten jätevesien vähentämiseksi ovat parantaneet veden laatua. Tämä sekä muut toimenpiteet elinvoimisen meritaimenkannan elinolosuhteiden varmistamiseksi ovat osoittautuneet onnistuneeksi. Purossa on havaittu sekä meritaimenen että myös lohen kutua. Kansallislintu koskikara ja saukko viihtyvät myös uudessa rakennetussa ympäristössä keskellä kaupunkia. Kunta huolehtii säännöllisen seurannan järjestämisestä.

Metsolle on järjestetty vuotuinen kannan seuranta Bymarkassa. Trondheim on laaja kunta, jolla on rikas riistaeläimistö, mutta monen lajin elinolosuhteet ovat heikentyneet metsien pirstoutumisen takia. Metso pidetään hyvän metsän indikaattorina. Metsokanta on nyt joutunut kriittiseen tilaan. Kaikki hakkuut ovat kielletty vuoden 2007 jälkeen ja on tehty poliittinen päätös siitä, ettei uusia polkuja ja hiihtolatuja rakenneta tälle alueelle.

Liam-Solemin kulttuurimaisemassa on järjestetty säännöllistä hoitoa alueen maiseman suojelemiseksi. Umpeenkasvaneen alueen raivaus ja säännölliset niittämiset auttavat alueen monimuotoisuuden palauttamisessa. Vuotuinen kasvitieteellinen seuranta varmistaa, että hoito onnistuu tavoitteissaan. Vuoden 2001 jälkeen kerätyn tiedon mukaan lajien määrä on lisääntynyt.

\section{Vantaa}

Petikko (1700 ha) on tärkeä paikallinen luonnon monimuotoisuuden alue, jossa on noin puolet kaupungin rauhoitetuista luonnonsuojelualueista. Petikko on myös hyvin suosittu virkistysalue sekä kesä että talvoaikaan. Vuodesta 2006 työryhmä on tehnyt työtä sen hyväksi, että alueen virkistyskäyttö ja bio- 
loginen monimuotoisuus voidaan yhdistää. Vuonna 2009 työryhmän toimenpiteet esiteltiin ja lähitulevaisuudessa toimeenpano alkaa.

Joulukuussa 2007 hyväksyttiin Vantaan uusi yleiskaava, jossa huomioidaan myös luonnon monimuotoisuus. Luonnonsuojelualueiden osuus kunnan maapinta-alasta lisääntyy $2 \%$ :sta $6 \%$ :iin. Kaavan taustaksi hyödynnettiin seudullisia selvityksiä sekä tehtiin systemaattista omaa luototutkimusta mm. kasvillisuutta, lintuja, lepakoita, liito-oravaa, kääpiä, perhosia sekä muita hyönteisiä tutkittiin.

Luonnon monimuotoisuuden ytimen muodostaa rauhoitetut luonnonsuojelualueet (1450 ha). Niiden tueksi on yleiskaavassa varattu "Luo-alueita" (800 ha), jotka ovat erityisen tärkeitä luonnon monimuotoisuuden kannalta paikallisella tasolla. Luo-alueet ovat pieniä arvokkaita alueita suojelualueiden ulkopuolella. Muut viheralueet (5700 ha) muodostuvat puistoista, suojavyöhykkeistä ja urheilu- ja ulkoilualueista. Vantaan luontokartoitusten ansiosta Sipoonkorven kansallispuiston laajuuteen on tullut lisäystä. Sipoonkorpi esiintyy kolmen kunnan alueella, josta 300 ha on Vantaalla.

Metsänhoidon tavoitteissa on huomioitu metsän elinvoimaisuus ja monimuotoisuus.

Örebro

Vanha kaatopaikka ja entinen öljysatama muutettiin vesipuistoksi. Tällöin Örebron kaupunki on saanut kosteikon, jolla on rikas linnusto ja alueesta on tehty luonnonsuojelualue. Tämä lähes autio ja saastunut alue on täysin kunnostettu ja siitä on tullut suosittu retkeilyalue. 



\section{Summary}

This Nordic project "Local contribution to halt the loss of biodiversity by 2010 " demonstrates the importance of nature conservation on a local scale, and the key role local authorities play in land-use planning. These local projects show the variety of measures conducted at the municipal level to conserve and restore important habitats for biodiversity.

The projects range from restoration, nature conservation, municipal plans as instruments, and combating alien species to safeguarding species through management.

Akureyri is combating alien species on Hrisey. The introduced species, lupin (Lupinus nootkatensis) and garden angelica (Anthriscus sylvestris), now cover $11-13 \%$ of the island, and seeds are being sown from the native Icelandic flora to restore the areas. Seeds from native plants are also being sown to restore land at a former waste dump in the valley of Glerárdalur. A former wetland at Naustaborgir is being restored to provide a habitat for birds.

Alftanes is improving habitats for birds by restoring former wetlands close to two lakes, Kasthúsatjörn and bvottatjörn. They will also organize public access to the area and regulate the traffic. An undeveloped area surrounding the official home of the President of Iceland will help these two areas to function better in ecological terms.

Porvoo (Borgå) has established a national urban park that includes a great variety of habitats and important cultural environments. Marens Eng, a former pastureland, is one of the most important parts of the proposed park. Tree clearance and grazing will prevent the pasture from becoming overgrown.

Hammerfest has placed artificial reefs in the sea to restore marine habitats that have been destroyed. Pipes made of recycled plastic have been fixed to concrete cylinders. The constructions offer concealment for fish and give seaweed improved living conditions. The aim is to restore some of the kelp forest that has been excessively grazed by sea urchins.

Hedensted will ensure sustainable forestry by certifying forests flanking Vejle Fjord. An area of wetland covering 85 ha (ca. 210 acres), including a 25 ha (61.7 acres) lake, will be constructed. More varied physical conditions in the River Skjold will have positive spin-off benefits for sea trout (Salmon 
trutta trutta), aquatic insects, ducks and waders. Grazing in open environments will secure botanically valuable sites.

Herning is drawing up an environmental policy that will safeguard existing natural assets and create large, continuous areas of countryside. An action plan for salmon in the River Skjern system will improve the living conditions for several species of fish. The salmon is a good indicator species for good ecological conditions. Herning has also placed endeavours to improve the climate high on its agenda. The borough council has initiated several measures that will save energy. Climate change is also a threat to biodiversity.

Holstebro has cleaned ponds to improve conditions for great crested newts (Tritus cristatus), moor frogs (Rana arvalis), common spadefoot toads (Pelobates fuscus) and natterjack toads (Bufo calamita). Grazing has been reintroduced to safeguard open areas of countryside. Weirs are being demolished to improve accessibility for salmon, trout and lampreys.

Kolding will improve water conditions in Skærsjø, a lake known for its water lobelias. Three species, water lobelia (Lobelia dortmanna), lake quillwort (Isoetes lacustris) and shoreweed (Littorella uniflora), are present and all of them like clear, nutrient-poor water. The physical conditions in the River Åkær are being improved by constructing more meanders and placing rocks and gravel along a $17 \mathrm{~km}$ long stretch. Wetlands flanking the Åkær are also being restored.

Nes and Runavik are neighbouring municipal authorities and growing centres of population in the Færoe Islands. Public access to the area surrounding a lake, Toftavatn, has been restricted to safeguard areas of heather and the birdlife. A key feature of this project is providing information on the natural history.

Stjørdal will employ land-use planning to safeguard biodiversity, particularly in shoreline areas where waders and ducks rest. The borough council is also supporting a local association, "Færbøgda $\mathrm{i}$ lag", which is maintaining a local interest for traditional haymaking. The biodiversity of the meadows depends on retaining the traditional land use.

Trondheim is ensuring that streams near the city centre will be in a good ecological state. One of these, Ilabekken, has been reopened and discharge of sewage into it has been stopped, with the result that sea trout and aquatic organisms have returned. The city has an abundance of game within its boundaries, but the habitats of many of the species are being threatened by fragmentation. The capercaillie (Tetrao urugallus) is being used as an indicator species for the desired state of the woodland in Bymarka. Systematic 
management in the Lian-Solem area will safeguard its historical cultural landscape.

Vantaa (Vanda) has long traditions for nature conservation and $6 \%$ of its total area is protected. In addition to these protected areas, a network of local conservation areas (LUO areas) has been established. Special management measures must be introduced here to preserve the biodiversity.

Orebro has converted a former waste dump and a former oil port into a nature reserve and a lakeland park. The restored area amounts to 600 ha (14 826 acres) and is a great attraction for visitors and local people alike.

Based on experience reported by the local authorities taking part in the project, recommendations are given on how to succeed with local biodiversity projects. The most important factors for success which they highlight are local ownership, local and political involvement, competence, local alliances (schools, local NGOs), links to other projects for financing, good relations to regional and national initiatives, and motivation arenas like this project where local authorities can exchange experience across national borders.

The results from these projects can hopefully motivate other local authorities to make efforts to conserve their biodiversity. 
Ved Stranden 18

DK-1061 København K

www.norden.org

\section{Lokal medvirkning for å nå 2010-målet om å stanse tap av biologisk mangfold}

\section{- et bidrag fra 14 nordiske kommuner}

Gjennom det nordiske prosjektet «Lokal medvirkning for å nå 2010 målet om å stanse tap av biologisk mangfold» presenteres resultater fra lokale prosjekter $\mathrm{i}$ 14 nordiske kommuner. Prosjektene som presenteres er varierte, men alle er relevante i forhold til det internasjonale 2010 målet om å stanse tap av biologisk mangfold. Prosjektene omfatter rene bevaringsprosjekter, restaurering, bekjempelse av fremmede arter, tilrettelegging for lokal befolkning og integrering av natur og kultur. Det er lagt hovedvekt på å presentere oppnådde resultater. De deltagende kommunene i prosjektet har vært Holstebro (D), Hedensted (D), Kolding (D), Herning (D), Hammerfest (N), Stjørdal (N), Trondheim (N), Ørebro (S), Vanda (FI), Borgå (FI), Akureyri (I), Alftanes (I), Runavik (F/E) og Nes (F/E).

De deltagende kommunene gir også noen rekommandasjoner for hva som skal til for å lykkes med lokale prosjekter.

Rapporten viser at lokalt engasjement og gjennomføring at konkrete lokale prosjekter er et svært viktig bidrag for å nå internasjonale mål som 2010 målet på biodiversitet.

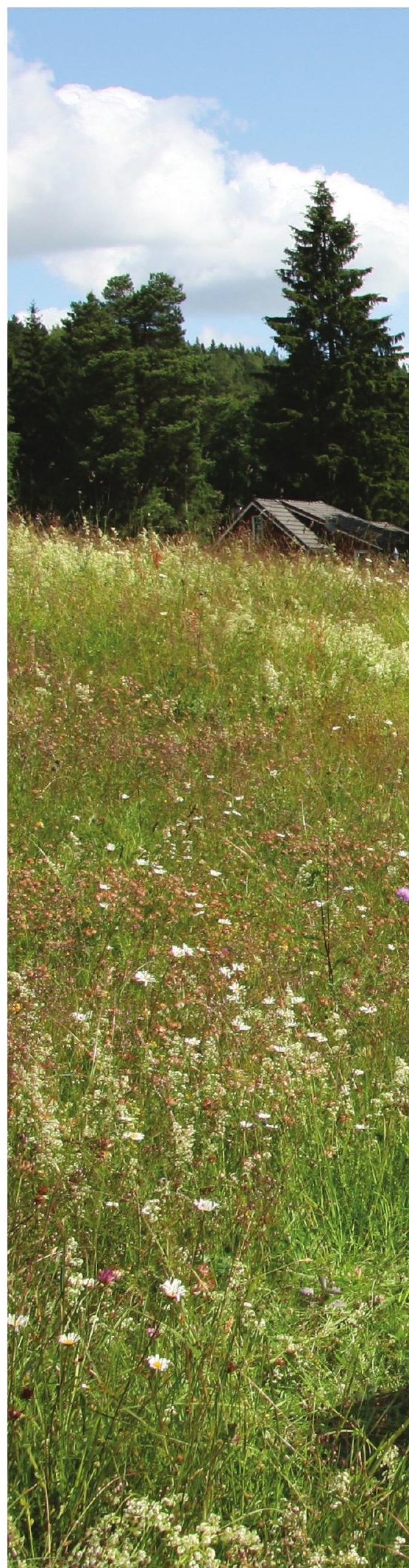

